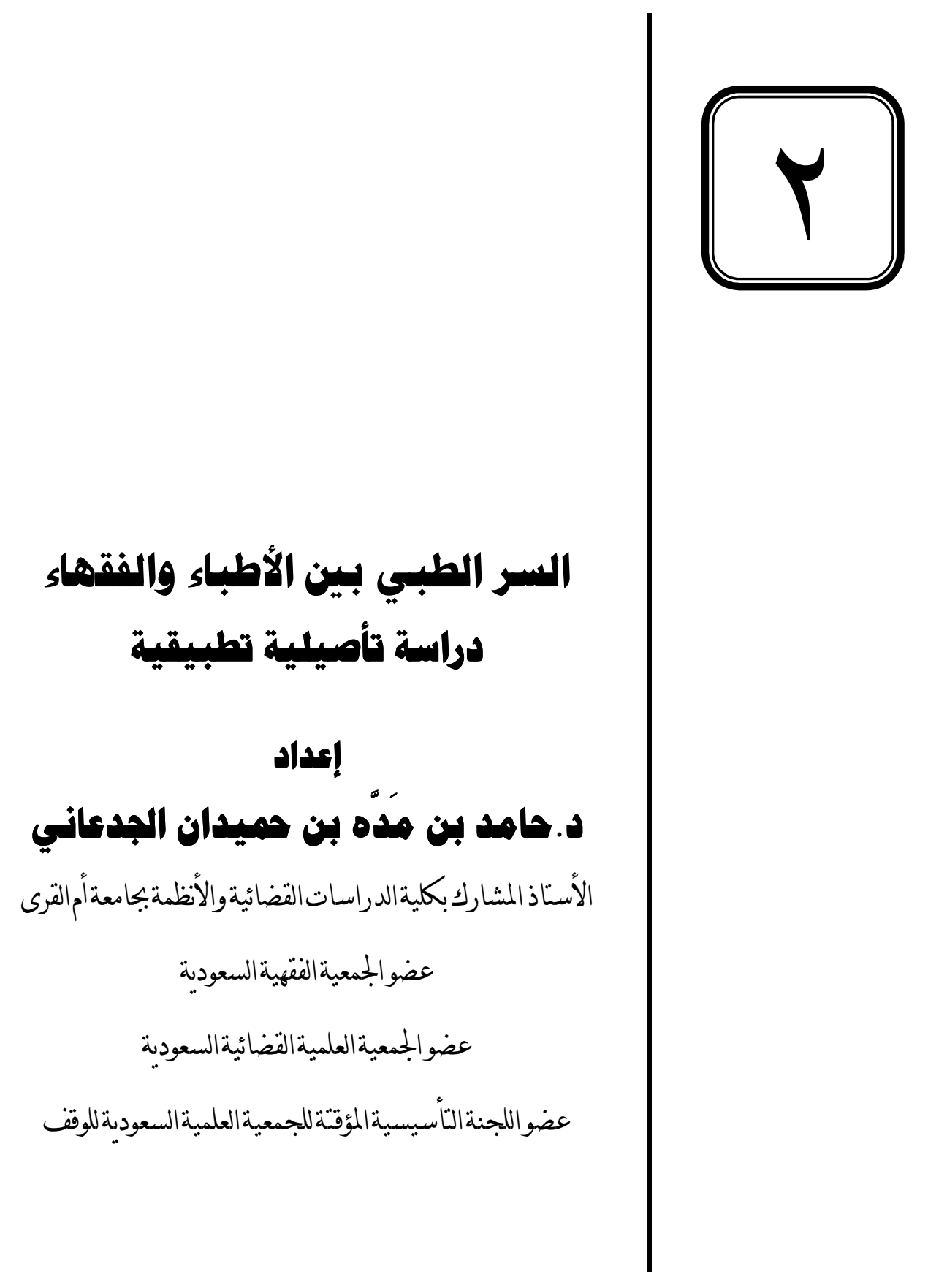




\section{شكر وثناء}

أتقدم بوافر الشكر والتقدير بلحامعة أم القرى بمكة المكرمة ممثلة في عمادة البحث العلمي المدي

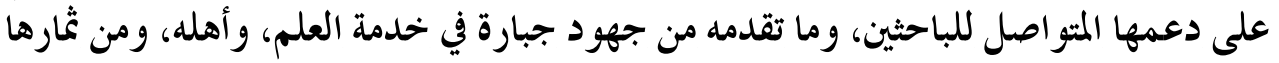

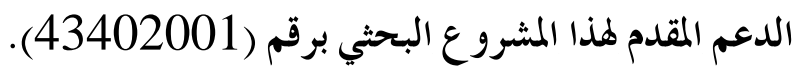

Acknowledgements: The authors would like to Deanship of Scientific Research at Umm AL- Qura University (project\# 43402001) for the financial support

$$
\begin{aligned}
& \text { الباحث } \\
& \text { د. حامد بن مَدَّه بن حميدان الجحدعاني } \\
& \text { الأستاذ المشارك بقسم الدراس باست الدات القضائية } \\
& \text { كلية الدراسات القضائية والأنظمة }
\end{aligned}
$$

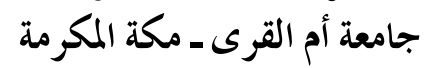




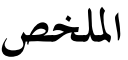

الحمدد الله وحده، و الصحلاة و السلام على من لا نبي بعده . أما بعد:

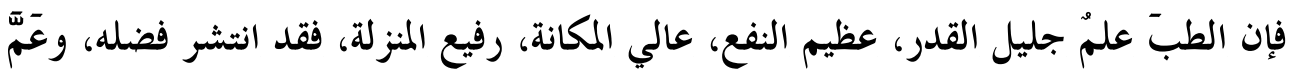

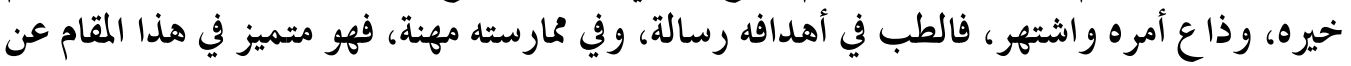

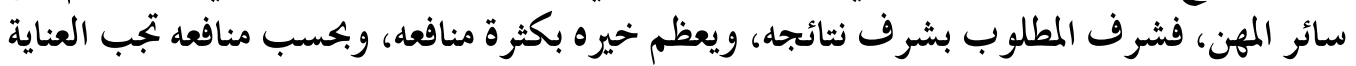

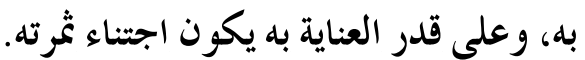

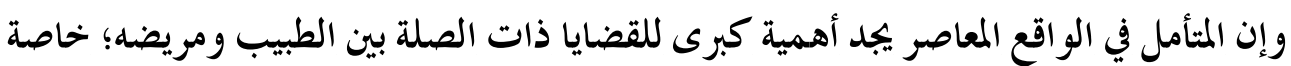

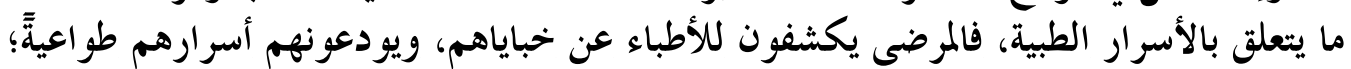

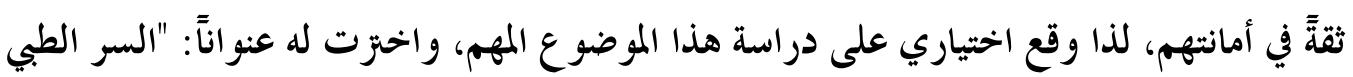
بين الأطباء والفقهاء دراسة تأصيلية تطبيقية"؛ لأن أهم ما يميز مهنة الطب علاقة الطبيب بمريضه،

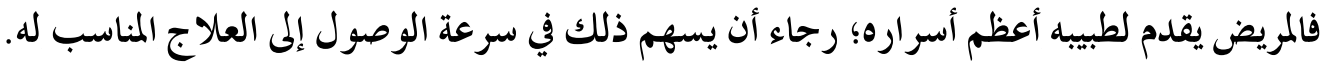

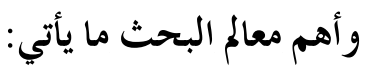

$$
\text { ( ) تعريف السّر الطبي. }
$$

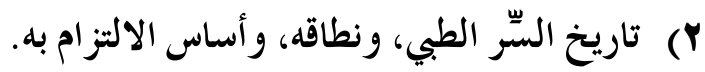

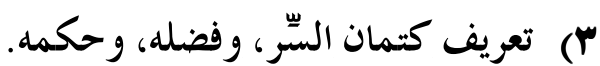
ع) أركان جريمة إفشاء السِّر الطبي. ه) حكم إفشاء الطبيب للسر الطبي. 7) حقوبة الطبيب إذا أفشى السِّر الطبي.

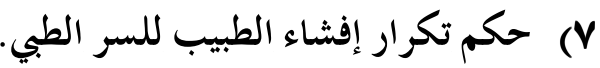
A ) حكم إفشاء أفر اد الطاقم الطبي للسر الطبي. 9) السر الطبي في التقارير والوصفات الطبية. • 1) كيفية إخبار الطبيب المريض بطبيعة مرضه.

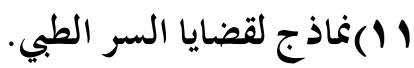

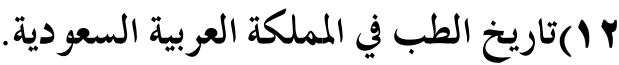

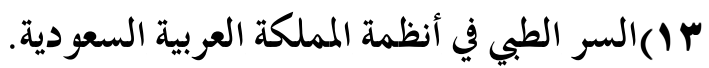

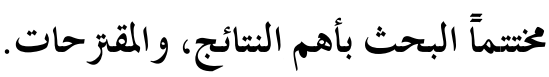
ومن الله تعلى نستمد العون، والتوفيق، والسداد. 


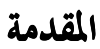

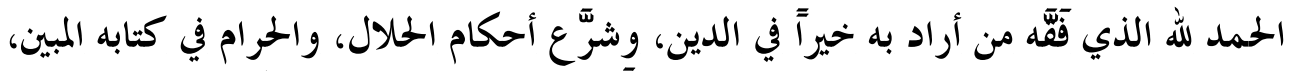

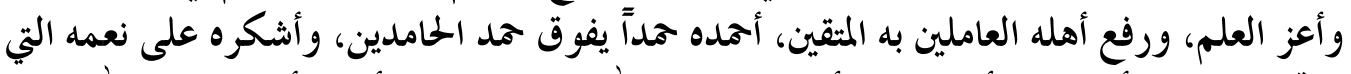

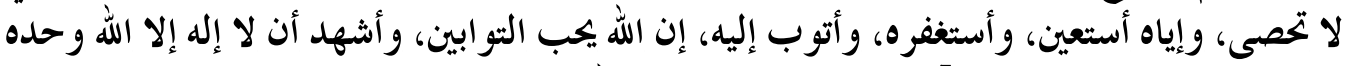

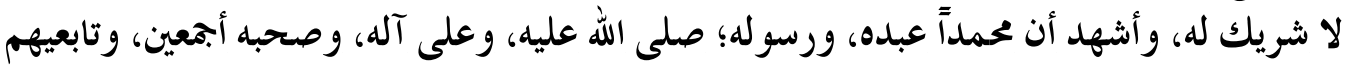

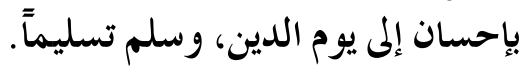

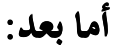

فإن الطبّ علمّ جليل القدر، عظيم النفع، عالي المكانة، رفيع المنزلة، قد انتشر فضله، وعََّّ

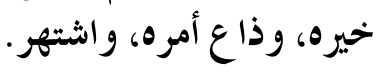

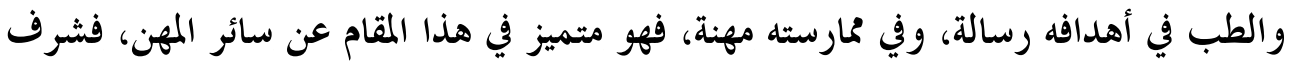

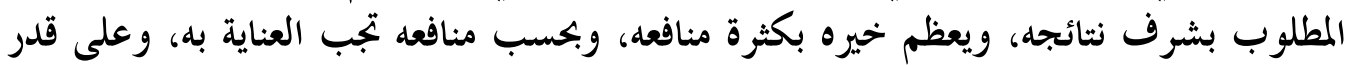

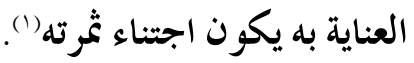

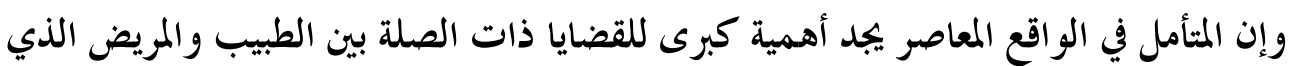

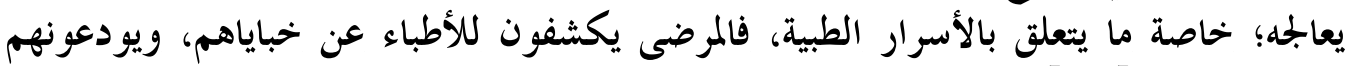

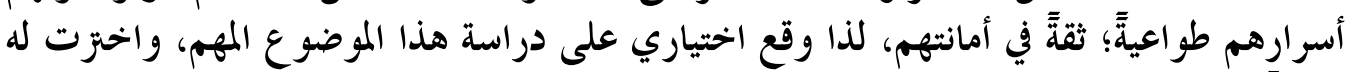

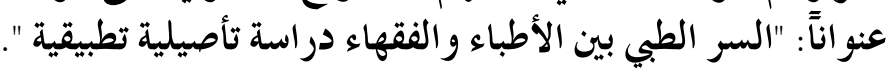

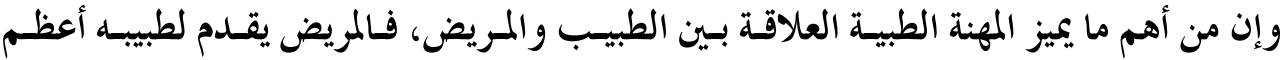

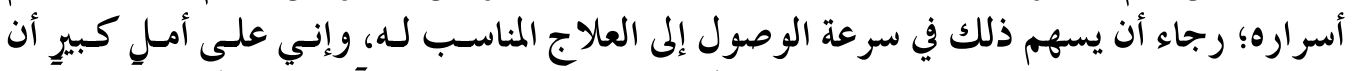

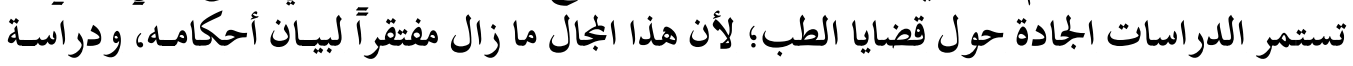

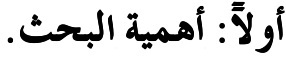

كان لهذا البحث مزايا عديدة، استحوذت على اهتمامي أذكر منها:

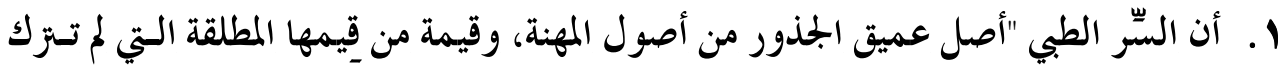

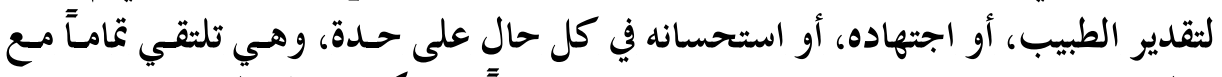

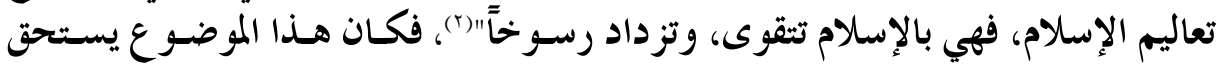
الدراسة، و البحث الجحاد؛ لبيان أحكامه.

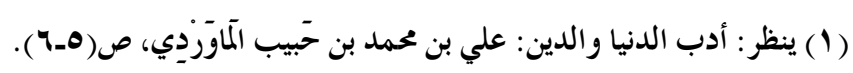

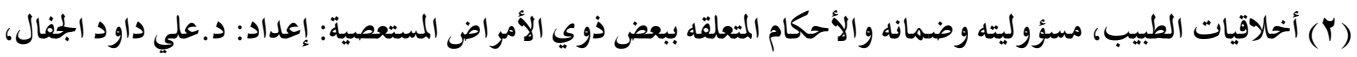

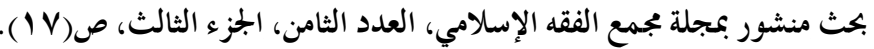




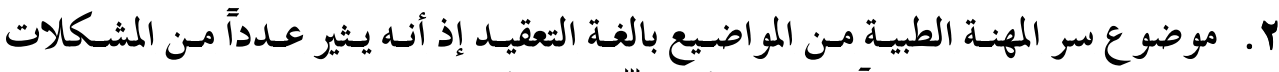

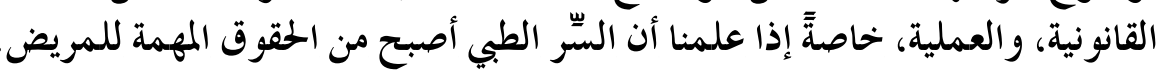

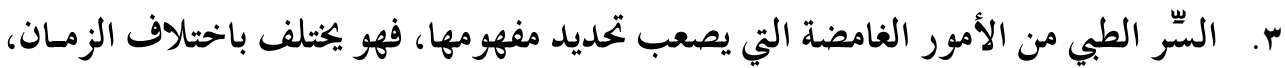

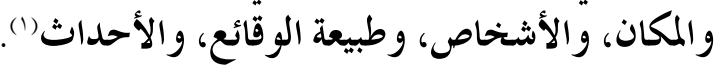
ع. أن كَثيرًا من الوقائع التي تحدث أثناء الممارسات الطبية اليومية تكون نتيجة الجهـل الكامـل

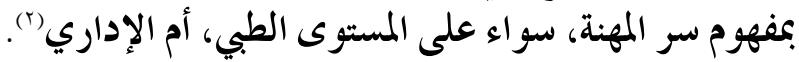

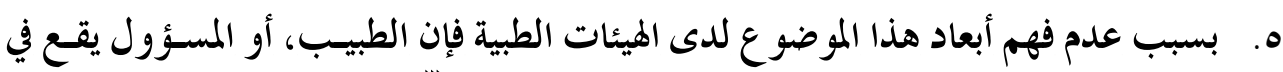

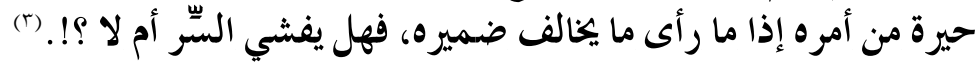

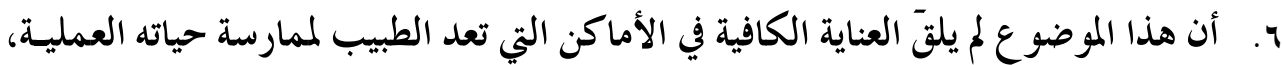

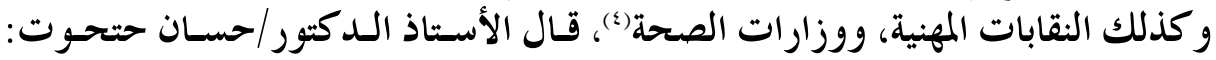

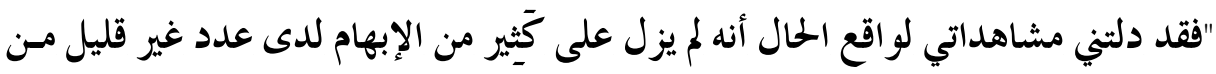
أبناء المهنة"(•) ثانياً: أهداف البحث. أهم أهداف البحث ما يأتي: I ـ بيان سعة الثريعة الإسلامية، ويسرها، ورحابة أفقها. ץ . إيجاد الحلول الشرعية لكثير من المسائل الشائكة في مسائل السر الطبي. r. يدخل البحث في نطاق كشف اللثام عن أحكام المكلفين المتعلقة بالطب، وممارسته، وما

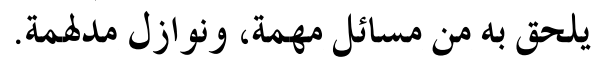

(1 ) ينظر : السِّر الطبي: د.عبد السلام التزمانيني، بحـث منشسور بمجلـة الحقـوق والشـريعة، السـنة الخامسـة، العـدد الثـاني، ص) ( • ( ) (Y) ينظر : مجلة مجمع الفقه الإسلامي، العدد الثامن، الجزء الثالث، ص(بV).

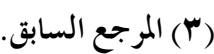
( ) ينظر : سر المهنة بين الكتمان والعلانية: إعداد: د. أحمد رجائي الجندي، بحث منشور بمجلة مجمـع الفقـه الإسـلامي،العدد

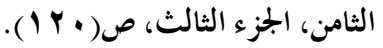

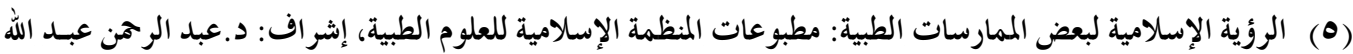

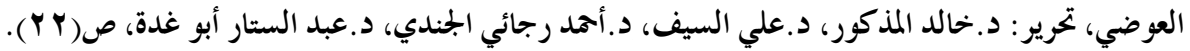




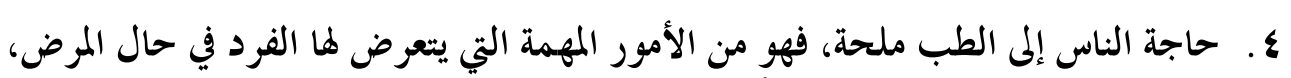
فبيان الأحكام المتعلقة به، أمر غايةٌ في الأهمية. ه. تجميع أحكام (السر الطبي) في ملزمة واحدة، فيه تسهيل للباحثين، وتقريب للمنقبين عن أحكامه.

7 . . خحدمة الفقه الإسلامي بإثراء الموضوع، والإسهام في إبراز مزاياه، و كيفية معالجته للقضايا

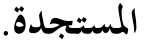
ثالثاً: أسباب اختيار موضوع البحث. من أهم أسباب اختيار موضوع البحث ما يأتي:

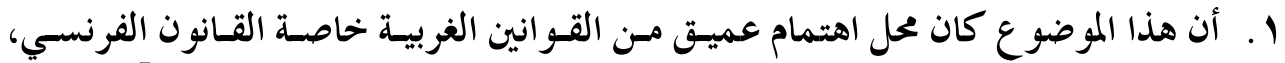

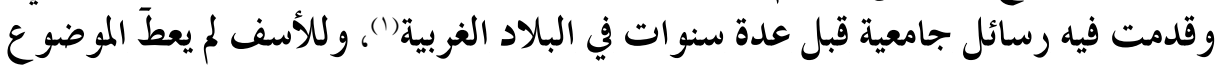
حقه في البلاد الإسلامية.

Y. . الرغبة في بحث المسائل المستجدة في الجال الطبي؛ لأهميتها في حياة الناس بكافة أطيافهم.

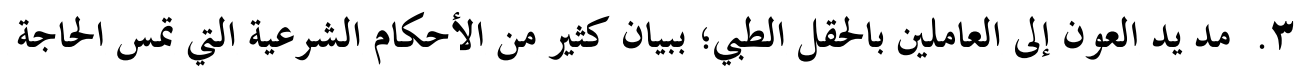

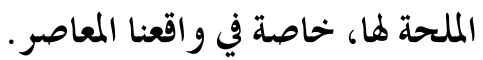
ع. يكثر التنازع حول موضوع (السر الطبي)، وتنتشر أخباره في الصحف اليومية، فلا بد من إيضاح أحكامه. رابعاً: مشكلة البحث.

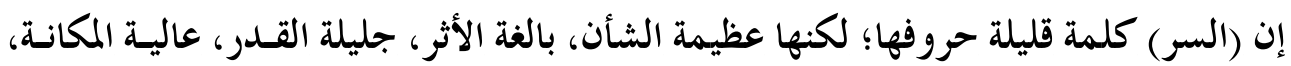

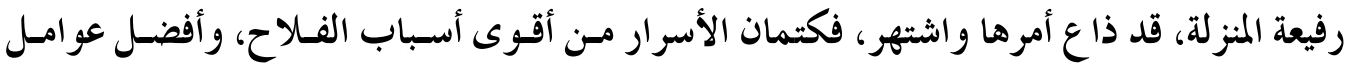

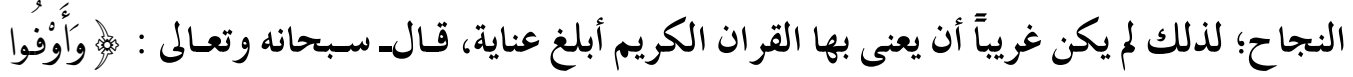
(r)

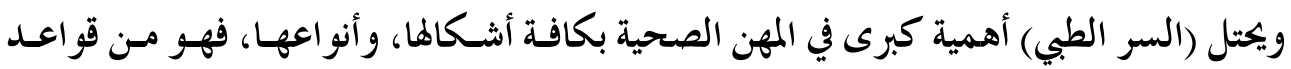

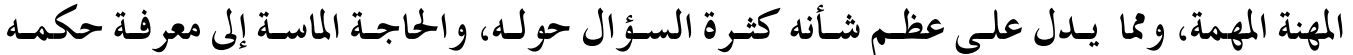

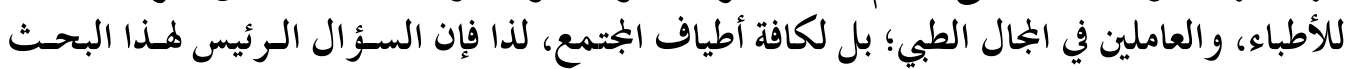
هو : (ما حكم إفشاء السر الطبي؟) في الجمال الطب؟

(1) ينظر : المسؤولية الجز ائية للأطباء عن إفشاء السِّر المهني: موفق علي عبيد، ص(7). $-\wedge r \varepsilon-$ 


$$
\text { خامساً: تساؤلات البحث. }
$$

تتفرع العديد من الأسئلة من التساؤل الرئيس للبحث، ومن ذلك البك ما يأتي:

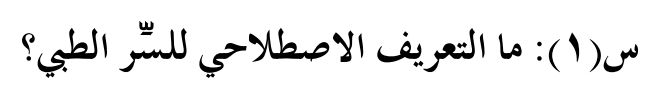

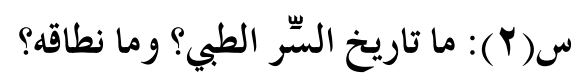

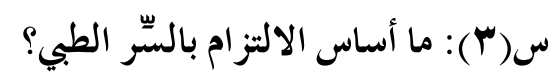

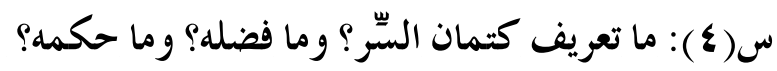
س(ه): ما أر كان جريمة إفشاء السّر الطبي؟

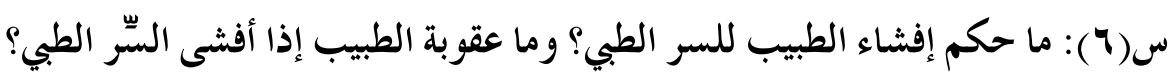

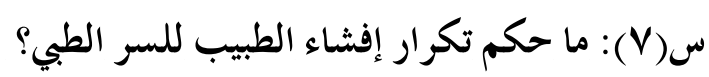

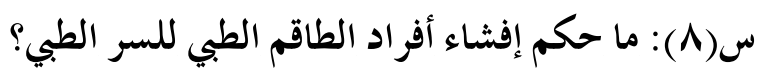

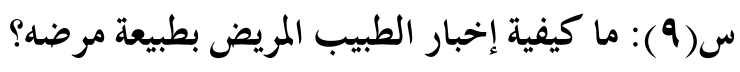

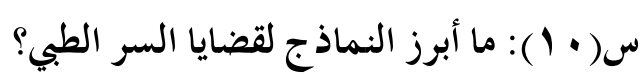

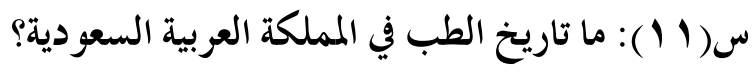

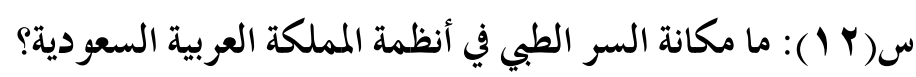
سادساً: الدراسات السابقة المختارة.

العلم أمانة عظيمة، ومسؤولية جليلة كريمة، تُبلغ بها رسـالة الله تعالم، وتُقـام بها الحجـة على

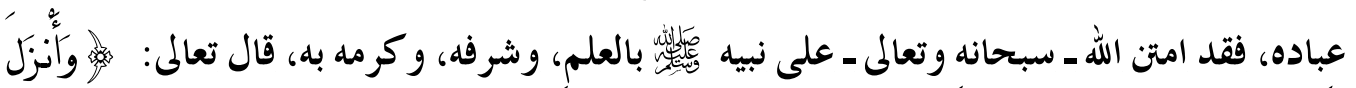

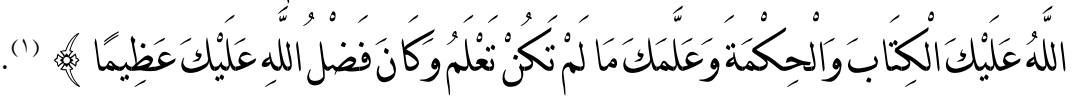

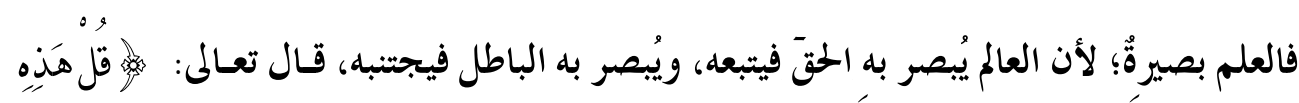

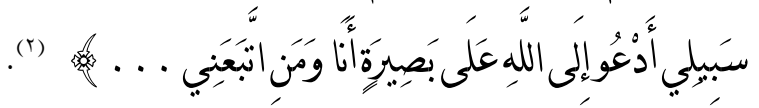

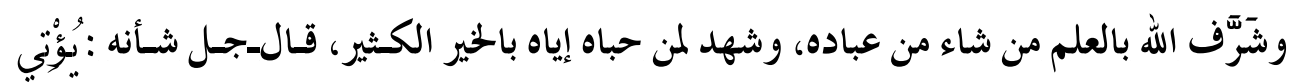

$$
\begin{aligned}
& \text { (1) سورة النساء، الآية (1) (1). } \\
& \text { (†) سورة الأنعام، الآية (OV). }
\end{aligned}
$$




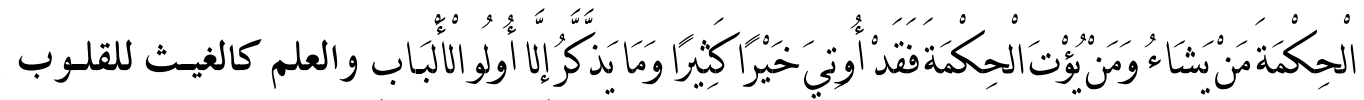

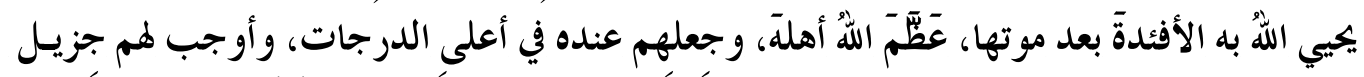

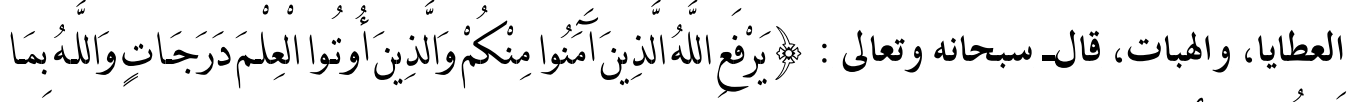

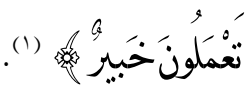

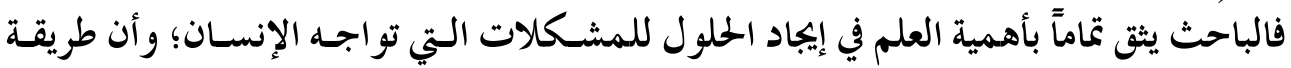

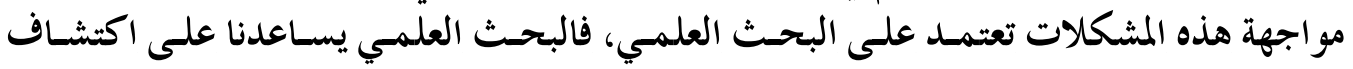
المثكلات، وتنظيم الأولويات، وإيجاد الحلول المعند المناسبة لها. ويحتاج الباحث إلى الـنفكير العلمسي في مواجهـة مشـكلات مجتمعسه؛ لأنسه يتعـرض للكـثير مـن

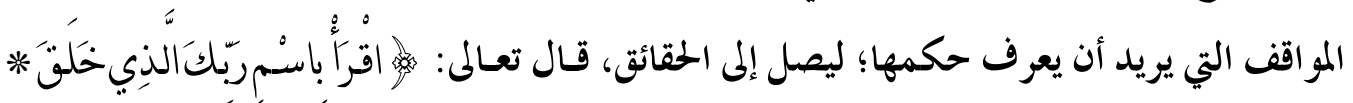

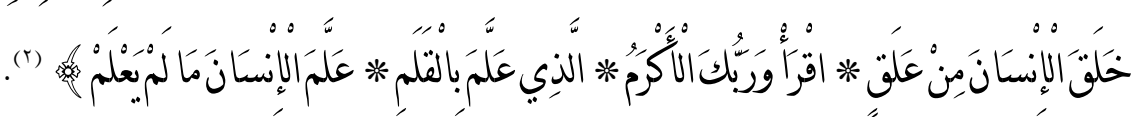

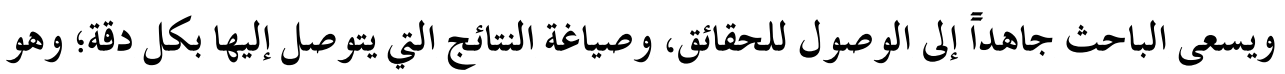

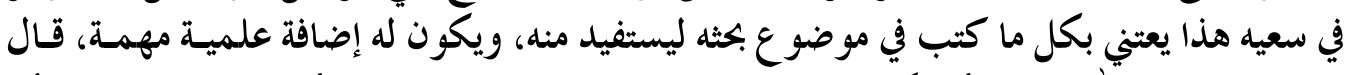

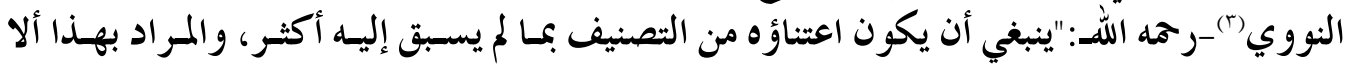

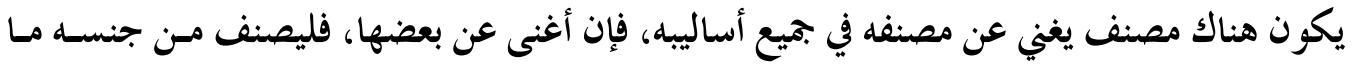

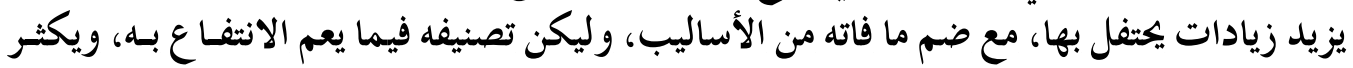

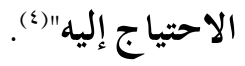

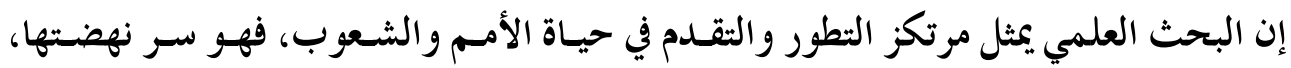

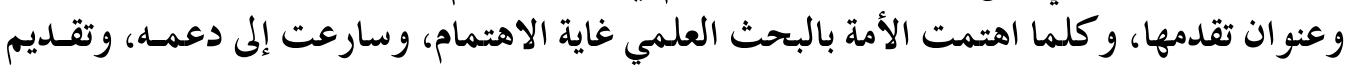

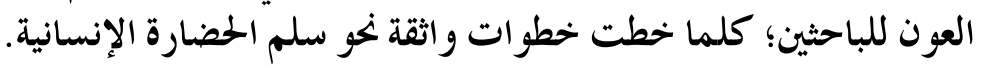

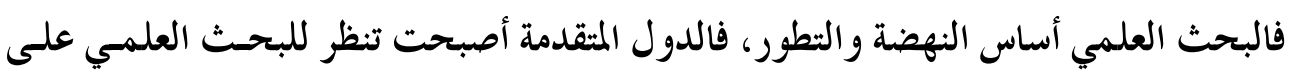

$$
\text { (1) (1) سورة الجادلة، الآية (1) سورة العلق، الآيات (1). }
$$

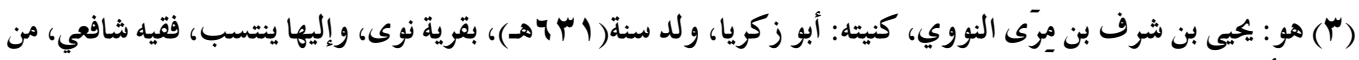

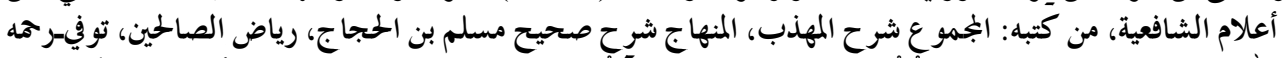

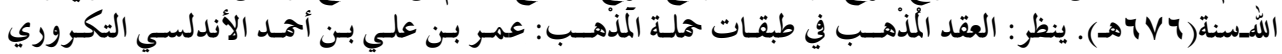

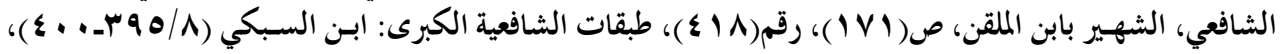

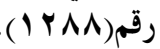

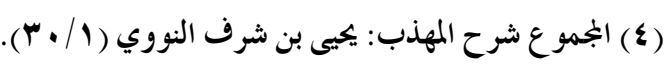




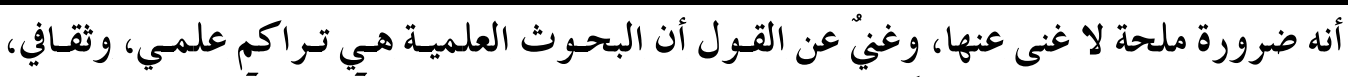

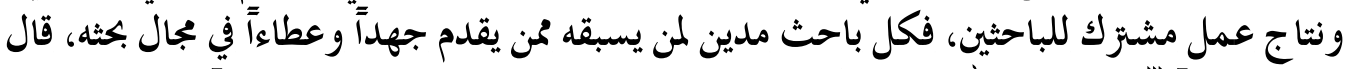

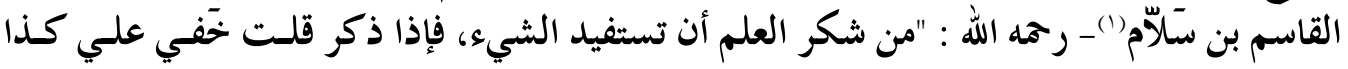
و كذا، ولم يكن لي به علم حتى أفادني فلان فيه كذا و كذا، فهذا شكر العلم"(().

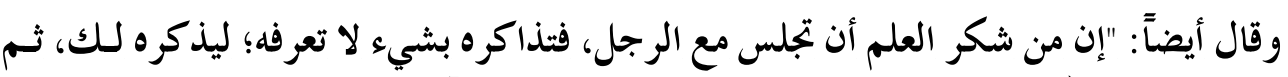

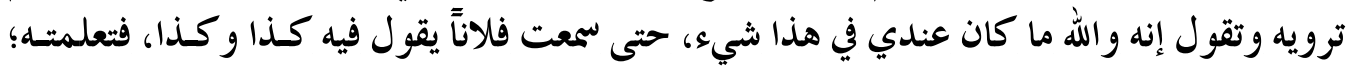
فإذا فعلت ذلك فقد شكرت العلم" (r).

و من خلال البحث والاستقراء المبني على المطالعة فيما كتبه الباحثون حول (السر الطبي)، وبناء

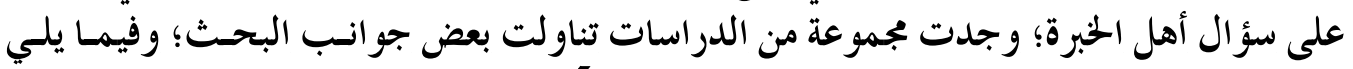

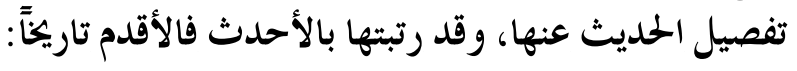

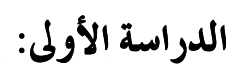
ا ـ عنوان الكتاب: (إفشاء الأسرار وأحكامه في الفقه الإسلامي). Y. . المؤلف: محمد بن أحمد بن واصل. ب. الناشر: دار طيبة للنشر والتوزيع. ع ـ مدينة النشر : الرياض، المملكة العربية السعودية.

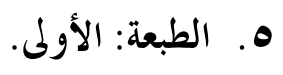

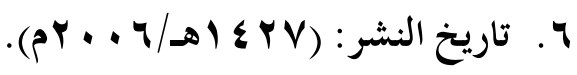

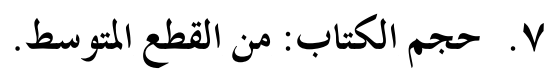

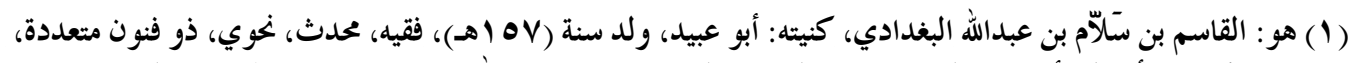

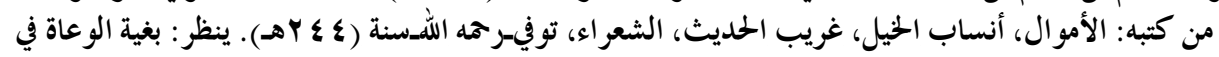

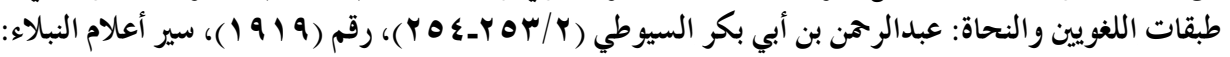

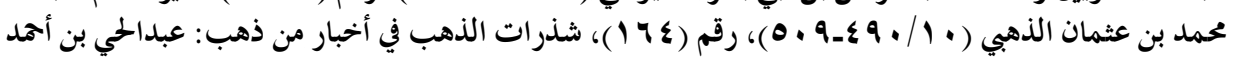

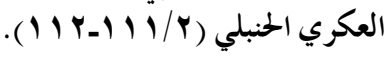

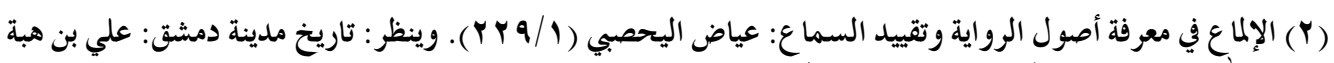

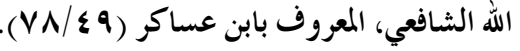

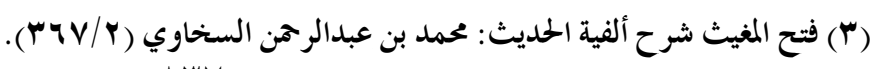
- NTV _ 


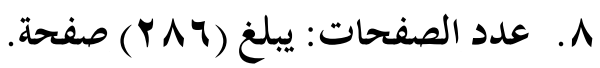

محتوى الدراسة:

اشتملت الدراسة على مقدمة، وتمهيد، وثلاثة فصول، وخحاتمة، على النحو الآتي:

التمهيد: في بيان حقيقة السر، والإفشاء، والألفاظ ذات الصلة بهما.

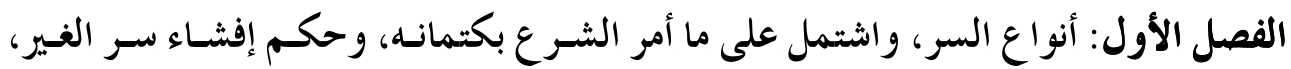

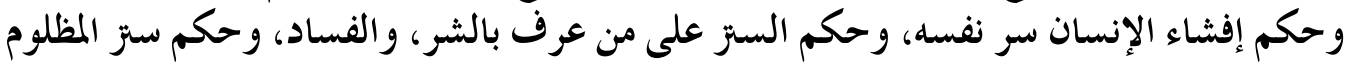

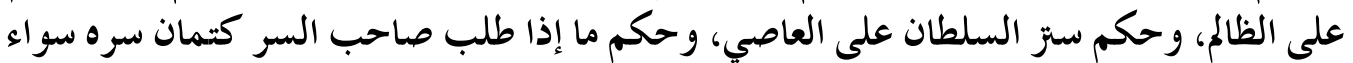

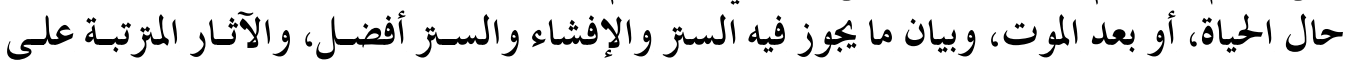

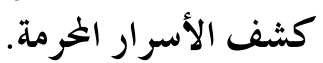

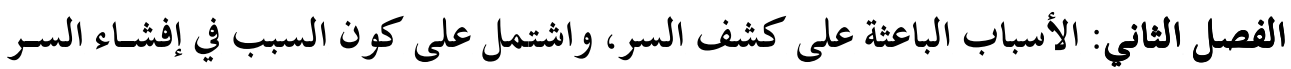

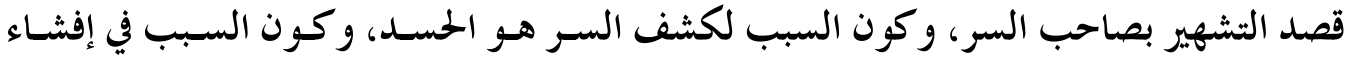

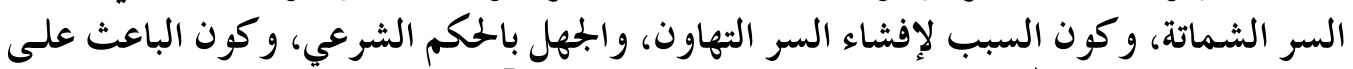

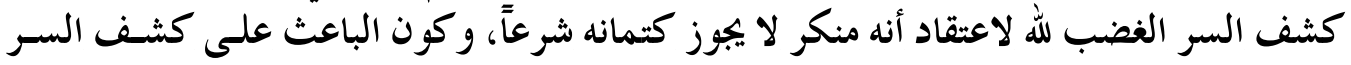

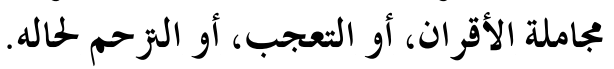

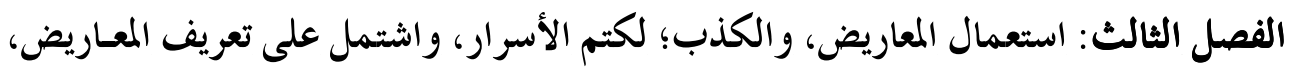

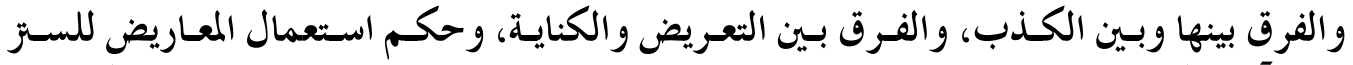

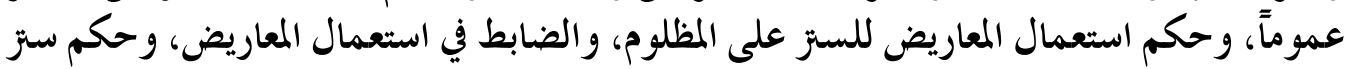

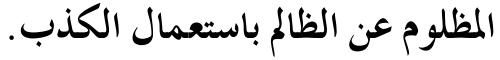

$$
\text { تقويم الدراسة: }
$$

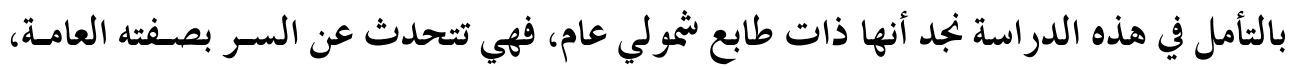

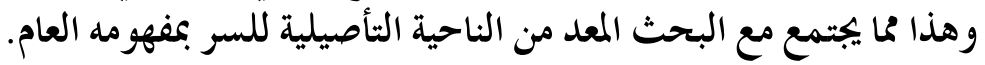

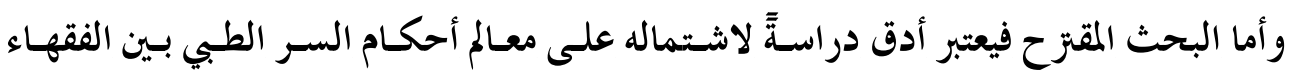

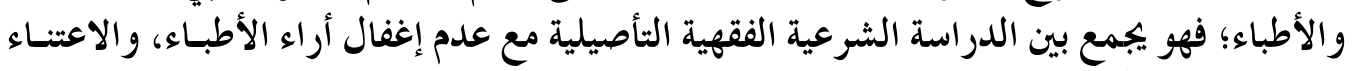
بها، ويتناول بشكل أعمت:

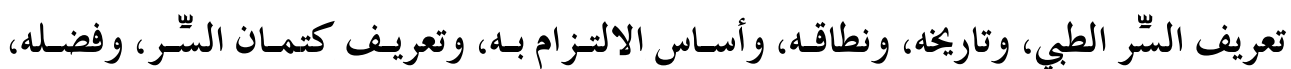

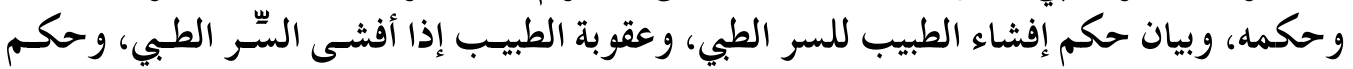

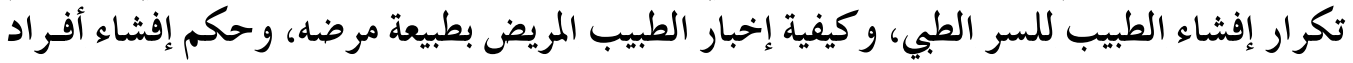

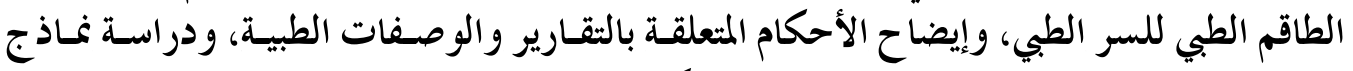

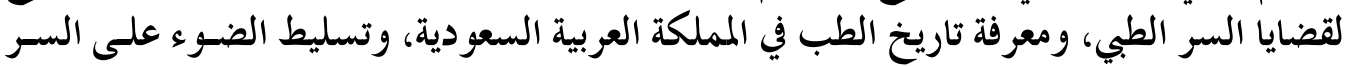
الطبي في أنظمة المملكة العربية السعودية. 


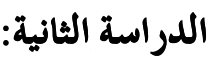

ا ـ عنو ان الكتاب: (أبحاث اجتهادية في الفقه الطبي). Y ب المؤلف: د.محمد بن سليمان الأشقر.

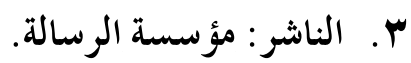
ع. ملدينة النشر: بيروت_لبنان. هـ الطبعة: الأولى.

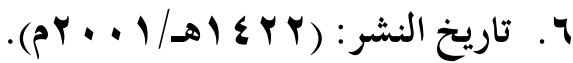
V V . حجم الكتاب: من القطع المتوسط. A. عدد الصفحات: يبلغ (YVq ) صفحة. محتوى الدراسة: اشتملت الدراسة على مقدمة، ومجموعة من الأبحاث المتنوعة، وخاتمة، على النحو الآتي:

$$
\begin{aligned}
& \text { I. الاستنسا خ في ميزان الشريعة الإسلامية. } \\
& \text { Y. الأمومة ومرض الإيدز. }
\end{aligned}
$$

r. إفشاء السر وأحكامه في الشريعة الإسلامية وتطبيقاتها في مجال عمل الطبيب، وشمل الأمور التالية:

$$
\text { متميل الأسرار. }
$$


نماذج من أحكام إفشاء السر في المهنة الطبية.

ع. بداية الحياة الإنسانية ونهايتها.

๑. المو اد الخرمة و النجسة، و استعمالاتها في الغذاء و الدواء.

7. . نقل وزر اعة الأعضاء التناسلية.

V V . الذبائح و الطرق الشرعية في إنجاز الذكاة.

1. مدى الاحتجاج بالأحاديث النبوية في الشؤون الطبية و العلاجية.

9 ـ . اثبات النسب بالبصمة الوراثية.

تقويم الدراسة:

لا يجتمع البحث المعد مع هذا الكتاب إلا في دراسة واحدة المعنون لها: (إفشـاء السـر وأحكامـهـ

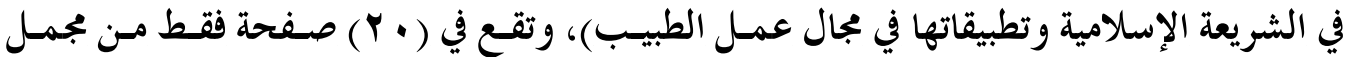

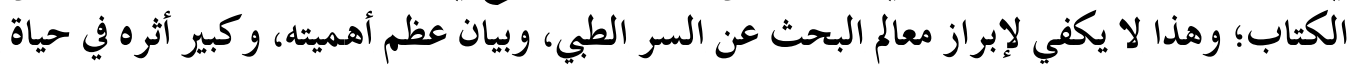

الطبيب العملية.

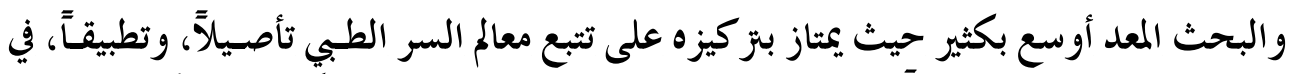

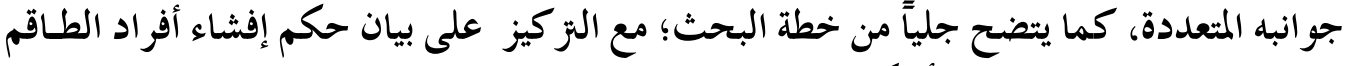

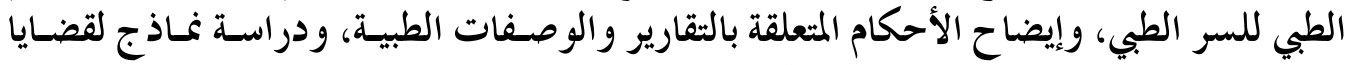

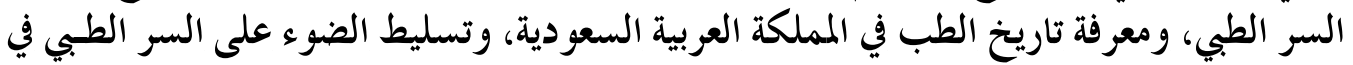

أنظمة المملثكة العربية السعودية.

الدراسة الثالثة: - الث

1. عنو ان الكتاب: (كتمان السر وإفشاؤه في الفقه الإسلامي).

r ـ المؤلف: شريف بن أدول بن إدريس.

r. الناشر: دار النفائس.

ع. ـ مدينة النشر :عمان_الأردن.

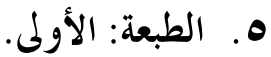




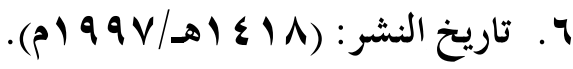

$$
\begin{aligned}
& \text { V. . حجم الكتاب: من القطع المتوسط. }
\end{aligned}
$$

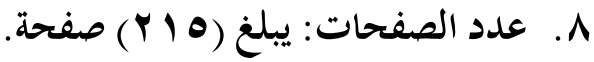

$$
\begin{aligned}
& \text { محتوى الدراسة: }
\end{aligned}
$$

اشتملت الدراسة على مقدمة، وخمسة فصول، وخاتمة، على النحو الآتي:

الفصل الأول: في مفهوم السر والألفاظ ذات الصلة، و اشتمل على مفهـوم السـر، و الكتمـان،

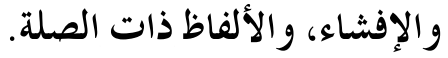

الفصل الثاني: في أنواع الأسرار، واشتمل على الأسرار الفردية، والأسرار الزوجية، والأسرار

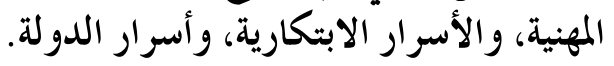

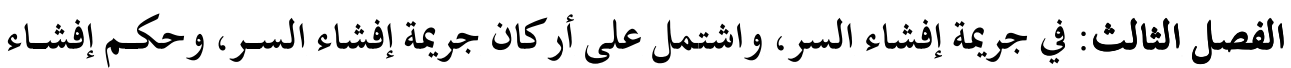
السر، وأهمية كتمانه.

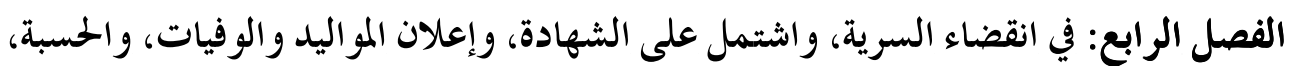

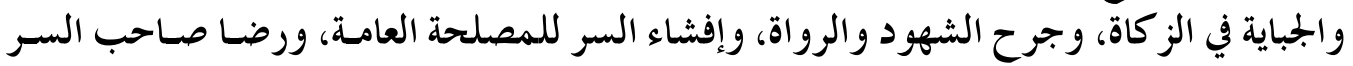

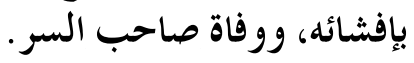

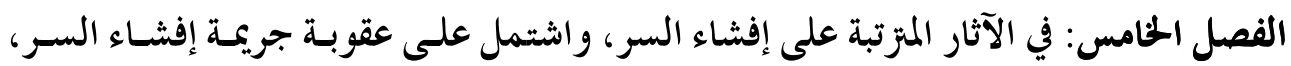

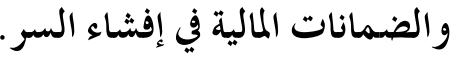

\section{تقويم الدراسة:}

تتطرق هذه الدراسة إلى السر بمفهو مه العام، ولم تتحدث عن السر الطبي إلا في خـس صـفحات

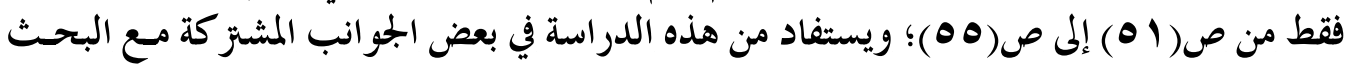

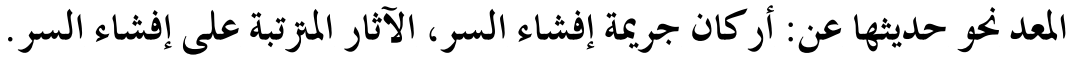

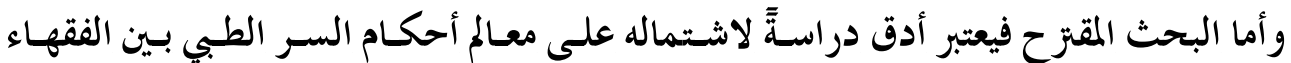

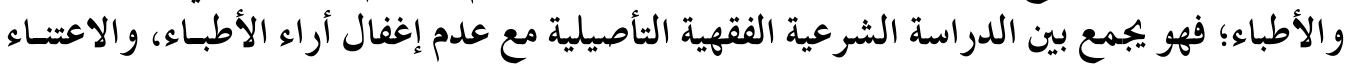

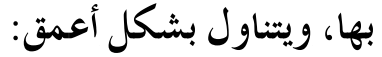

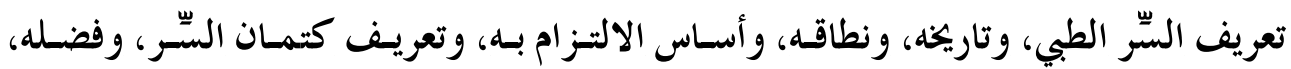

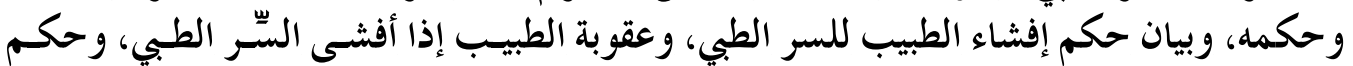

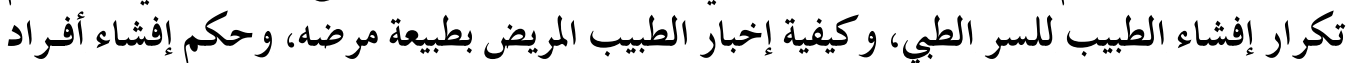

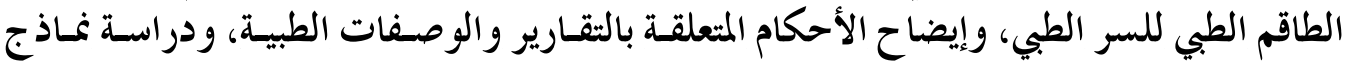




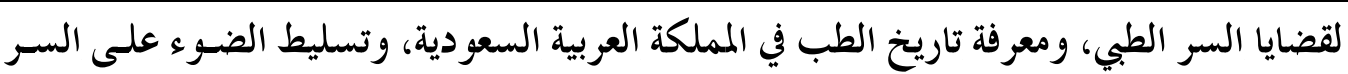
الطبي في أنظمة المُملكة العربية السعودية. سابعاً: المنهج المتبع في كتابة البحث، وإجر اءاته.

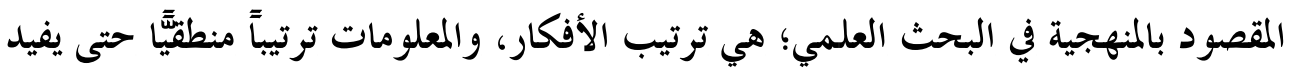

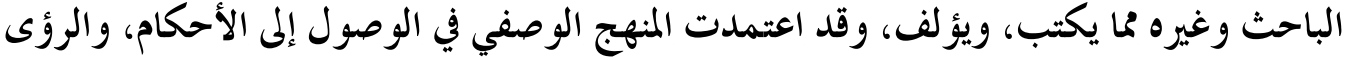
التي يتبناها الباحث (1) (ل)

\section{وسوف أتبع في كثابة هذا البحث القواعد العلمية المتعارف عليها، وفيما يأتي أهم معالمها:}

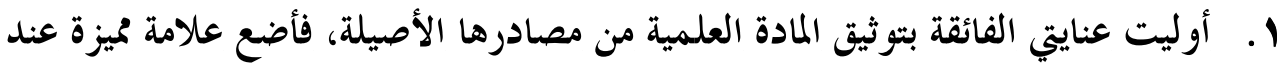

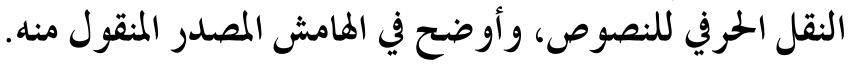

$$
\text { Y. . عند ذكر الآيات القر آنية الكريمة، أو جزء منها، فإني أذكر اسم السورة، ورقم الآية. }
$$

r. عند ذكر الأحاديث النبوية الشريفة، أو الآثار الكريمة، فإني أقوم بتخريجها وفق القواعد

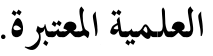

ع. عند ورود بعض الكلمات المشكلة في البحث، فإني أقوم بضبط الكلمة المشكلة؛ حتى لا يقع القارئ الكريم في اللبس الخيل للمعنى.

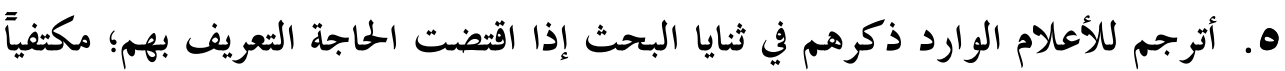

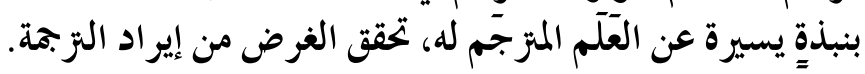

7. . أوليت الهوامش عناية خاصة لما لها من أهمية كبرى في خدمة البحث؛ ولأنها موطن التوثيق العلمي.

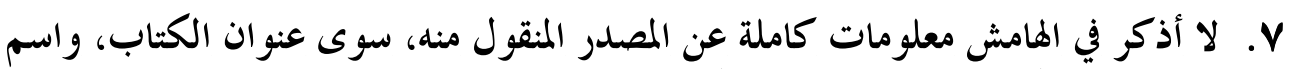

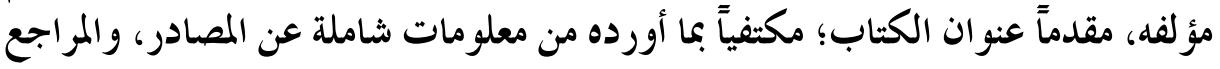

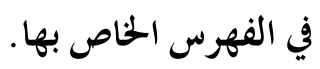
A. إذا شمل الهامش الواحد أكثر من مرجع، فإني أقوم بتزتيب المراجع حسب حروف المعجم. 9. إذا اشتزك العنوان بين كتابين، فإني أذكر اسم المؤلف دائماً منعاً للالتباس. • 1 ـالاهتمام بصحة المكتوب، والاعتناء بخلوه من الأخطاء الُّغوية، والمطبعية، ومراعاة حسن 


$$
\begin{aligned}
& \text { تناسق الكلام، ورقي الأسلوب، وحرصت على حُسن الإخراج الطباعي للبحث، وحسن }
\end{aligned}
$$

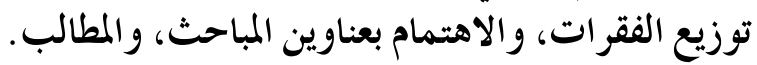

$$
\begin{aligned}
& 1 \text { ا ـ الاعتناء بعلامات التزقيم حتى يكون البحث أقرب إلى الإتقان؛ ليؤدي فائدته المرجوة عند } \\
& \text { قز اءته. - ماء. } \\
& \text { Y I ـ اعتنيت بفهرس المصادر، والمراجع، ورتبته على حروف المعجم. } \\
& \text { ثامناً: خطة البحث. } \\
& \text { اشتمل البحث على مقدمة، وتمهيد، وأربعة فصول، وخاتمة، على النحو الآتي: } \\
& \text { المقدمة: وشثملت الأمور الآتية: } \\
& \text { أهمية البحث. } \\
& \text { أهداف البحث. } \\
& \text { أسباب اختيار موضوع البحدث. } \\
& \text { مشكلة البحث. } \\
& \text { تساؤلات البحث. } \\
& \text { الدراسات السابقة المختارة. } \\
& \text { المنهج المتبع لكتابة البحث، وإجراءاته. } \\
& \text { خطة البحث. } \\
& \text { تمهيد: التعريف بمفردات عنوان البحث. } \\
& \text { وفيه مطلبان: } \\
& \text { المطلب الأول: تعريف الإفشاء. } \\
& \text { وفيه فرعان: } \\
& \text { الفرع الأول: تعريف الإفشاء لفةً. } \\
& \text { الفرع الثاني: تعريف الإفشاء اصطلاحًاً. } \\
& \text { المطلب الثاني: تعريف السّر الطبي. } \\
& \text { وفيه فرعان: } \\
& \text { الفرع الأول: تعريف السّر الطبي باعتبار مفرداته. }
\end{aligned}
$$



وفيه مسألثان:

المسألة الأولى: تعريف السِّر. المسألة الثانية: تعريف الطب.

$$
\text { الفرع الثاني: التعريف الاصطلاحي للسّر الطبي. }
$$

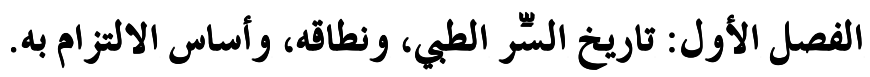

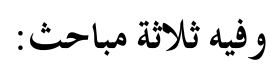

$$
\text { المبحث المبحث الأول: تاريخ الدّرّ الطبي. }
$$

الفصل الثاني: تعريف كتمان السّر، وبيان فضله، وحكمه. وفيه ثلاثة مباحث: الماني: تعريف كئر

$$
\begin{aligned}
& \text { المبحث الأول: تعريف كتمان السِّر. } \\
& \text { المبحث الثاني: فضل كتمان السّرّ. } \\
& \text { المبحث الثالث: حكم كتمان السّّر. } \\
& \text { الفصل الثالث: إفشاء السّر الطبي. } \\
& \text { وفيه تمسة مباحث: }
\end{aligned}
$$

المبحث الأول: أركان جريمة إفشاء السّر الطبي. المبحث الثاني: إفشاء الطبيب للسر الطبي.

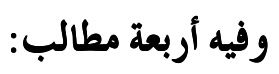

المطلب الأول: حكم إفثاء الطبيب للسر الطبي. المطلب الثاني: عقوبة الطبيب إذا أفشى السّر الطبي. المطلب الثالث: حكم تكرار إفشاء الطبيب للسر الطبي.

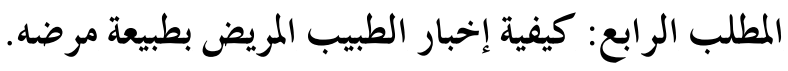

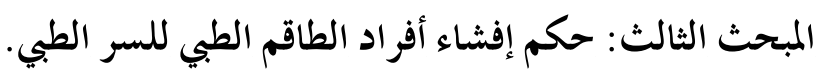
المبحث الرابع: التقارير والوصفات الطبية. 
المبحث الخامس: نماذج لقضايا السر الطبي.

الفصل الرابع: واقع السر الطبي في أنظمة المملكة العربية السعودية.

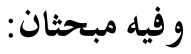

المبحث الأول: تاريخ الطب في المملكة العربية السعودية.

المبحث الثاني:السر الطبي في أنظمة المملكة العربية السعودية.

الماتمة.

وما أبمل ما قاله ابن القيم" - رحه الله : "فيا أيها القارئ له، و الناظر فيه، هذه بضـاعة صـاحبها

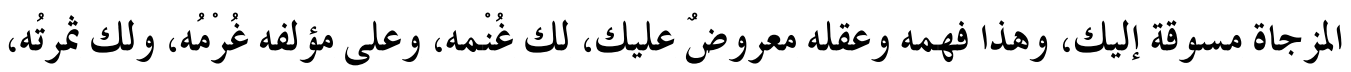

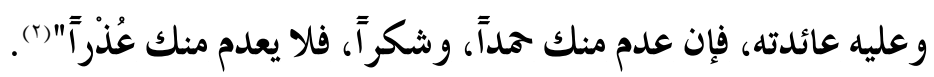

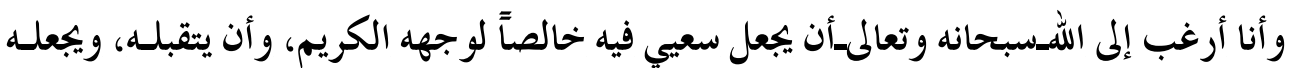

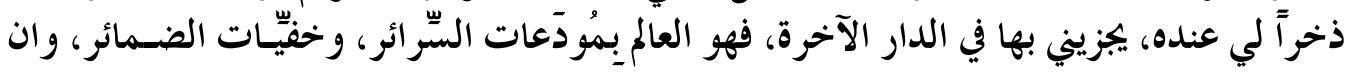

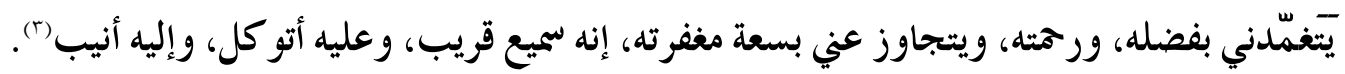

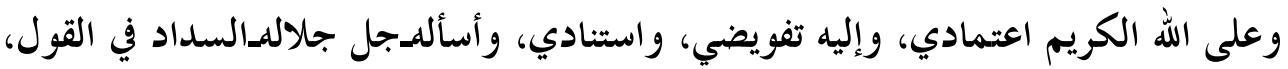

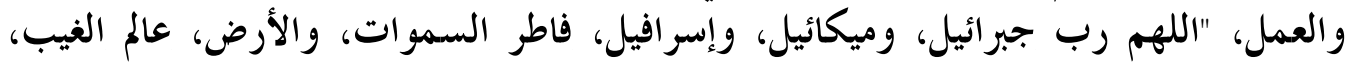

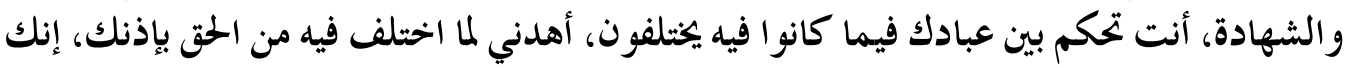

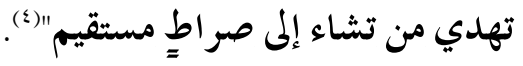
وهذا أوان الشروع في المقصود، ومن اللـجل وعلا_نستمد العون، والتوفيق، والسداد.

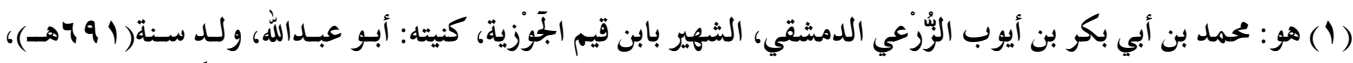

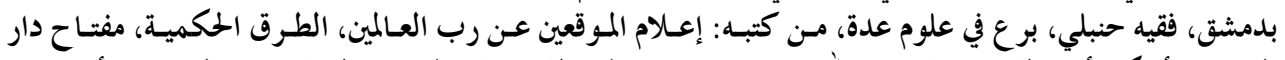

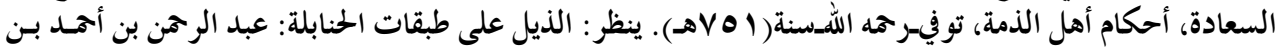

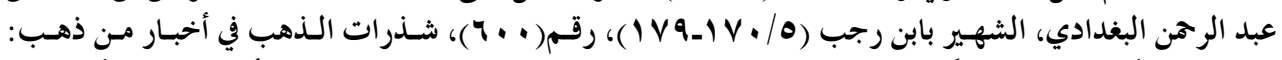

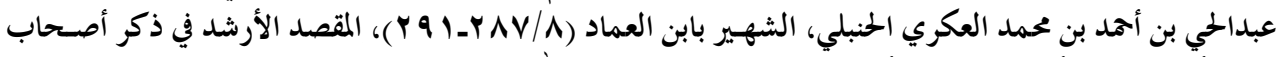

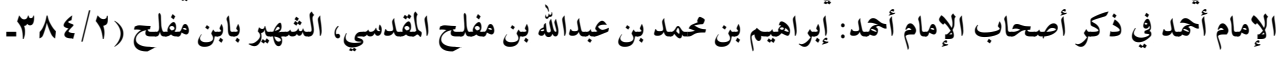

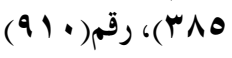

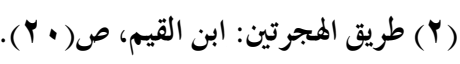

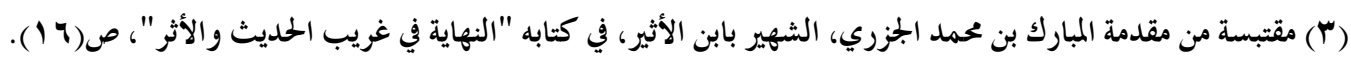

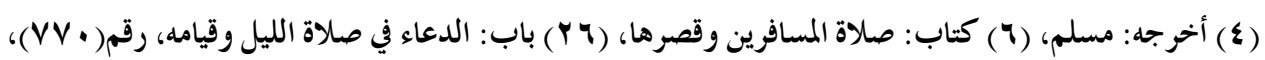
ص) ( 


\section{تمهيد}

التعريف بمفردات عنوان البحث

المطلب الأول: تعريف الإفشاء.

الفرع الأول: تعريف الإفشاء لغةًَ) (1).

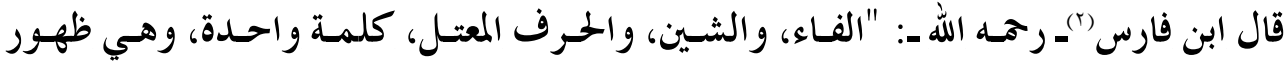
الثيء، يقال: فَشَا الشيء: ظهر "(r).

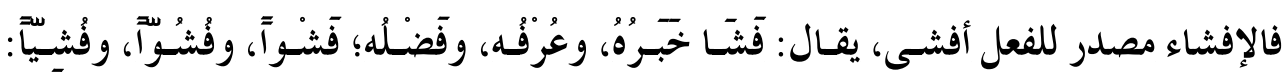

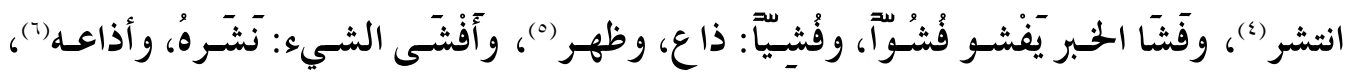

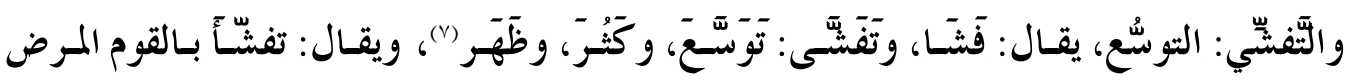

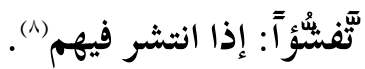

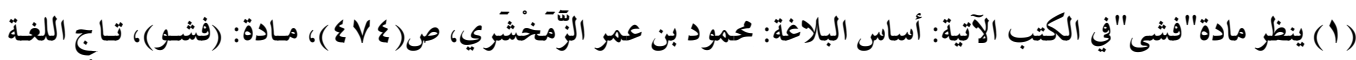

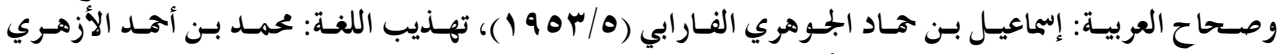

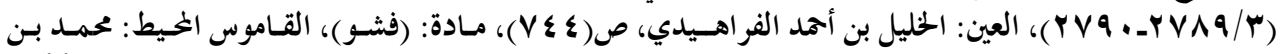

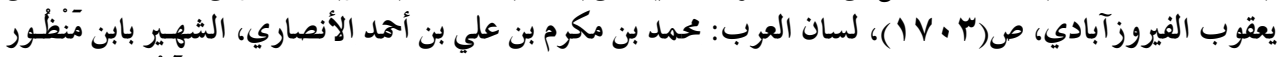

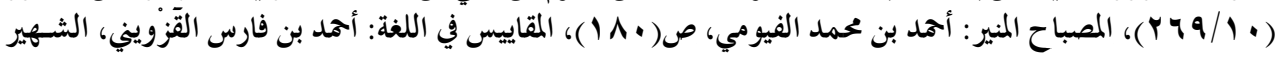

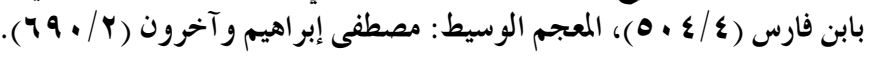

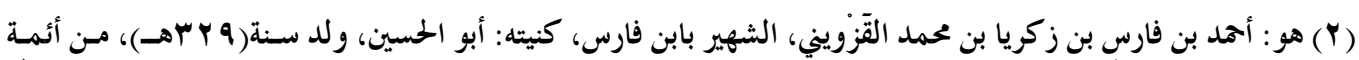

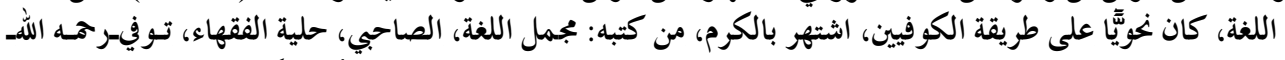

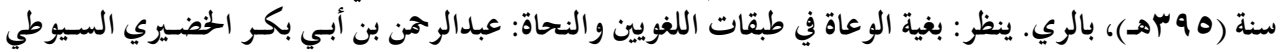

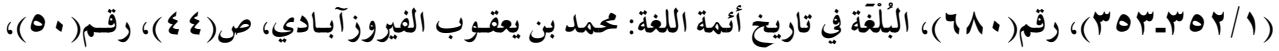

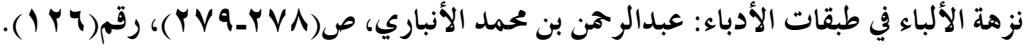

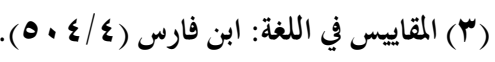

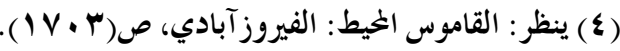

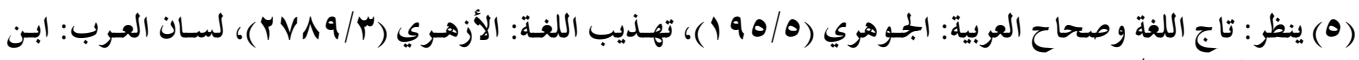

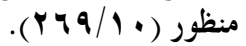

(7) ينظر : المعجم الوسيط: مصطفى إبر اهيم وآخرون (r/ • 79).

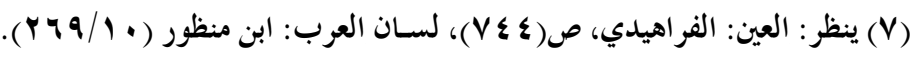

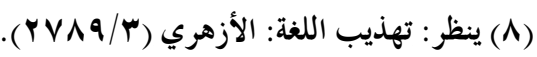




$$
\text { والإفشاء كثرة الإظهار (1). }
$$

فالمر اد بإفشاء السِّر هو : ظهوره، و وانتشاره(ب).

\section{الفرع الثاني: تعريف الإفشاء اصطلاحاً.}

لا يخرج معنى الإفشاء في اصطلاح الفقهاء عن معناه اللغوي"(r).

فيُعرف الإفشاء بأنه: "الإظهار في أزمنة، وأمكنة متعددة" (؛).

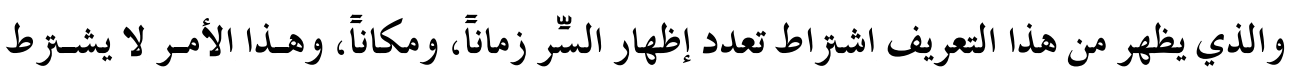

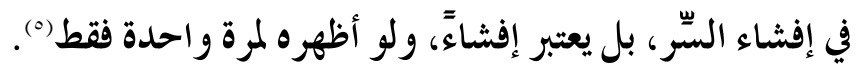

فلو عُرِفَ الإفشاء بأنه: "الإظهار، والنشر "؛ لكان أولى، فيكون التعريف بدون تقييد.

المطلب الثاني: تعريف السِّر الطبي.

الفرع الأول: تعريف السِّر الطبي باعتبار مفرداته المئ.

$$
\begin{aligned}
& \text { المسألة الأولى: تعريف السِّ . } \\
& \text { أولاً: تعريف السِّر لفةّ(ج). }
\end{aligned}
$$

تدور كلمة السر في معناها اللغوي حول إخفاء الشيء، وعدم إظهاره، قال ابن فارس-رحمه الله:

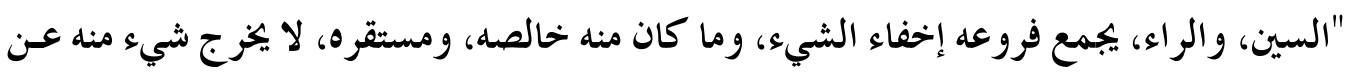

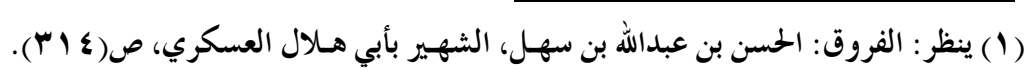

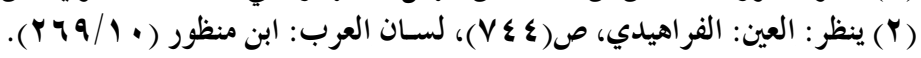

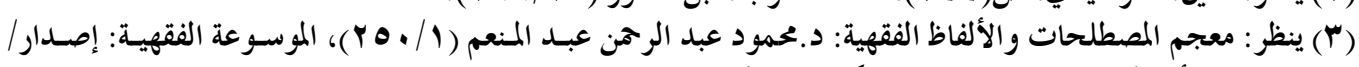

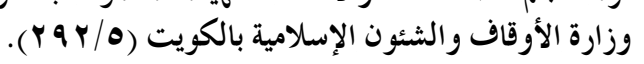

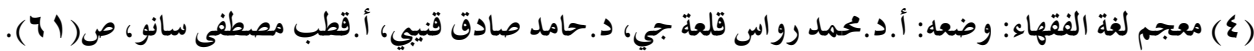

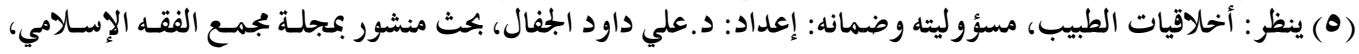

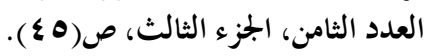

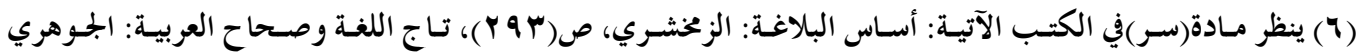

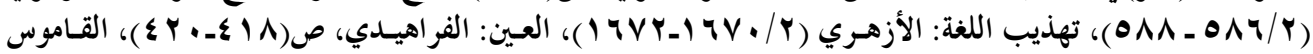

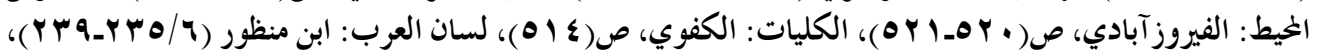

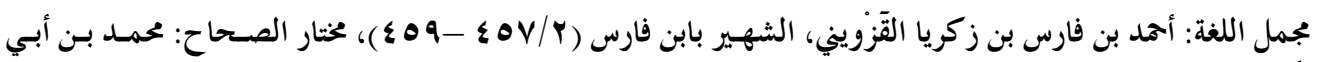

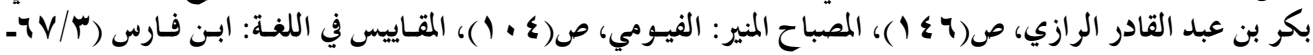

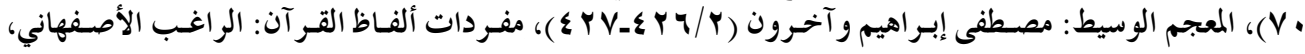




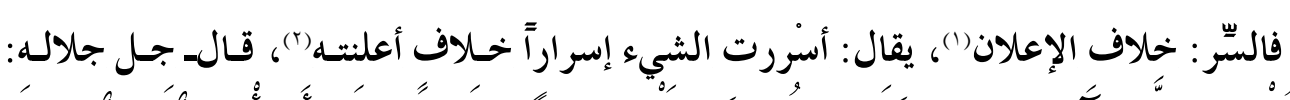

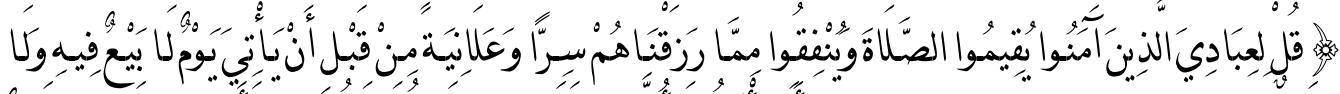

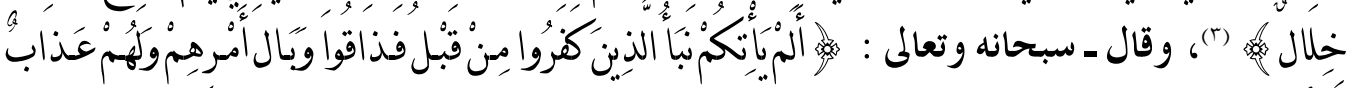

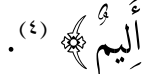

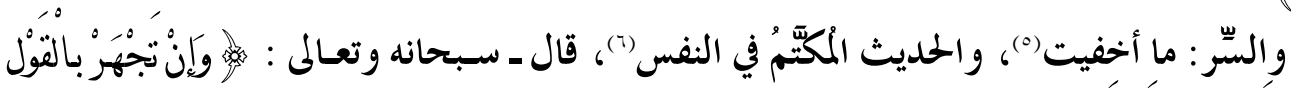

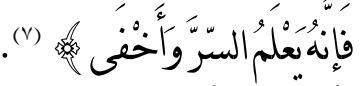

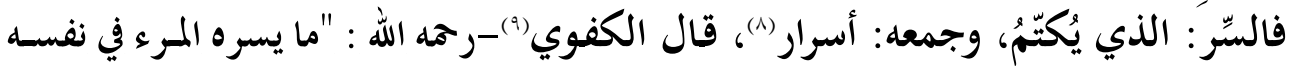

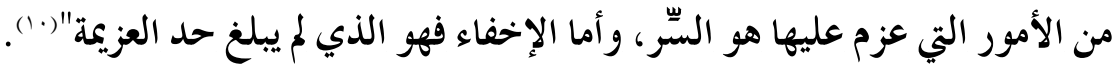

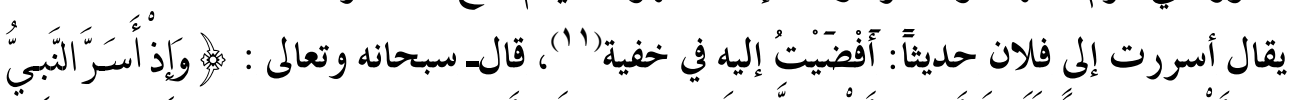

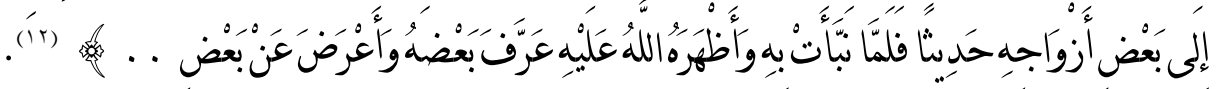

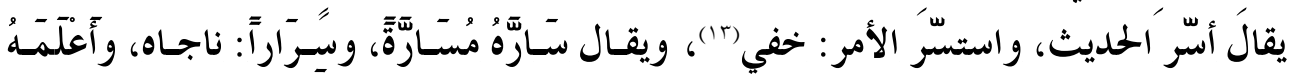

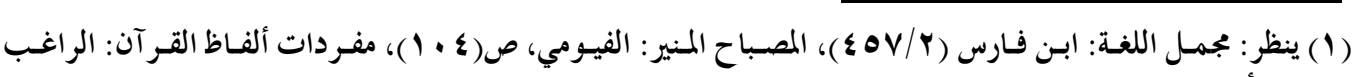

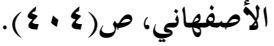

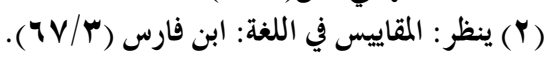

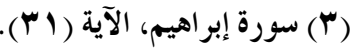

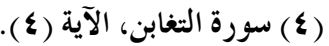

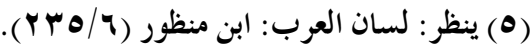

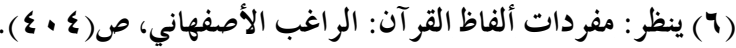

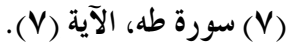

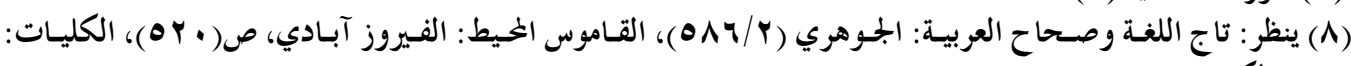

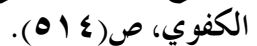

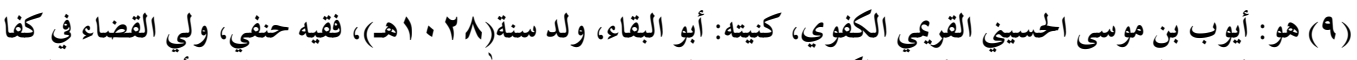

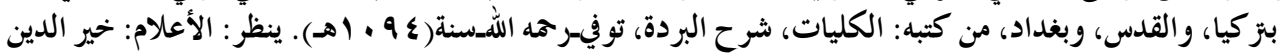

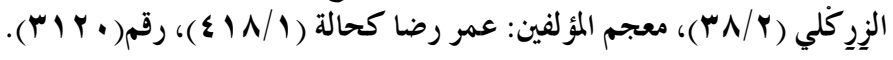

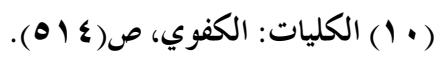

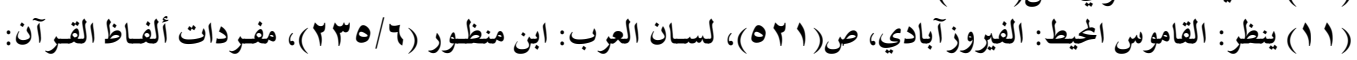

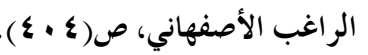

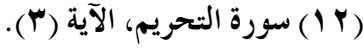

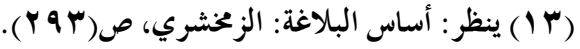

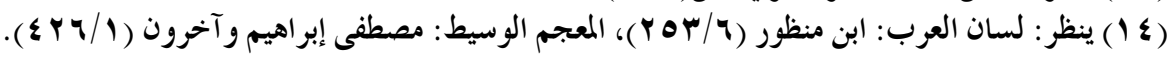


والأسرار من الأضداد (1)، فتأتي أسررت بمعنى كتمت-وهو الغالب-، وتأتي بكعنى أظهرت (r).

ثانياً: تعريف السِّر اصطلاحًاً.

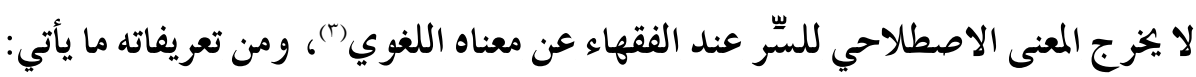

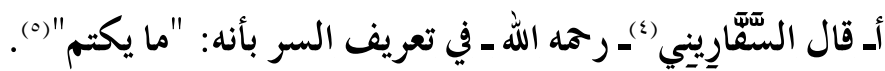

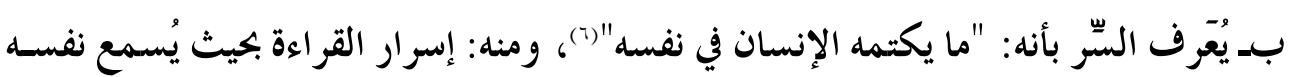
دون إبماع الآخرين (v)

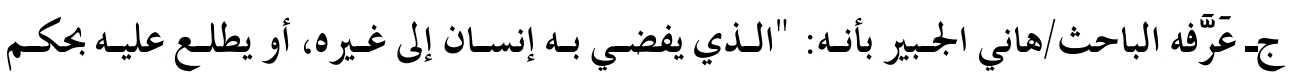

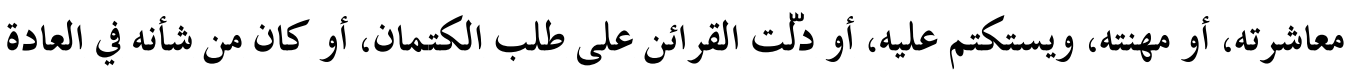

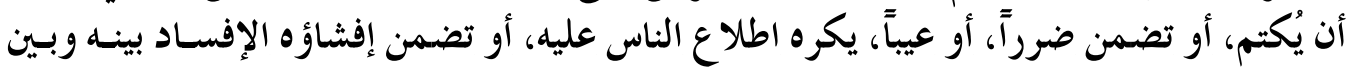

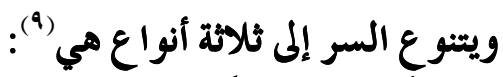

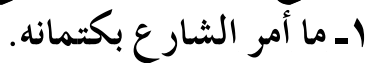

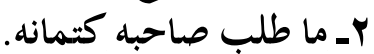

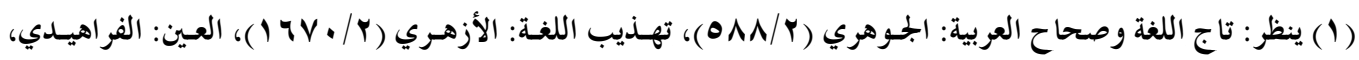

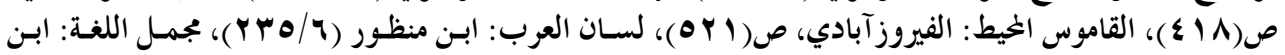

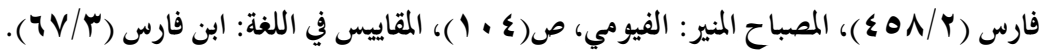

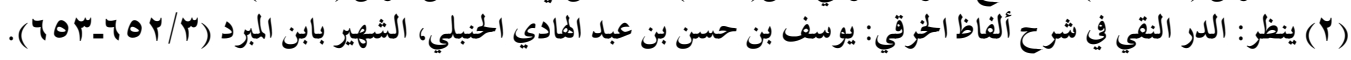

(T) ينظر : إفشاء الأسر ار وأحكامه في الفقه الإسلامي: محمد بن أحد واصل، ص(1) (1)، كشاف اصطلاحات الفنون: محمـد

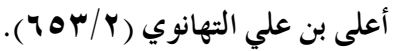

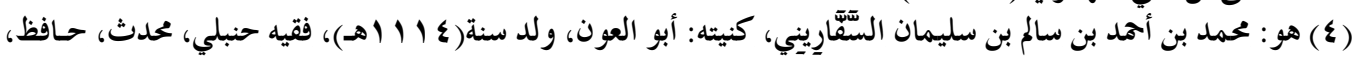

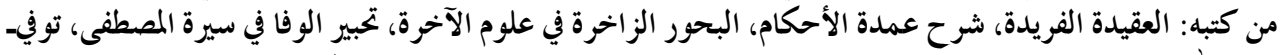

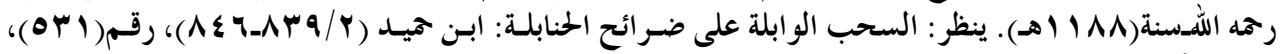

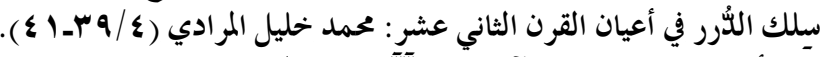

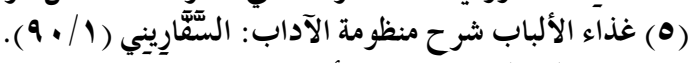

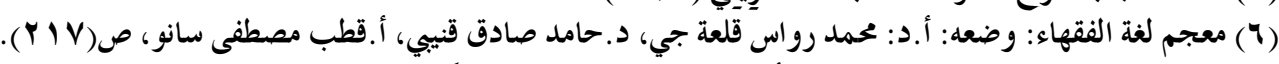

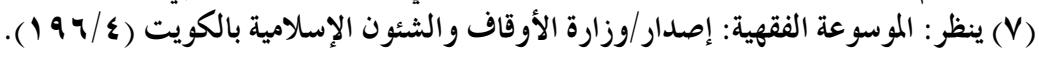

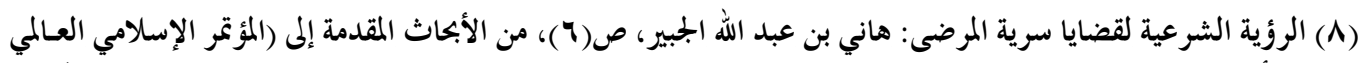

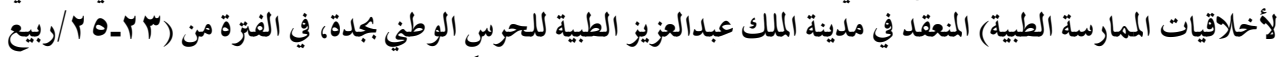

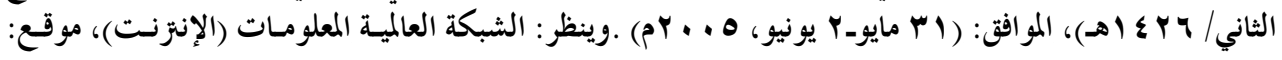

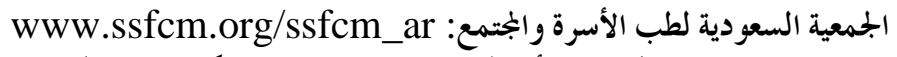

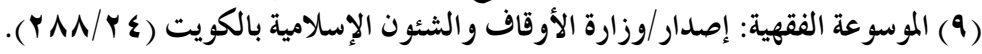




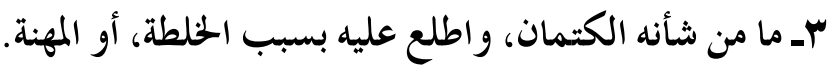

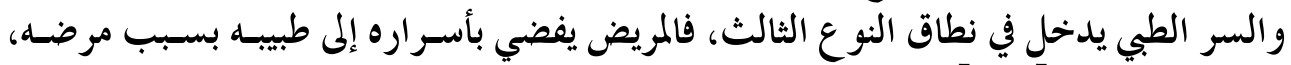

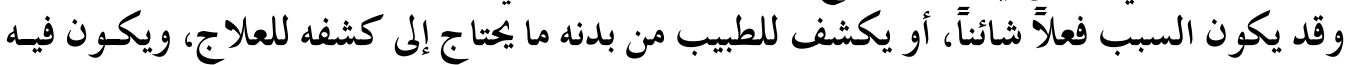

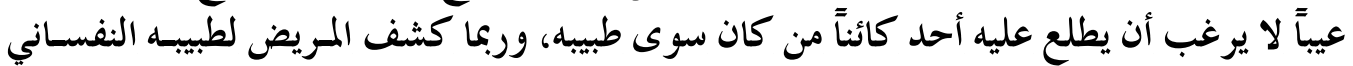

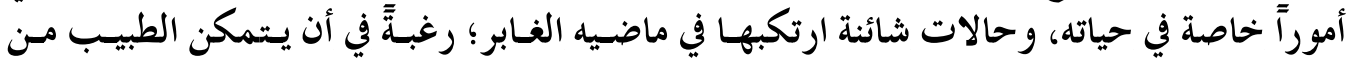

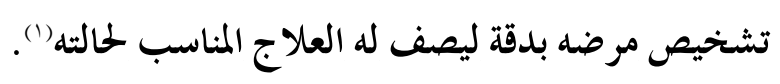

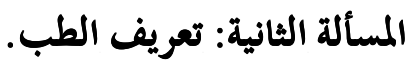

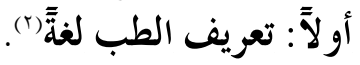

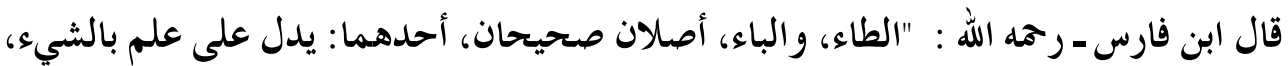

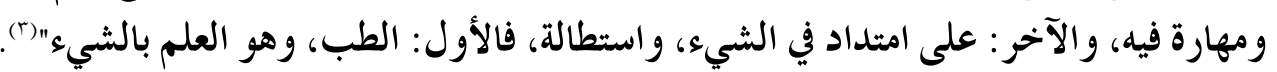

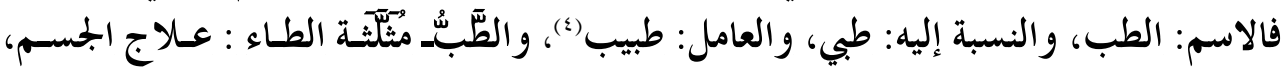

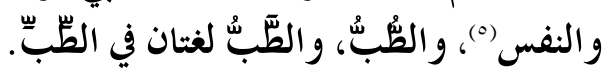

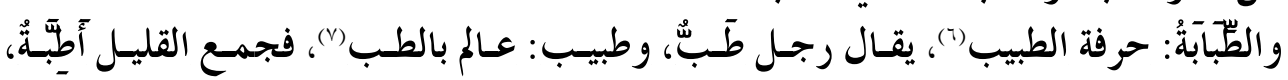

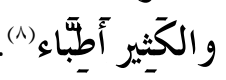

والطبيب في الأصل: الحاذق بالأمور، العارف بها، وسمي بها الطبيب الذي يعا لج المرضى (9).

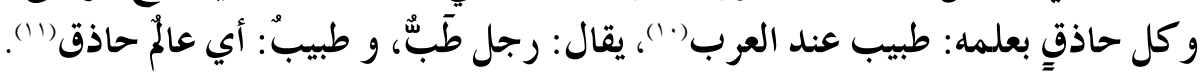

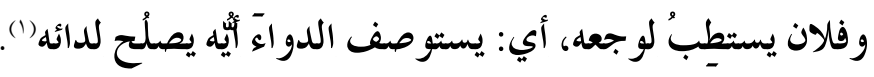

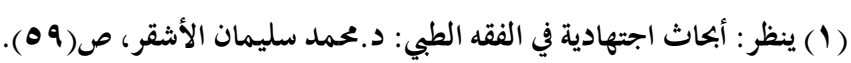

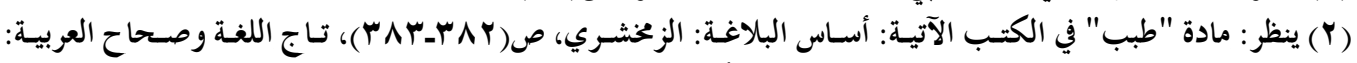

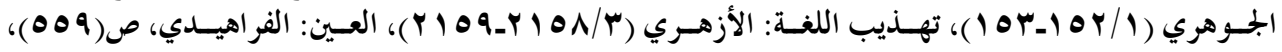

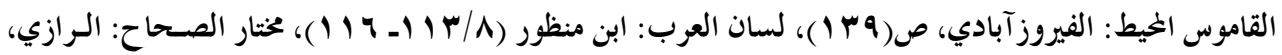

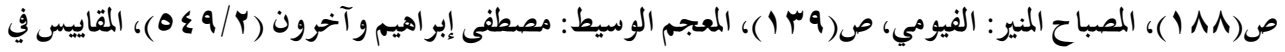

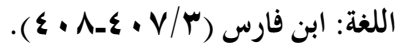

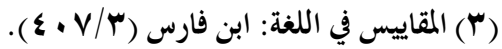

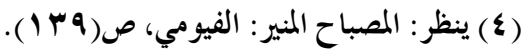

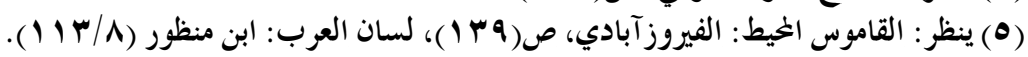

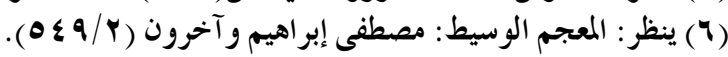

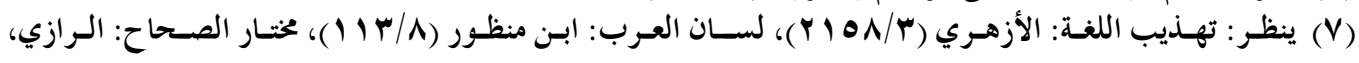

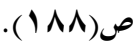

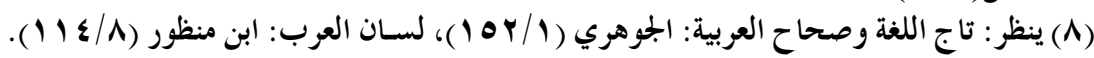

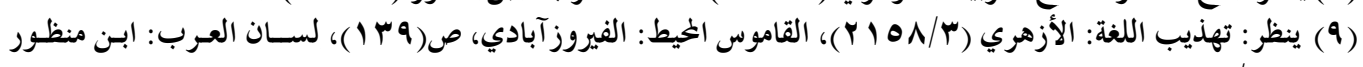

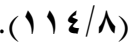

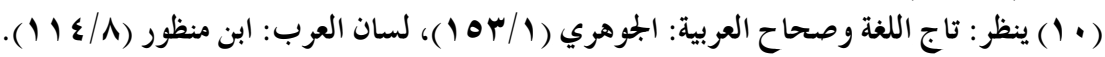

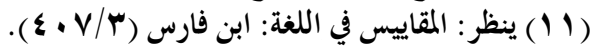




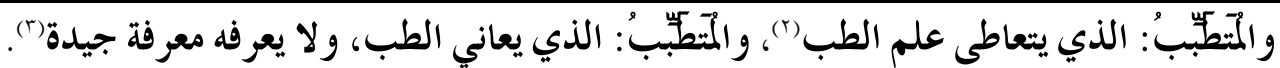
ثانياً: تعريف الطب اصطلاحًاً.

يعرف علم الطب بأنه: "علمٌ بقو انين يعرف بها حالات الصحة،، والمرض، وتأثير الأدوية"(؛). ومن تعريفات الفقهاء للطب ما يأتي:

اـ الطب: "علمُ بقو انين تُعْرَُّ منها أحوال أبدان الإنسان من جهة الصحة، وعدمها"(•).

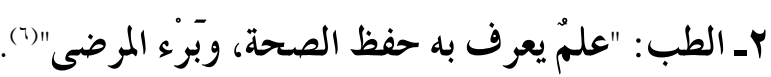

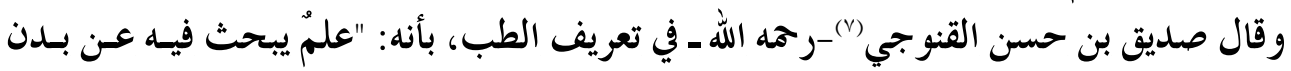

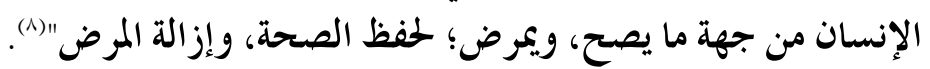
* تعريف الطبيب:

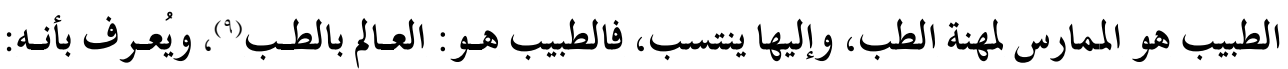

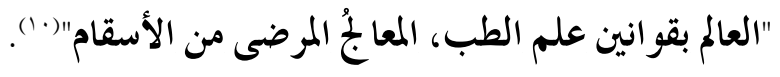

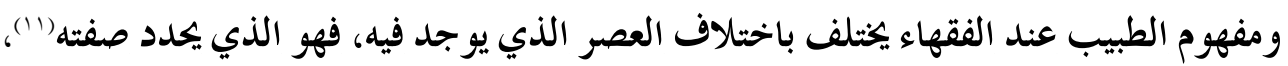

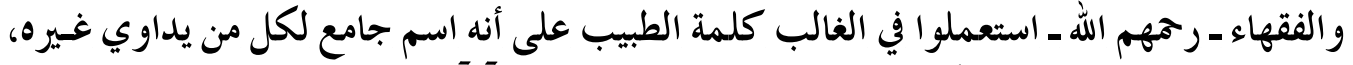

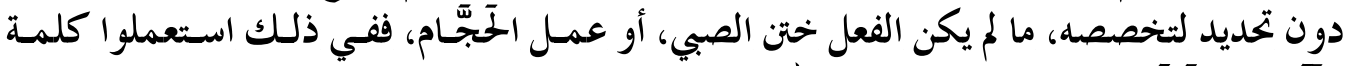

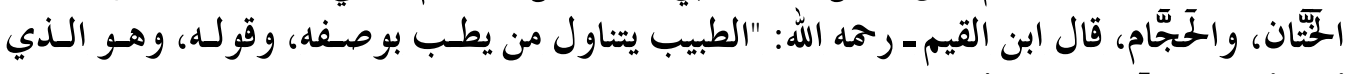

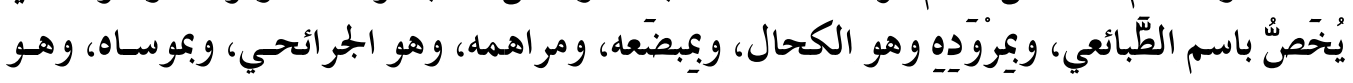

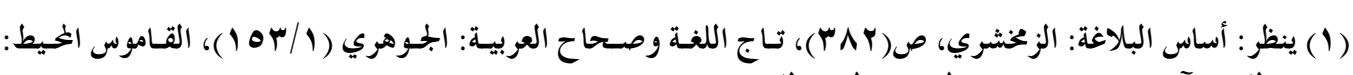

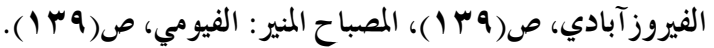

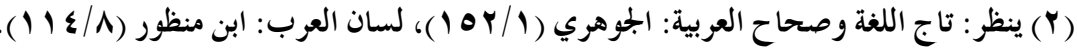

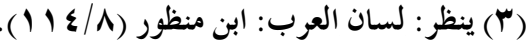

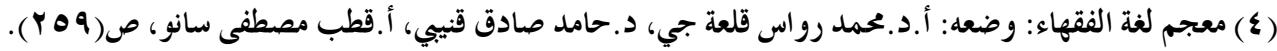

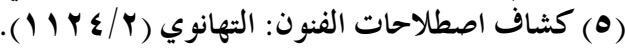

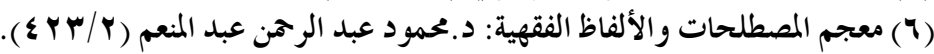

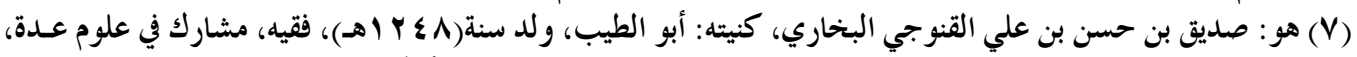

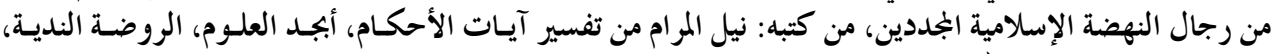

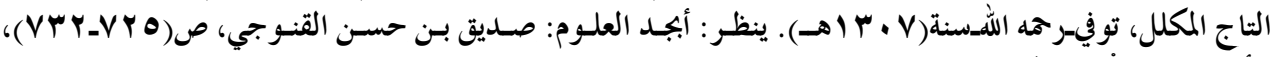

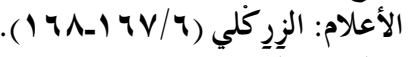

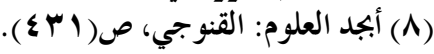

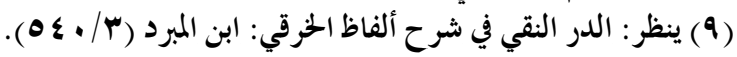

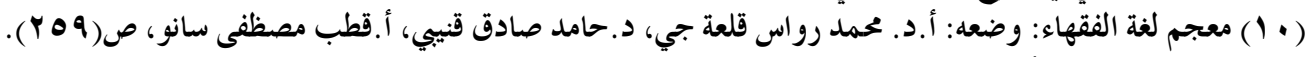

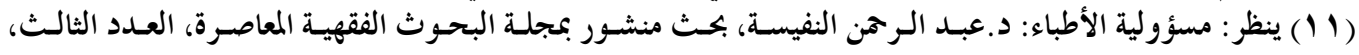




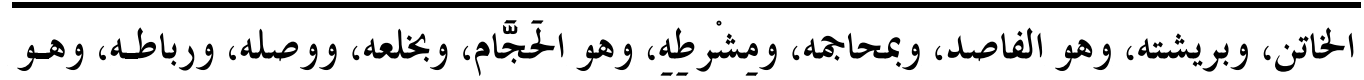

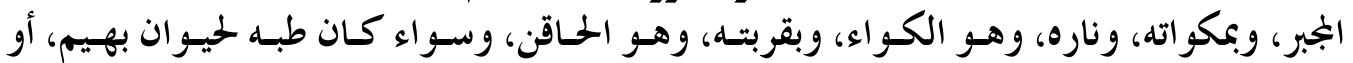

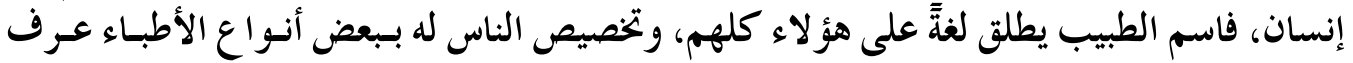
حادث" (1)

كما أطلق قديمًا على من يمارس مهنة الطب لفظ "الحكـيم"، ولا يـزال هـذا اللفـظ مسـتعملاً في

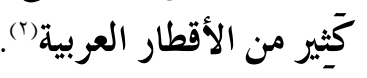

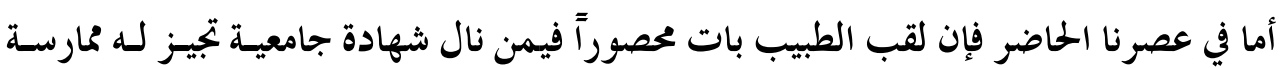

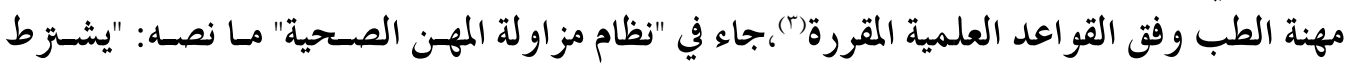
للمزخيص بمزاولة المهن الصحية ما يأتي:

1 - الحصول على المؤهل المطلوب للمهنة من أي كلية طبية، أو كليـة صسيدلة، أو كليـة علدوم

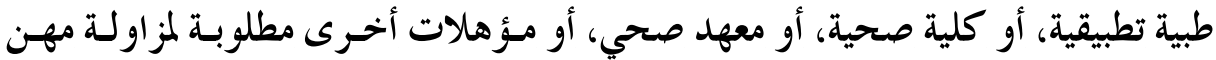

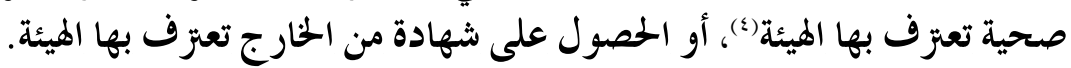

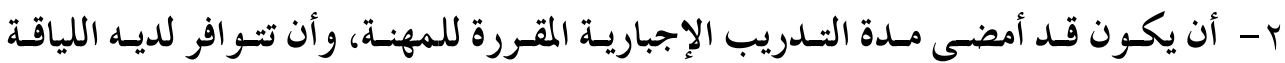
الصحية. r- التسجيل لدى الهيئة، و فققاً لمتطلبات التي تحددها. ع - ألا يكون قد سبق الحكم عليه في جريمة مخلة بالشرف أو الأمانة، إلا إذا رد إليه اعتباره"('). اعتباره" (•)

\section{الفرع الثاني: التعريف الاصطلاحي للسّر الطبي.}

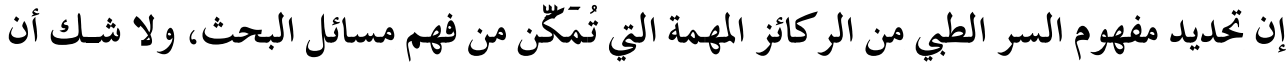

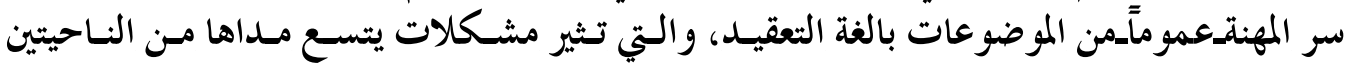


الشرعية، والقانونية، حتى إن (أكاديمية العلوم السياسية والأخلاقية) في فرنسا، رصدت لوان للبحث فيه

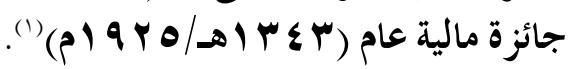

$$
\text { وفيما يأتي أهم تعريفات السّر الطبي: }
$$

*التعريف الأول: عرف الـدكتور/أسـامة عبـد الله قايـد، السِّر الطبي بقوله: "هـو كـل أمـر،

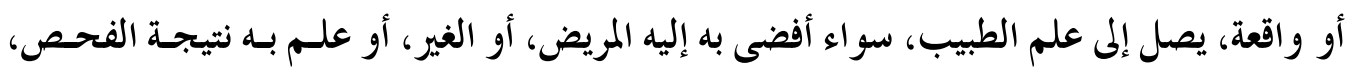

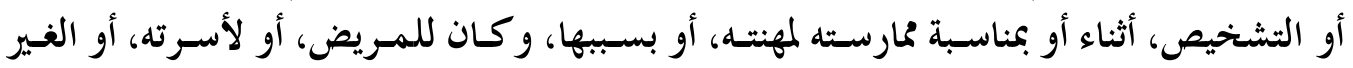

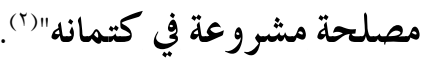

\section{ونلحظ على التعريف ما يأتي:}

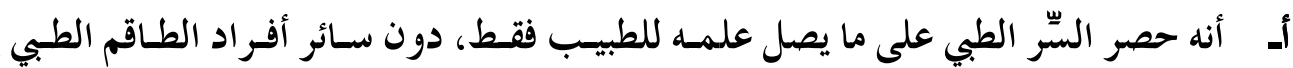

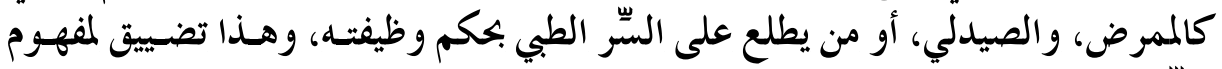

$$
\text { السِّر الطبي. }
$$

بـ قوله: "و كان للمريض، أو لأسرته، أو الغير مصلحة مشروعة في كتمانسه": وعلى هـذا فــلا

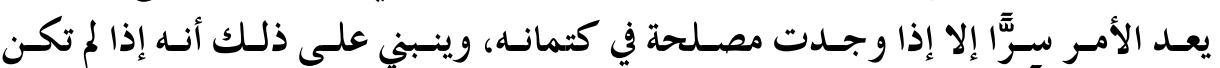

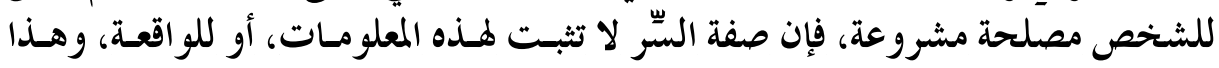

$$
\text { موطن خلاف. }
$$

*التعريف الثاني: عََّّف الدكتور/علي داود الجفال، السِّر الطبي بأنه: "كل مـا يعرفهـ الطبيـب أثناء ممارسته مهنته، و كان في إفشائه ضرر لشخص، أولى أو لعائلة" ("). ونلحظ على التعريف ما يأتي:

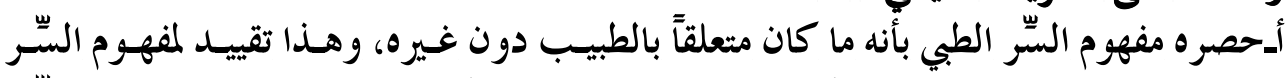

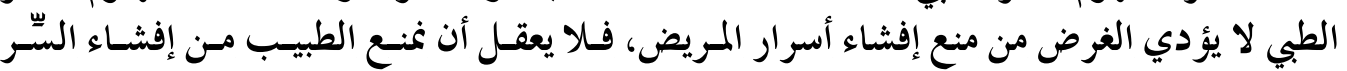

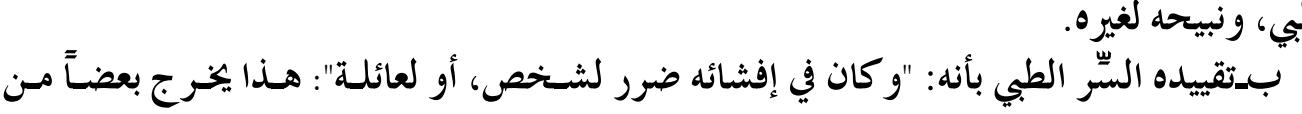

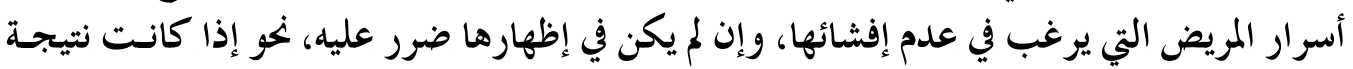

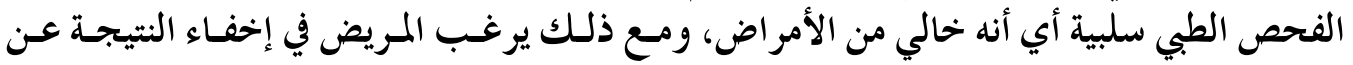

(1) ينظر : المسؤولية الجز ائية للأطباء عن إفشاء السّر المهني: موفق علي عبيد، ص(7) اله ).

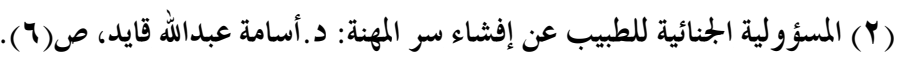

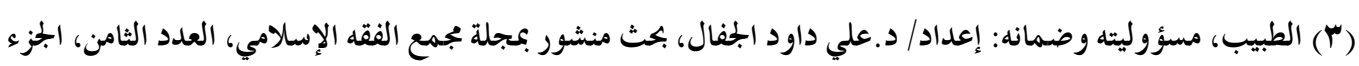


"التعريف الثالث: عرف الدكتور / بابكر الشيخ، السِّر الطبي بأنه: "كل ما يعرفه الطبيـب أثنـاء

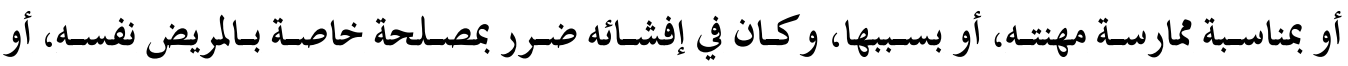

\section{ونوقش التعريف كسابقه.}

* التعريف الرابع: عرف الدكتور ضياء نوري حسن، السِّر الطبي بأنسه: "كـل مـا يطلـع عليسه الطبيب من أحوال مريضه الصحية، وما قد يراه، أو يسمعل، أو يفهمه من مريضه أثناء اتصاله المهني

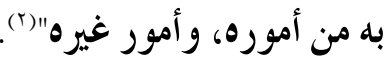

ويلحظ عليه: حصره مفهوم السِّ الطبي في الطبيب فقط من بين أفراد الطاقم الطبي.

* التعريف الحامس: عُرِّفَّ السِّر الطبي بأنه: "كتمان ما اطلع عليه الطبيب من أحسوال مريضسه، وتشمل هذه المعلومات الخاصة التي يحصـل عليهـا الطبيـب بصـورة مباشـرة أو غـير مباشـرة خــلال

ونلحظ على هذا التعريف ما يأتي:

أ-قوله: "كتمان": فهذا لا يدخل في تعريف السِّر الطبي بل هو من آثاره، ونتائجه.

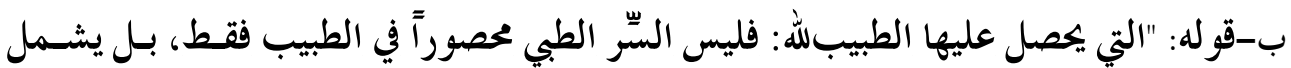

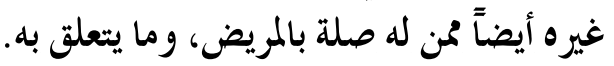

*التعريف السادس: عُرِّفَّ السِّر الطبي بأنه: "ما وصل إلى علم المنوط بحفظ السِّ بطريق مباشر،

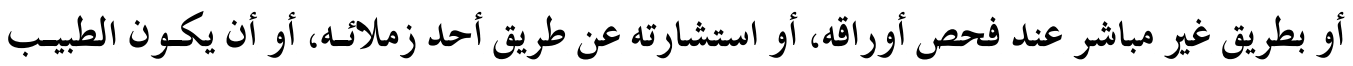

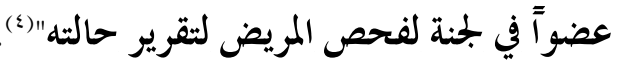

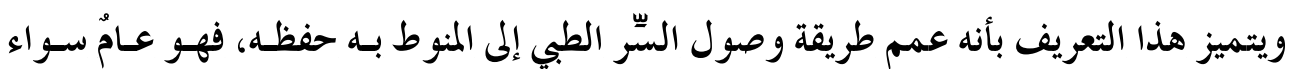

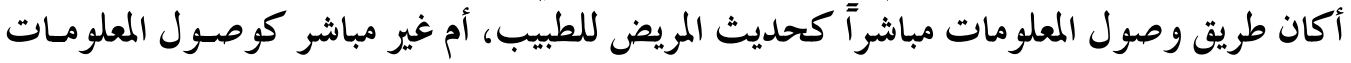
عن طريق زملاء المهنة. ونلحظ على التعريف:

(1) المسؤولية القانونية للطبيب: د.بابكر الشيخ، ص(ه ؟ץ).

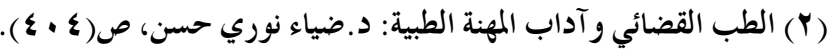

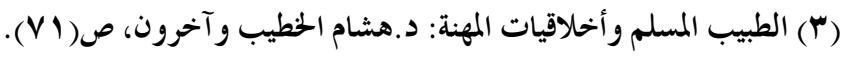
( (8) سر المهنة بين الكتمان والعلانية: إعداد/ د. أحمد رجائي الجندي، بحث منشور بحجلة مجمع الفقه الإسلامي، العدد الثامن، 
حصر السِّر الطبي في الطبيب فقط دون غيره، والأولى تعميم ذلك على كل من له صسلة بالسِّر

\section{وقفات مع تعريفات السّر الطبي:}

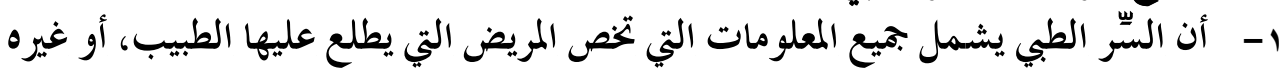

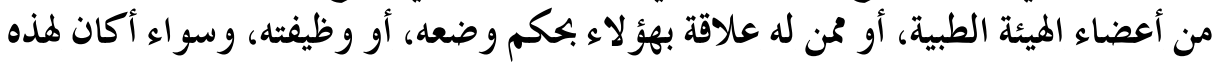

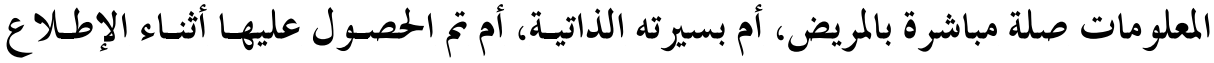

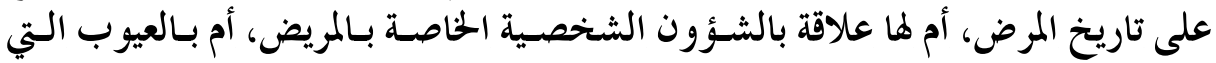

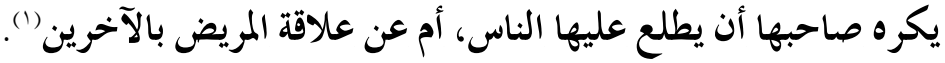

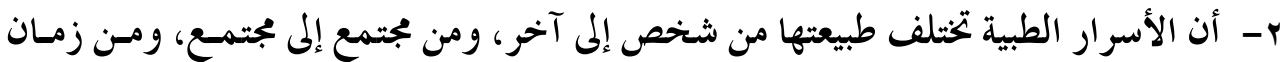

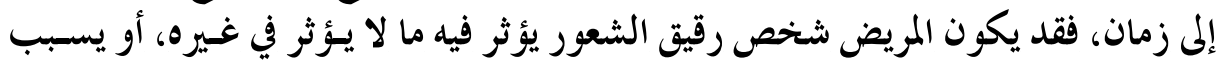

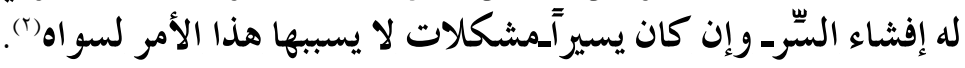

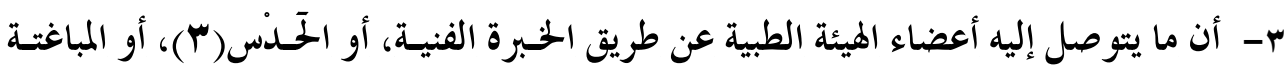

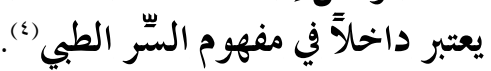

ع - أن المعلومات التي يجصل عليها أحد أعضاء الهيئة الطبية من الفير، ولها صلة بالمريض، تكون

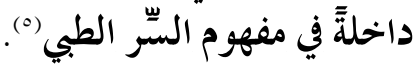

ه- للسر الطبي خصائص عدة منها")

أ. إيمـان الجماعـة العفـوي بـه، واعتمــادهم إيّــاه تقليـداً يتوارثونـه عـبر الأجيـال، تتميـز فيسه خصو صية علاقة الطبيب بالمريض. ب. قوة السِّر الطبي، وفعاليته، و أثره الجلي.

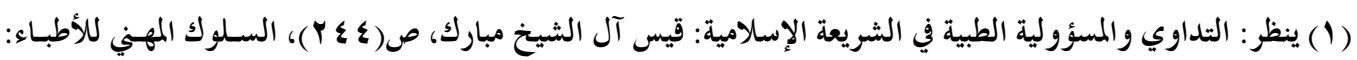

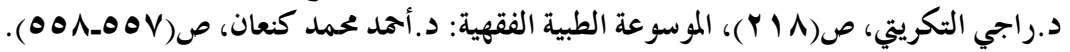

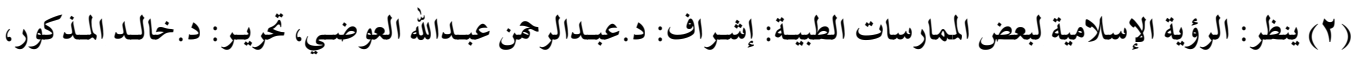

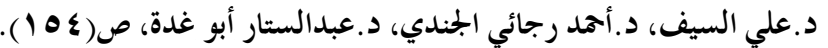

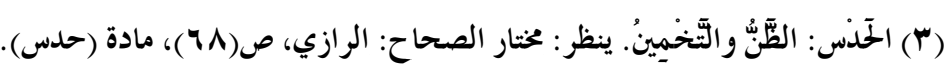

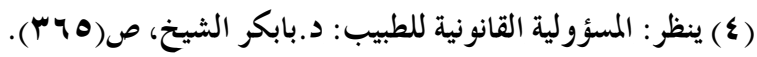

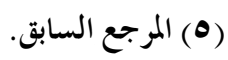

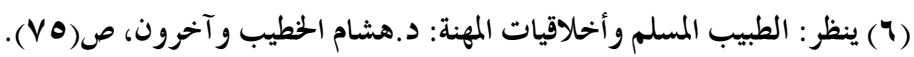
- 100 _ 


$$
\begin{aligned}
& \text { الفصل الأول } \\
& \text { تاريخ السّر الطبي، ونطاقه، وأساس الالتزام به الأه } \\
& \text { المبحث الأول: تاريخ السّر الطبي. }
\end{aligned}
$$

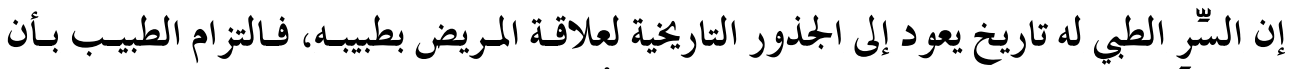

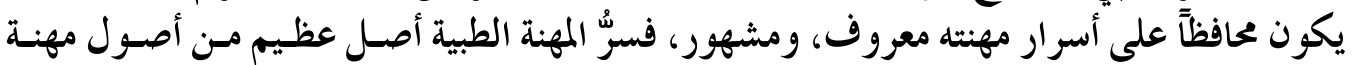

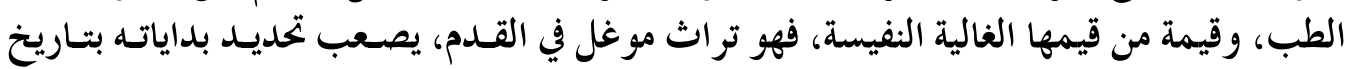

\section{ويتضح تاريخ السّر الطبي في النقاط الآتية:}

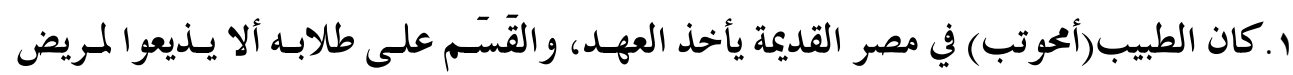

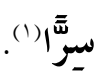

r.كان السّر الطبي من الالتزامات الطبية التي يقطعها الطبيب على نفسه منذ أقدم الأزمنة، ومن

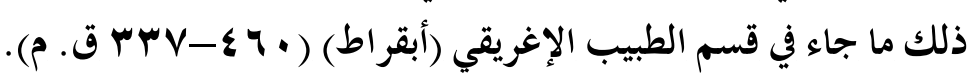

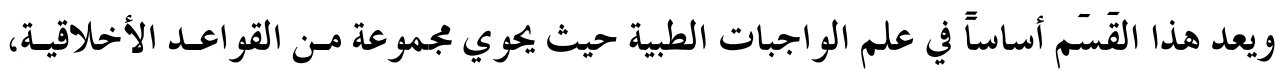

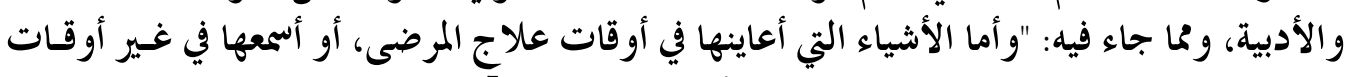

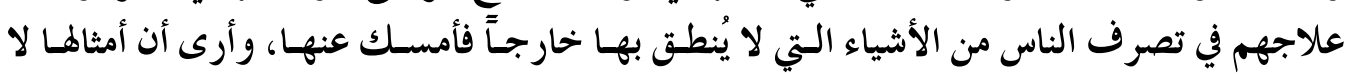

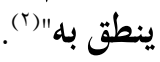

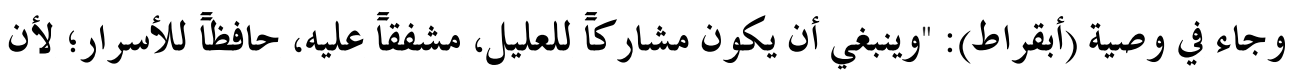

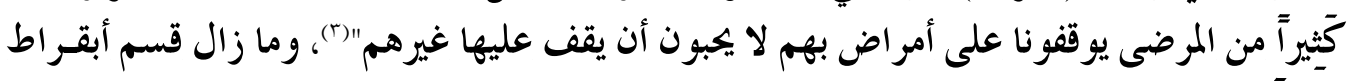

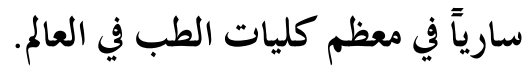

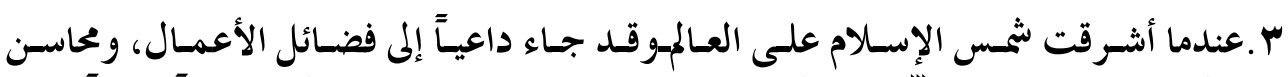

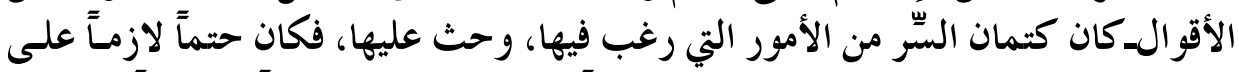

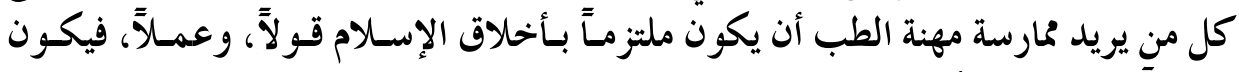

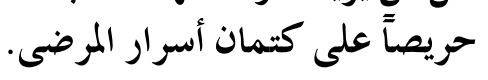

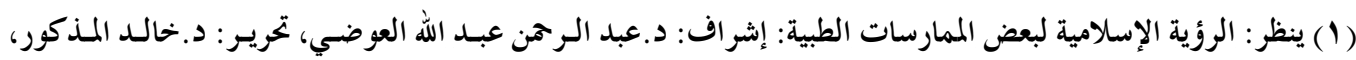

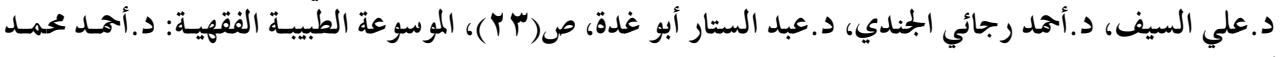

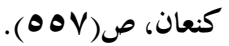

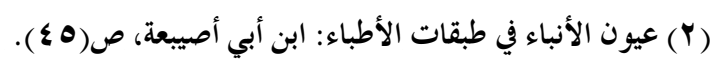




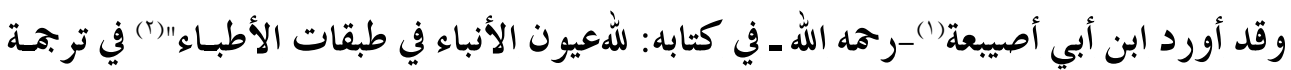

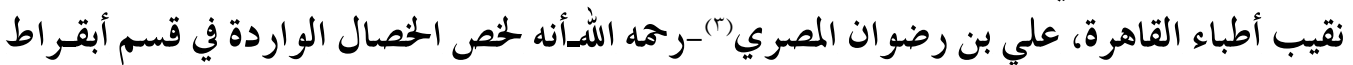

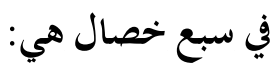

أ) أن يكون تام الخلق، صحيح الأعضاء، حسن الذكاء، جيد الرؤية، عاقلاً، فاضل الطبع. ب) أن يكون حسن الملبس، طيب الرائحة، نظيف البدن، و الثوب. ج) أن يكون كتوماً لأسرار المرضى، لا يبوح بشيء من أمراضهم. د) أن تكون رغبته في إبراء المرضى أكثر من رغبته فيما يلتمسه من الأجرة، ورغبته في عـلاج الفقراء أكثر من رغبته في في علاج الأغنياء.

هـ أن يكون حريصًاً على التعليم، والمبالغة في منافع الناس.

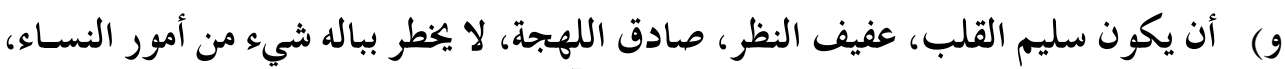

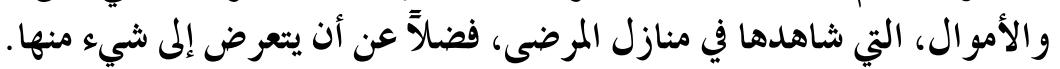

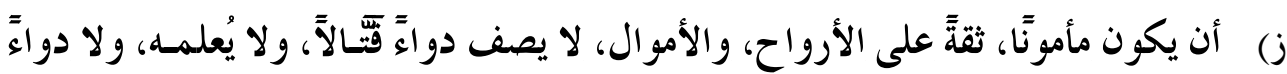

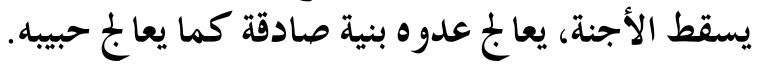

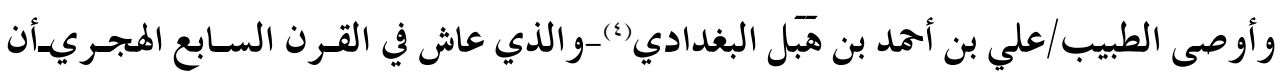

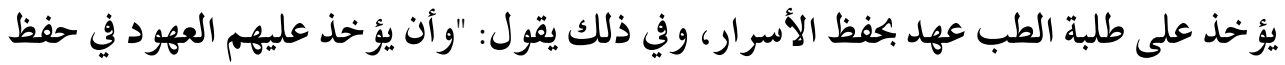

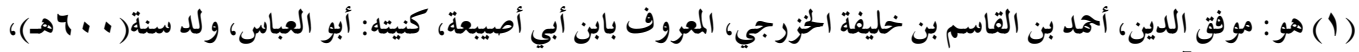

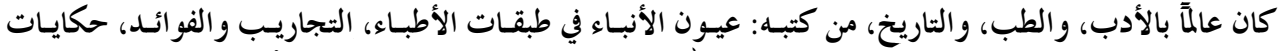

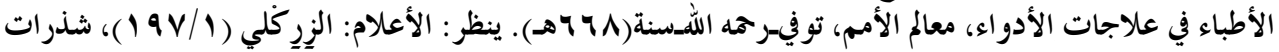

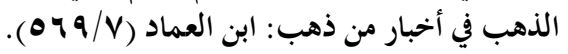

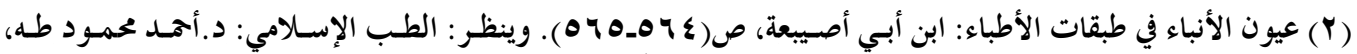

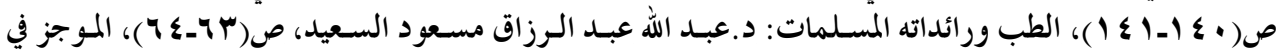

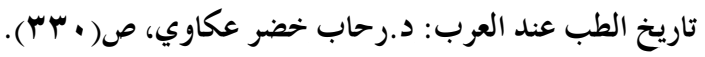

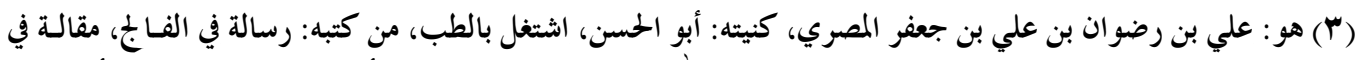

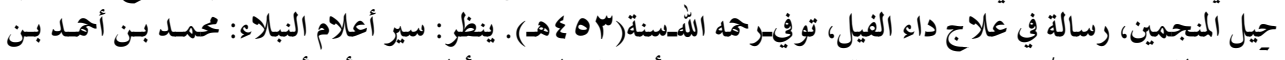

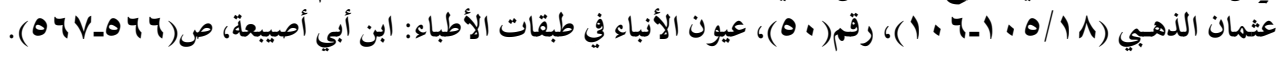

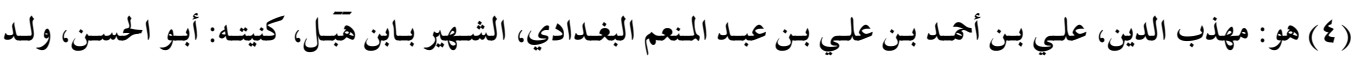

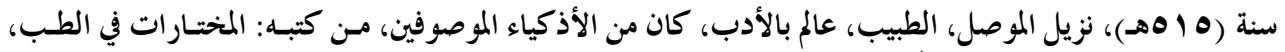

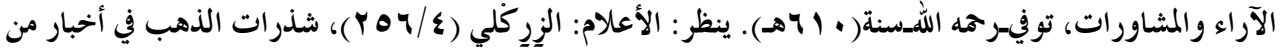


الأسرار، فإنهم يطلعون على ما لا يطلع عليه الآباء والأولاد، من أحوال الناس"(1).

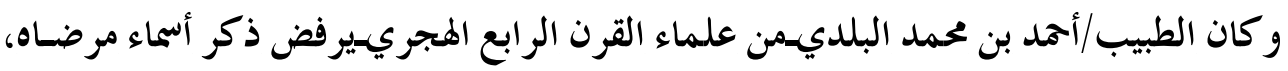

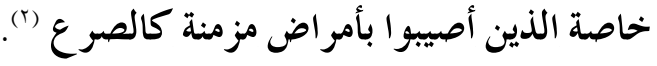

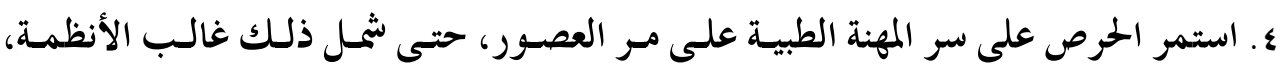
و القو انين الطبية، ومن ذلك: الكتئ

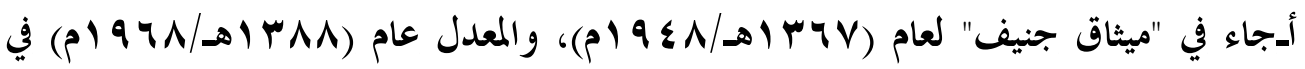

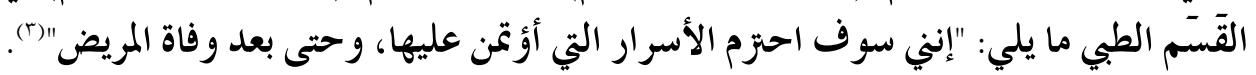

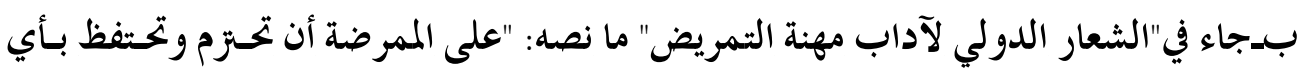

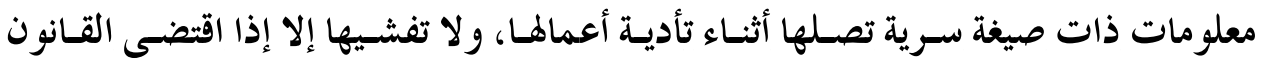

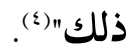

ج-جاء في"الميثاق الأخلاقي للمشتغلين بعلم النفس في مصر" ما نصه: "الاخصائي النفسي مـؤتنن

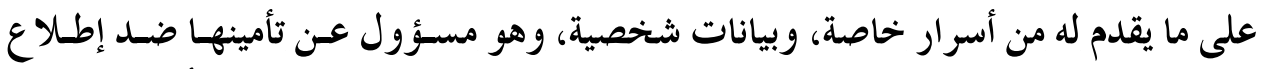

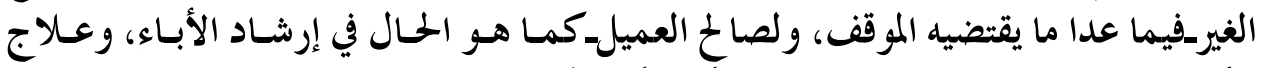

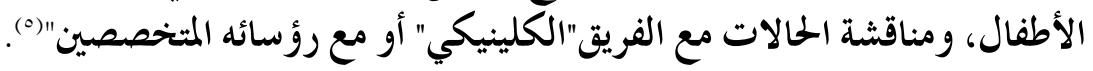
هـ أول من أدخل موضوع سر المهنة في برامج التدريس بكليات الطب بمصر هو الدكتور /محمد

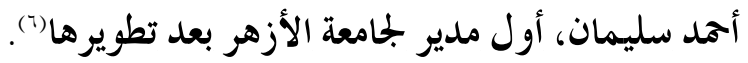

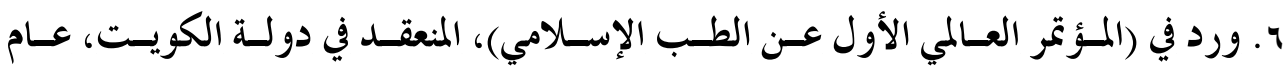

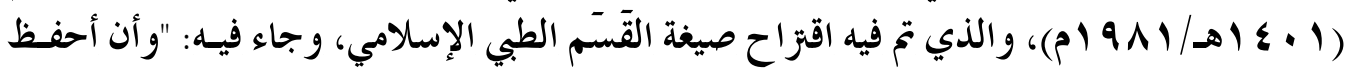

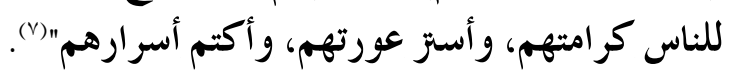

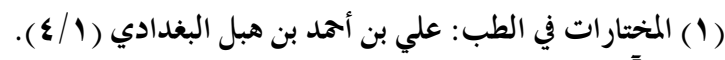

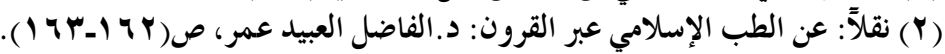

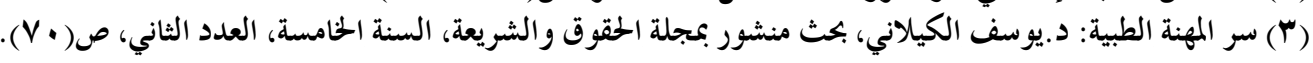

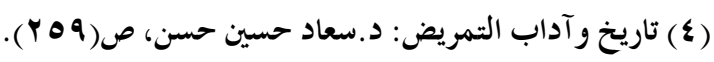
(ه) دراسات نفسية: دورية علمية ربع سنوية محكمة، تصدر عن رابطة الأخصائيين النفسيين المصرية "رانئ، العـدد الثـاني،

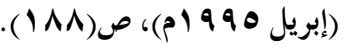

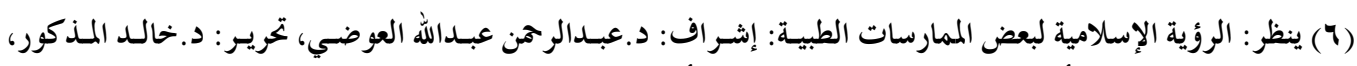

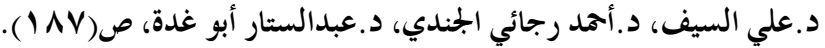

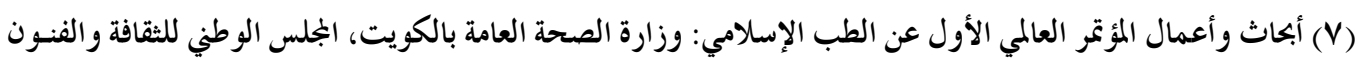




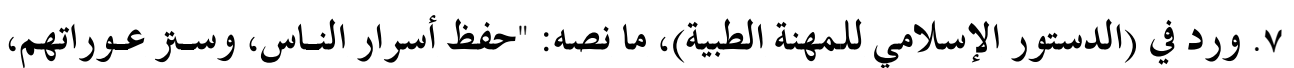

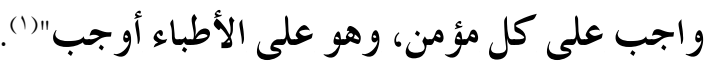

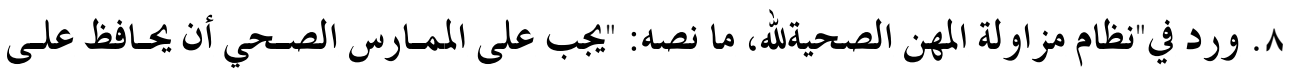

الأسرار التي علم بها عن طريق مز اولة مهنته" (').

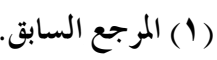

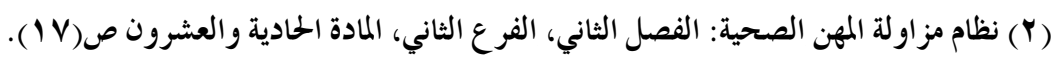
- . - 


$$
\text { نطـاق السّر الطبّ الثاني }
$$

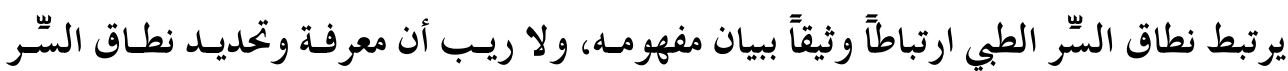

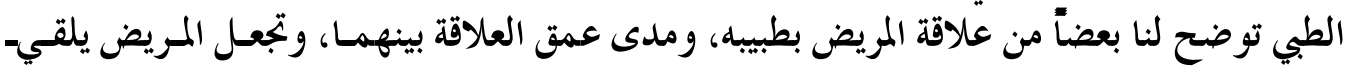

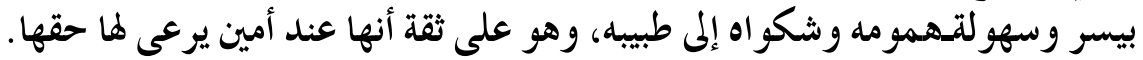

\section{واختلف العلماء في تحديد نطاق السّر الطبي على ثلاثة أقوال هي:}

القول الأول: الرجوع في تحديد نطاق السِّر الطبي إلى العـرف، وإلى ظروف كـل حادثـــ على

والمقصود أن يُرجع في طبيعة السّر إلى عرف الناس، فما عدوه سِرَّا كان كذلك، وما لا فلا.

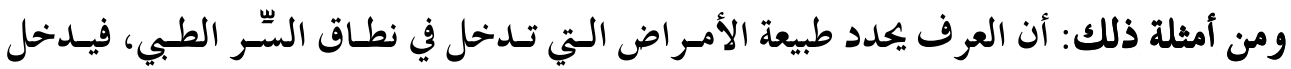

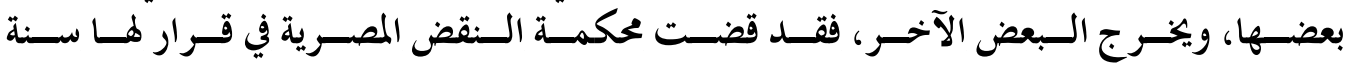

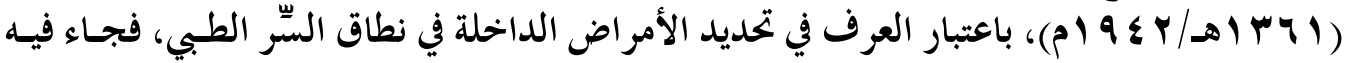

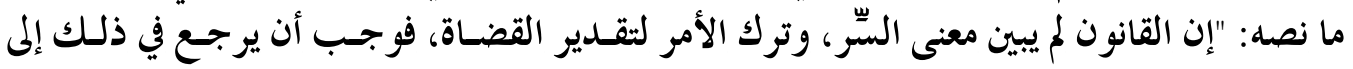

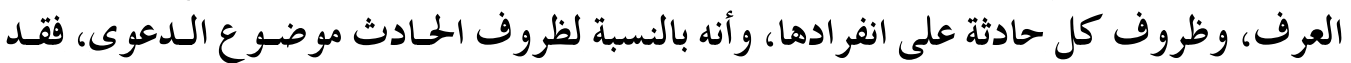

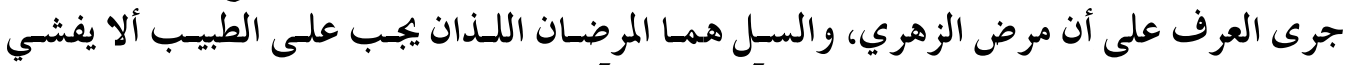

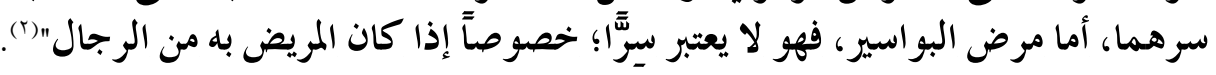

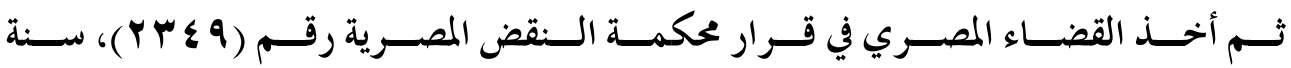

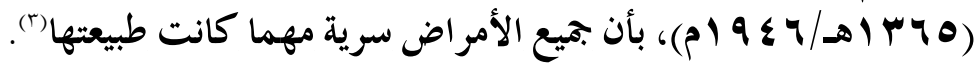

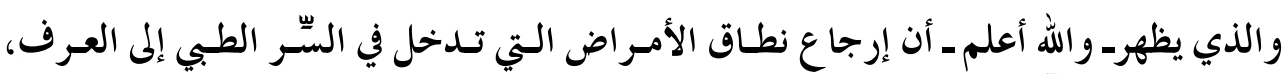

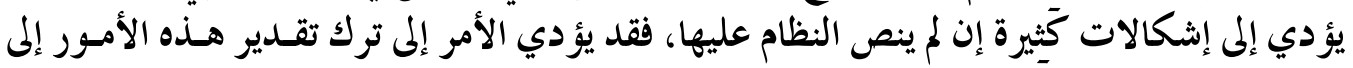

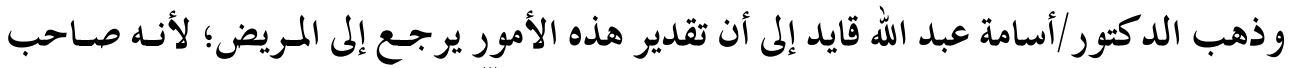

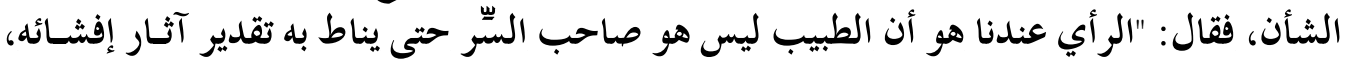

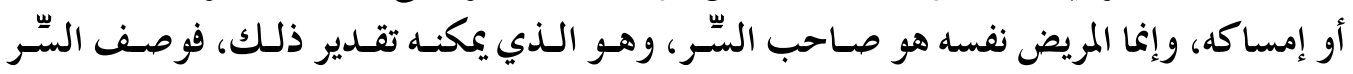

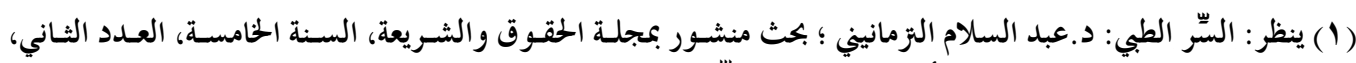

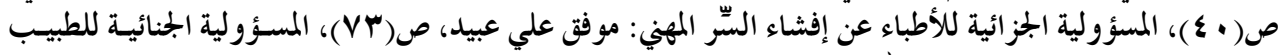

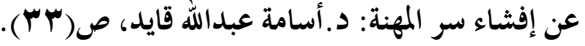

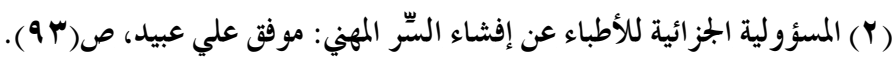

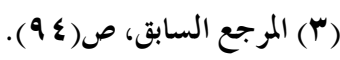




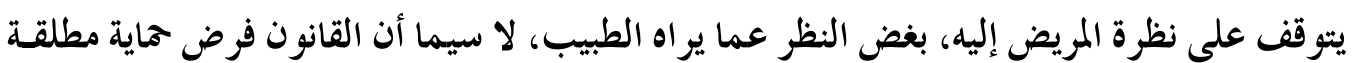

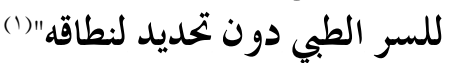

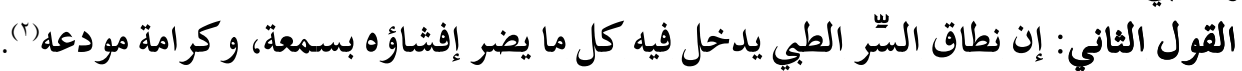

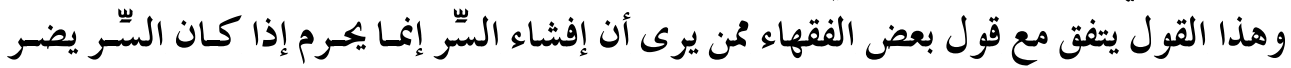

بصاحبه. القول الثالث: إن نطاق السِّر الطبي يـدخل فيسه كـل أحسداث الحيـاة الـتي يحـرص النـاس على

وهذا القول يجعل العرف مرجعاً مهماً في معرفة ما يحرص الناس على كتمانه. وحددت بعض الأنظمة نطاق السِّ الطبي، ونصت عليه، ومن ذلك:

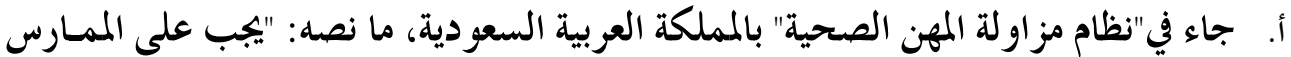

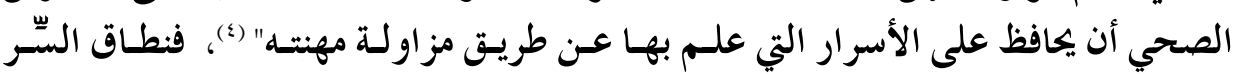

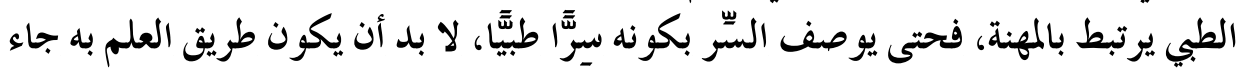
عن طريق ممارسة الطبيب مهام عمله.

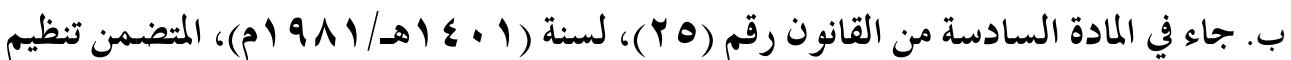

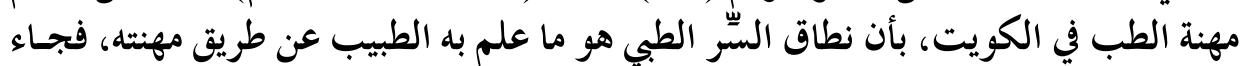

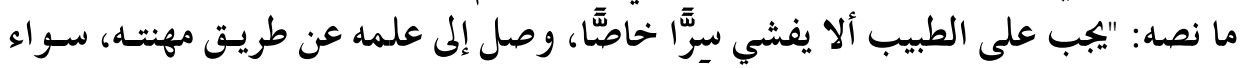

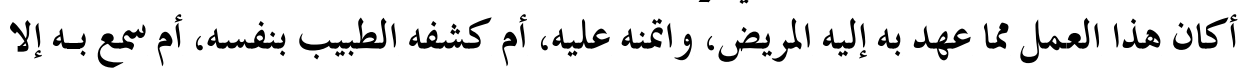
بأمر الخكمة؛؛ لتحقيق سير العدالة"(•).

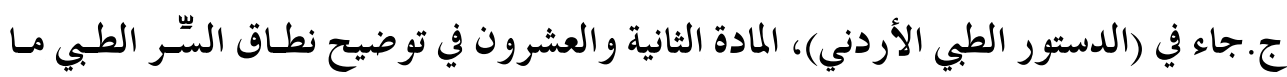

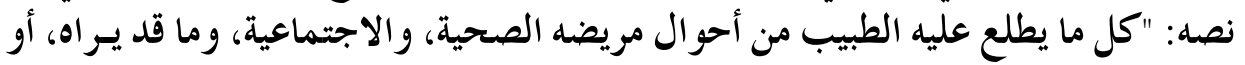

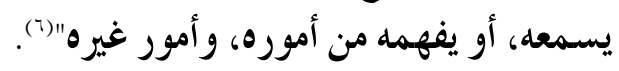

(1) المسؤولية الجنائية للطبيب عن إفشاء سر المهنة: د.أسامة عبدالله قايد، ص(ع ؟).

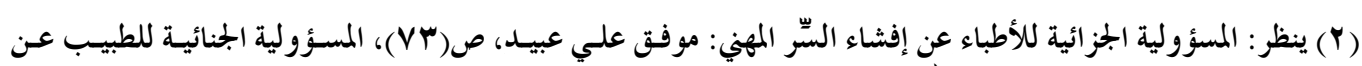

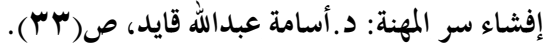

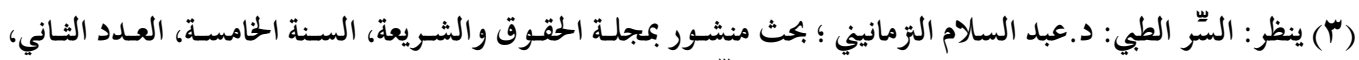

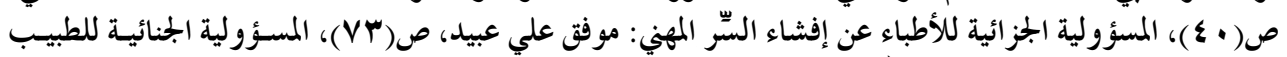

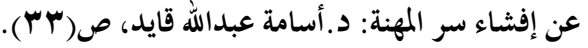

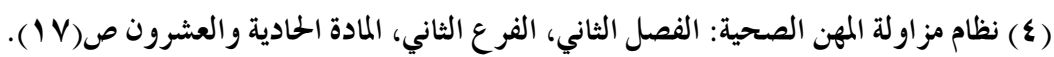
(•) السّّر الطبي: د.عبدالسلام التزمانيني، بحث منشور بمجلة الحقوق والشريعة، السـنة الخامسـة، العـدد الثـاني، ص(ع ع )،

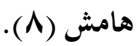

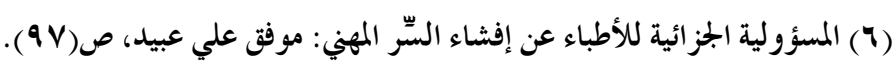


د. جاء في تعليمات (السلوك المهني للأطباء) في العراق، ما نصه: للديدخل في نطساق السِّرَ الطبي

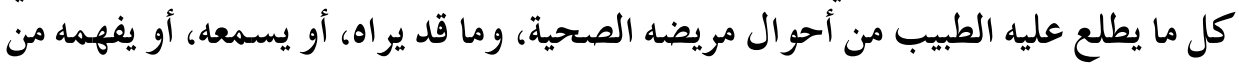

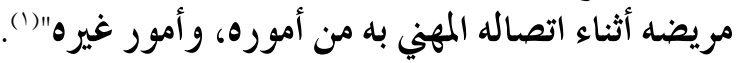

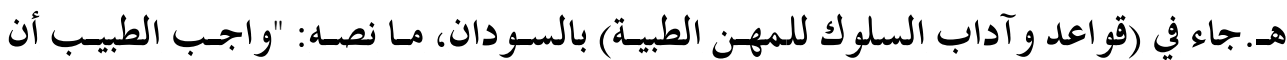

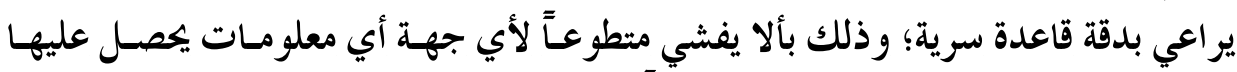

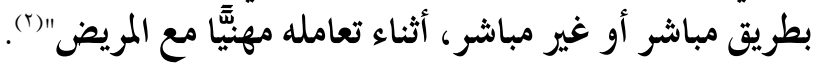

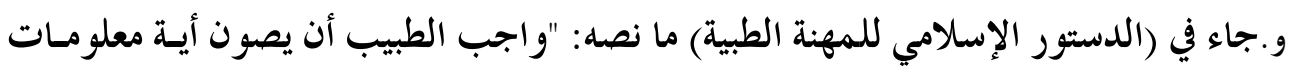

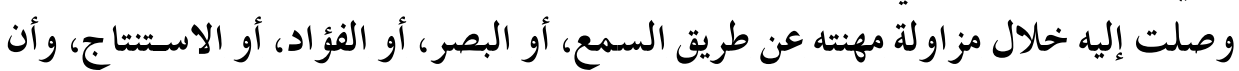
"يجيطها بسيا ج كامل من الكتمان" (").

\section{وجملة الأقوال في تحديد نطاق السِّر الطبي-فيما أعلمينحصر في نظريتين هما:}

* النظرية الأولى: أن نطاق السِّر الطبي يتمثل في إيداع المريض سره للطبيـب، وائتمانـه عليـه على أنه سر (๕)

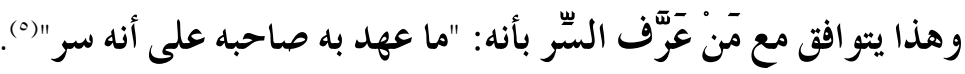

\section{ومما يلحظ على هذه النظرية ما يأتي:}

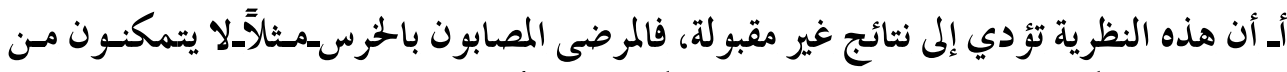

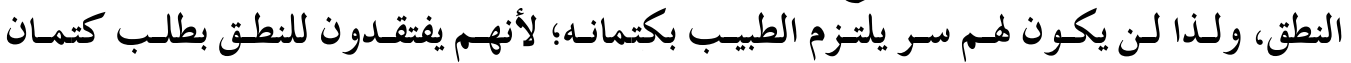
أسرارهم. - (أنطو،

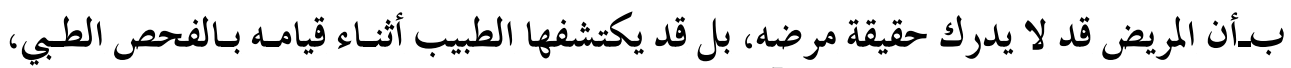

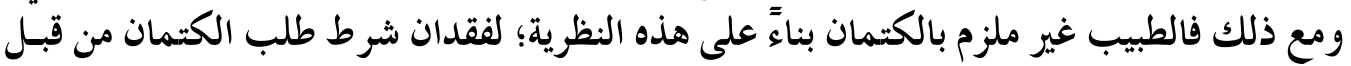


*النظرية الثانية: أن تحديد نطاق السِّ الطبي يعود إلى طبيعـة الأسـر ار، فـلا يشـز ط أن يطلـب

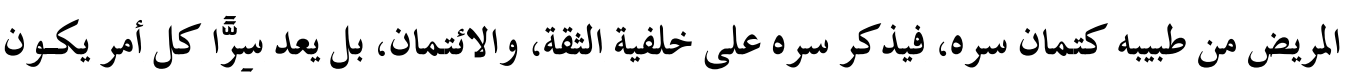

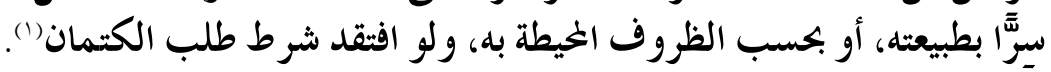

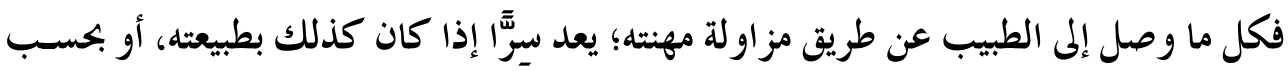
الظروف الخيطة به، فيجب كتمانه.

الز جيح:

الذي يتزجح- والله أعلم ـ النظرية الثانية: أن تحديد نطاق السِّر الطبي يعـود إلى طبيعـة الأسـرار؛

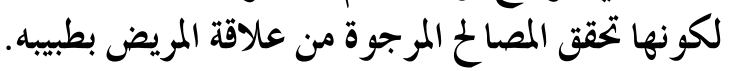
وذهب الأستاذ/موفق علي عبيد في رسالته العلمية: "المسؤولية الجز ائية للأطباء عن إفشاء السِّرِ

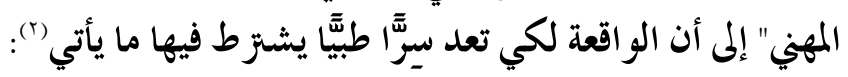
ا ــ أن يعلم بها الطبيب بصفته طبيباً.

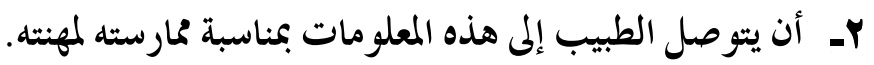

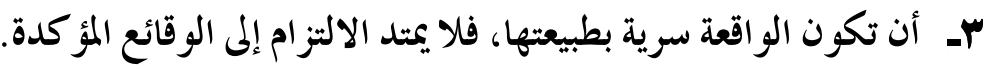

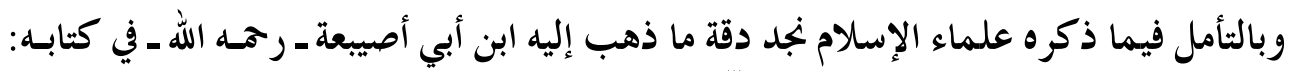

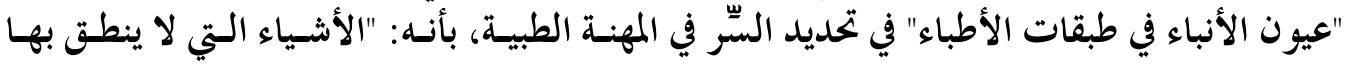

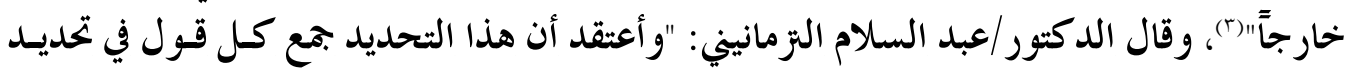

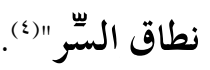

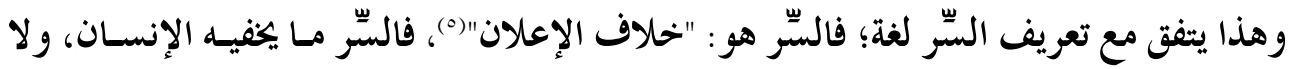

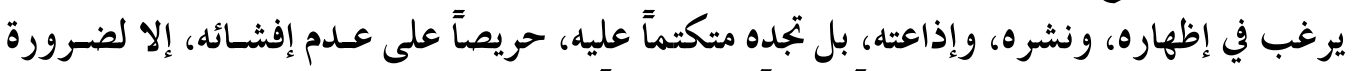

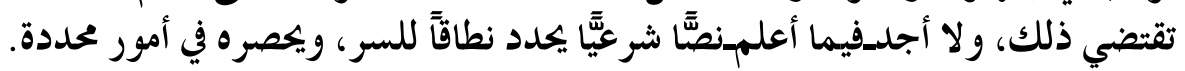

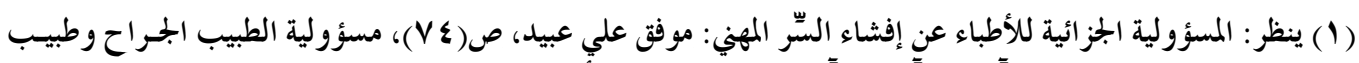

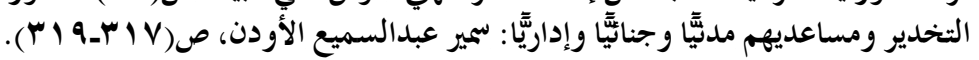

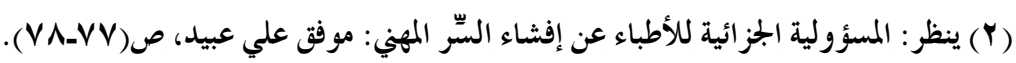

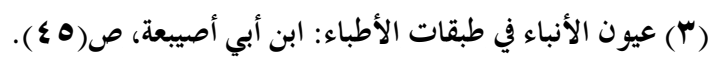

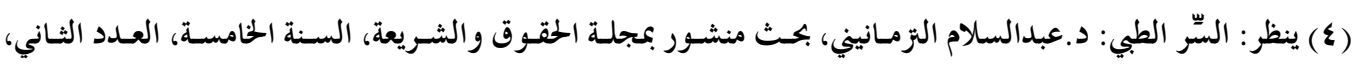

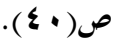

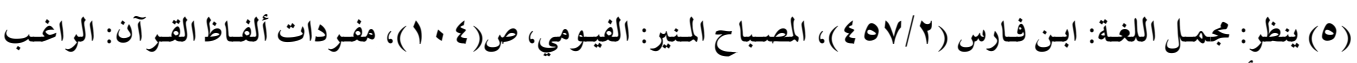




\section{المبحث الثالث}

$$
\text { أساس الالتز ام بالسّر الطبي }
$$

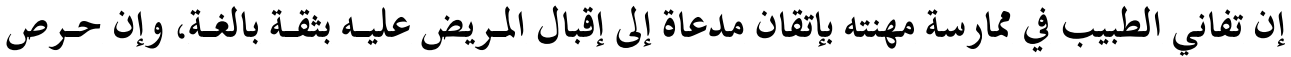

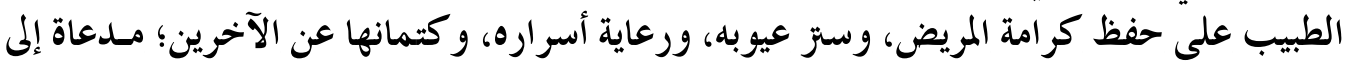

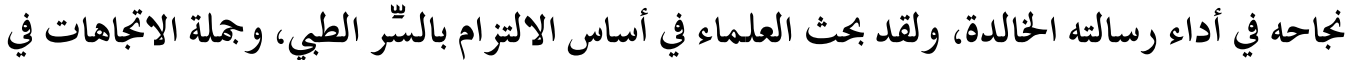
بيان وتفسير أساس الالتز ام بالسِّر الطبي هي:

*الاتجاه الأول: أن أساس الالتزام بالسِّر الطبي هـو: عقــ العـلاج() الـذي يـبرم بـين المـريض،

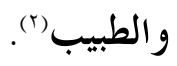

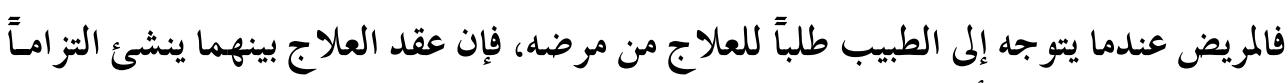

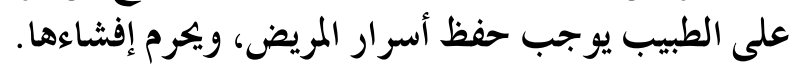

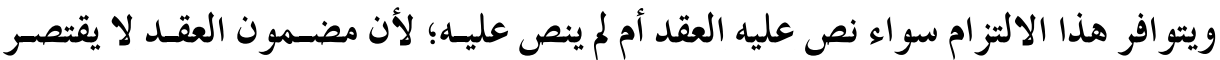

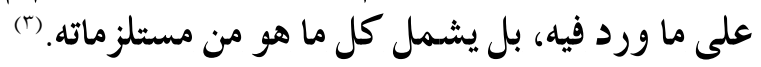

\section{ومما يؤيد هذا الاتجاه(s) - (s)}

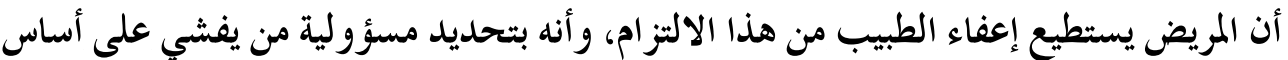

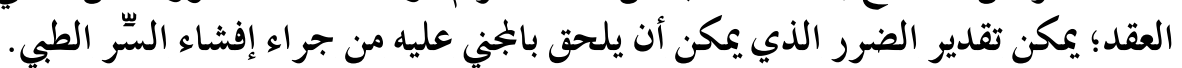

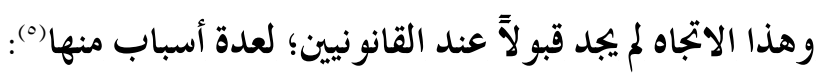

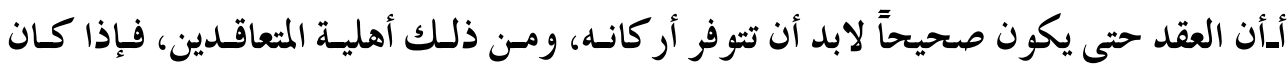

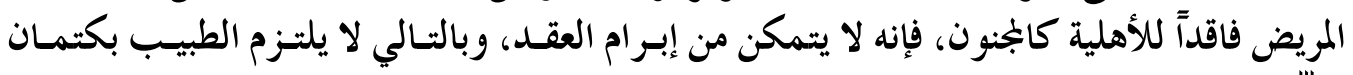

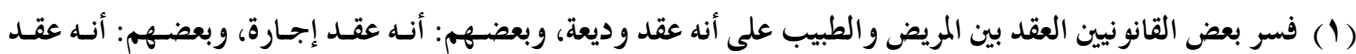

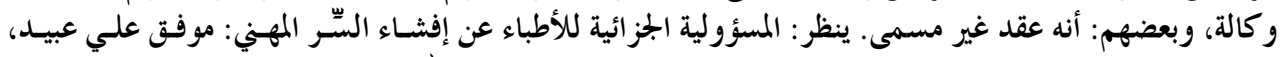

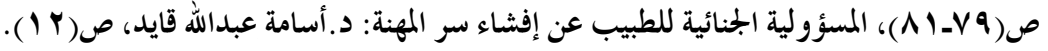

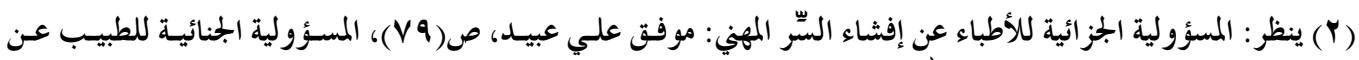

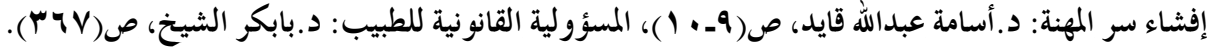

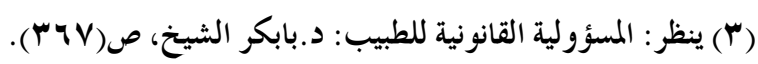

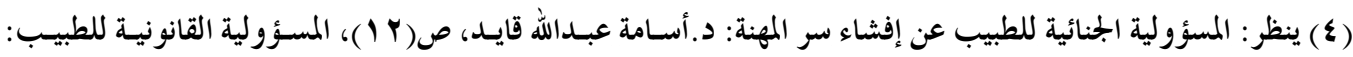

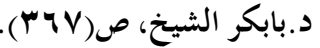

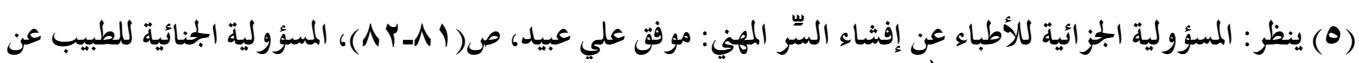

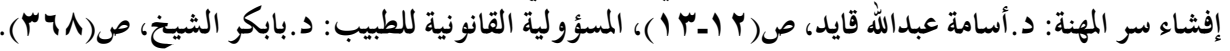




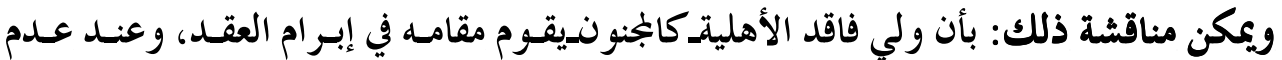

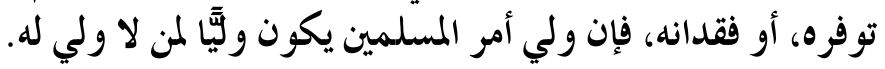

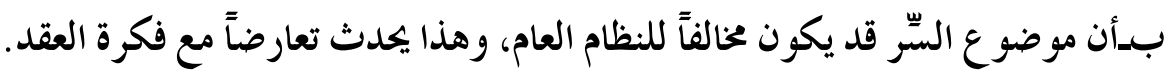

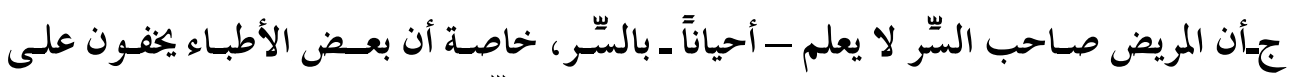

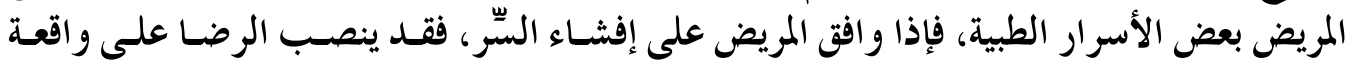

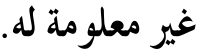

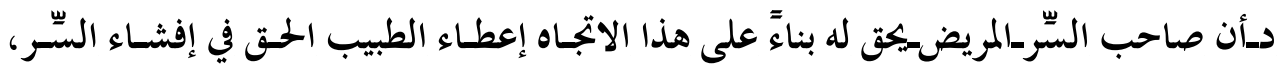

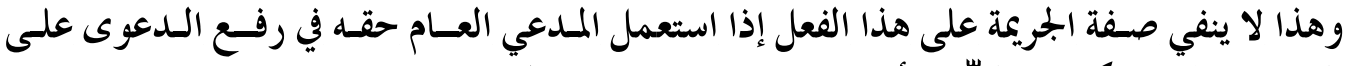

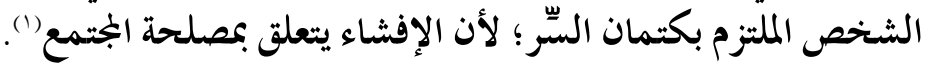

"الاتجاه الثاني: أن أساس الالتزام بالسِّ الطبي هو النظام العام(؟).

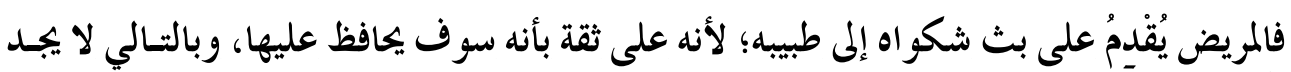

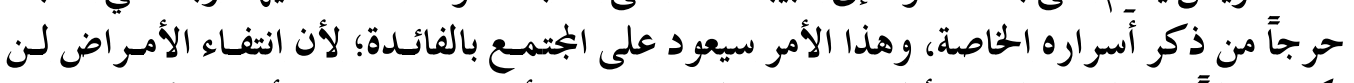

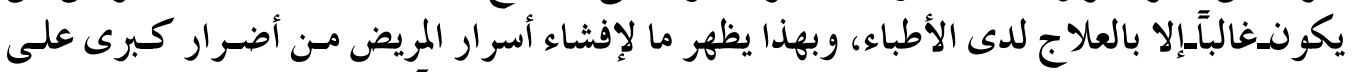

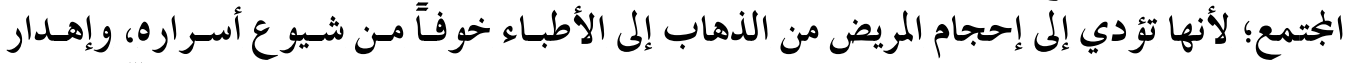

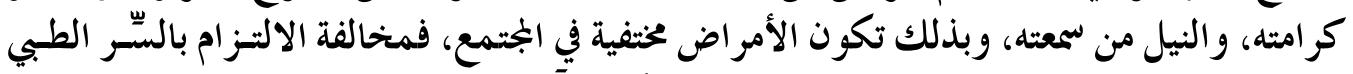

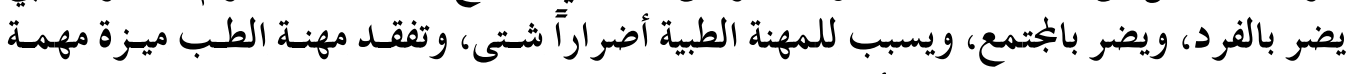

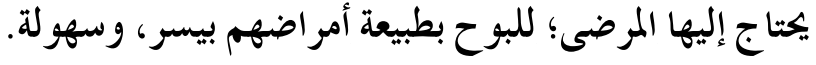

\section{ومما يتزتب على القول بهذا الاتجاه ما يأتي (r):}

أـأن السِّر الطبي واجب مطلق، ومستمر، فالطبيب لا يحق له إفشاء السِّ بصورة مطلقة، ولو

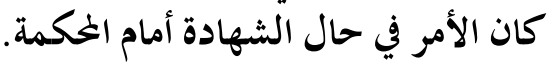

$$
\text { بـلا يحق للمريض أن يعفي الطبيب من التزامه بكتمان السِّ الطبي. }
$$

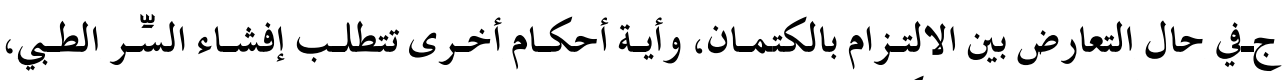
فيجب على الطبيب الالتز ام بالكتمان.

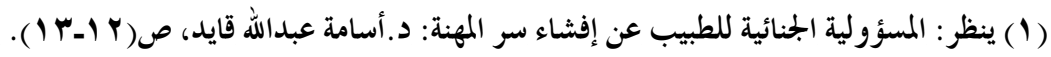

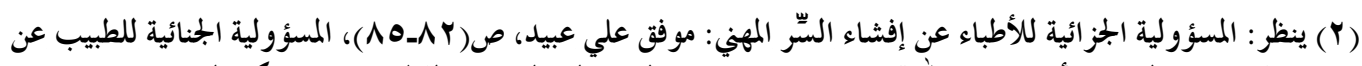

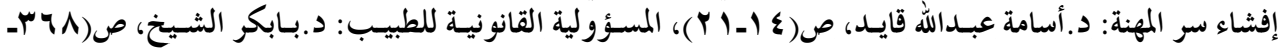

. (rV.

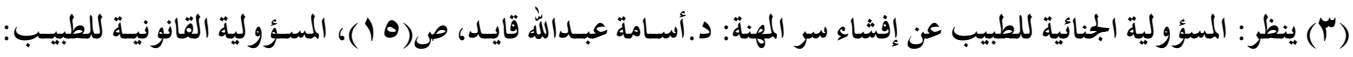

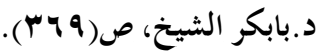


ديعتبر إفشاء السِّر الطبي جُرْماً حتى لو كان الأمر في سبيل دفاع الطبيب عن نفسه.

ومما يؤخذ على هذا الاتجاه ما يأتي (1):

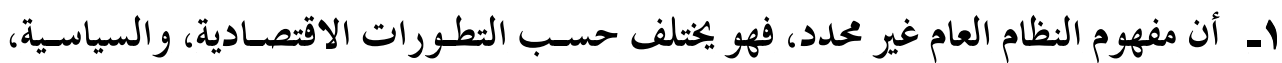

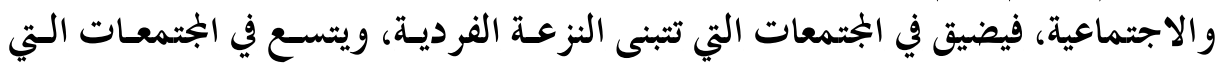

$$
\text { تتبنى النزعة الجمماعية. }
$$

Y. ـ أن هذا الاتجاه يعطي الطبيب الحتق في الإفلات مـن المسؤولية عـن أخطائسه المهنيـة بالتزامـه.

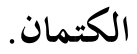

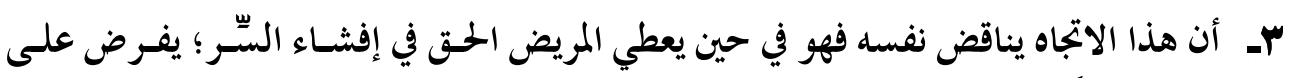

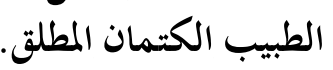

"الاتجاه الثالث: أن أساس الالتزام بالسِّر الطبي هو المصلحة).".

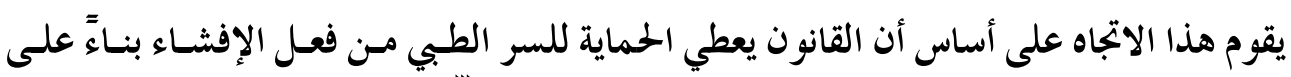

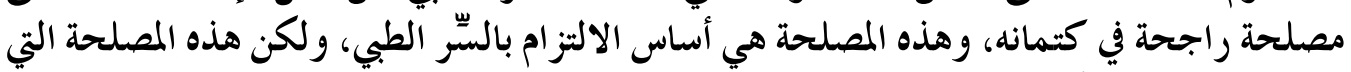

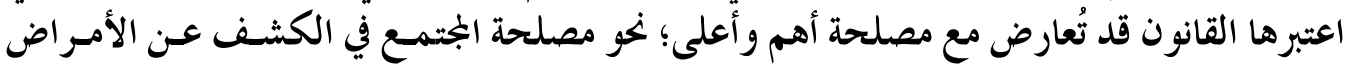

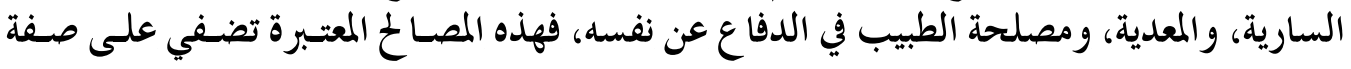

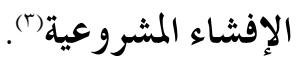

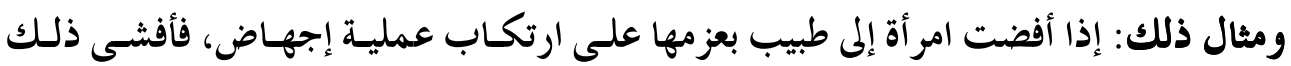

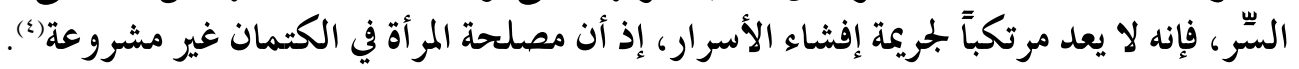

\section{ومما يؤخذ على هذا الاتجاه (o)}

أن ضابط الموازنة بين المصالح المتعارضة بالإفشاء، أو الكتمان، غير محددة، ثـم مسن الذذي يقوم

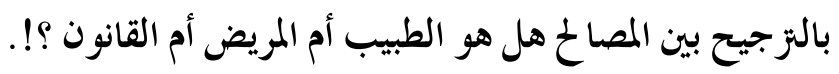

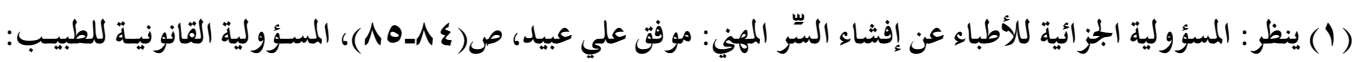

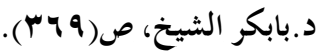

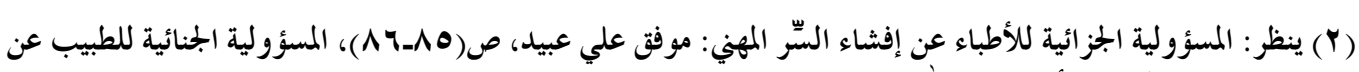

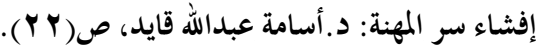

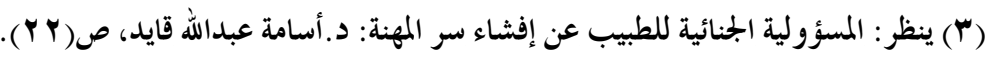

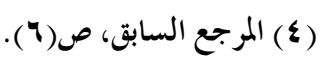

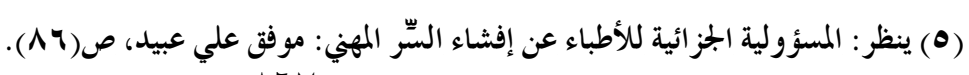
- NTV _ 
"الاتجاه الرابع: أن أساس الالتزام بالسِّّ الطبي أصبح عديم الأهمية؛ لكون السِّّ الطبي أصسبح

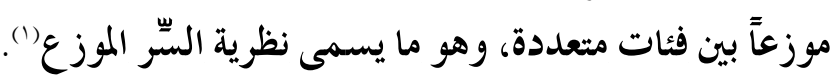

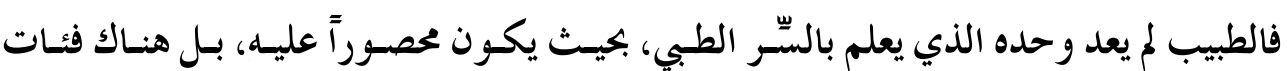

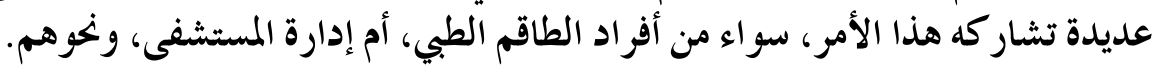

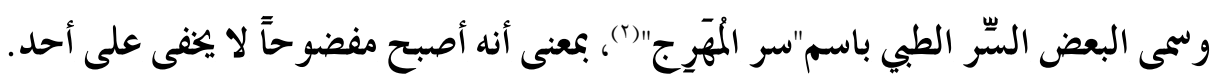
و أمام هذه التطورات ذهب البعض إلى القول أن أهمية السِّّ الطبي أصبحت غير ذات فعالية.

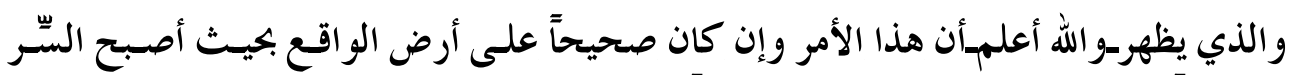

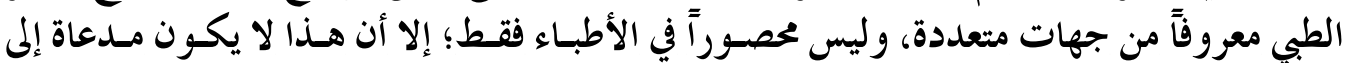

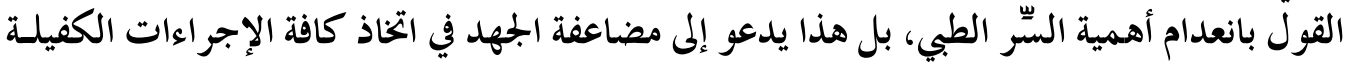

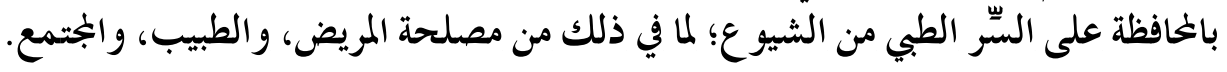

*الاتجاه الحخامس: أن أساس الالتزام بالسِّر الطبي هو كونه دعامة لمهنة الطب(").

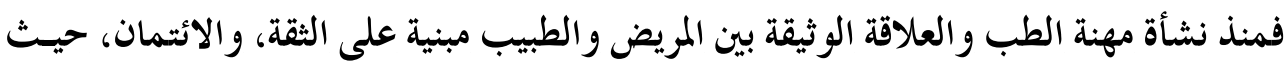

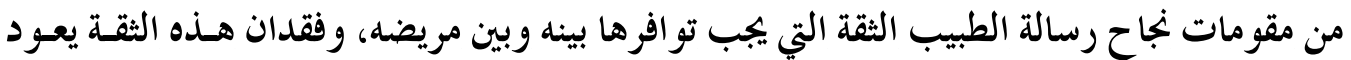

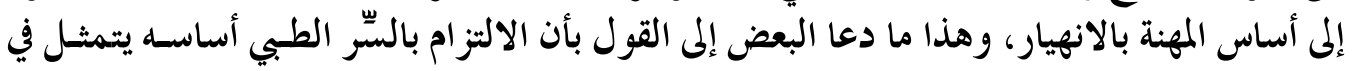

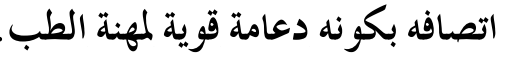

$$
\text { الزجيح: }
$$

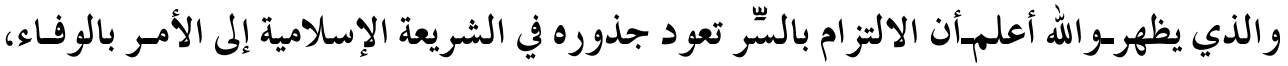

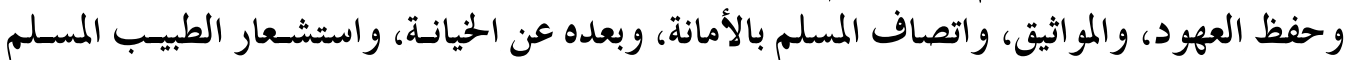

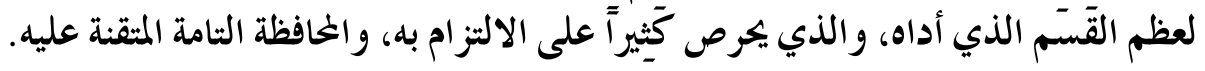

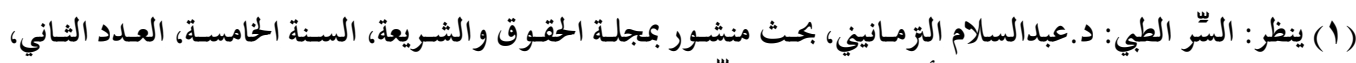

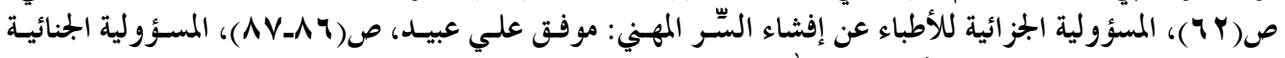

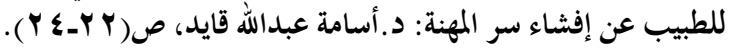

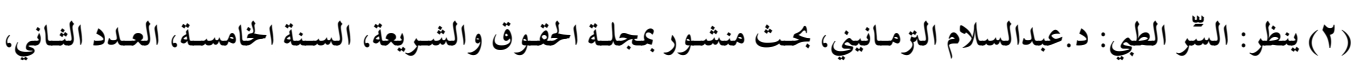

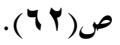

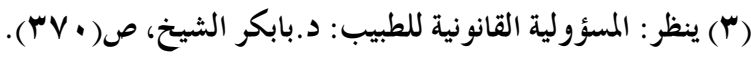
- ᄉ५ - 


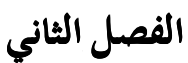 \\ تعريف كتمان السّّر، وبيان فضله، وحكمه \\ المبحث الأول \\ تعريف كتمان السّر .}

$$
\text { أ أ تعريف الكت : تعريف الكتمان. }
$$

قال ابن فارس- رحمه الله -: "الكاف، و التاء، والميم، أصلٌ صحيح لُيدل على إخفاء، وستز "(؟).

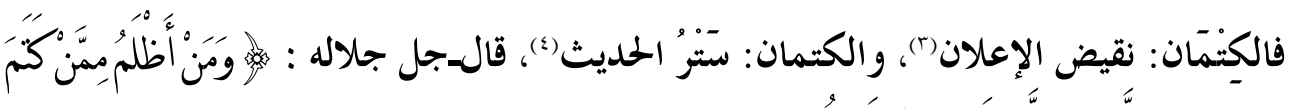

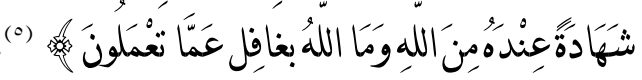

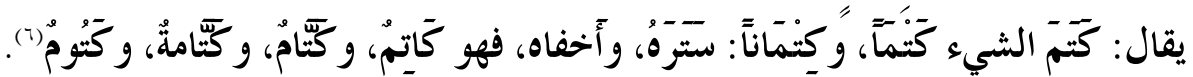

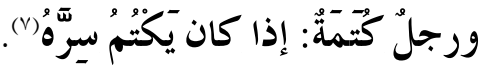

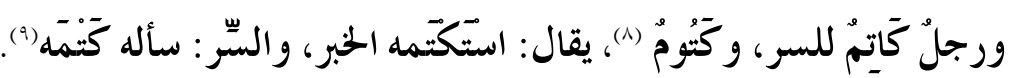

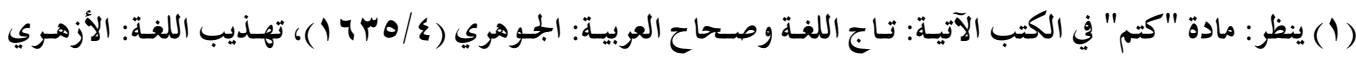

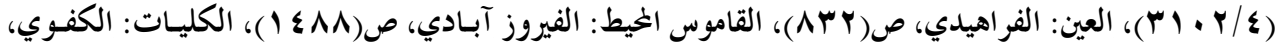

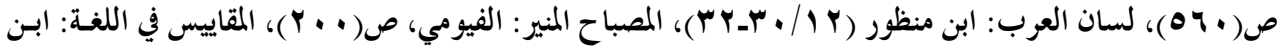

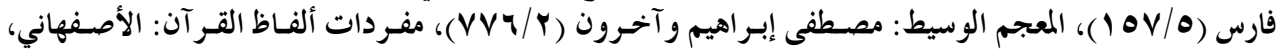
ص ص (

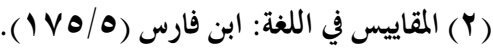

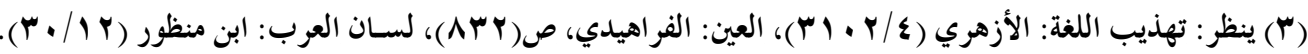

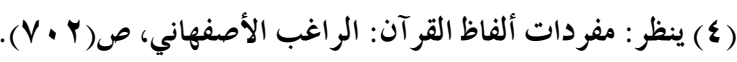

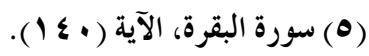

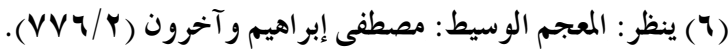

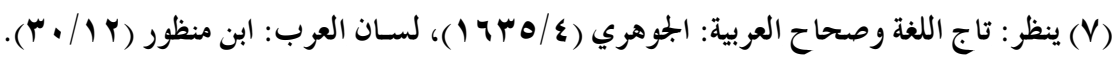

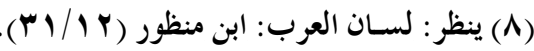

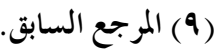




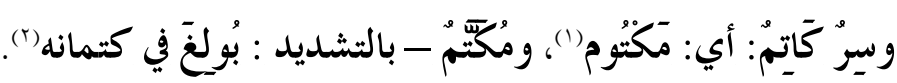

$$
\begin{aligned}
& \text { ب ـ تعريف الكتمان اصطلاحاً. } \\
& \text { للكتمان عدة تعريفات عند الفقهاء منها: } \\
& \text { 1- الكتمان: "السكوت عن البيان"(؟). }
\end{aligned}
$$

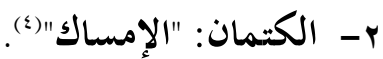

فلا يخرج معنى الكتمان في اصطلاح الفقهاء عن معناه اللغوي(')، فالكتمان هو إخفـاء الثـيء،

ثانيـاً: تعريف كتمان السِّر.

$$
\text { يعرف كتمان السِّر بأنه: "عدم إفشاء ما ينبغي إسراره"((). }
$$

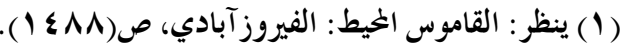

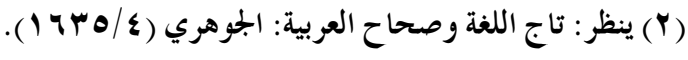
(r) الموسوعة الفقهية: إصدار وزارة الأوقاف والشئون الإسلامية بالكويت ( ع • V ) .

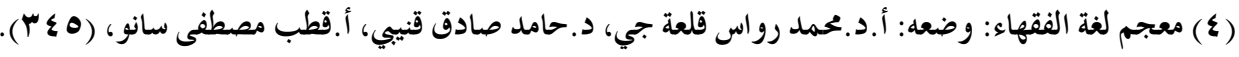

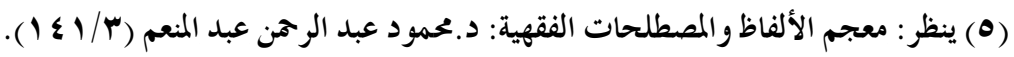

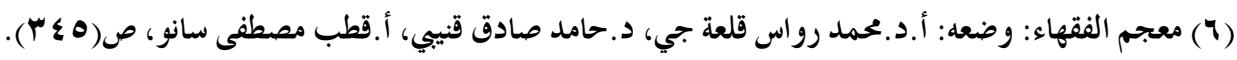
- $\Lambda V$. 


\section{المبحث الثاني \\ فضل كتمان السِّر}

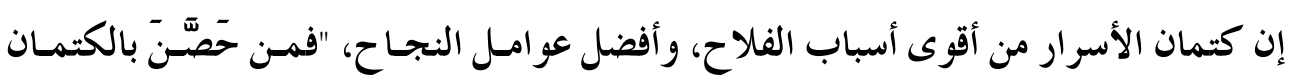

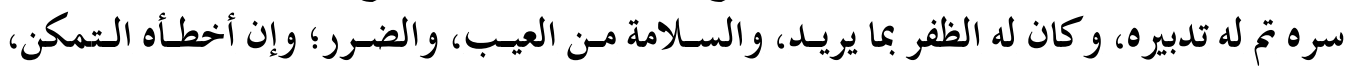

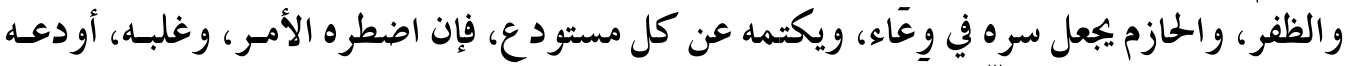

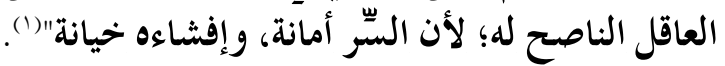

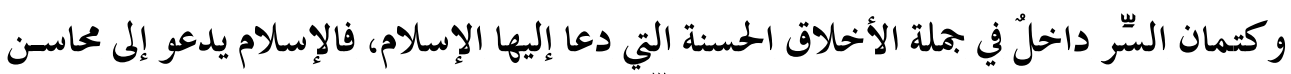

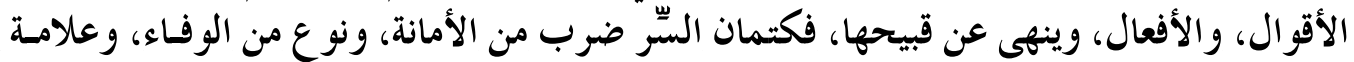

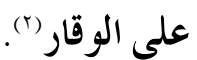

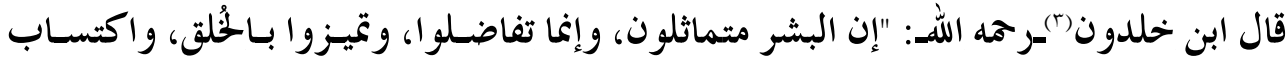

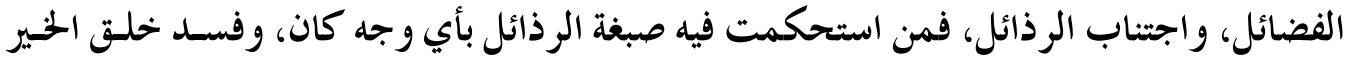

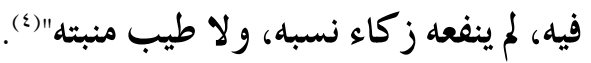
ومما يدل على فضيلة كتمان السّرّ، ما يأتي:

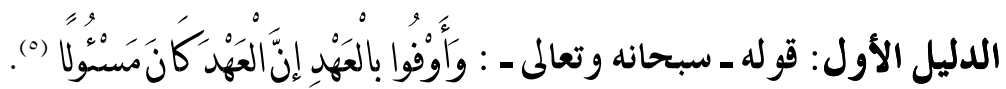

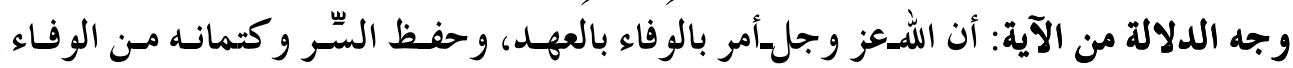

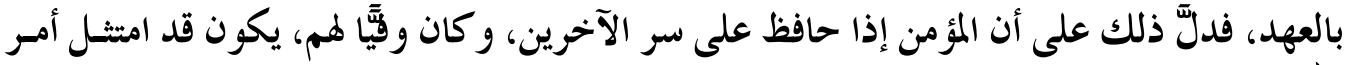

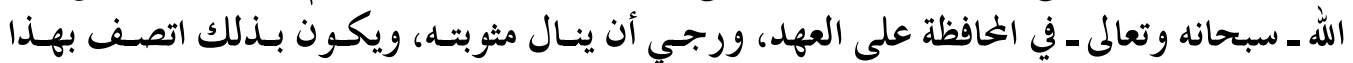

$$
\text { (1 ) روضة العقلاء ونزهة الفضلاء: محمد بن حبان البستي، ص(IVY) . }
$$

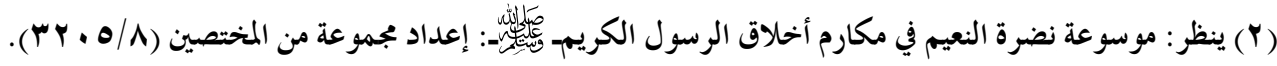

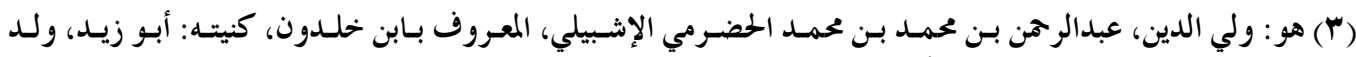

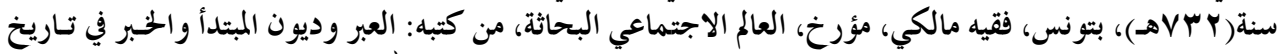

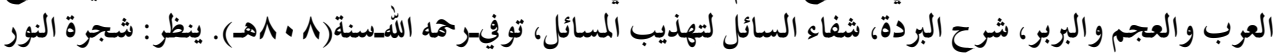

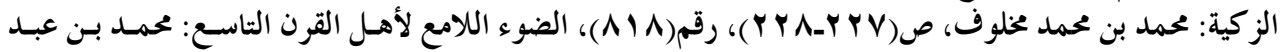

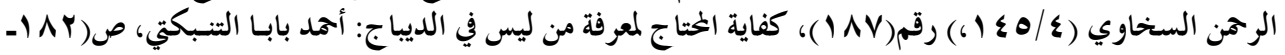




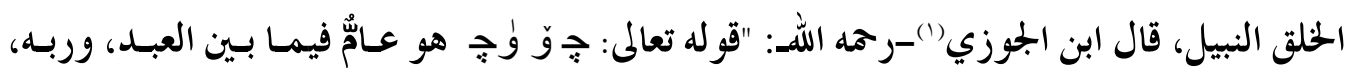

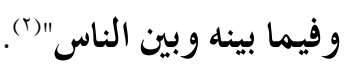

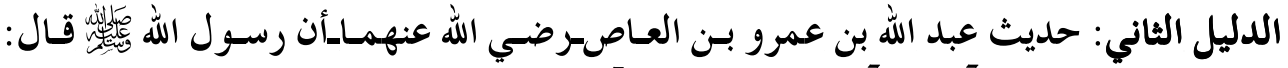

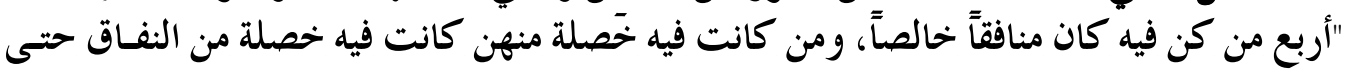

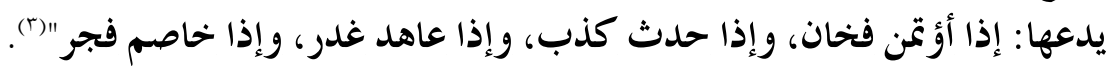

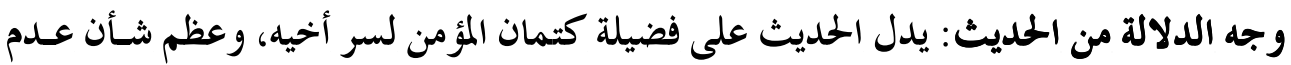

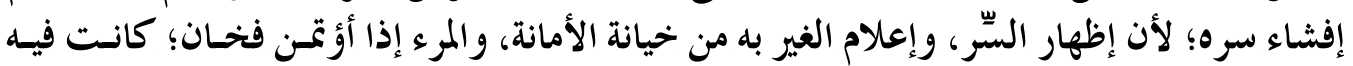

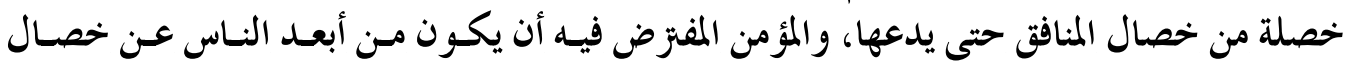
النفاق، حريصاً على الخلقى الفاضل النبيل.

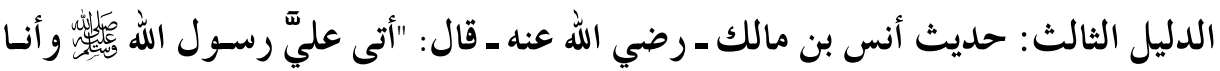

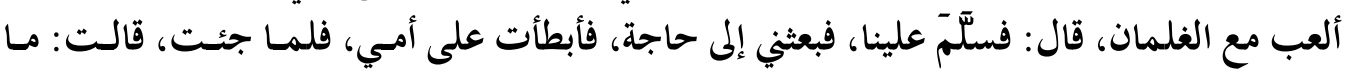

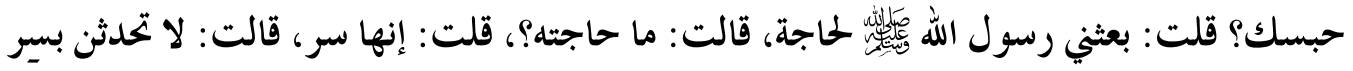

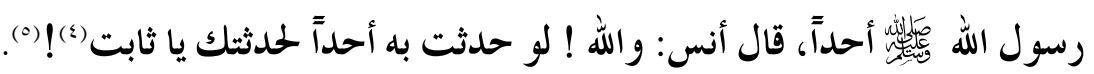

وجه الدلالة من الحديث: يدل الحمديث على عظم شأن حفظ السِّرَ، وعلـو مكانتسه، فقـــ كـان

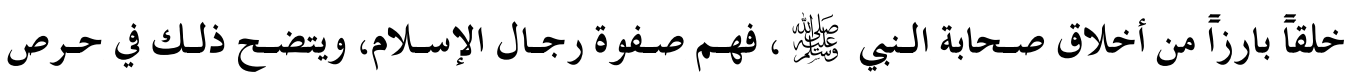

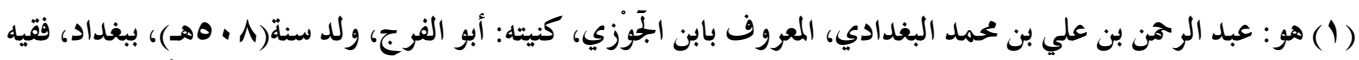

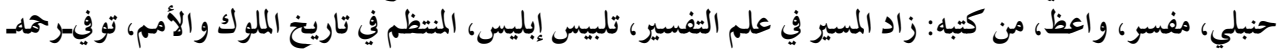

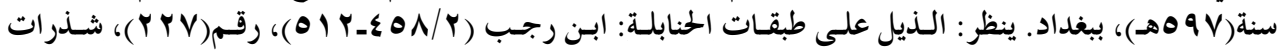

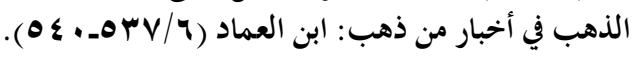

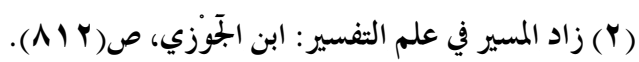

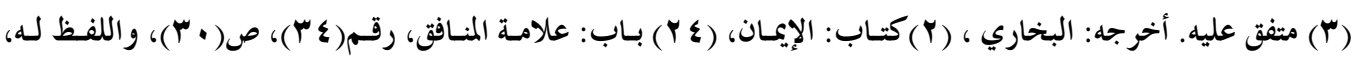

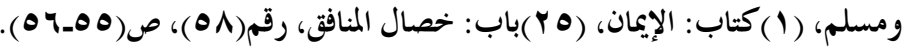

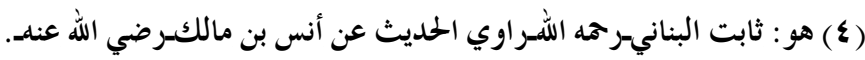

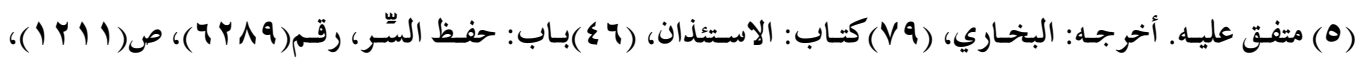

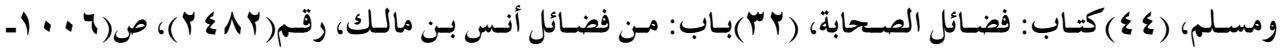




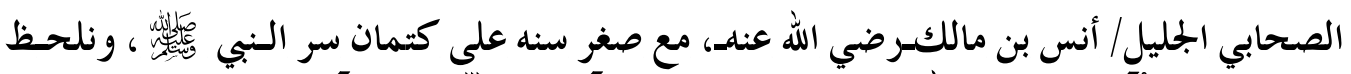

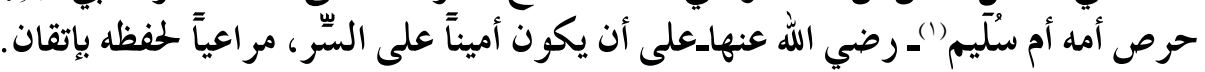

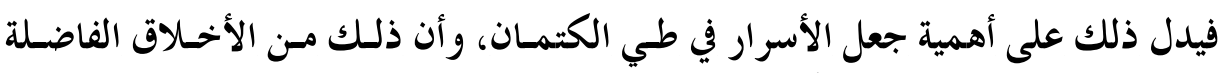

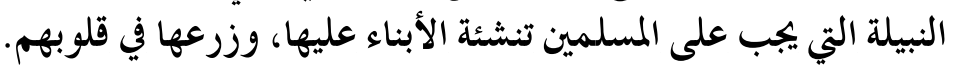

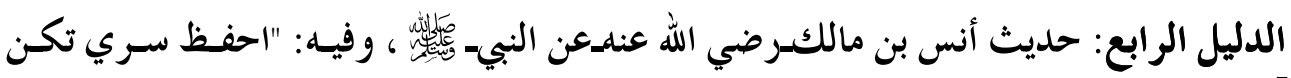

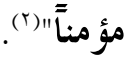

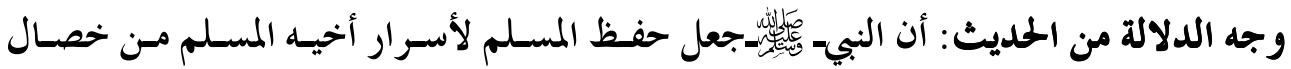

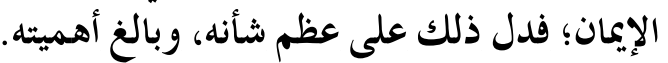

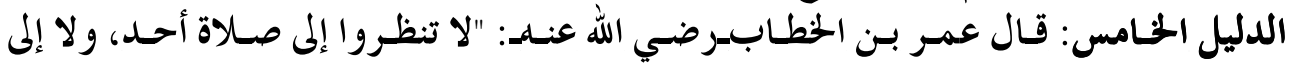

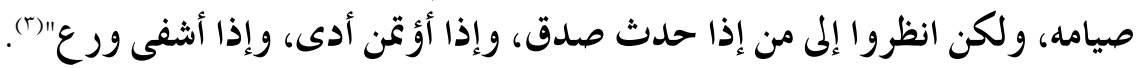

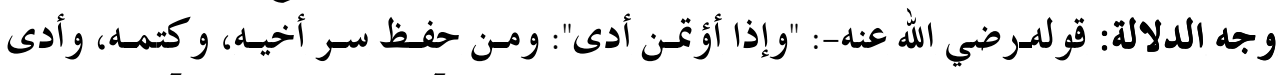

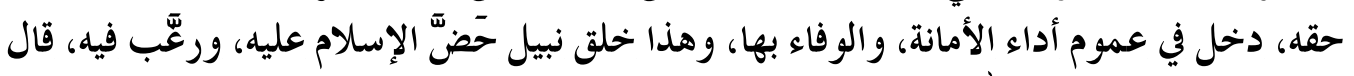

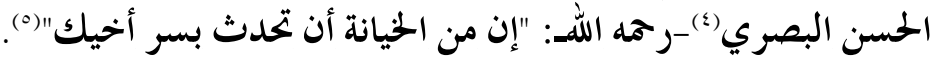

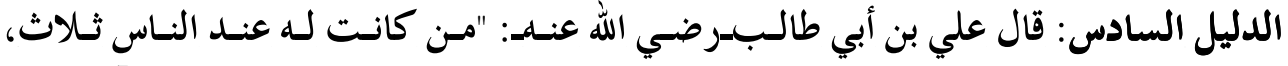

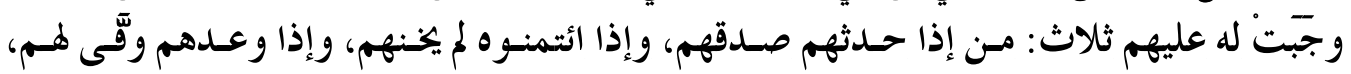

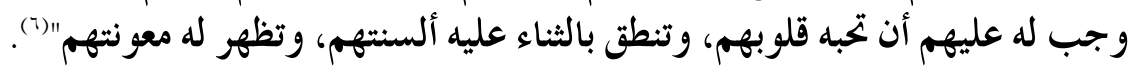

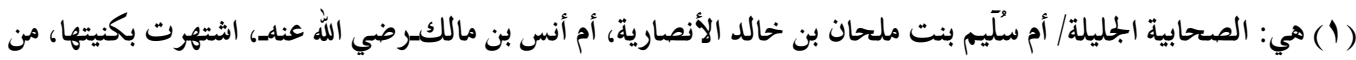

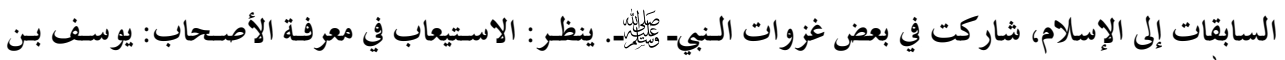

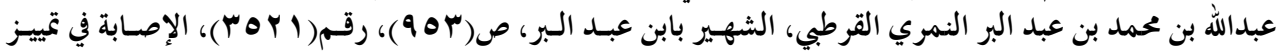

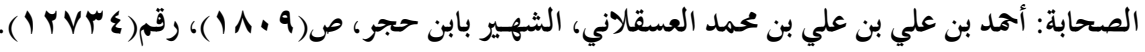

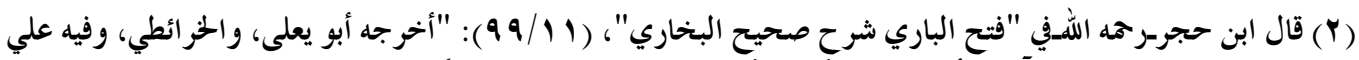

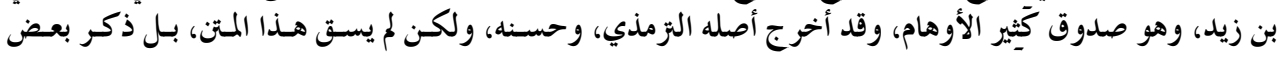

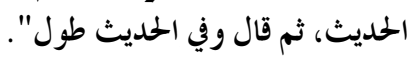

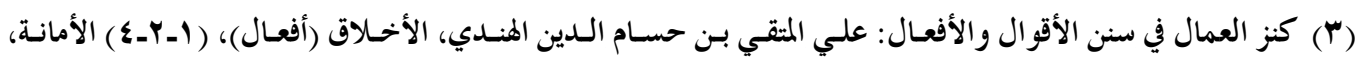

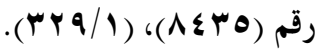

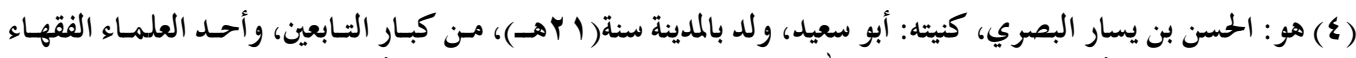

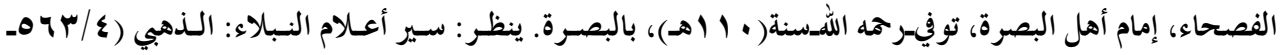

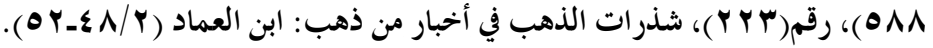

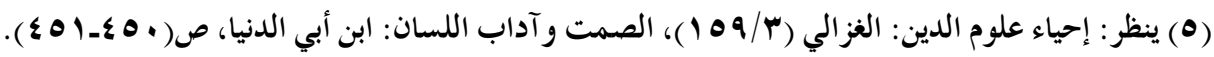
$-\Lambda V r-$

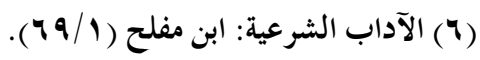




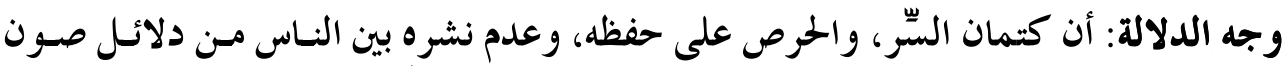

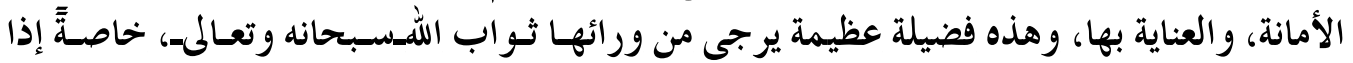

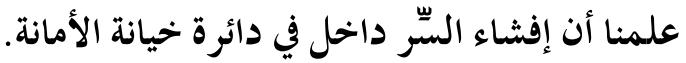

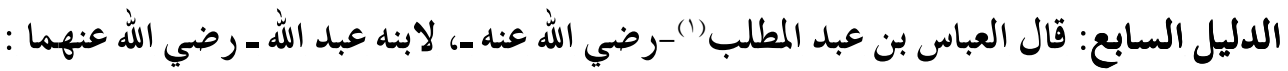

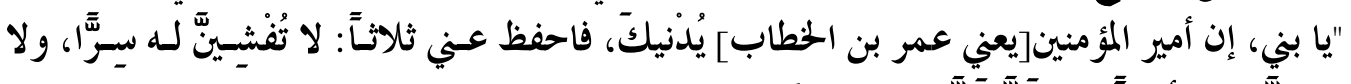

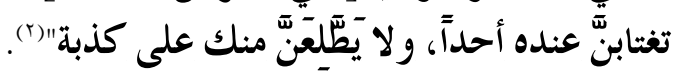

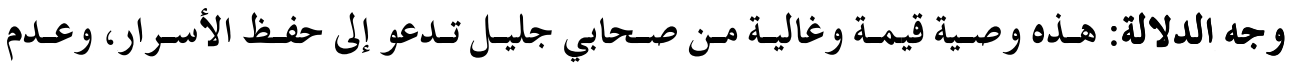

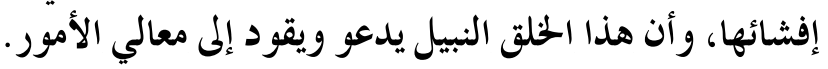

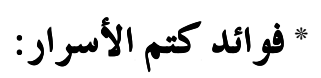

\section{يمكن إيضاح فوائد كتم الأسرار في النقاط الآتية(r):}

ا. . أن كتمان السِّ يؤدي إلى قضاء مصالح الإنسان، ومو اجهة الصعاب المتعددة التي تو اجهه.

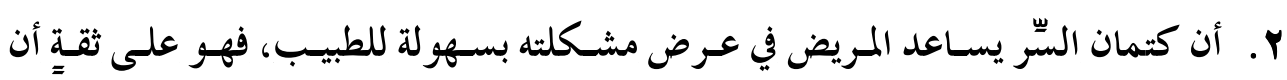

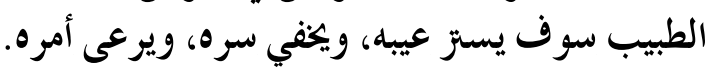

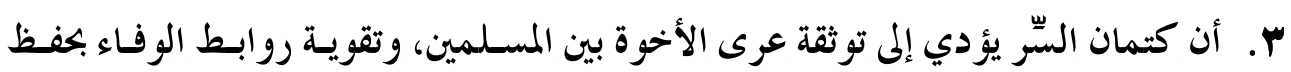

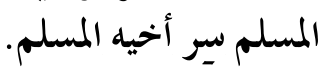

ع. أن كتمان السِّر فضيلة إنسانية بها يرتقي المرء في درجات الكمال.

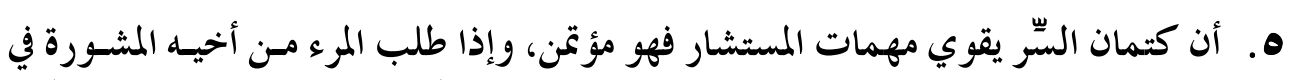

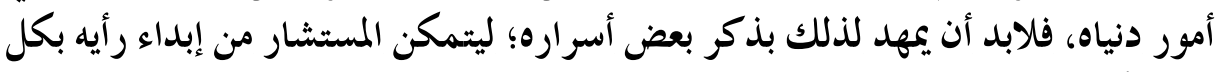
ثقة، و أمانة.

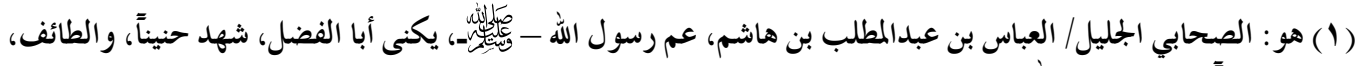

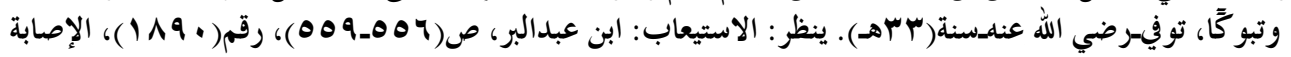

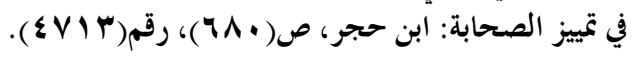

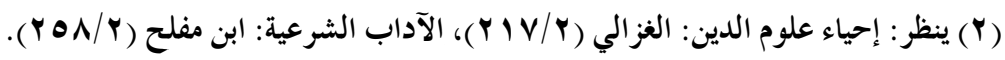

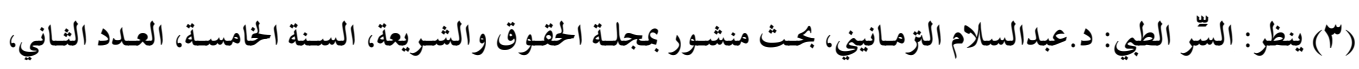

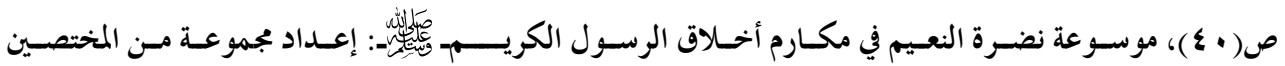




\section{المبحث الثالث \\ حكم كتمان السّر}

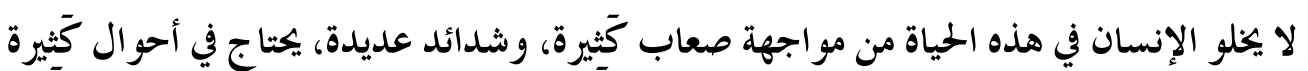

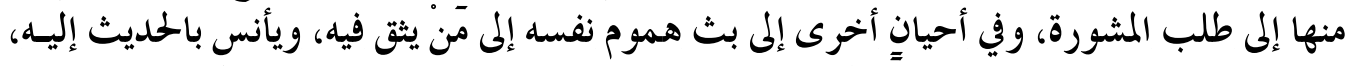

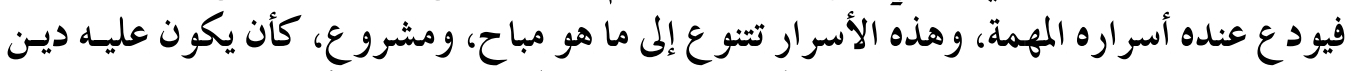

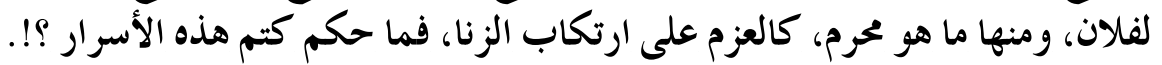
فيما يأتي تفصيل ذلك:

$$
\text { القسم الأول: الأسرار المباحة. }
$$

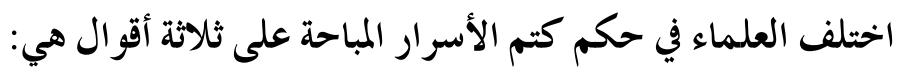

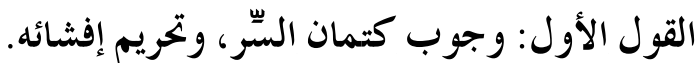

$$
\begin{aligned}
& \text { وإليه ذهب جمعُ من أهل العلم. }
\end{aligned}
$$

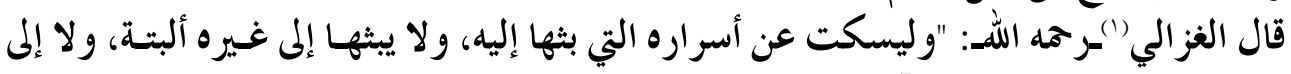

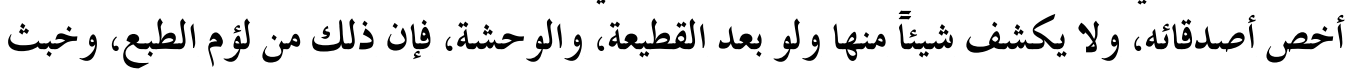
الباطن" (T) (1).

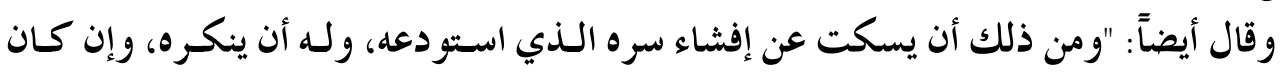

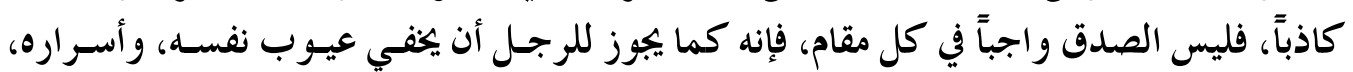

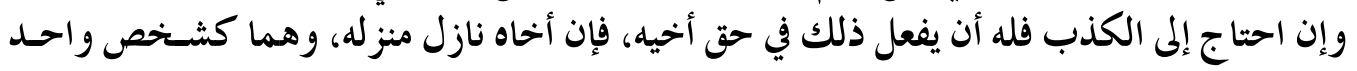
لا يختلفان إلا بالبدن"()". وقال ابن مفلح(s)-رمه اللهـ: " يجب حفظ سر من يلتفت في حديثة حذراً من إشاعثه؛ لأنه

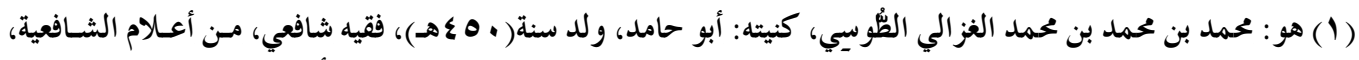

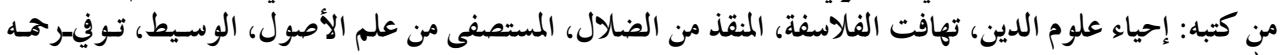

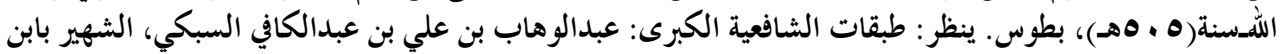

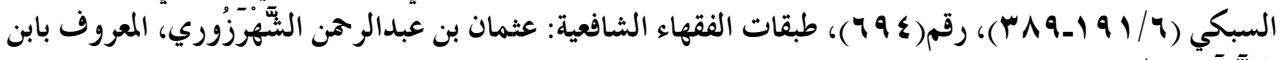

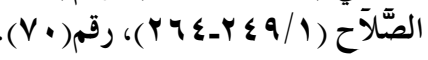

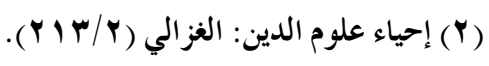

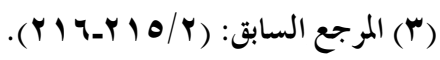

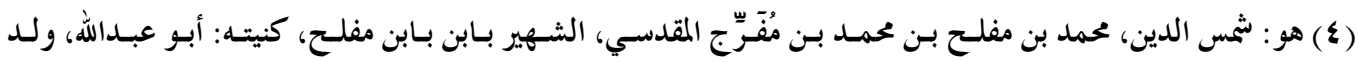

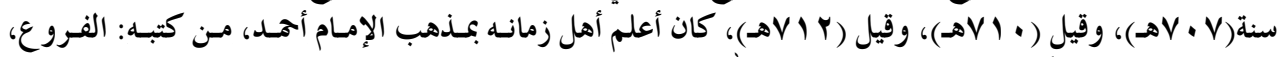

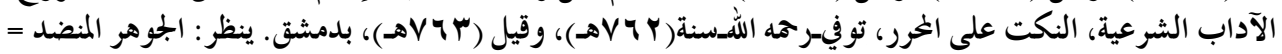

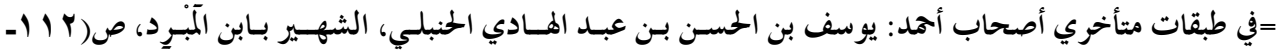

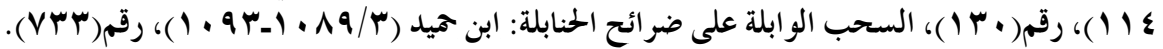




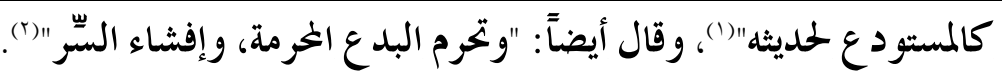

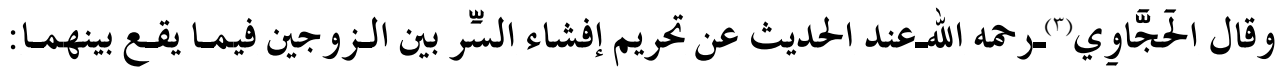

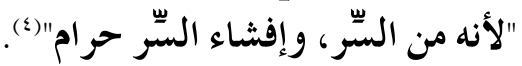

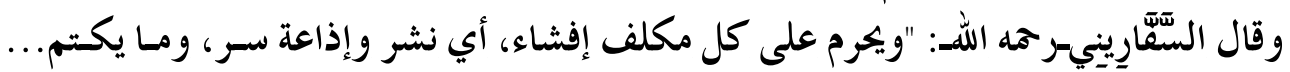

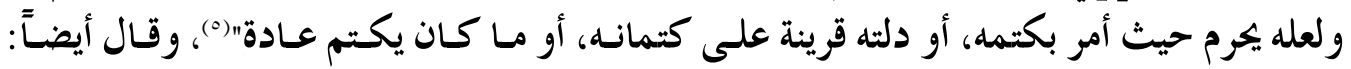
"و الحاصل أن على العاقل كتمان السِّر" (ج).

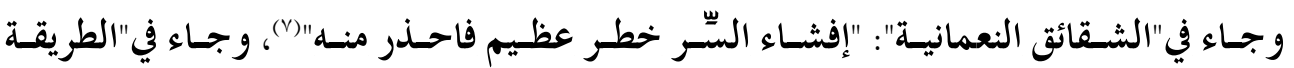

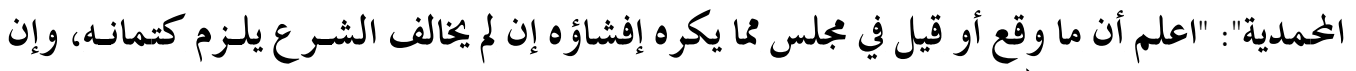

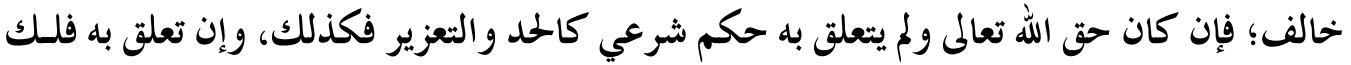

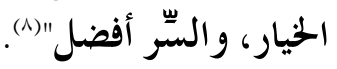

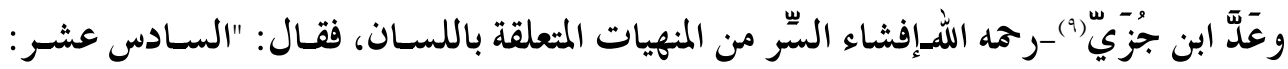

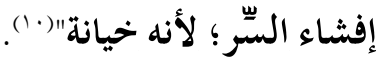

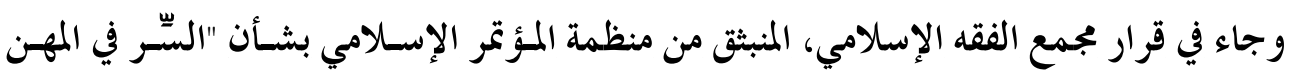

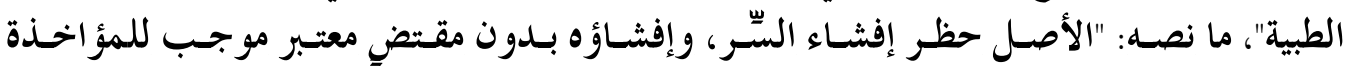

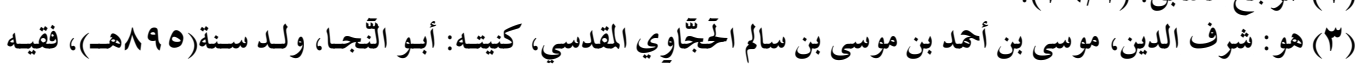

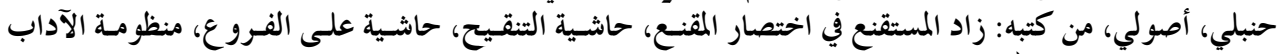

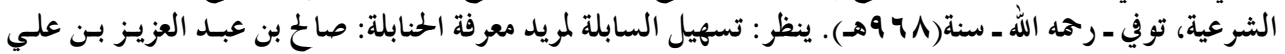

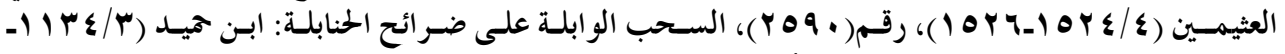

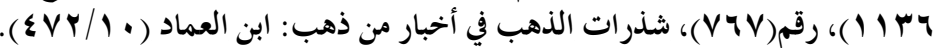

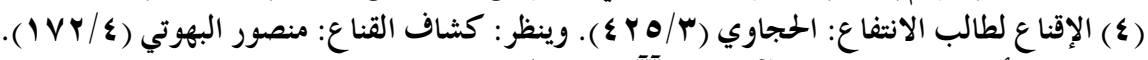

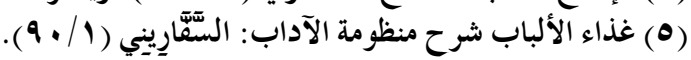

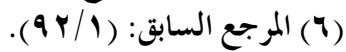

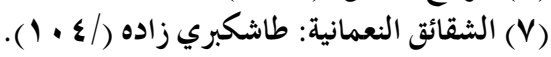

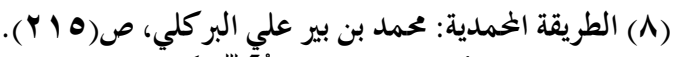

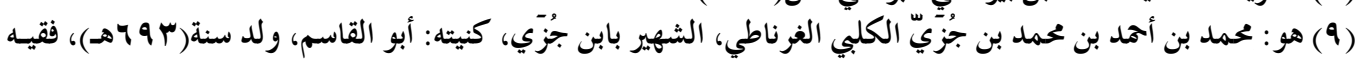

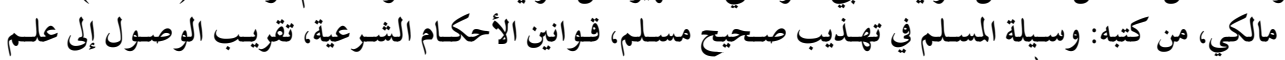

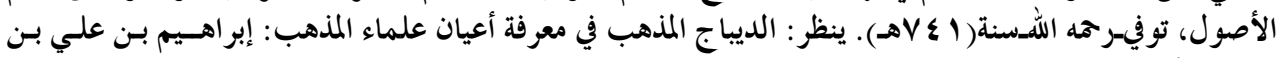

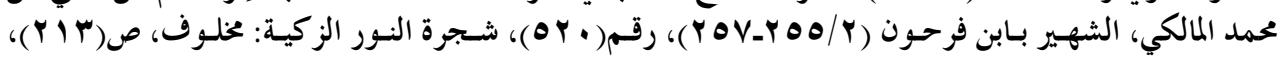

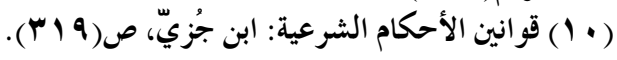

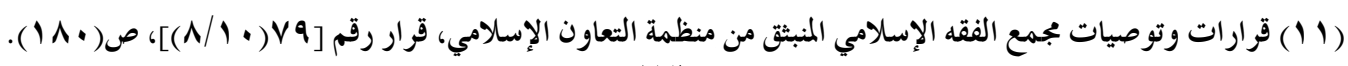
- AVT - 
وجاء في"الدستور الإسلامي للمهنة الطبية": "حفظ أسرار الناس، وستز عوراتهم، واجـب على ألى

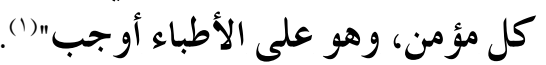

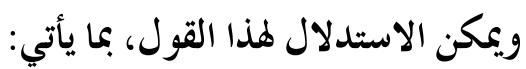

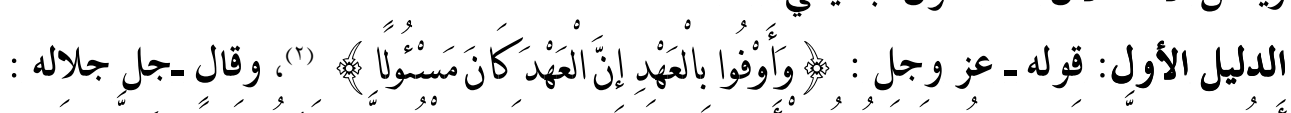

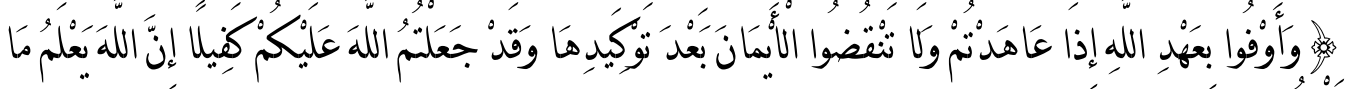

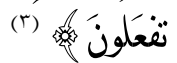

وجه الدلالة من الآيتين: أن الله ـ سبحانه وتعالى ـ أمر بالوفاء بالعهد، وحفظ السّرّ و كتمانه من

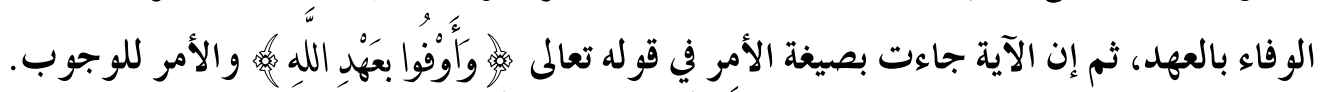

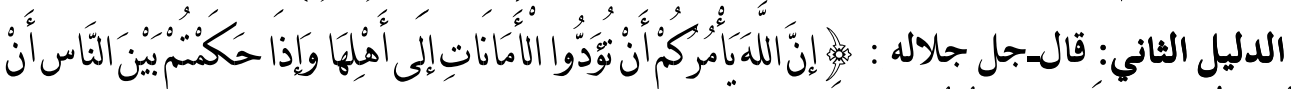

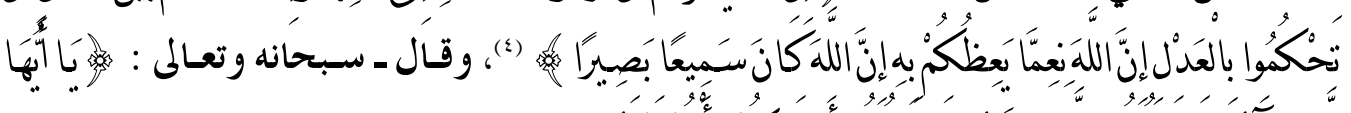

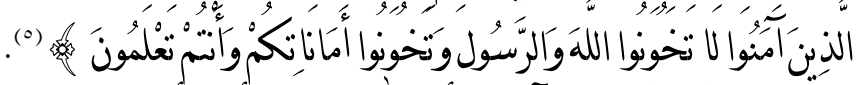

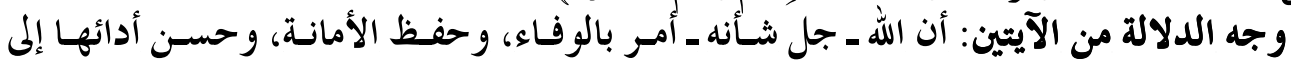

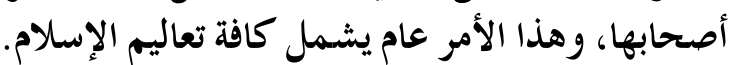

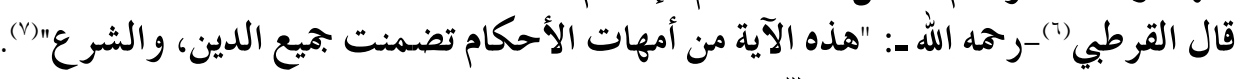

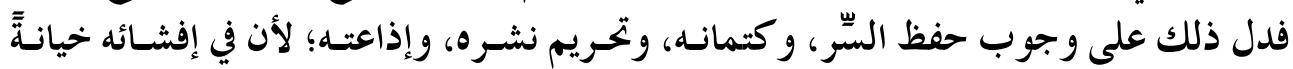
للأمانة.

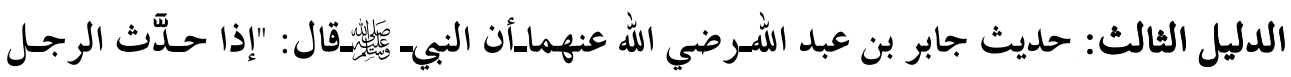

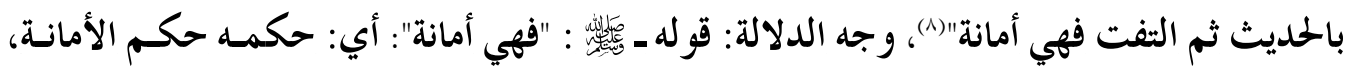
(1) أبحاث وأعمال المؤتمر العالمي الأول عن الطب الإسلامي: وزارة الصحة العامة، الجلس الوطني للثقافة والفنون والآداب،

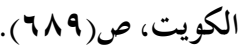

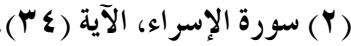

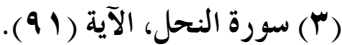

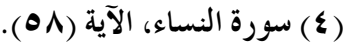

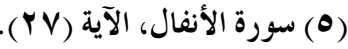

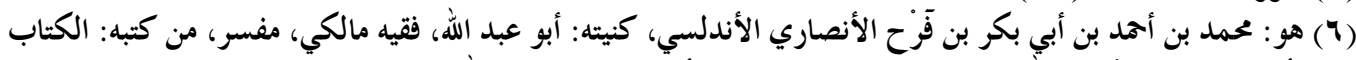

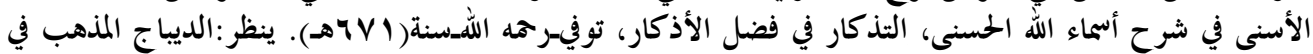

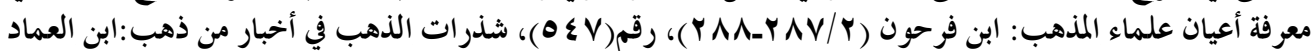

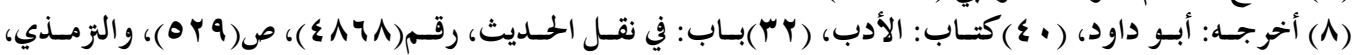

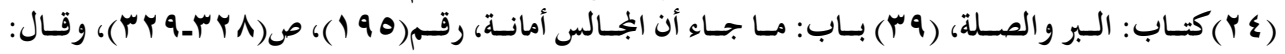

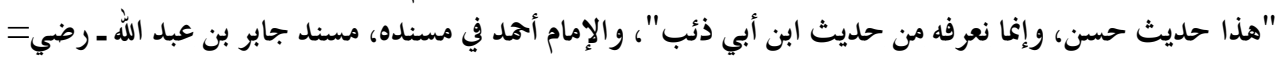




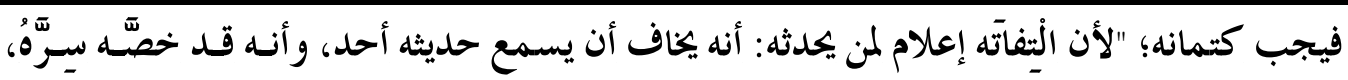

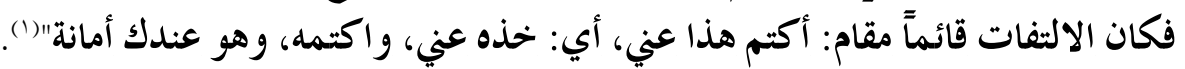

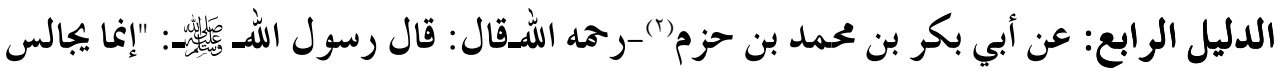

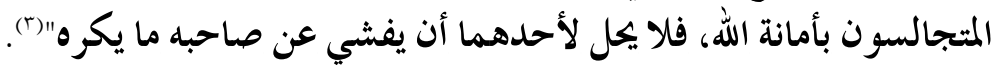

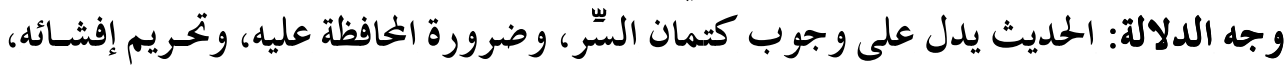

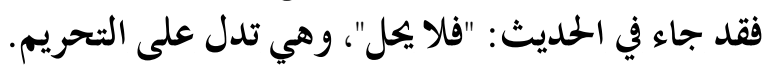

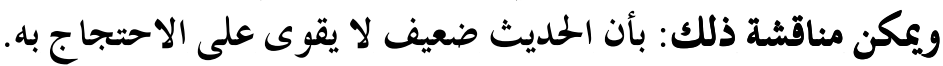

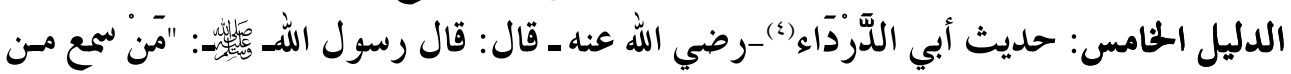

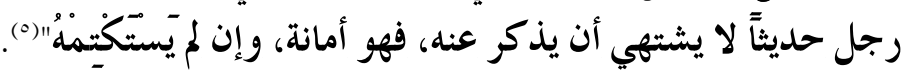

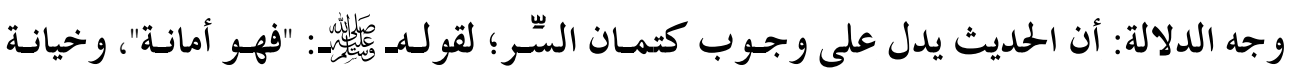

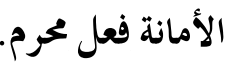

ويمكن مناقشة ذلك: بأن الحديث ضعيف لا يقوى على الاحتجاج به.

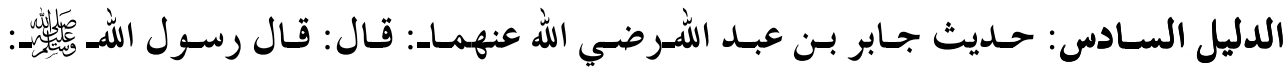

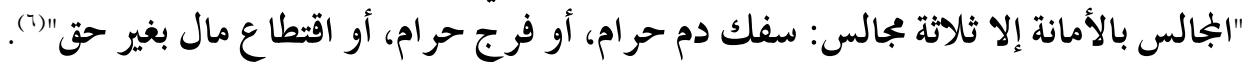

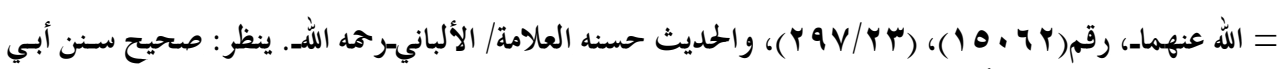

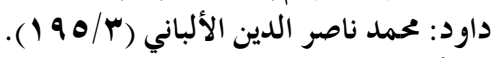

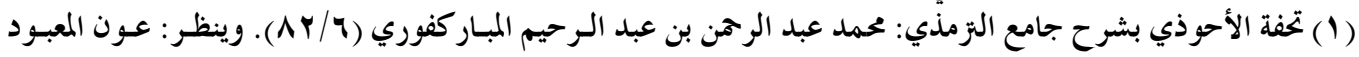

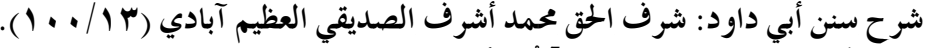

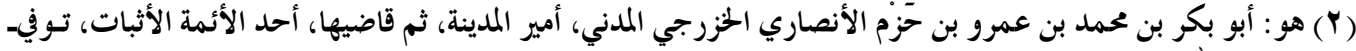

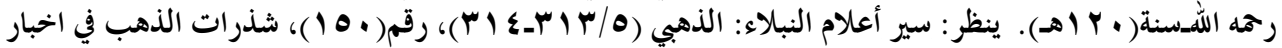
من ذهب: ابن العماد (r/ / / (q).

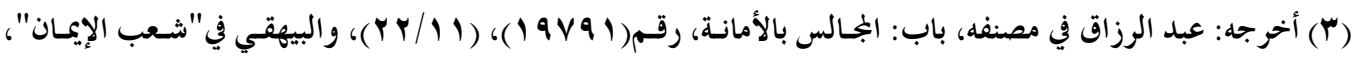

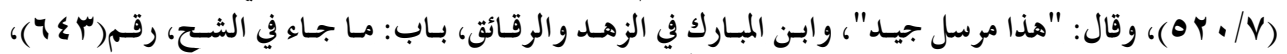

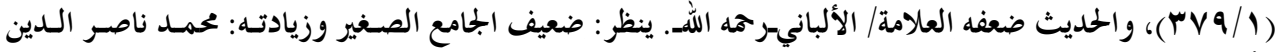

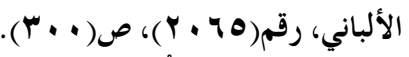

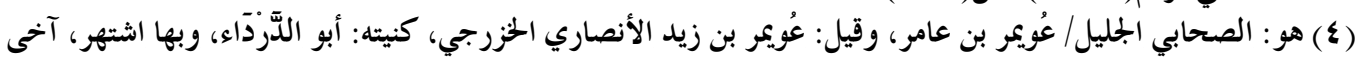

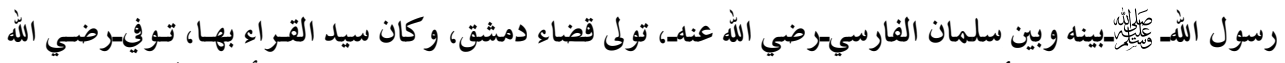

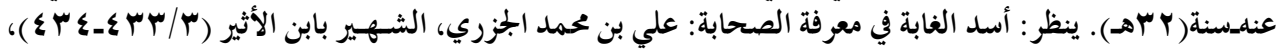

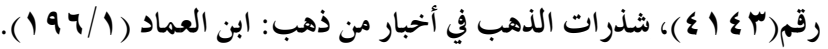

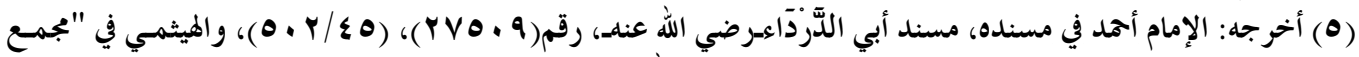

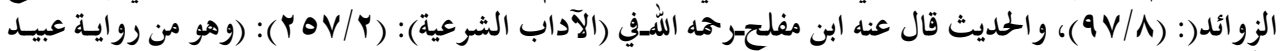

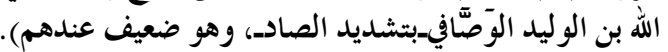

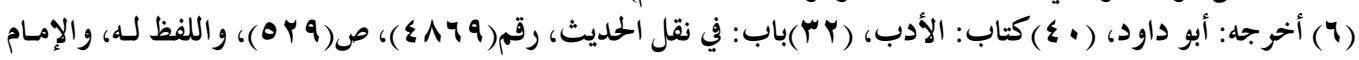

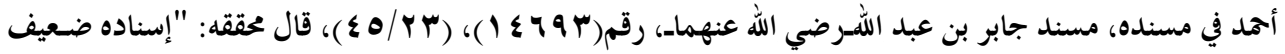

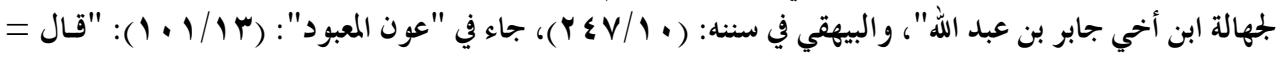




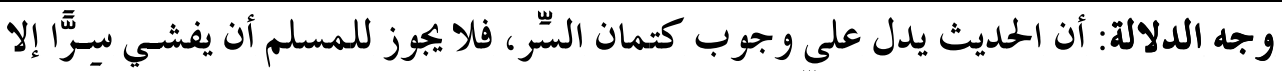

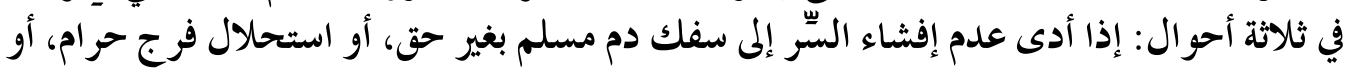

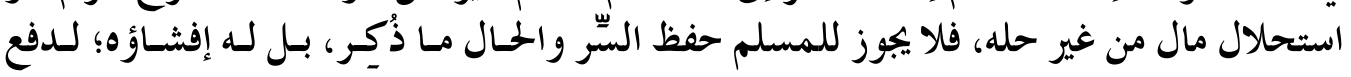

ويكن مناقشة ذلك: بأن الحديث ضعيف لا يقوى على الاحتجاج به.

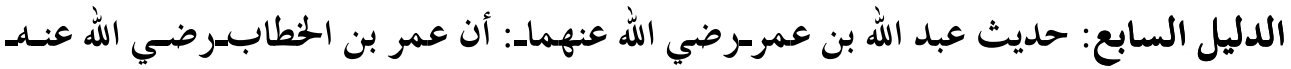

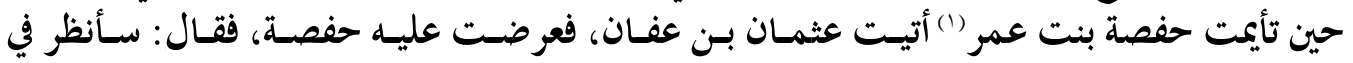

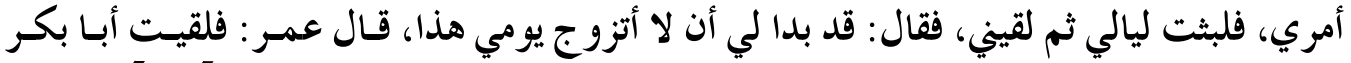

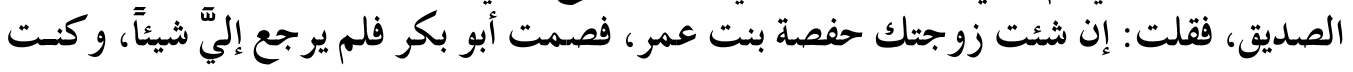

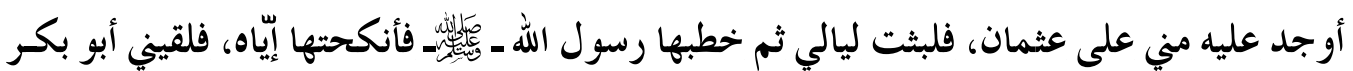

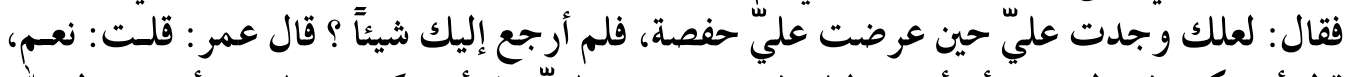

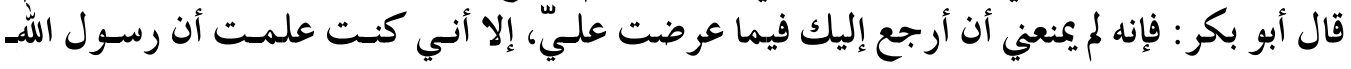

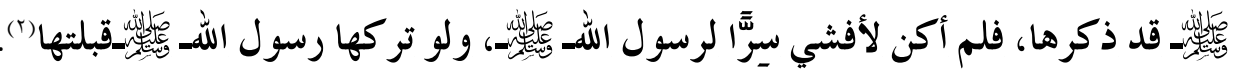

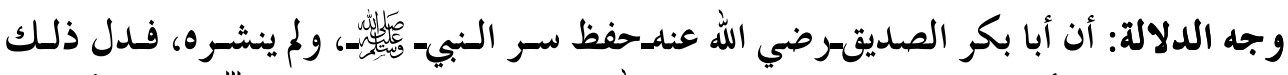

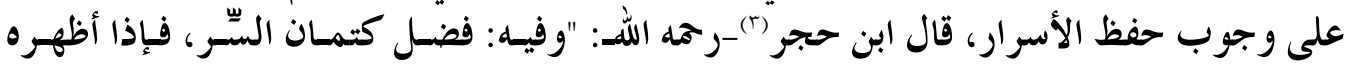

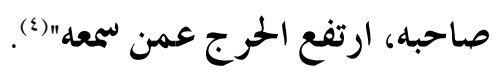

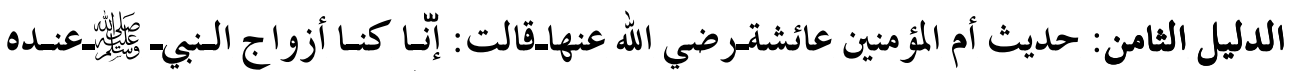

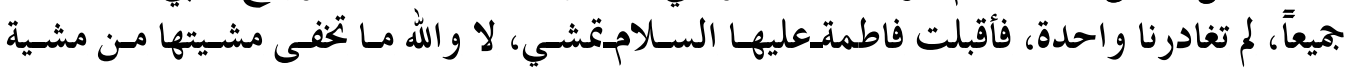

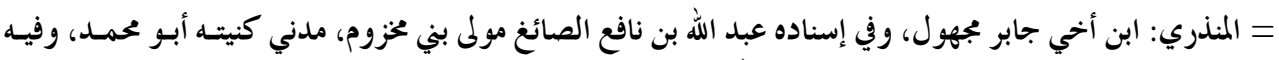

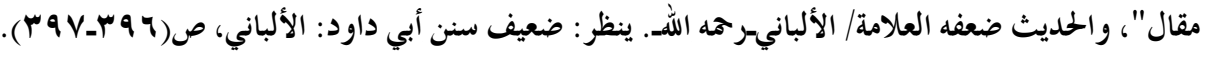

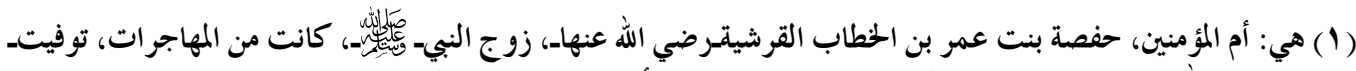

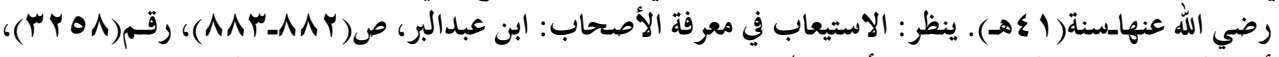

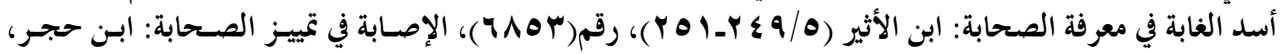

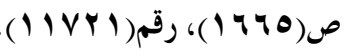

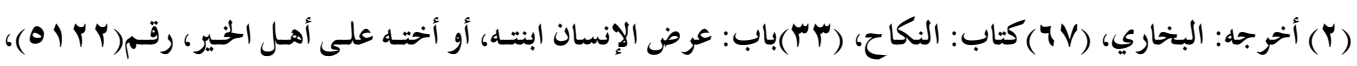

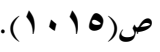

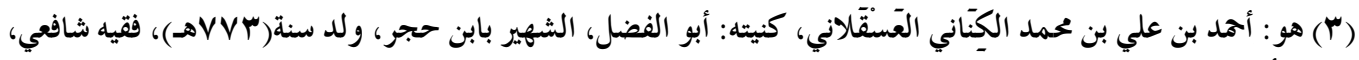

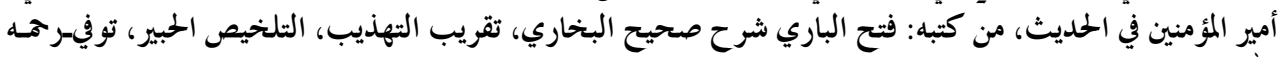

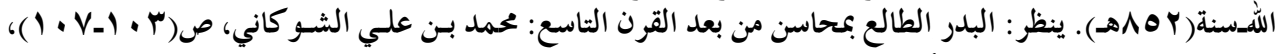

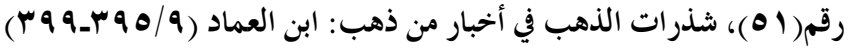

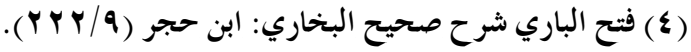




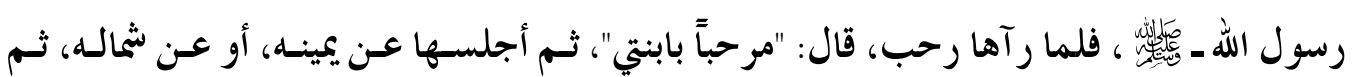

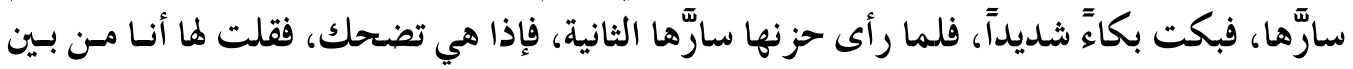

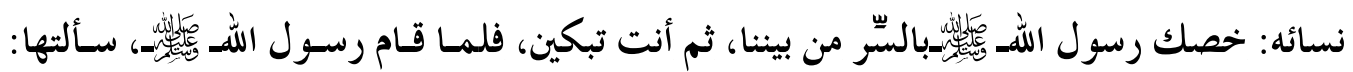

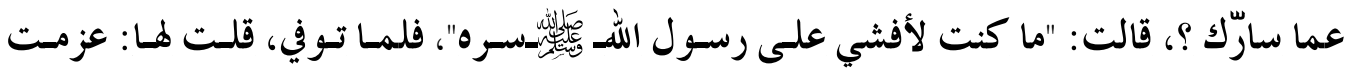

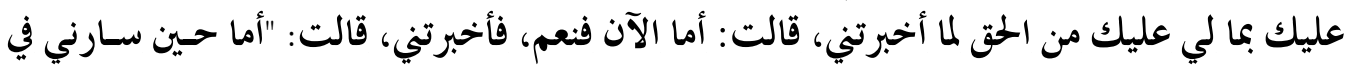

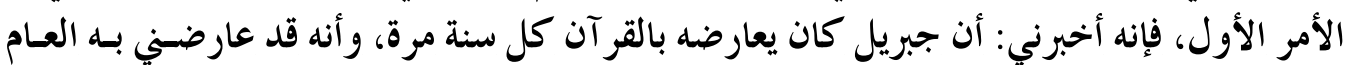

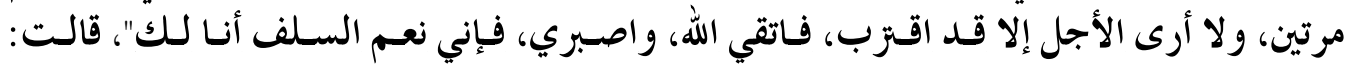

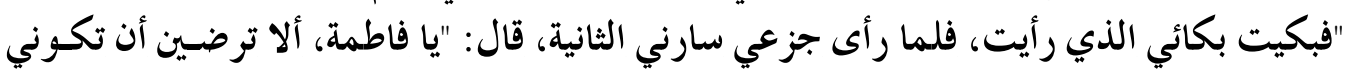

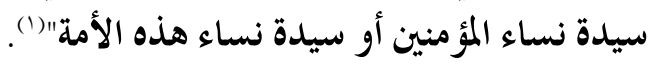

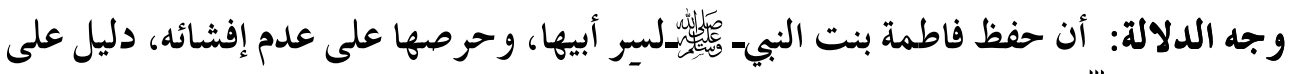
وجوب كتمان السِّ ، وتحريم إفشائه.

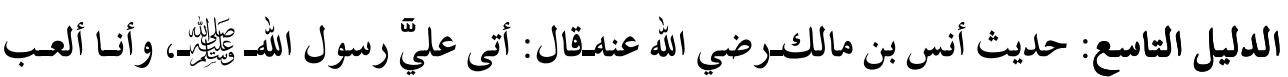

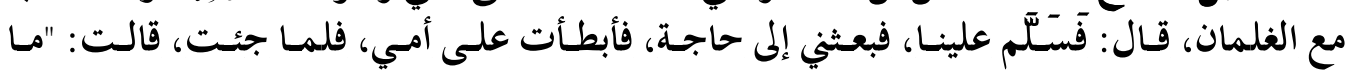

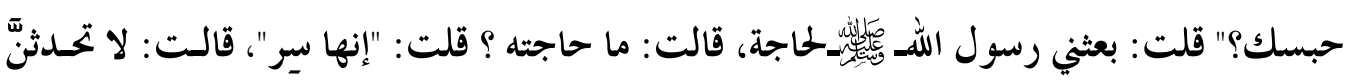

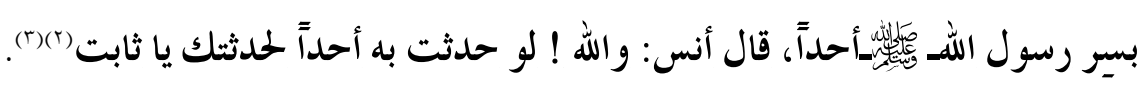

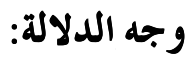

دل الحديث على وجوب كتمان السّرّ، وتحريم إفشائه، فأنس بن مالكـرضسي الله عنســحـرص

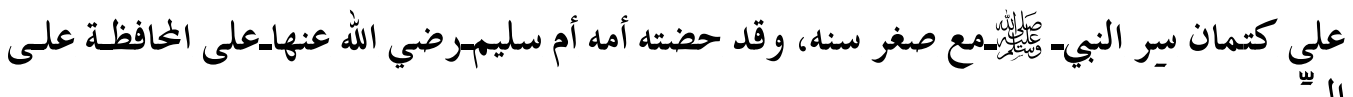

الدليل العاشر : أن إفشاء السِّر فيه خيانة للأمانة، وعدم الوفاء بالعهد (؛). القول الثاني: إباحة إفشاء السِّر إذا لم يكن في ذلك مضرة على صاحبه.

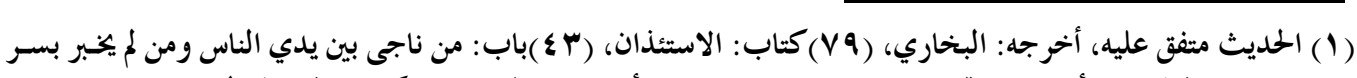

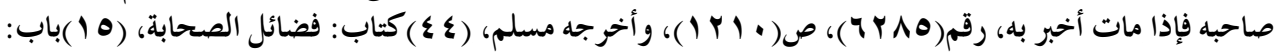

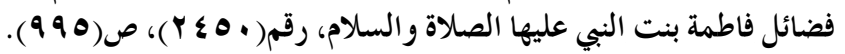

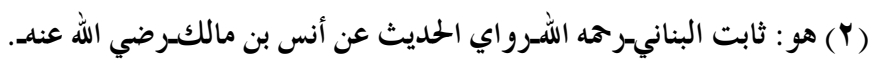
(ب) (ب) سبق تخريجه. $-\wedge \wedge \cdot-$ 


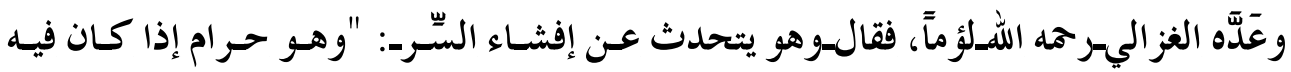

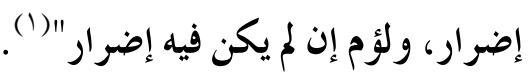

وقال ابن بَطَّال (ז) ـ رحمه الله : "الذي عليه أهل العلم أن السّر لا يباح به إذا كـان على صـاحبه

$$
\text { منه مضرة" (r) (1) }
$$

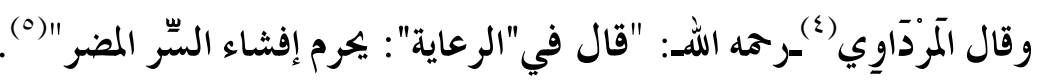

ولعل هذا يتو افق مع ما تقوم به أغلب الجهات الصحية من ذكر التشخيص المرضي صـر احةً إذا

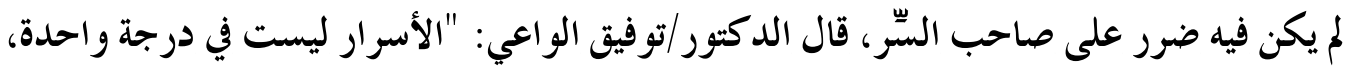

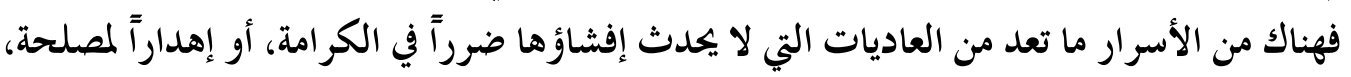

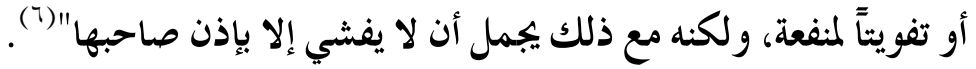

\section{ويمكن الاستدلال لهذا القول بما يأتي (V):}

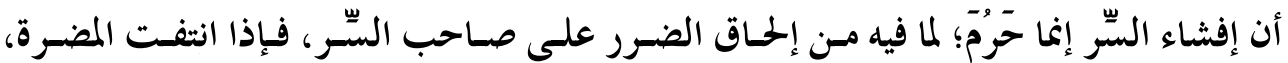

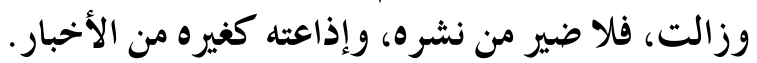

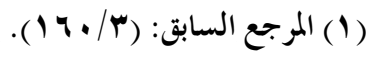

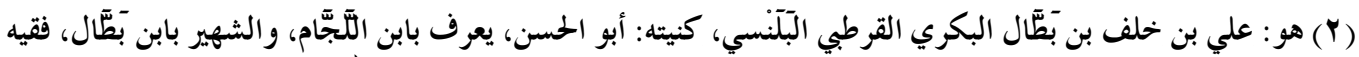

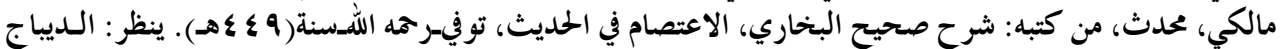

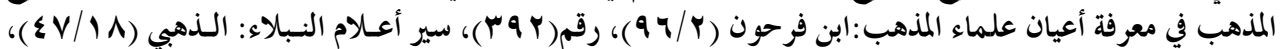

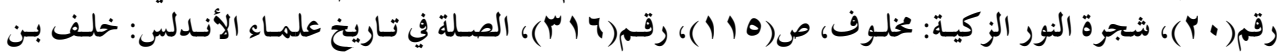

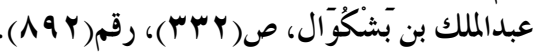

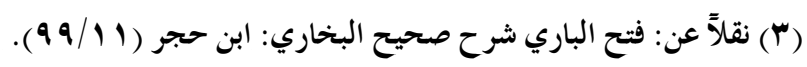

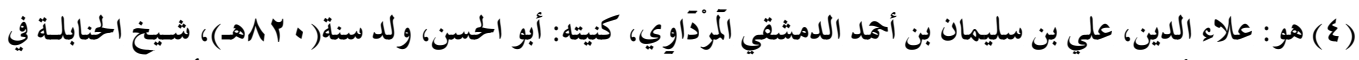

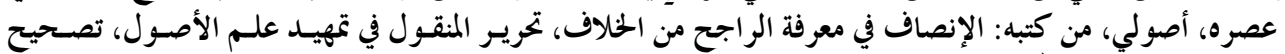

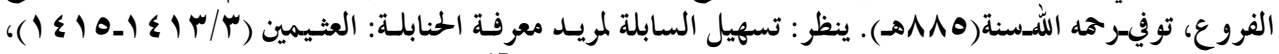

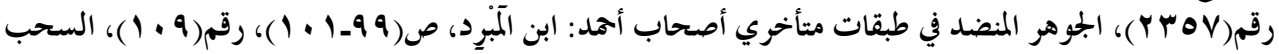

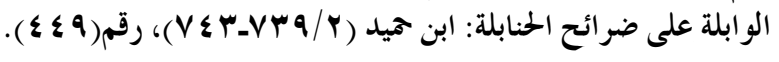

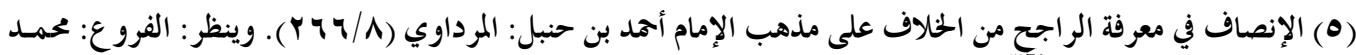

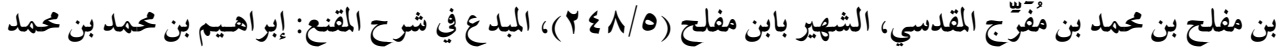

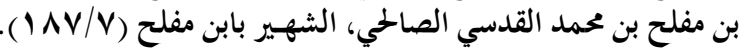

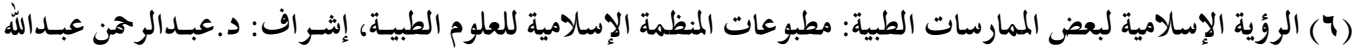

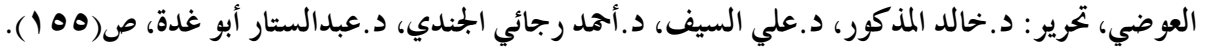
(V) حاولت استنباط الاستدلال لهم، ولم أجده صر احة. 
ويمكن مناقشة ذلك:

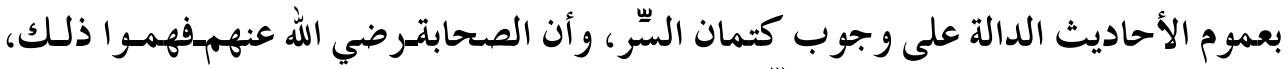

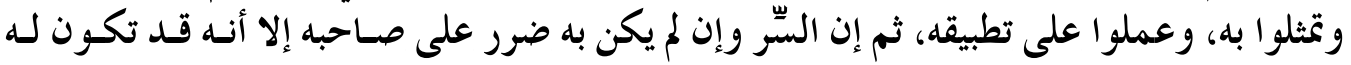

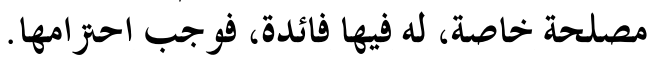

القول الثالث: إباحة إفشاء السِّ إذا مات صاحبه، ولمه ولم تلحقه بسبب الإفشاء مضرة. وقال به بعض أهل العلم، وصفهم ابن بََّّال-رحه اللهـبالأكثرين، فقـال : "وأكثرهم يقـول: إنـه.

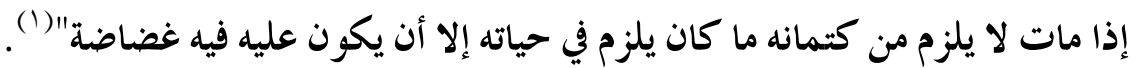
وبوب البخاري ــ رحه الله ـ في صحيحه، فقال: "باب: من ناجى بين يدي الناس، ولم يخبر بسـر

$$
\text { صاحبه فإذا مات أخبر به"(r). }
$$

وذهب ابن حجر- رحه الله ـ إلى التفصيل في هذه المسألة، فقال: "الذي يظهر انقسام ذلك بعـــ

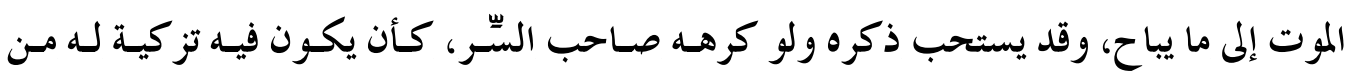

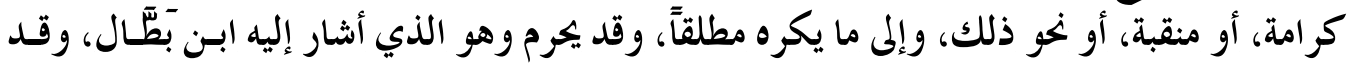

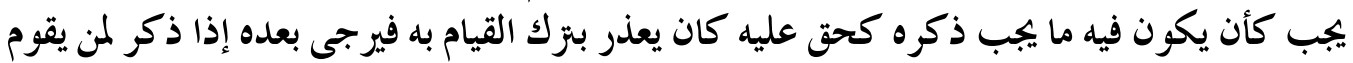

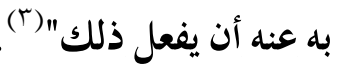
ويمكن الاستدلال لهذا القول:

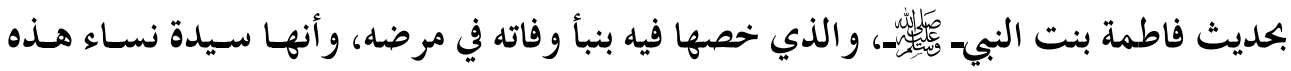

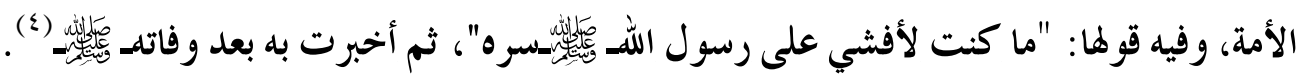

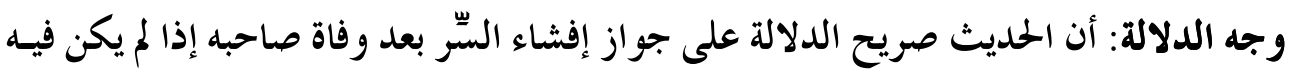
مضرة عليه.

$$
\text { * القَسم الثاني: الأسرار الخحرة. }
$$

من الأسرار ما يحرم على صاحبه الإقدام على فعله نحو إذا أسر المرء إلى آخر بأنسه سـيقتل فلاناً، أو أنه سوف يرتكب جريمة الزنا.

$$
\begin{aligned}
& \text { (1) نقلاً عن: فتح الباري شرح صحيح البخاري: ابن حجر (11/99/9). }
\end{aligned}
$$

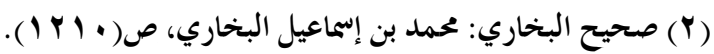

$$
\begin{aligned}
& \text { (r) فتح الباري شرح صحيح البخاري: ابن حجر (11/19 9 9). }
\end{aligned}
$$


و قرر العلماء-رحهم اللهـ بأن الأصل في السِّر الكتمان، قال ابـن حجرـرحمه الله: "الأصـل في

السِّر الكتمان، و وإلا فما فائدته ؟!" (1) .

وجاء في قرار مجمع الفقه الإسلامي، المنبثق من منظمة المؤتمر الإسـلامي بشـأن" السِّر في المهـن

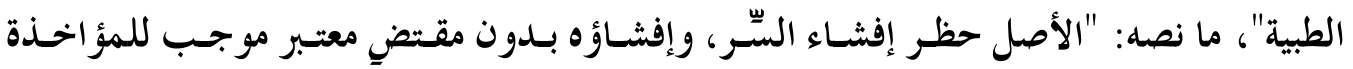

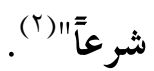

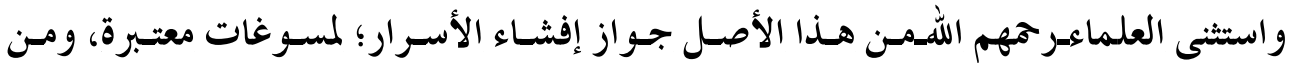
نصوص العلماء في هذا الشأن ما يأتي:

أ_قال الغزالي-رحه اللهـ: "وبالجملة، فليسكت عن كل كلام يكرهه بحلة وتفصيلاً إلا إذا وجب

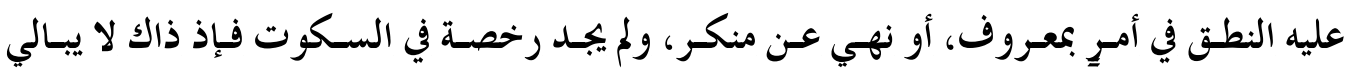

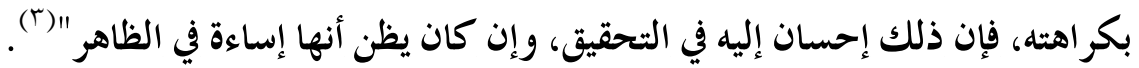
بـقرر النووي-رحه اللهعند حديثه عن النميمة أن الأصل فيهـا التحريم، ولكـن يسـتثنى مـن

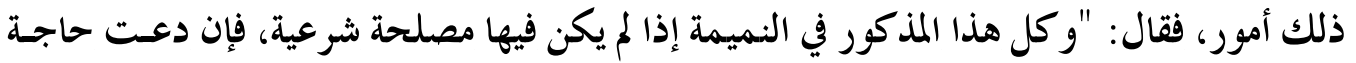

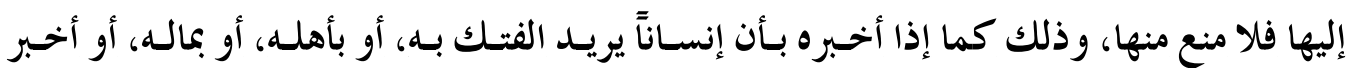

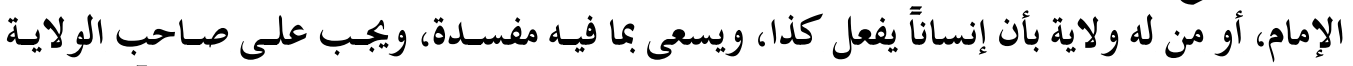

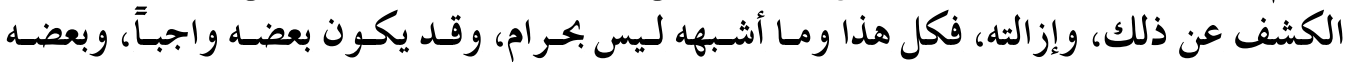

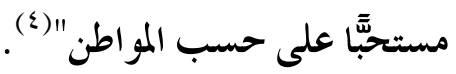
جـ قال ابن رجب (ْ) - رحه اللهـعند حديثه عن الغيبة: "اعلم أن ذكر الإنسان بما يكره إنما يكون

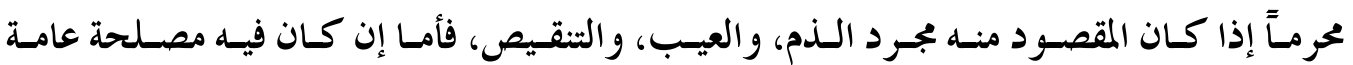

(1) فتح الباري شرح صحيح البخاري: ابن حجر (1//99).

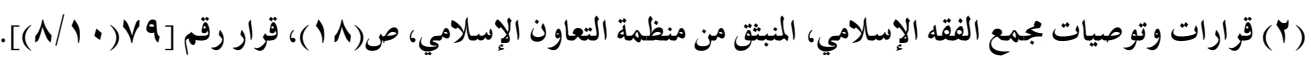

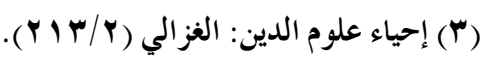

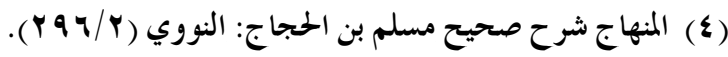

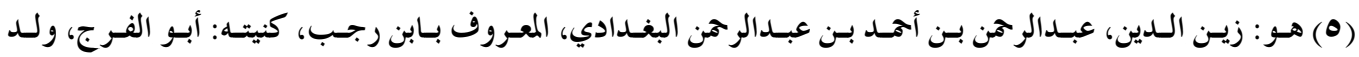

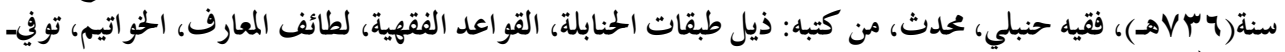

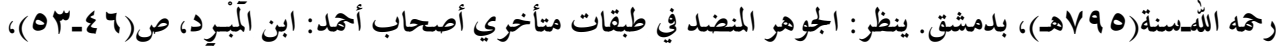

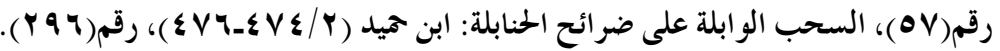




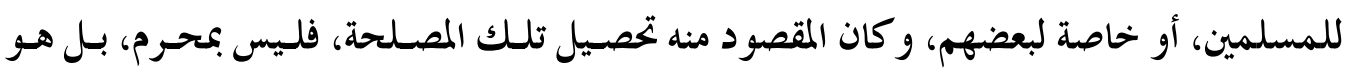

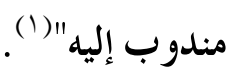

حـقال القرافي (r)-رحمه الله ـ عند الححديث عن النميمة: "ويستثنى منها أن فلاناً يقصـد قتلـك في

موضع كذا، أو يأخذ مالك في وقت كذا، ونحو ذلك؛ لأنه من النصيحة الواجبة"(ب).

هـ ـ قال النفراوي (๕) ـ رحه اللهـعند الحديث عن النميمة: "وينبغي للإنسان أن يسكت عن كـل

ما يراه من أحو ال الناس إلا ما كان في حكايته مصلحة مسلم، أو دفع معصية" (0).

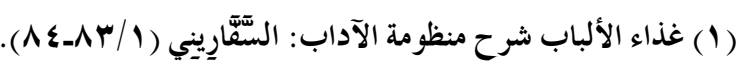

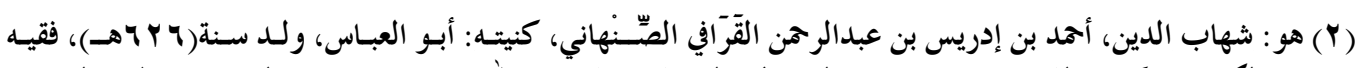

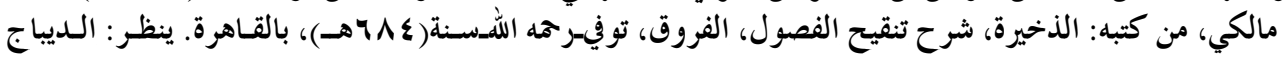

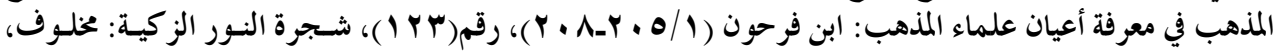

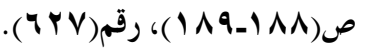

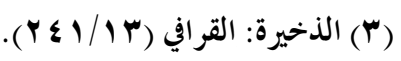

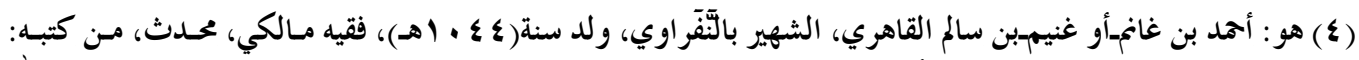

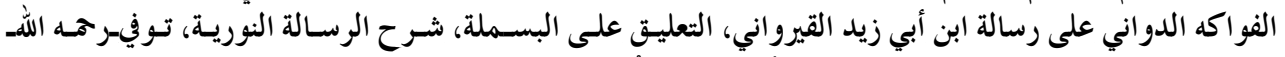

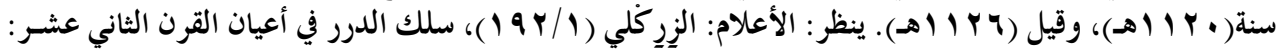

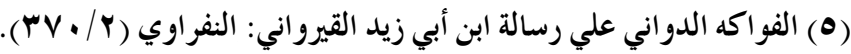

$$
\begin{aligned}
& \text { - ^ᄉ乏 - }
\end{aligned}
$$




$$
\text { ويكن الاستدلال على ذلك، بما يأتي: }
$$

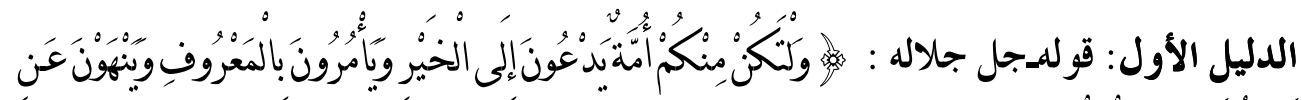

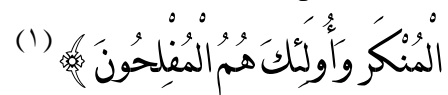

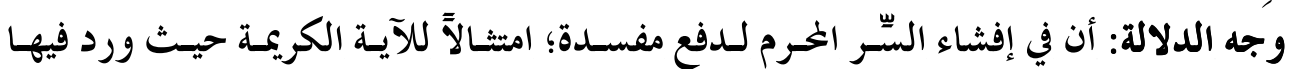

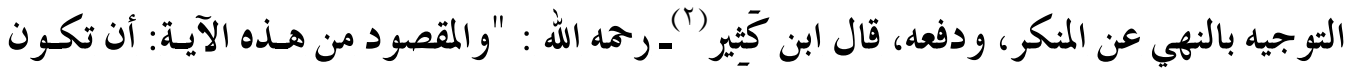

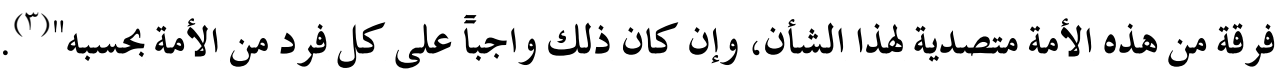

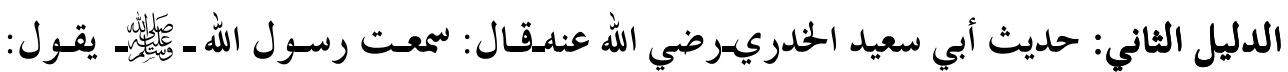

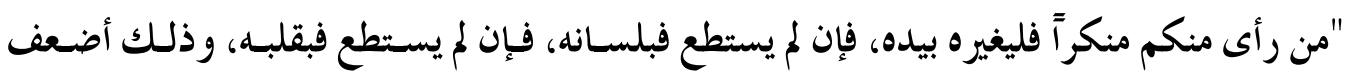

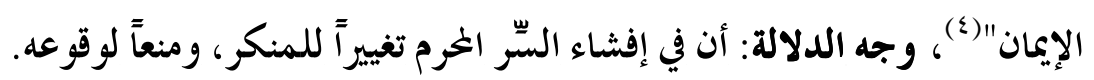

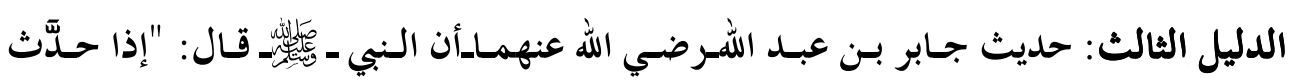

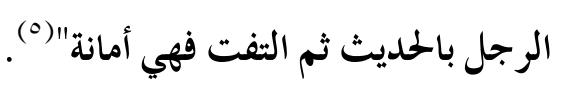

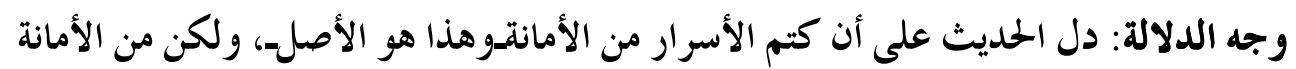

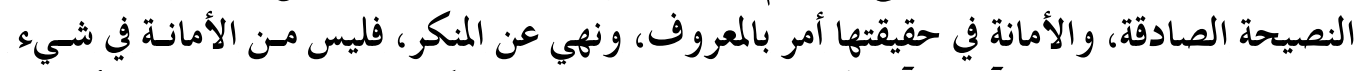

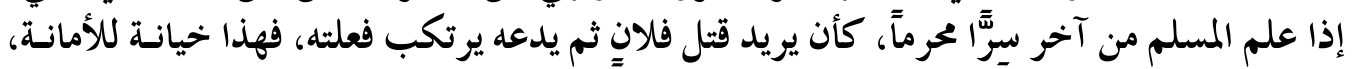

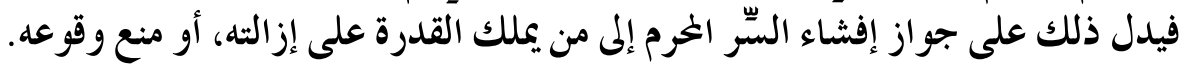

(1) (1) سورة آل عمر ان، الآية (؟ • (1).

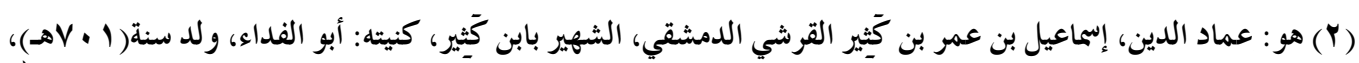

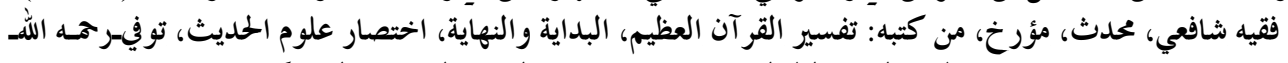

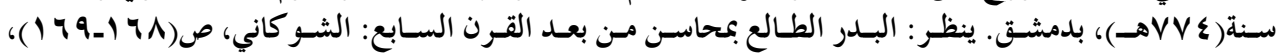

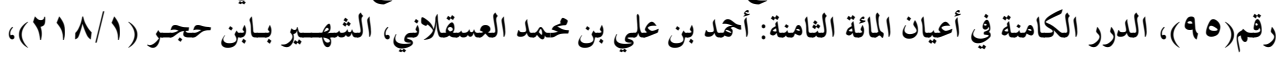

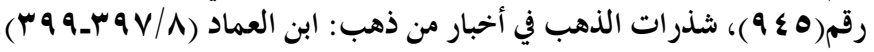

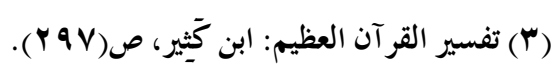

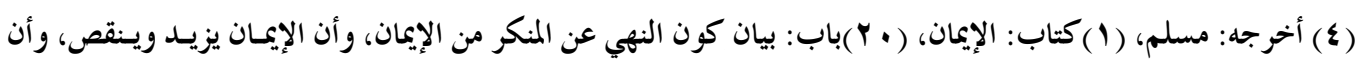

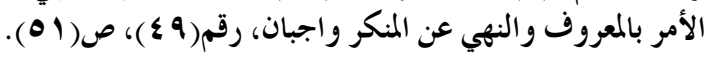

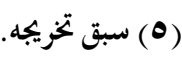




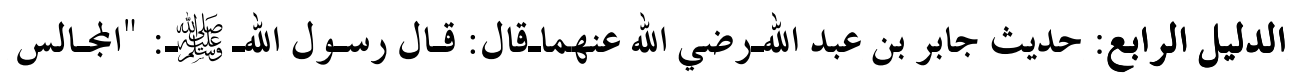

بالأمانة إلا ثلاثة مجالس: سفك دم حرام، أو فرج حرام، أو اقنطاع مال بغير حق" (1). وجه الدلالة: أن الححديث صريح الدلالة على أن الأسرار الخرمة يجوز كشف الستار عنها؛ لمنع وقوعها، أو إزالتها.

ويمكن مناقشة ذلك: بأن الحديث ضعيف لا يقوى على الاحتجاج به.

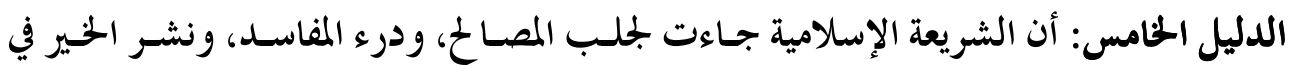

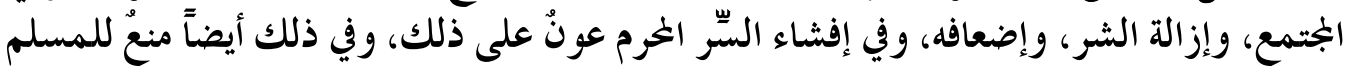
من الإقدام على فعل المنكرات. 


$$
\begin{aligned}
& \text { الفصل الثالث } \\
& \text { إفشاء السّر الطي الطي } \\
& \text { المبحث الأول } \\
& \text { أركـان جريسمة إفـشاء السِّر الطبي. } \\
& \text { جريمة إفشاء السّرّ الطبي تقوم على أربعة أركان هي (1) : } \\
& \text { الركن الأول: أن يكون ما تم إفشاؤه سِرَّا. } \\
& \text { الركن الثاني: فعل الإفشاء"الركن المادي". }
\end{aligned}
$$

الركن الثالث: أن يكون فعل الإفشاء صادراً من الطبيب، ونحوه"صفة الجاني". الركن الرابع: أن يصدر فعل الإفشاء بقصد جنائي"الك كن المعنوي". وتفصيل ذلك كما يأتي:

\section{* الركن الأول: أن يكون ما تم إفشاؤه سِرَّا.}

يشتّزّ فيَّ جريمة إفشاء سر المهنة الطبية أن يكتسب السِّر الذي وقع عليه فعل الإفشاء؛ وصـف كونه سِرَّا طبيَّاً.

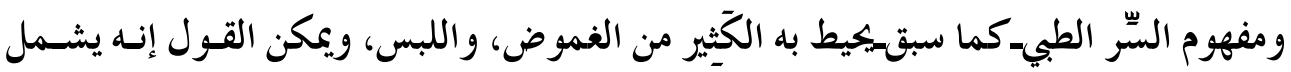

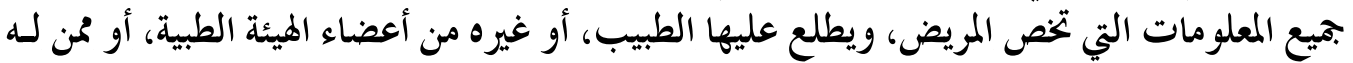

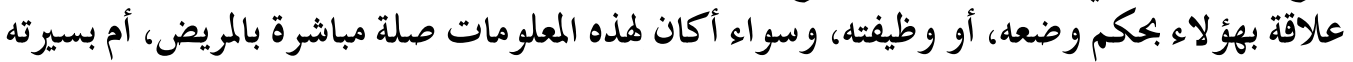

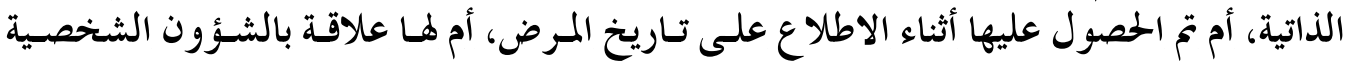

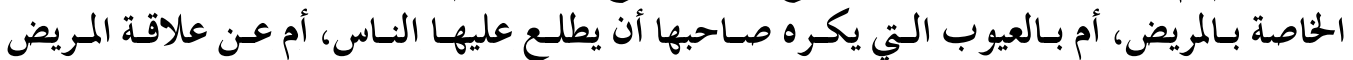

وحتى تكتسب الو اقعة صفة السِّ الطبي لا بد من أن تكون لها صلة بمهنة الطب (r).

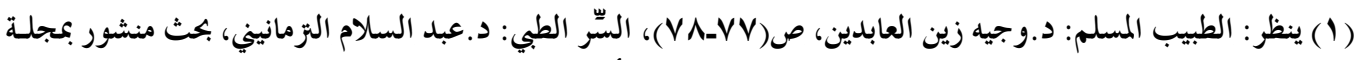

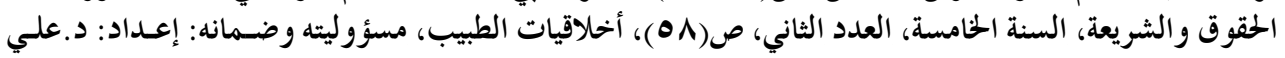

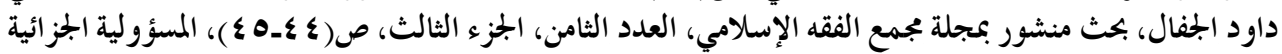

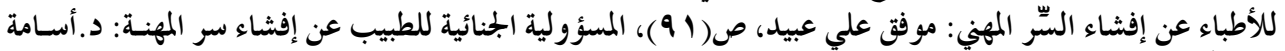

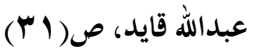

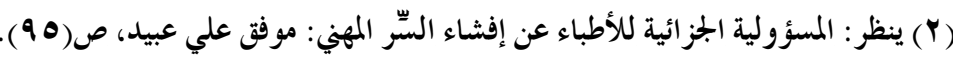

$$
\begin{aligned}
& \text { - ANV - }
\end{aligned}
$$




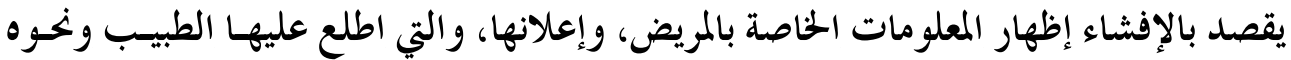

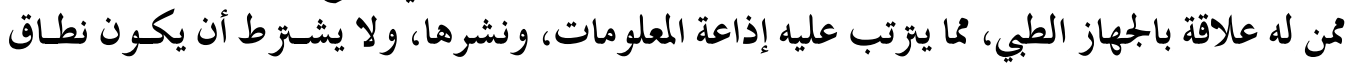

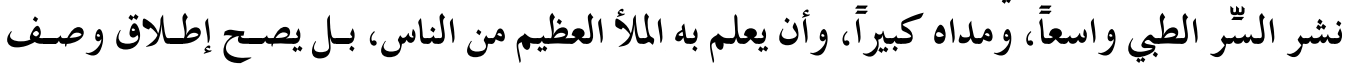

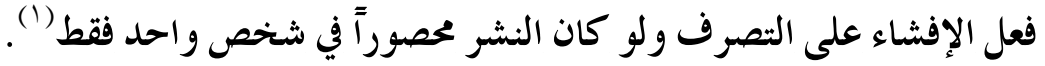
ولا يشتز ط ذكر اسم صاحب السِّر، و إنما يكتفى بكشف بعض معـالم شخصسيته التي يمكن مـن

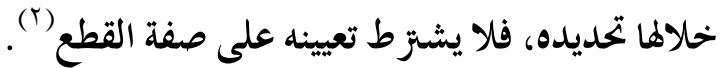

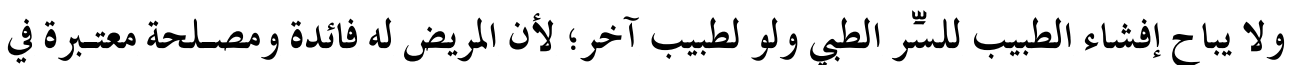

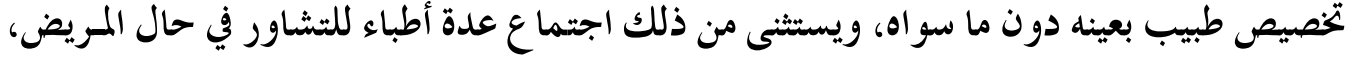
للوصول إلى تشخيص دقيق للمرض، وعليهم جميعاً تقع مهمة كتمان السِّ (َ).

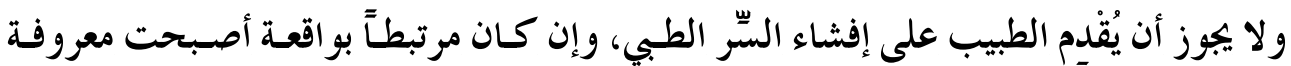

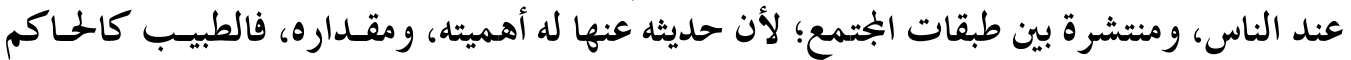
في المسألة (๕) . ويتحقق فعل الإفشاء بأية طريقة كانت كالتصريح بالقول، أو الكتابة، أو بالإشارة، أو بالإيماء.

ومن أهم وسائل إفشاء سر المهنة الطبية، ما يأتي (0): أ. النشر في الصحف، والدوريات العلمية.

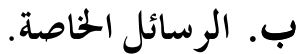

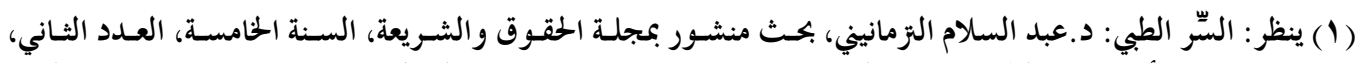

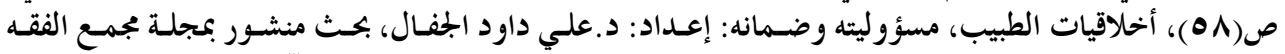

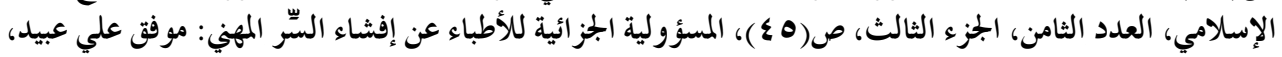

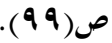

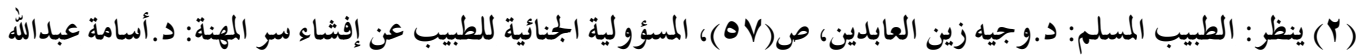

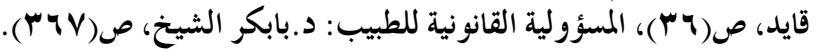

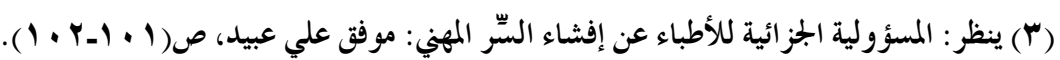

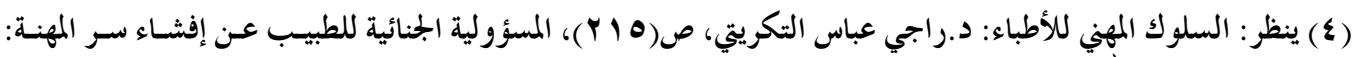

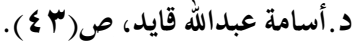

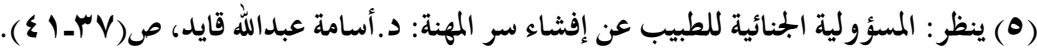




$$
\text { د. التقارير، والمشافهة في المؤتمرات العلمية الطبية. }
$$

ومن صور الإفشـاء أن يـذكر أسمـاء المرضسى في الكتـب، والمقـالات العلميـة الطبيـة، أو نشـر

* الر كن الثالث: أن يكون فعل الإفشاء صادراً من الطبيب ونحوه "صفة الجاني".

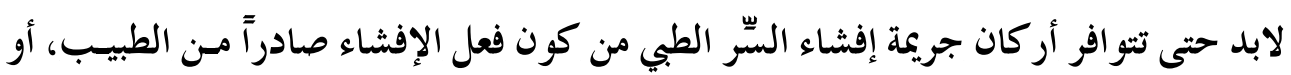

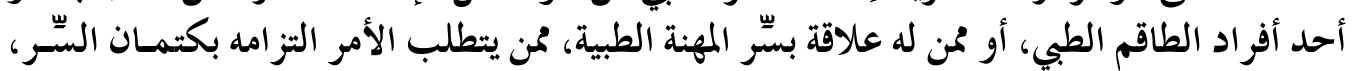

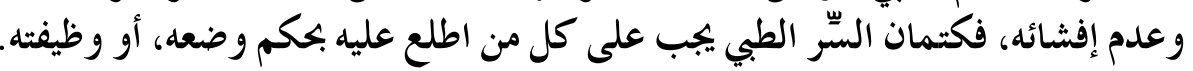

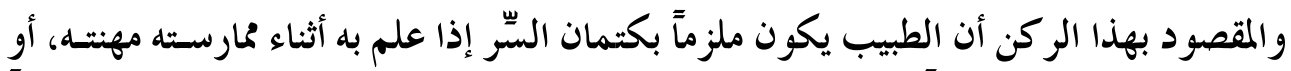

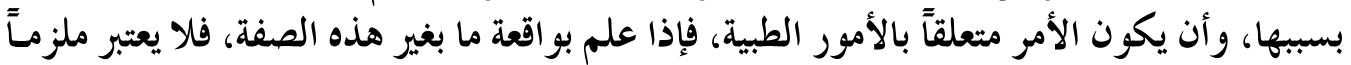

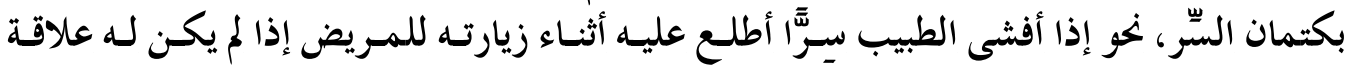

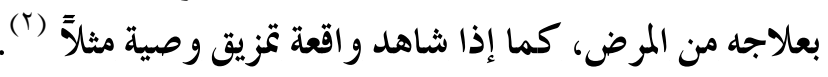

\section{وبهذا نلحظ أنه يشترط في هذا الركن أمران(َ) :}

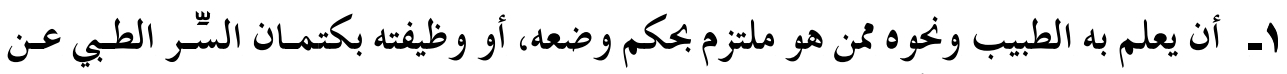
طريق ممارسته لعمله، أو بسببها.

$$
\text { r. - أن يكون السِّر متعلقاً بالأمور الطبية. }
$$

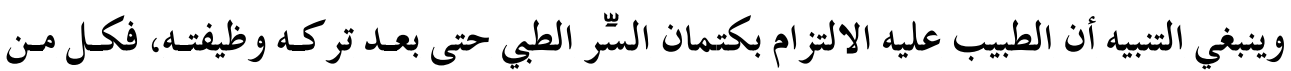

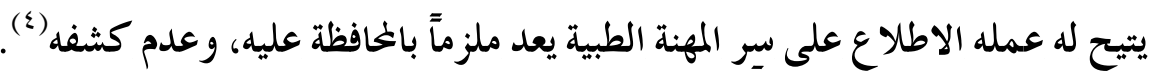

(1) ينظر : السّر الطبي: د.عبد السلام التزمانيني، بحثث منشسور بمجلـة الحقوق و الشـريعة، السـنة الخامسـة، العـدد الثـاني،

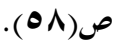

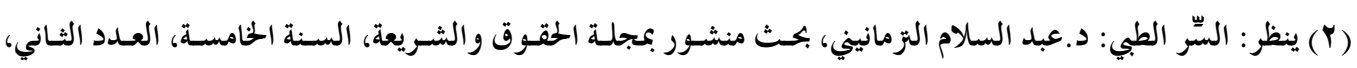
ص(09).

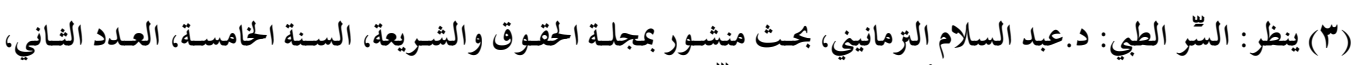

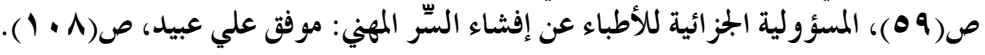

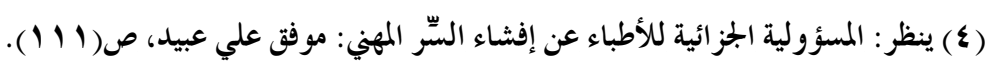

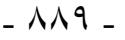




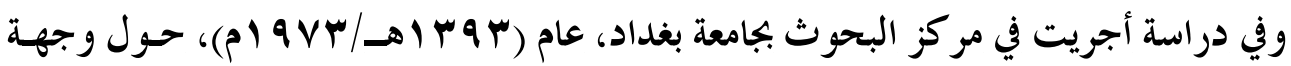

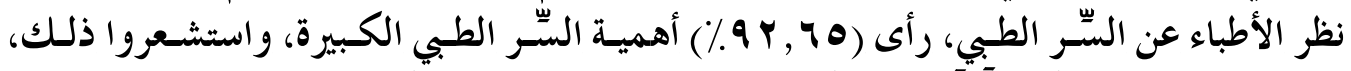

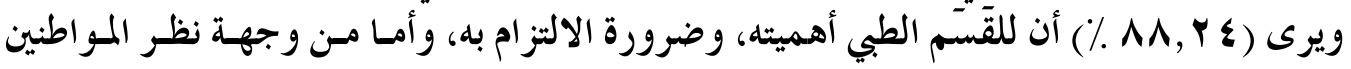

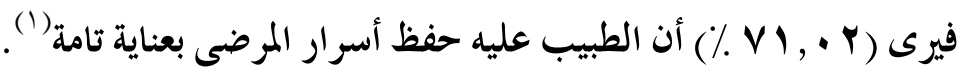

* الر كن الرابع: أن يصدر فعل الإفشاء بقصد جنائي "الر كن المعنوي".

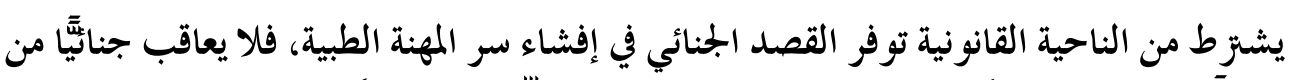

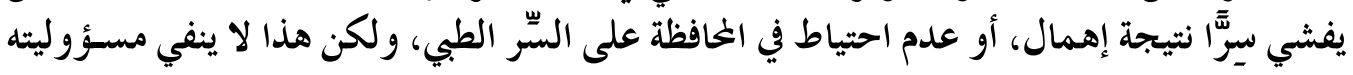

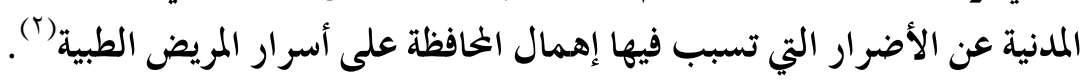
ولا عبرة بالبواعث، فِافشـاء السِّ الطبي لا يباح، ولو كان القصسد منسه درء مسـؤولية أدبيسة، أو

\section{وفي الشريعة الإسلامية تنقسم الجر ائم باعتبار قصد الجاني إلى قسمين( ):}

$$
\text { *قلِسم الأول: الجحر ائم المقصودة. }
$$

و وهي: التي يتعمد الجاني فيها إتيان الفعل الخرم، وهو يعلم بحرمة الفعل، ومن هذا تعمُّد الطبيـب

"القِسم الثاني: الجر ائم غير المقصودة.

وهي: التي لا ينوي فيها الجاني إتيان الفعل الغرم، ولكن يقع الفعل نتيجة خطأ.

والحطأ على نوعين() :

$$
\text { (1) ينظر: العلاقة بين الطبيب والمريض في الممارسة العامة للطب في العراق: علي ولفته، ص(Y ץ ( ). }
$$

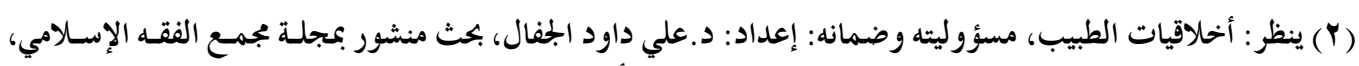

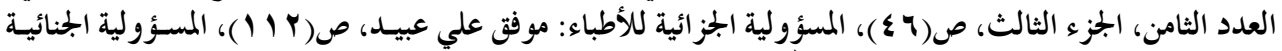

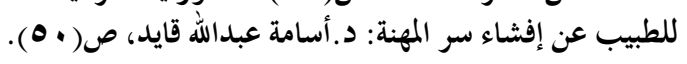

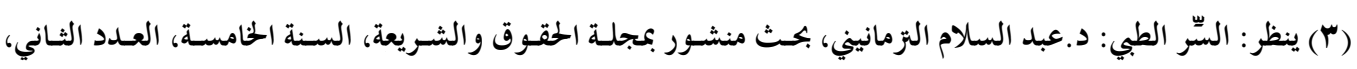

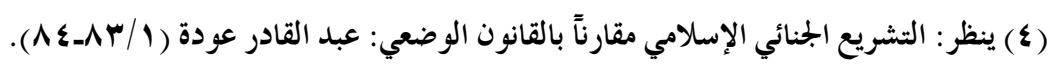

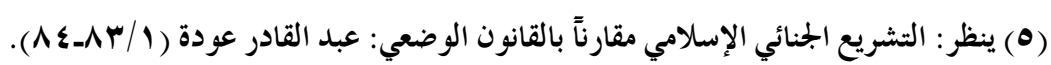


النوع الأول: أن يكون الفعل مقصوداً، والجريمة غير مقصسودة، وهـو أن يقصـد الجـاني الفعـل

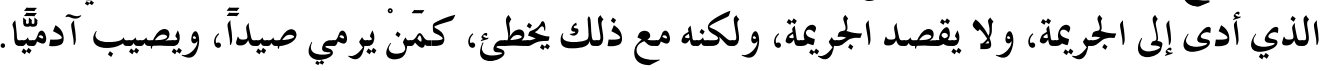

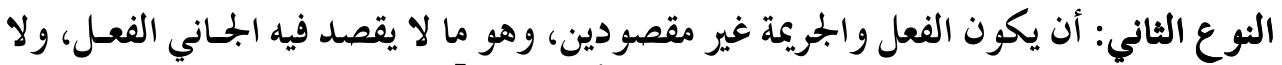

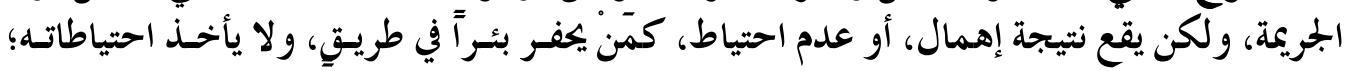

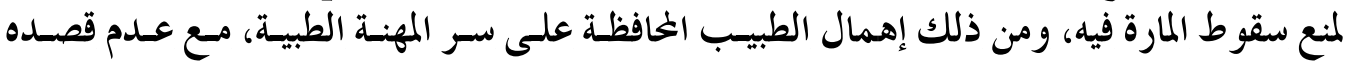
الإفشاء. 
المبحث الثاني

إفشاء الطبيب للسر الطبي

* مدخل:

يعتبر الطبيب مرتكز المهنة، وعليه مدار نجاحها، فهو أقـوى عوامـل تطورهـا، ورقيهـا في سـلم الإبداع العلمي، وبله تسمو في أداء رسالتها الخالدة.

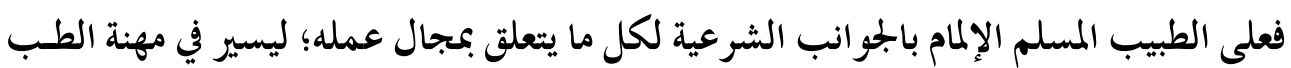

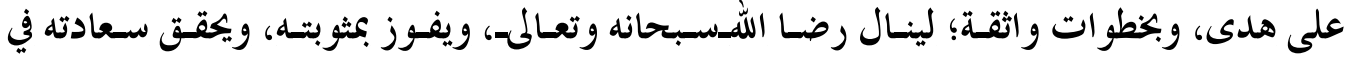

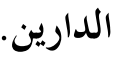

$$
\begin{aligned}
& \text { المطلب الأول } \\
& \text { حكم إفشاء الطبيب للسّر الطبي. }
\end{aligned}
$$

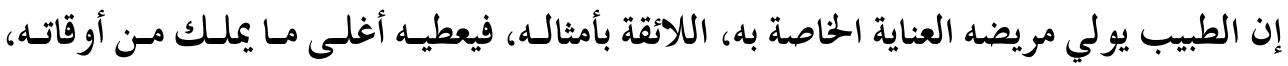

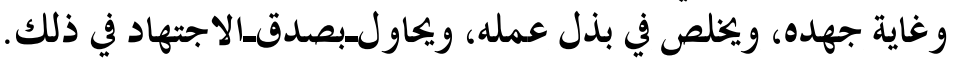

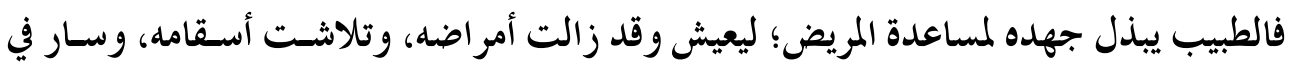

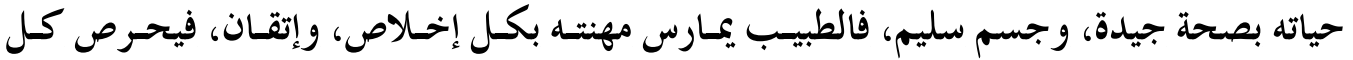

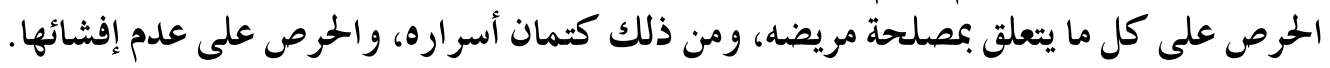
قال الدكثتور/علي الجففال: "إن إفشاء السِّر في حسد ذاتـه، جريمـة خُلقيـة قبـل أن تكـون جريمـة

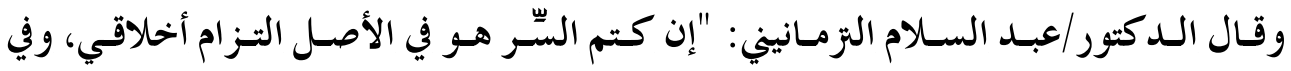

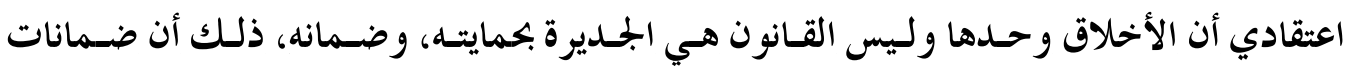

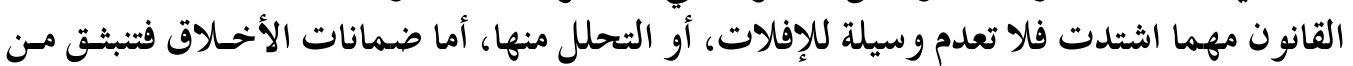

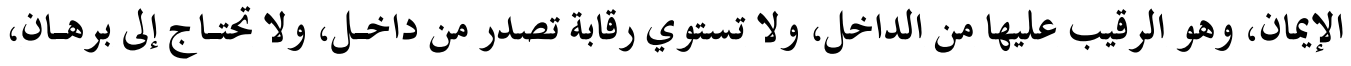

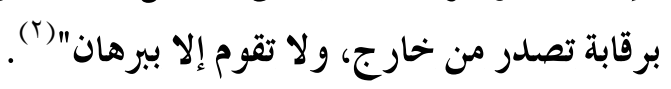

( ) أخلاقيات الطبيب، مسؤوليته وضمانه: إعداد: د.علي داود الجففال، بحث منشور بمجلة مجمـع الفقـه الإسـلامي، العـدد

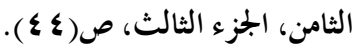

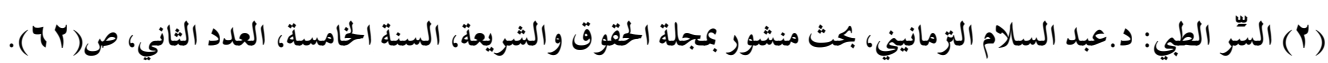
- N9r _ 


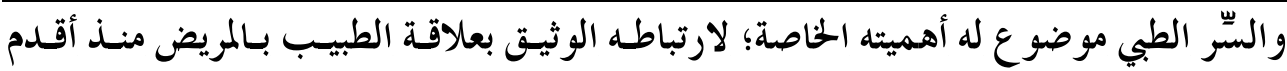

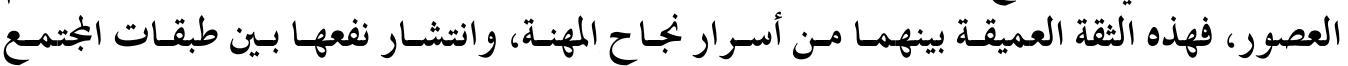

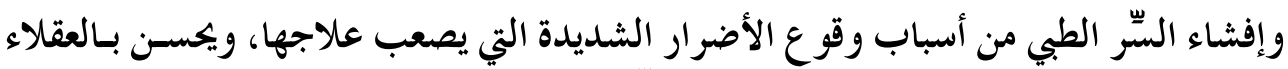

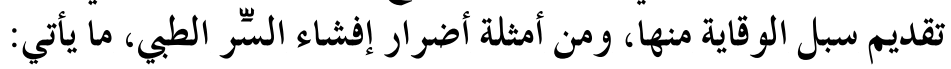

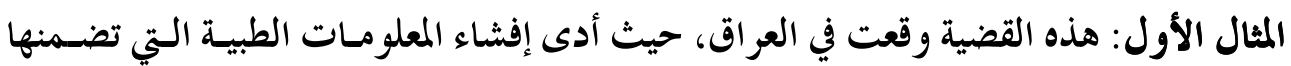

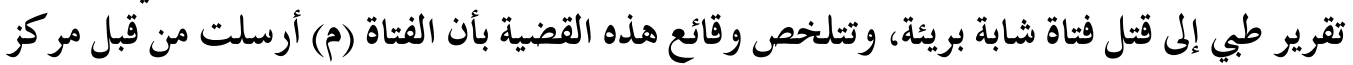

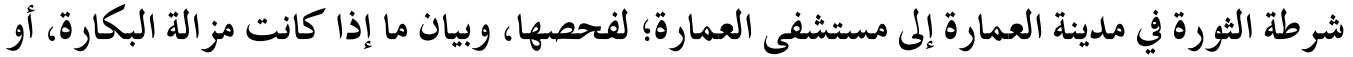

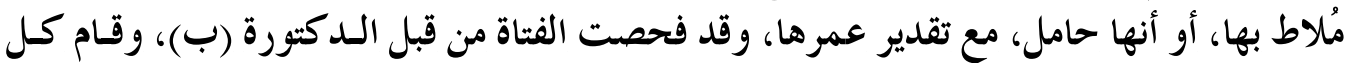

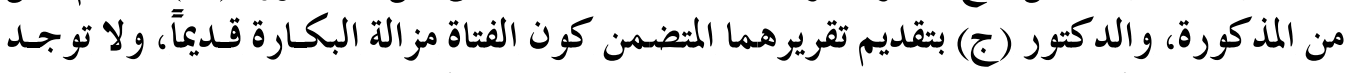

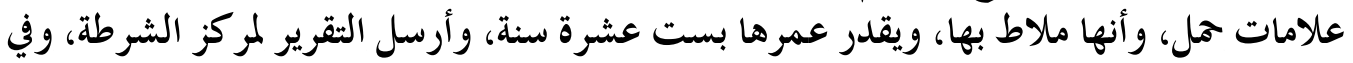

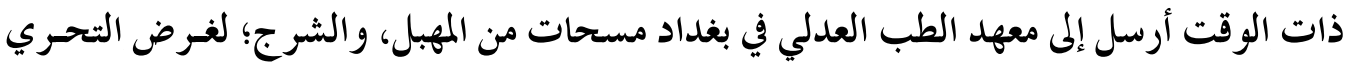

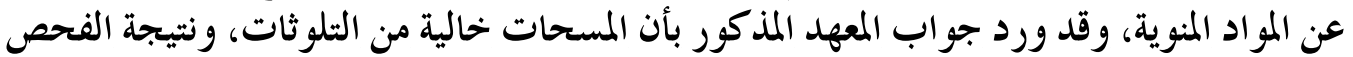
سالبة.

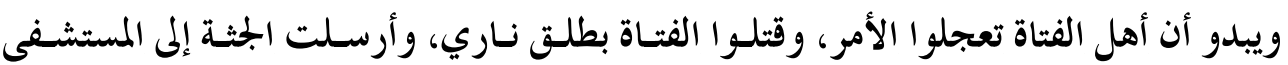

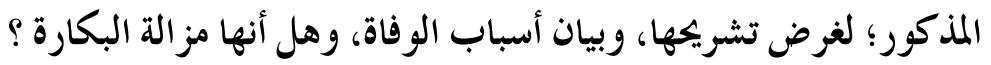
وعرضت الجثثة على لجنة من الأطباء الاختصاصيين في مستشفى العمارة من غير المـذكورين في التقرير الأول، ورجاءت نتيجة تقرير اللجنة بما يأتي:

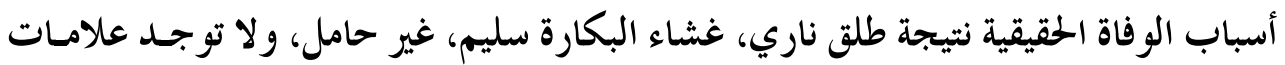

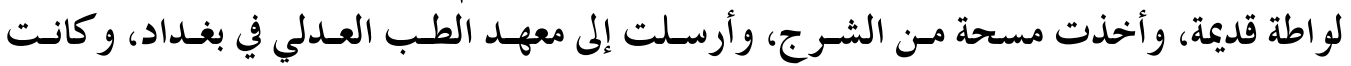
النتيجة سالبة.

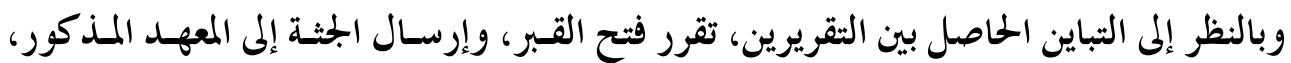

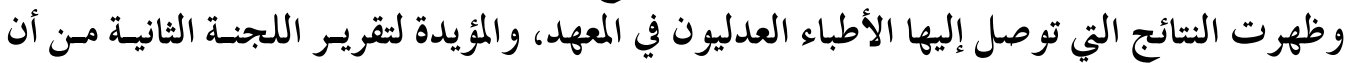

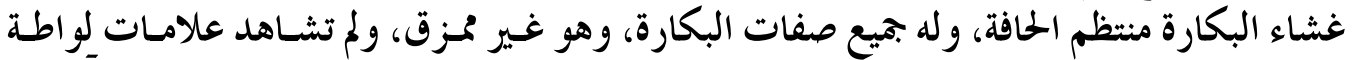
قديمة، أو حديثة.

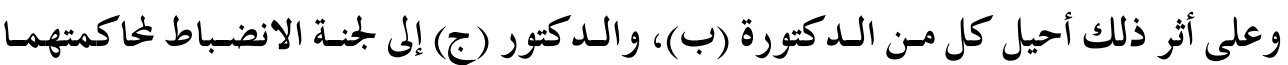

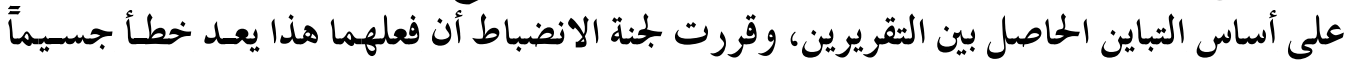

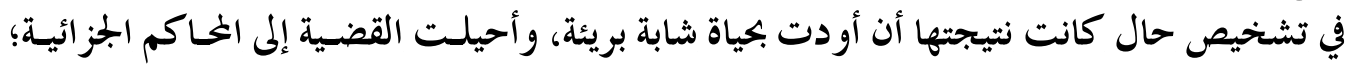
لإجر اء الخاكمة: (1)

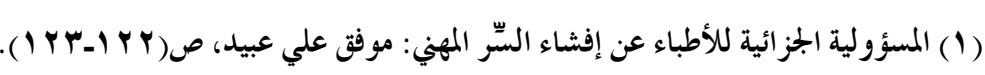


فتأمل في النتائج الوخيمة لإفشاء أسرار المرضى، وقبح آثارها على حياة الأبرياء !

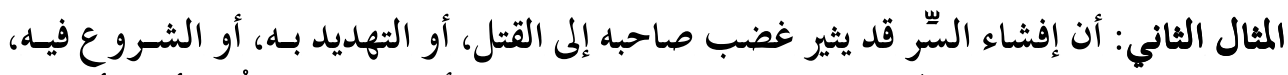

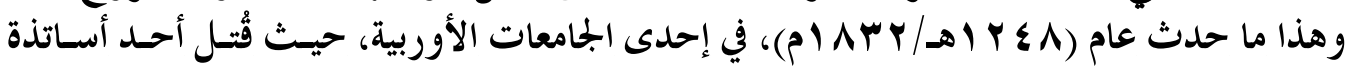

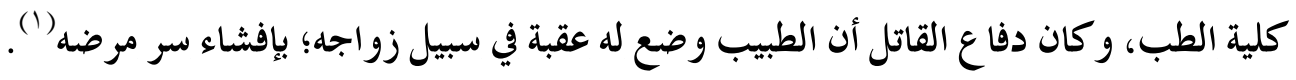

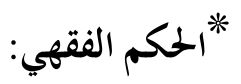

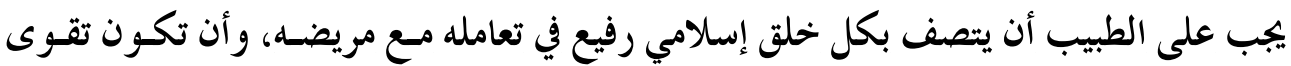
الله ـ سبحانه وتعالى ، و مر اقبته في السر والعلن هي الميز المي ان الفاصل في في تعامله مع الآخرين.

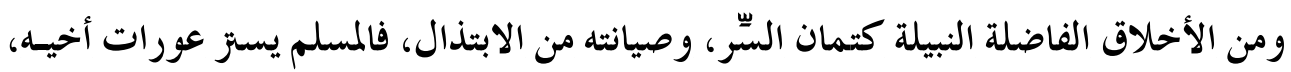

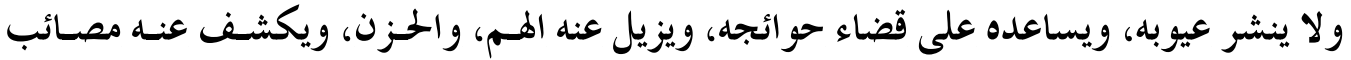
الدنيا، و وكروبها. فالأصل: وجوب كتمان السِّر، وتحريم إفشائه. قال ابن حجر-رحمه الله : "الأصل في السِّّ الكتمان، وإلا فما فائدته؟!" (r). وقال محمد مختار السلامي: "الأصل أن الطبيب لا يجوز لـه أن يطلـع أحسداً على مـا تهيـأت لـه.

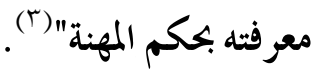

وجاء في"الضو ابط الإداريـة والإجر ائيسة للحفــاظ على عـورات المرضـى" الصـادرة مـن وزارة الصحة بالمملكة العربية السعودية: "على الفريق الطبي المعالج مناقشـة الحسال الطبيـة للمـريض، مـع الخحافظة على خصو صية المرضى، وسرية المعلومات" (؟).

(1) ينظر : أخلاقيات الطبيب، مسؤوليته وضمانه: إعداد: د.علي داود الجفال، بحث منشور بمجلـة مجمـع الفقـه الإسـلامي، العدد الثامن، الجزء الثالث، ص( ع ع ؟).

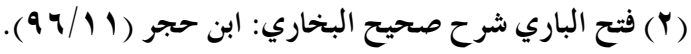

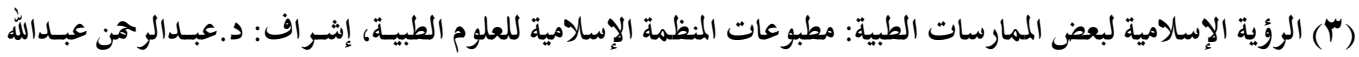

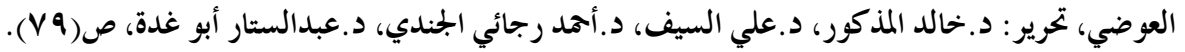

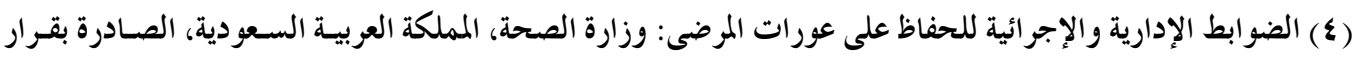

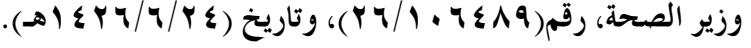


وجاء في قرار مجمع الفقه الإسلامي، المنبثق من منظمة المؤتمر الإسـلامي، بشـأن"السِّر في المهـن

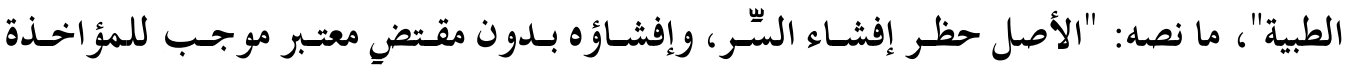

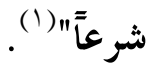

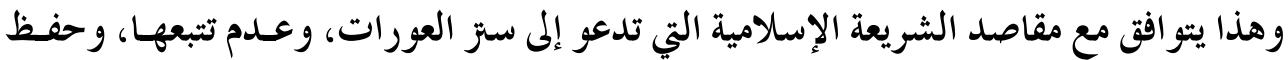
الأمانة، وصيانة العهد، والوفاء معاهد بالمو الثريعة الإليق.

\section{ولابد من التنبيه على أمور مهمة:}

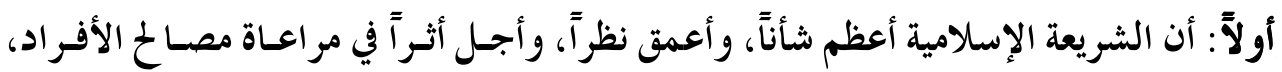

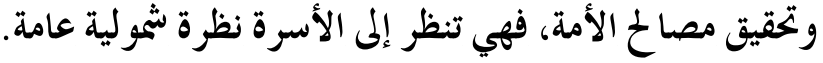

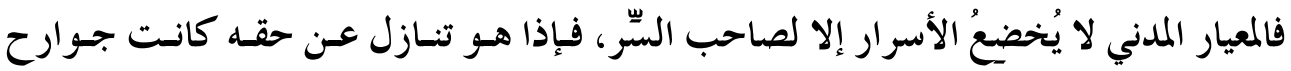

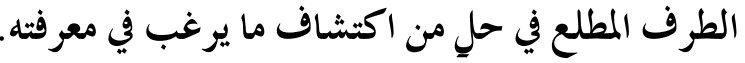

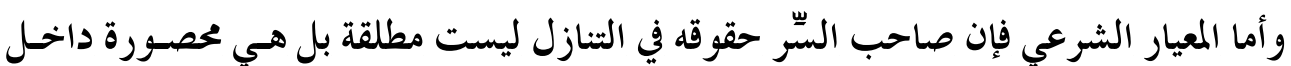

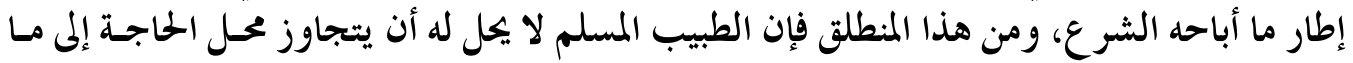

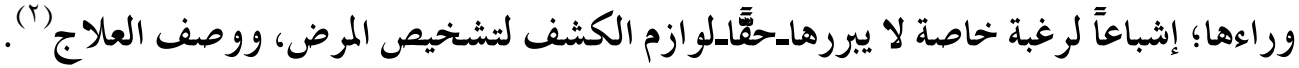

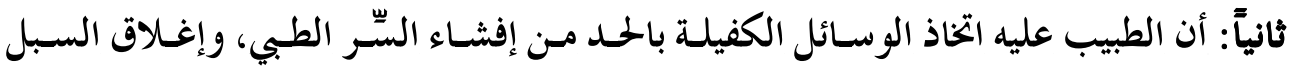

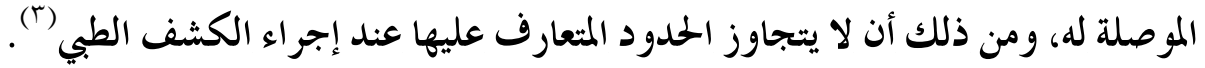

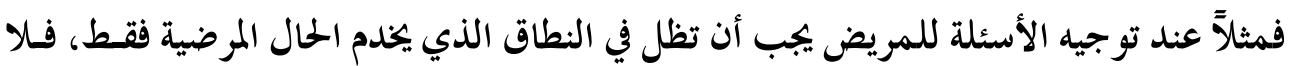

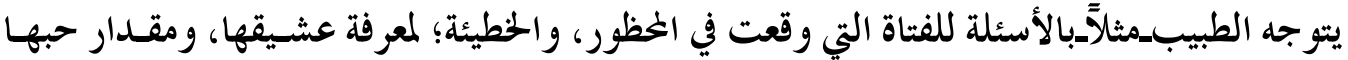

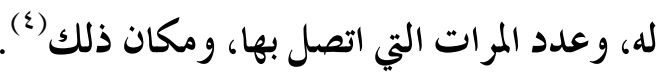

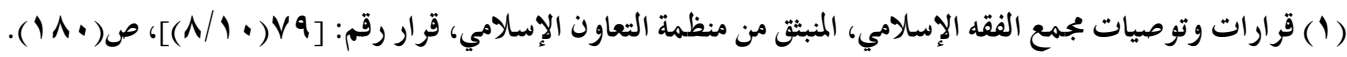

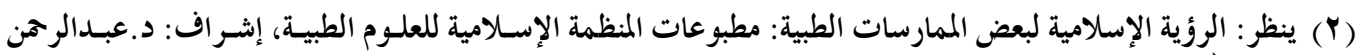

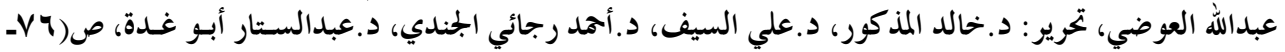

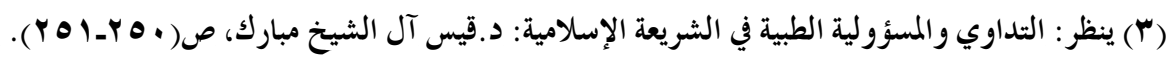

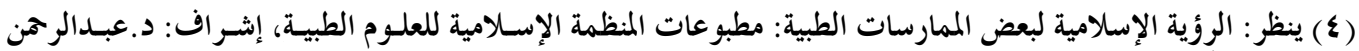

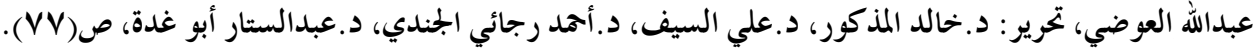




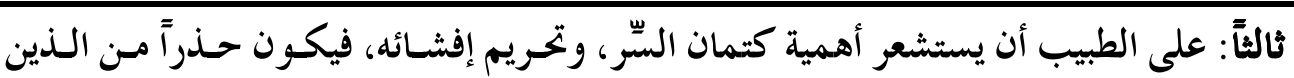

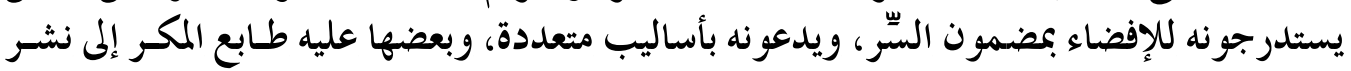

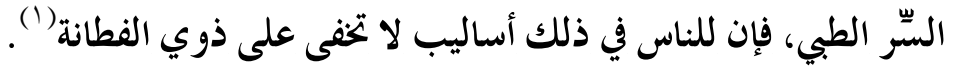

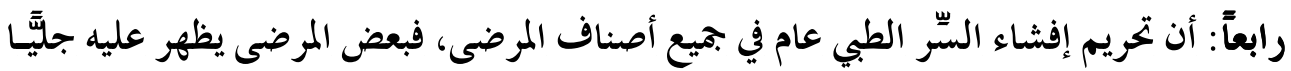

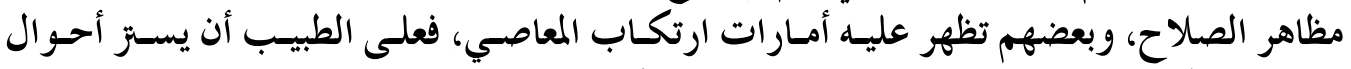

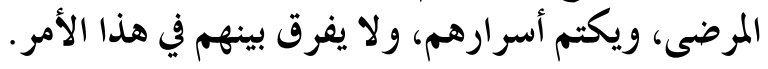

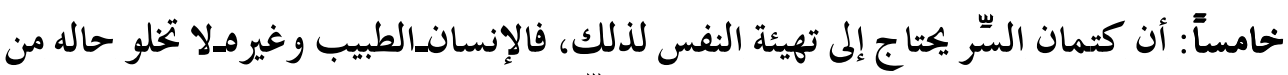

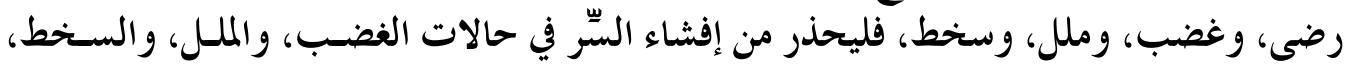

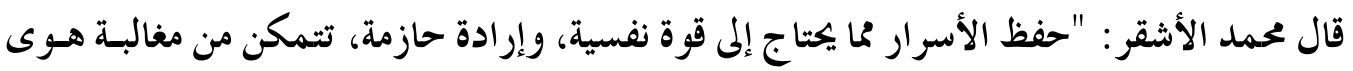

النفس، والتغلب عليه، و كان الإفشاء في الغالب ناشئاً عن قلة الصبر في هذه المعر كة النفسية"(؟). سادساً: يظن البعض أن السِّر الجحدير بالحفظ، والصيانة، وتحريم الإفشاء؛ إنما يقتصـر الأمسر فيسه

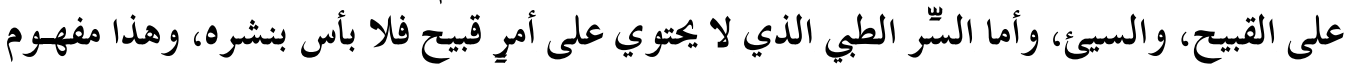
خاطئ-و إن شاع_فحفظ السّر الطبي عام، ومطلق، لا يتقيد بنوع ع معين (r) .

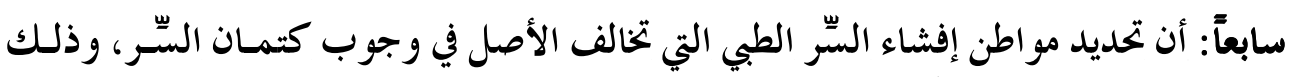

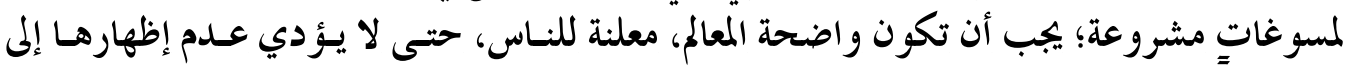

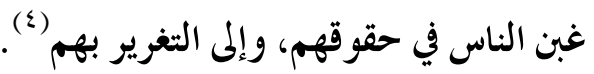

جاء في قرار مجمع الفقه الإسلامي، المنبثق من منظمة التعاون الإسلامي، بشـأن"السّـــــ في المهـن الطبية"، ما نصه: "الاستثناءات بشأن مو اطن وجسوب الإفشـاء، أو جـوازه، ينبغي أن يــص عليهـا

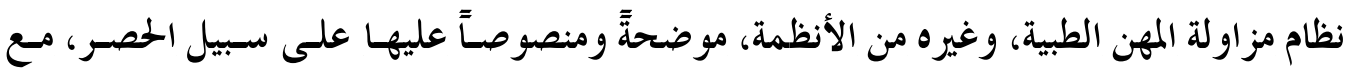

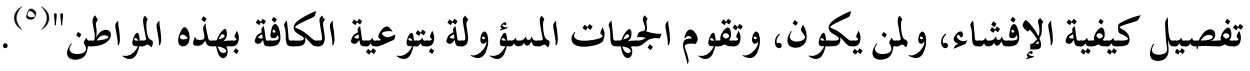

(1) ينظر: أبحاث اجتهادية في الفقه الطبي: د.محمد الأشقر، ص(00).

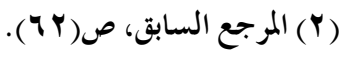

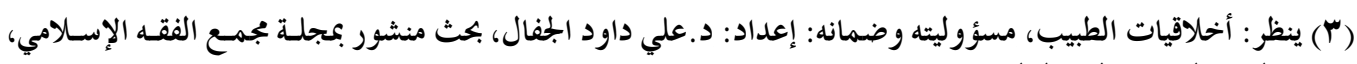

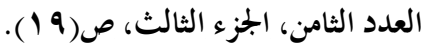

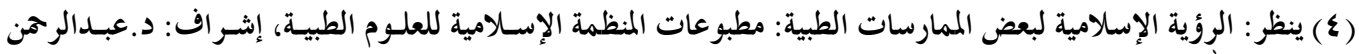

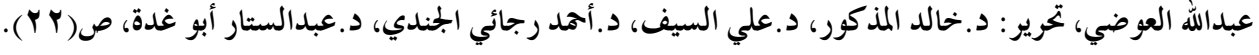

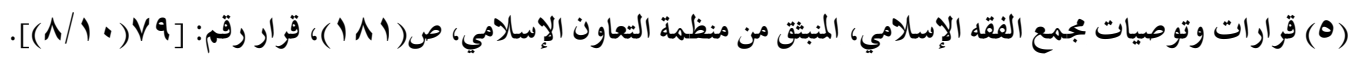




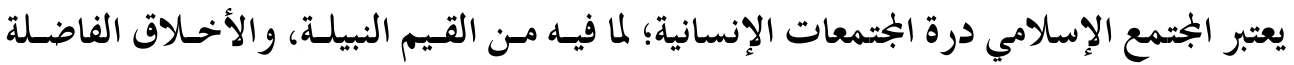

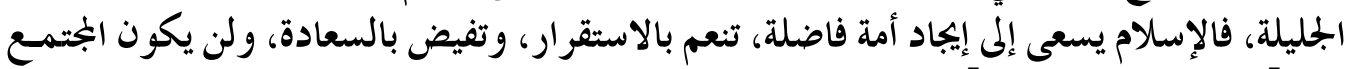

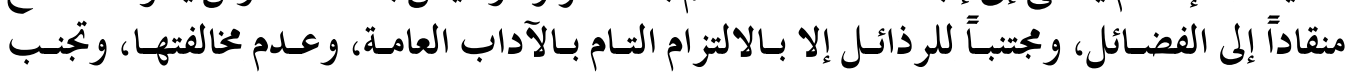

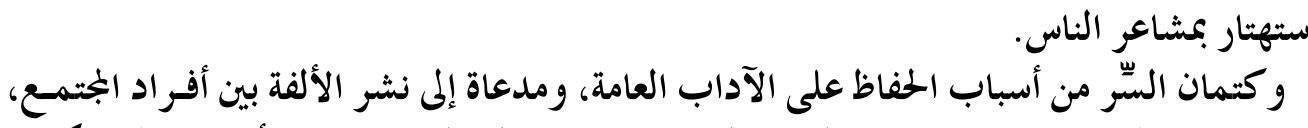

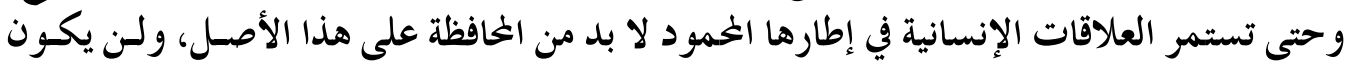

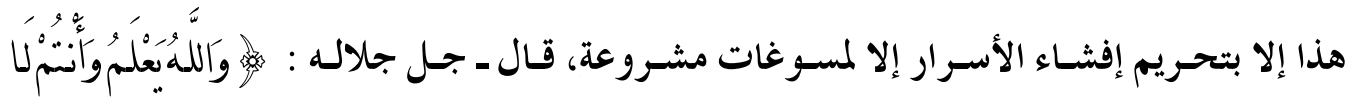

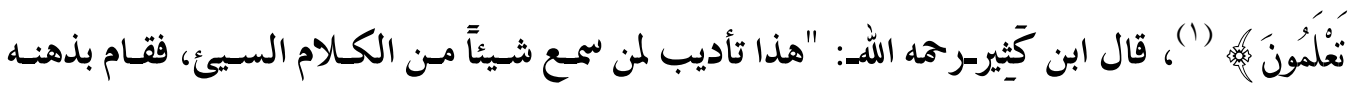

$$
\text { شيء منه، وتكلم به، فلا يكثر منه، ولا يشيعه، ويذيعه" (r). }
$$

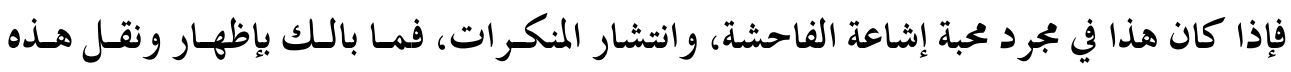
الأخبار !! وإفشاء أسرار المرضى القبيحة من هذا الباب.

\section{الأصل الثاني: وجوب ستز عورات المسلمين.}

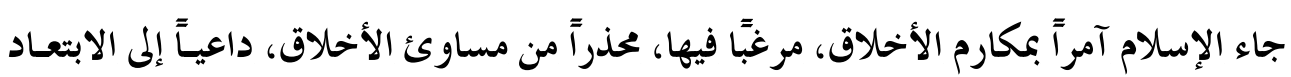

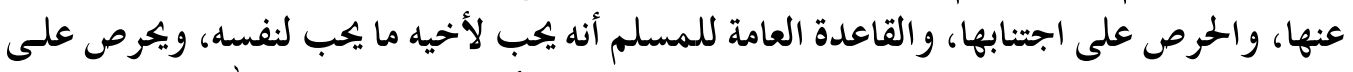

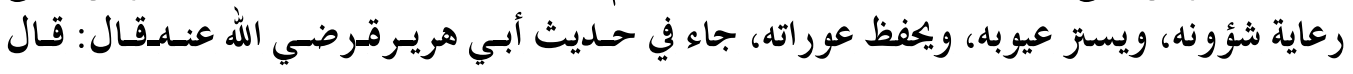

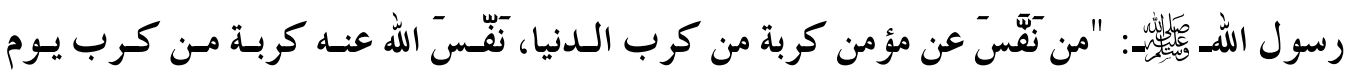

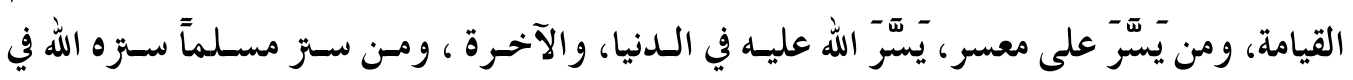

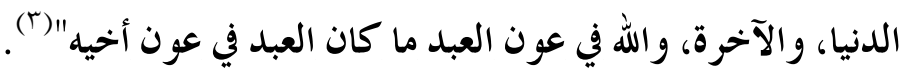

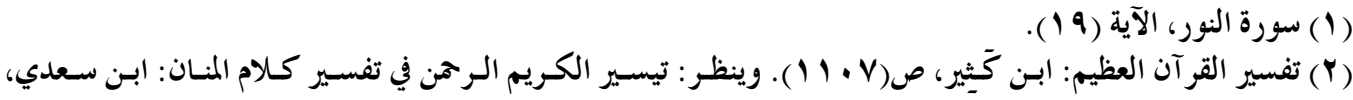

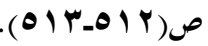

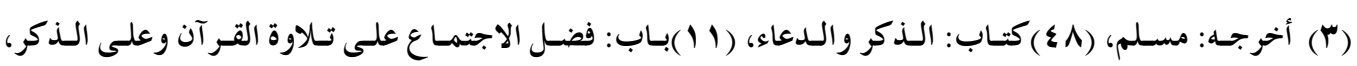




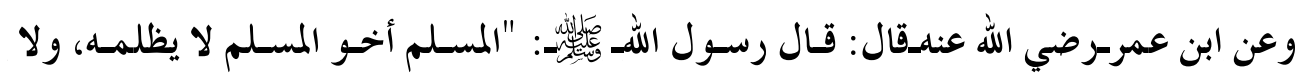

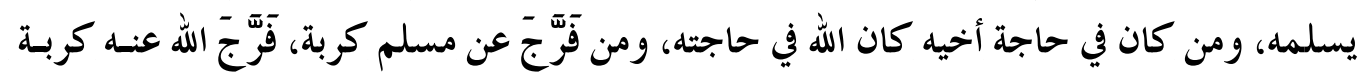

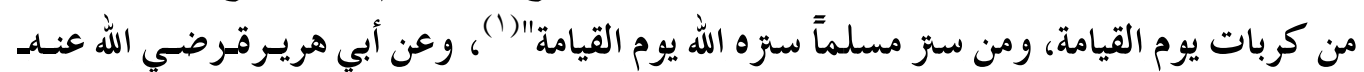

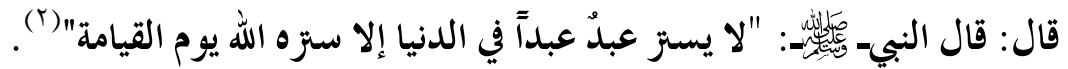

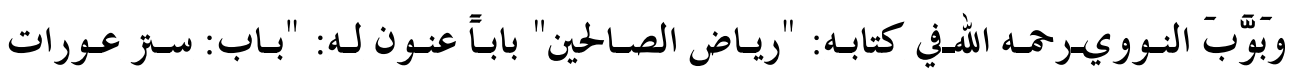
المسلمين، و النهي عن إشاعتها لغير ضرورة"(؟). الأصل الثالث: تحريم النميمة.

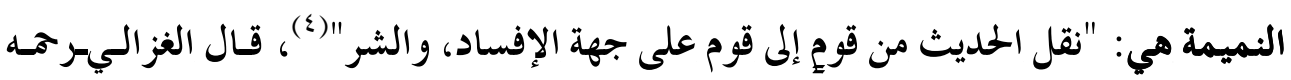

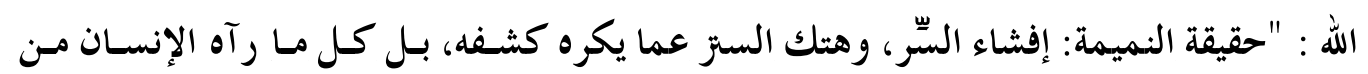
أحوال الناس مما يكره، فينبغي أن يسكت عنه إلا مـا في حكايتسه فائسدة لمسـلم، أو دفع لمعصسية" (0)

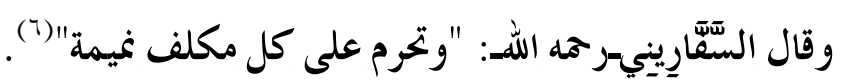
لقد نبّه الله ـ سبحانه وتعالمى ـ على مسؤولية الكلمة، وأهميتها، وضرورة محاسبة المـرء على مـا

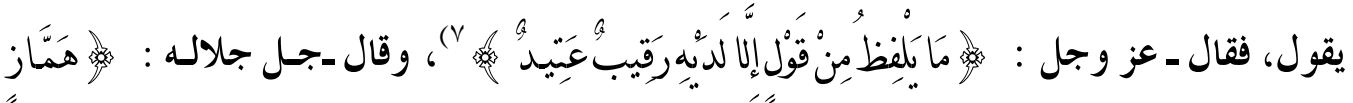

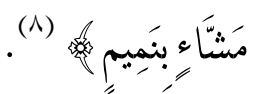

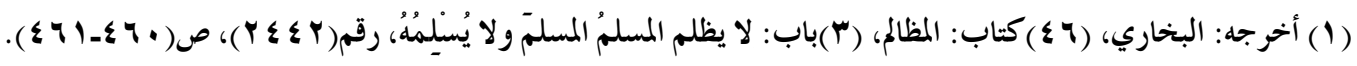

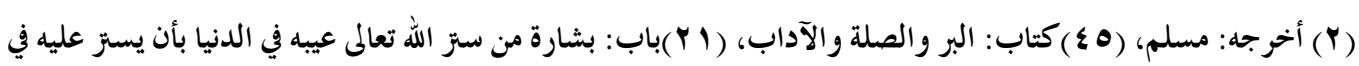

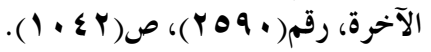

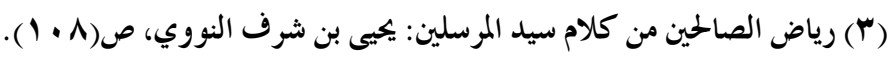

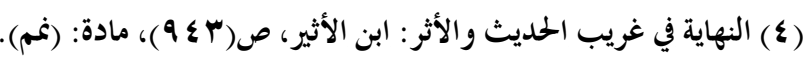

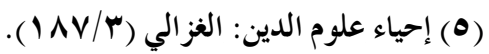

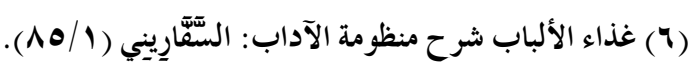

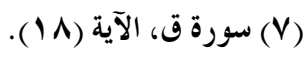




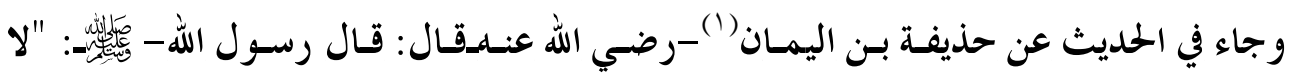

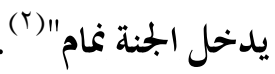

ولا يخفى ما للكلمة من بُعدٍ شرعي في حياة المسلم، فالإنسان يستشعر أهمية الكلمة بالتأمل في في آثارها العظيمة في واقعه الذي يعايشه.

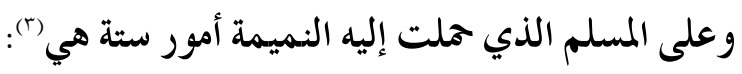

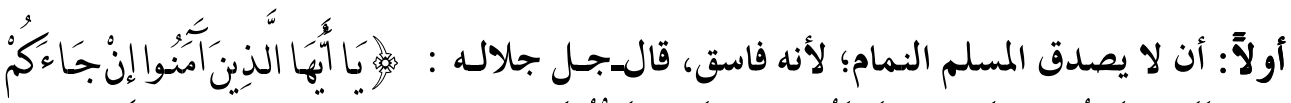

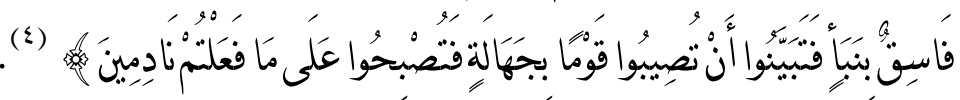

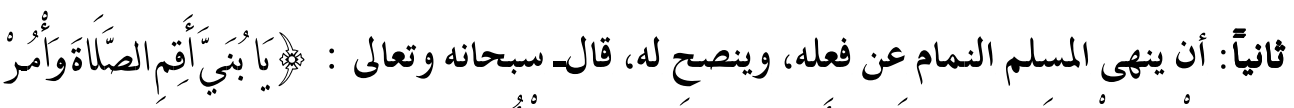

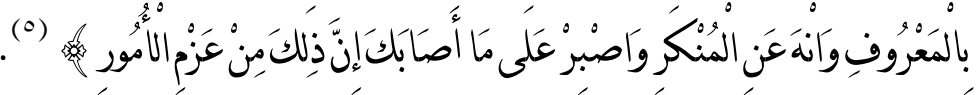

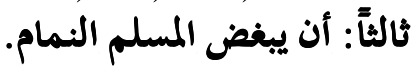

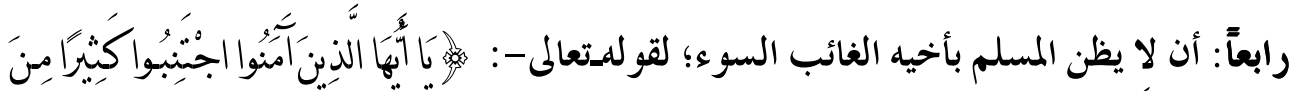

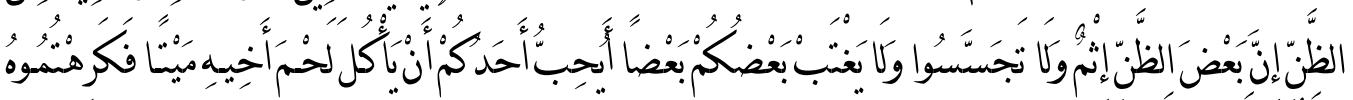

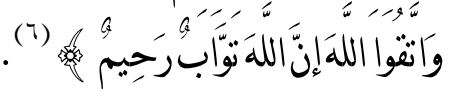

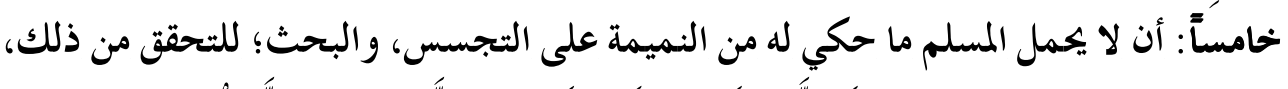

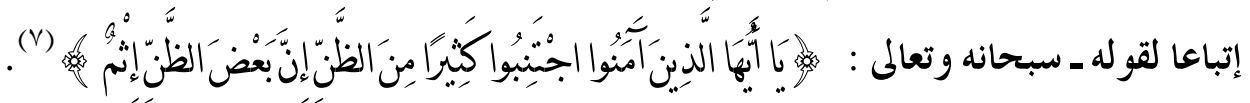

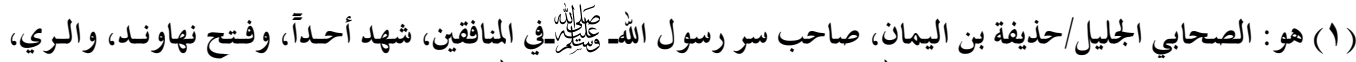

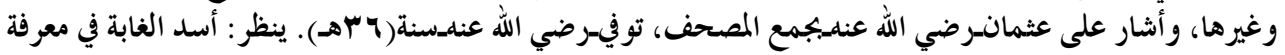

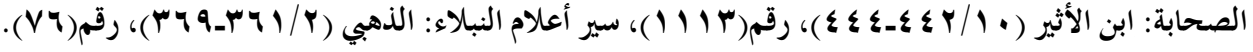

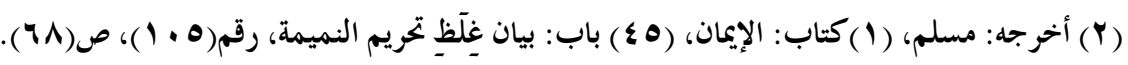

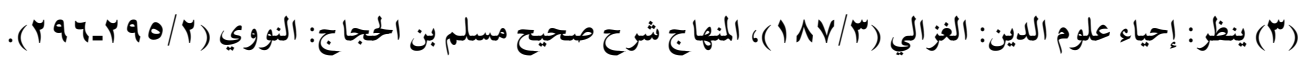

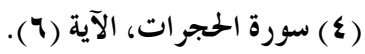

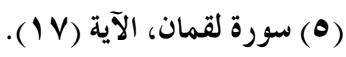

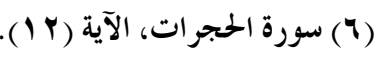

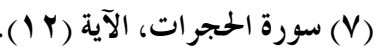


وإذا دعت المصلحة والحاجة إلى نقل حديث الآخرين، فلا مـانع مـن ذلك، قـال النسوويـرحمـه.

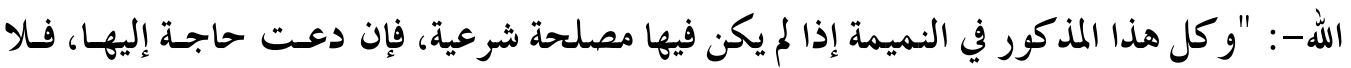

\section{الأصل الر ابع: تحريم الغيبة.}

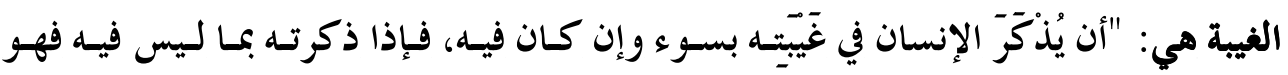

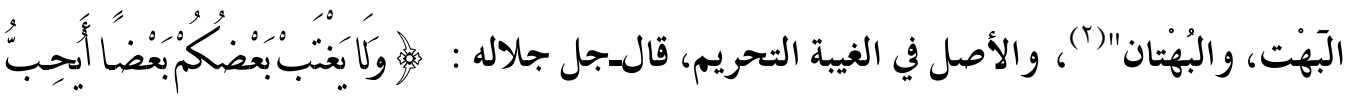

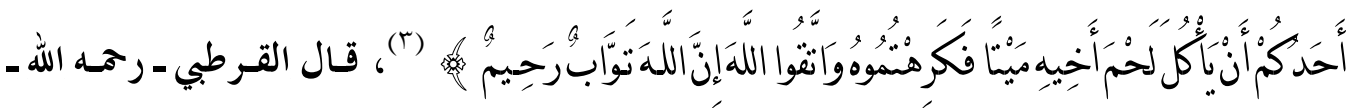
"لا خلاف أن الغيبة من الكبائر، وأن من اغتاب أحداً عليه أن يتوب إلى اللـعز وجلـ"(๕).

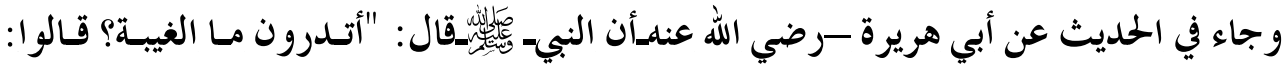
الله ورسوله أعلم. قال: "ذكرك أخاك بما يكره"، قيل: أفرأيت إن كـان في أخسي مـا أقول ؟. قـال: "إن كان فيه ما تقول فقد اغتبته، و إن لم يكن فيه فقد بَمََّّهُ"(•). ويستثنى من أصل تحريم الغيبة أمور تباح لغرض صحيح شرعي، لا يمكن الوصول إليه إلا بها، الأول: التظلم، فيجوز للمظلوم أن يتظلم إلى من يملك القدرة على نصـرته، وإنصـافه، فيقـول: ظلمني فلان بكذا.

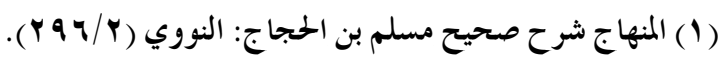

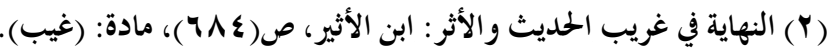

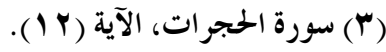

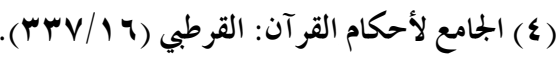

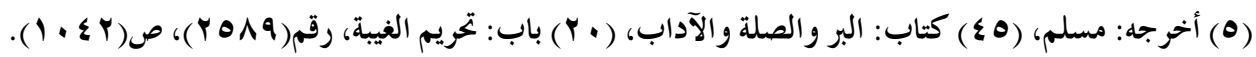

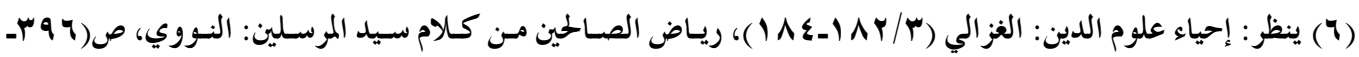


الثاني: الاستعانة على تغيير المنكر، ورَّّ العاصسي إلى الصـواب، ويكسون مقصسوده التوصـل إلى إلى

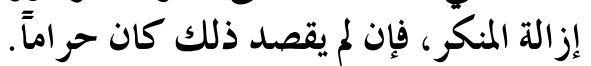

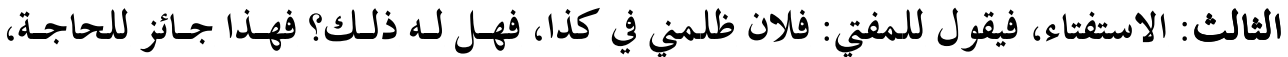

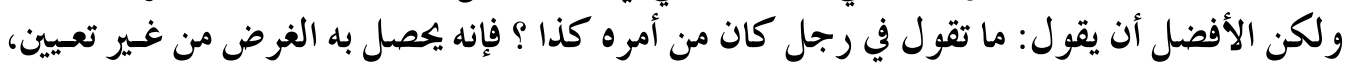
ومع ذلك فالتعيين جائز.

الرابع: تحذير المسلمين من الشر، ونصيحتهم.

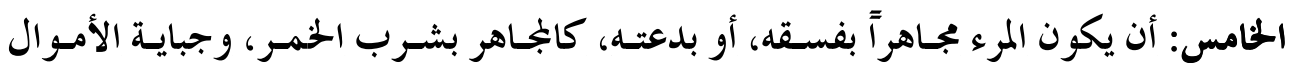

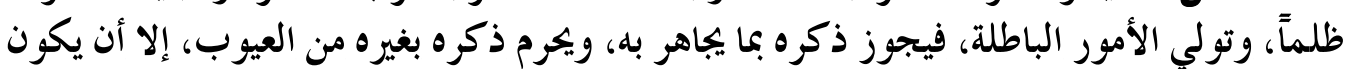

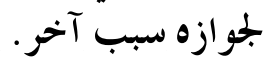

السادس: التعريف، فإذا كان الشخص معروفاً بلقب، كـالأعمش، والأصسم، والأحسول، جـاز

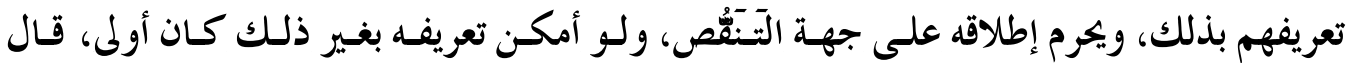
النوويـرحمه اللهـ: "فهذه ستة أسباب ذكرها العلماء، وأكثرها مجمعُ عليه، ودلائلها من الأحاديــثـ

الصحيحة مشهورة" (1).

\section{الأصل الحامس: وجوب أداء الشهادة.}

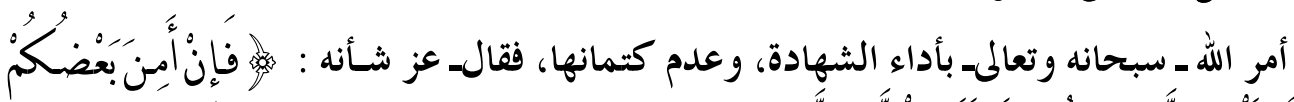

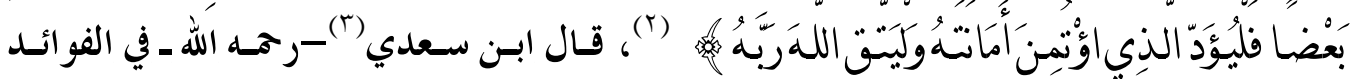
المستنبطة من الآية الكريمة: "ومنها: تحريم كتم الثهادة، وأن كاتمها قد أثم قلبـه، الـذي هـو ملـك الأعضاء، وذلك لأن كتمها كالشهادة بالباطل، والزور، وفيها ضياع الحقوق، وفسـاد المعـاملات، والإثم المتكرر في حقه، وحق من عليه الحتق" (๕). وكم من الحقوق العظيمة التي يتطلب الوصول إليها شهادة الطبيب أمام القضاء ؟!.

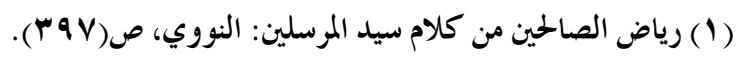

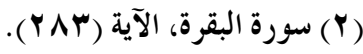

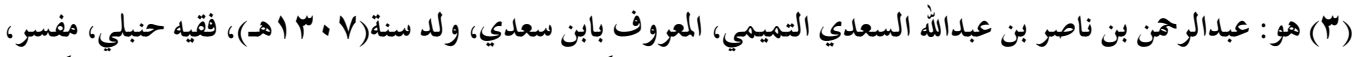

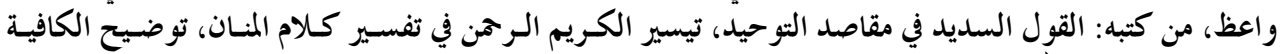

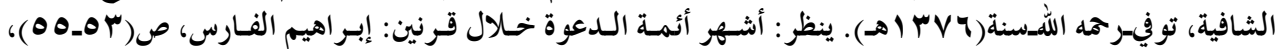

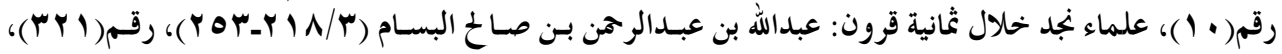

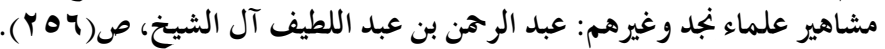

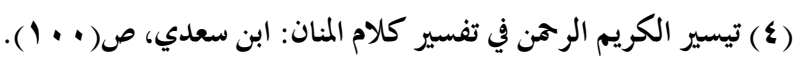


الأصل السادس: وجوب أداء الأمانة، وحفظ العهود، والمو اثيق.

من أخلاق المسلم الفاضلة اتصافه بالأمانة، فهو من أبعد الناس عن الغش، والخيانة، يحفظ للآخرين حقوقهم، ويكرص على حفظ العهود، والمواثيق التي يقطعها على نفسه؛ امتثالًا لقوله ـ

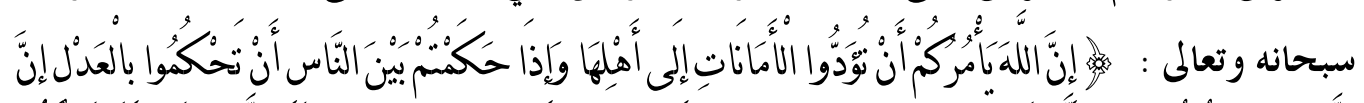

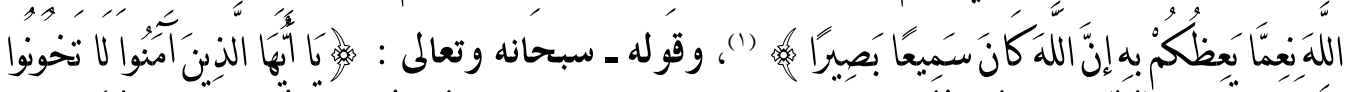

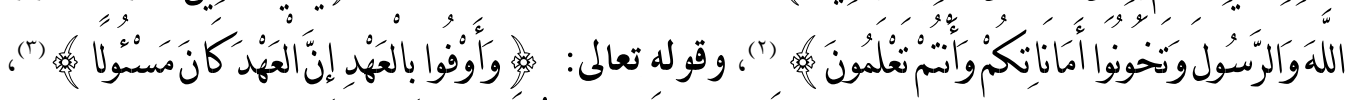

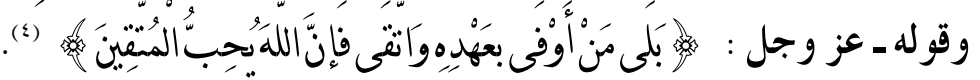

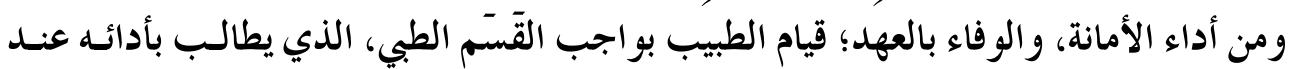

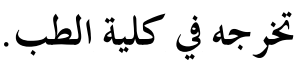

\section{الأصل السابع: تعارض المصالح والمفاسد.}

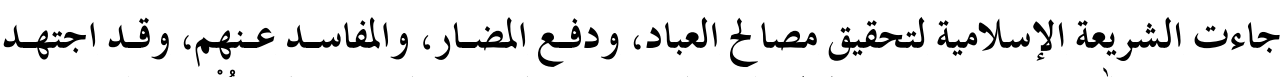

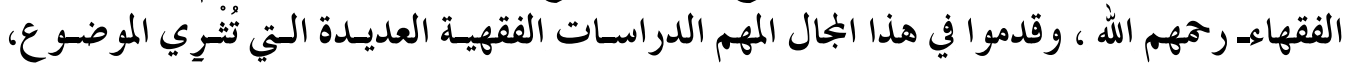
ومن جملة ذلك عدد من القواعد الفقهية منها:

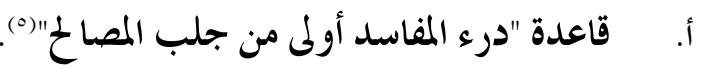

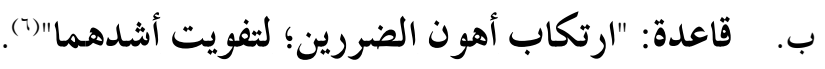

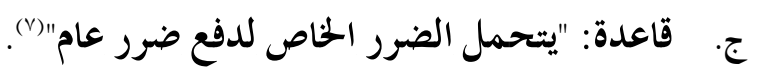

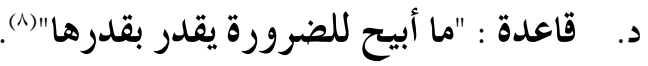

$$
\begin{aligned}
& \text { (1) سورة النساء، الآية (ه). }
\end{aligned}
$$

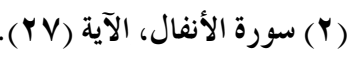

$$
\begin{aligned}
& \text { (ץ) سورة الإسراء، الآية (ع س). } \\
& \text { (ع) سورة آل عمران، الآية (V)). }
\end{aligned}
$$

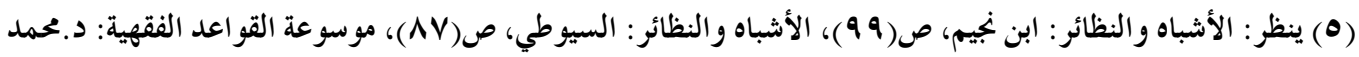

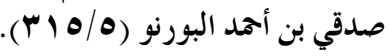

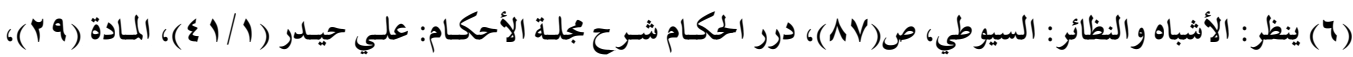

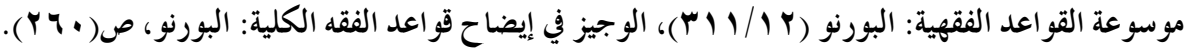

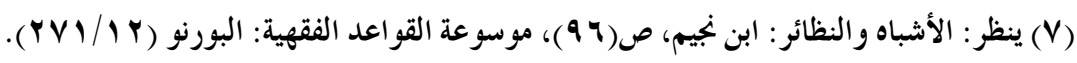
$-9 \cdot r-$

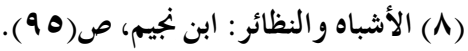




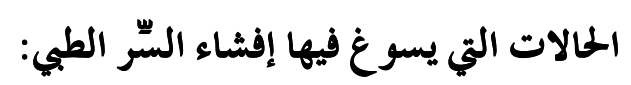

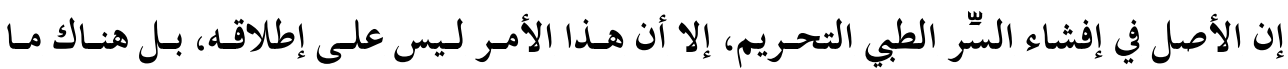

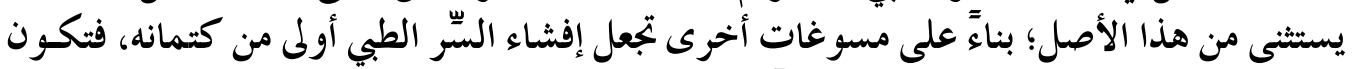
المصلحة في ذلك أعظم، وأجل، وأكثر نفعاً.

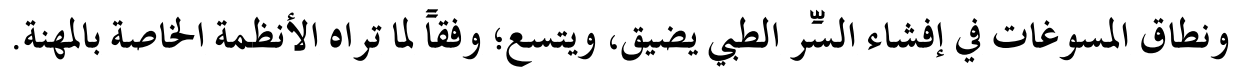

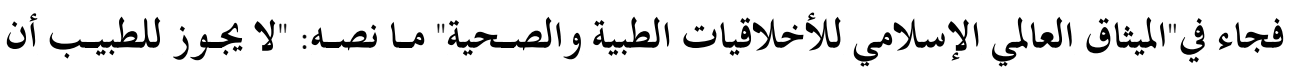

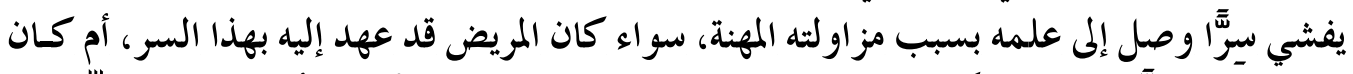

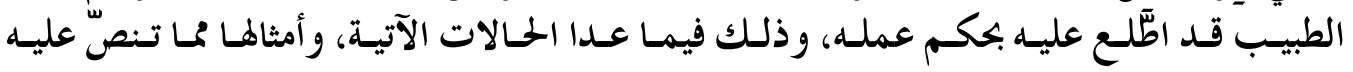

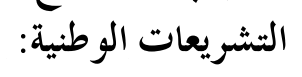

(أ) إذا كان إفشاء السر بناءَ على طلب صاحبه خطيَّا، أو كان في إفشائه مصـلحة للمريض، أو مصلحة للمجتمع. (إذان إناء

(ب) إذا كانت القو انين النافذة تنصُّ على إفشاء مثل هذا السر، أو صدر قرار بإفشائه من جهـة

(ج) إذا كان الغرض من إفشاء السر منع وقوع جريمة، فيكون الإفشاء في هـذه الحسال للسـلطة الرسمية المختصة فقط.

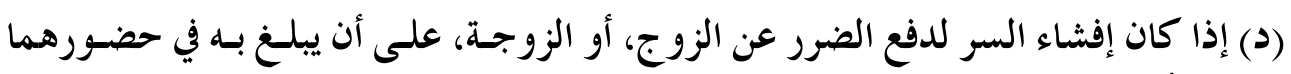
معاً، وليس لأحدهما دون الآخر.

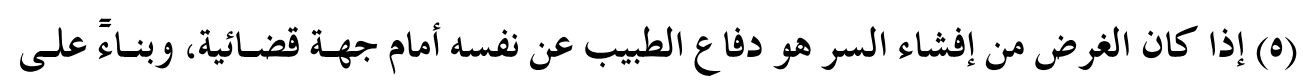

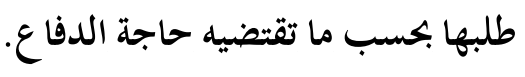

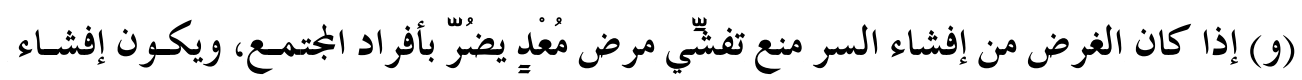

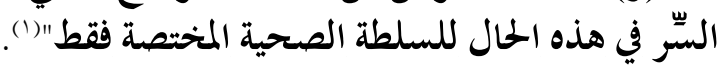

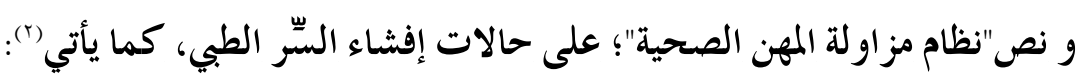

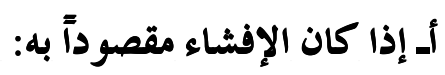

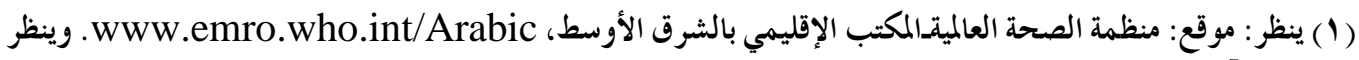

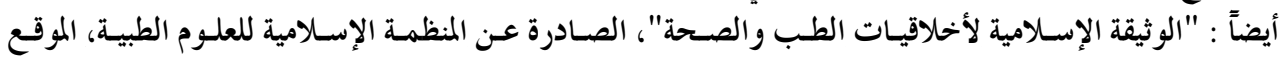
الالكتروني: WWw.islamset.com

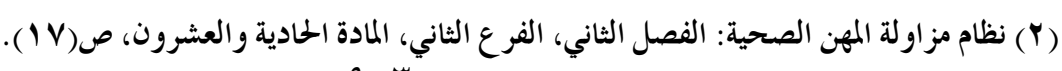
- $9 \cdot r$ - 


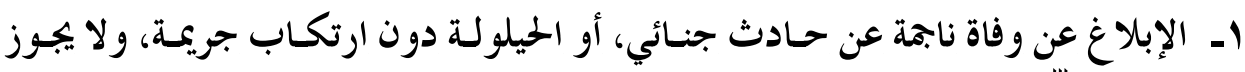

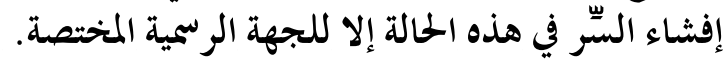

$$
\text { r. ب. الإبلا غ عن مرض سار، أو معد. }
$$

بــ دفع الممارس لاتهام وجهه إليه المريض، أو ذووه يتعلق بكفايته، أو بكيفية ممارسته لمهنته.

بـ إذا وافق صاحب السر كتابة على إفشائه، أو كان الإفشاء لذوي المريض مفيداً لعلاجه.

ج- إذا صدر له أمر بذلك من جهة قضائية.

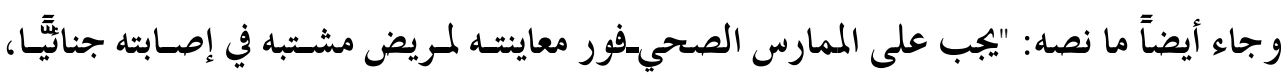

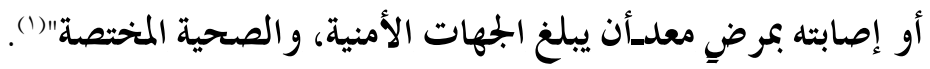

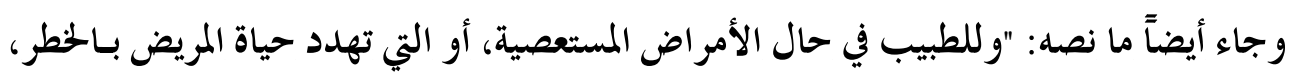

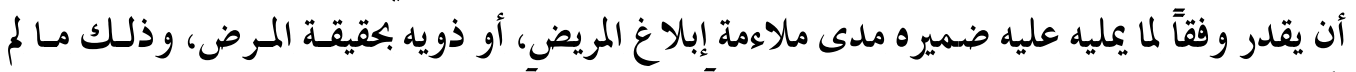

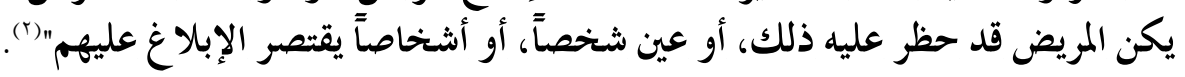

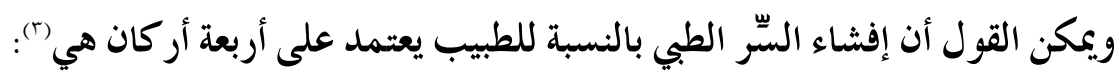

الأول: الحفاظ على مصلحة المريض.

الثاني: الحفاظ على مصلحة الجتمع.

الثالث: الحفاظ على مصلحة أحد الأفراد.

الرابع: الحفاظ على مصلحة الطبيب، أو مهنة الطب.

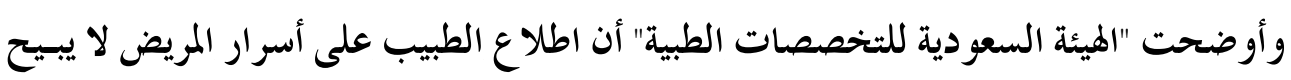

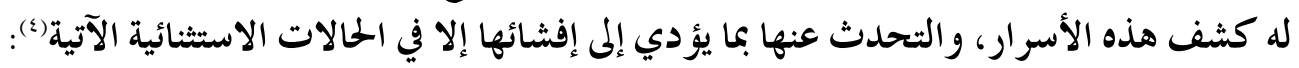

(1) نظام مزاولة المهن الصحية: الفصل الثاني، الفرع الأول، المادة الحادية عشرة، ص(• (1).

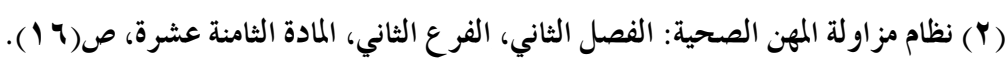

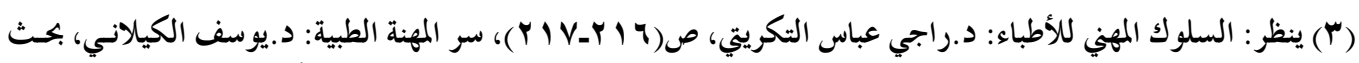

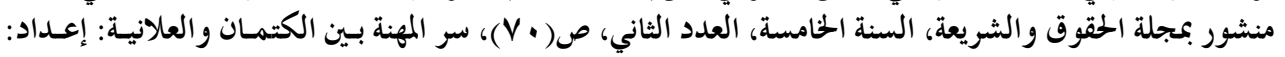

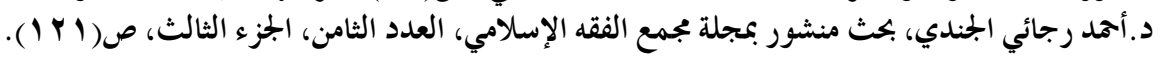

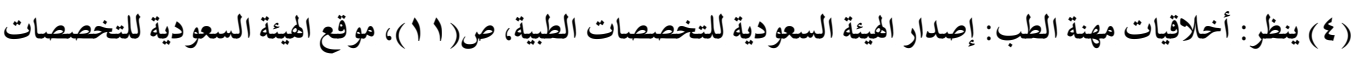
الطبية على الشبكة العالمية للمعلومات (الإنترنت): WWW.scfhs.orq 


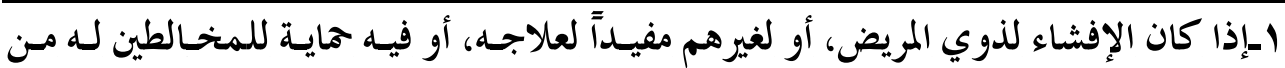

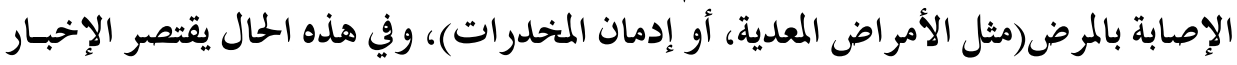

$$
\text { على من يمكن أن يضار. }
$$

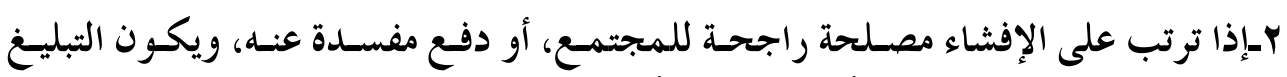
للجهات الرسمية المختصة، وأمثلة ذلك ما يأتي:

$$
\text { الإبلا غن عن وفاة ناجة عن حادث جنائي، أو للحيلولة دون ارتكاب جريمة. }
$$

إذا طلب منه ذلك من جهة قضائية.

دفع تهمة مو جهة إلى الطبيب من المريض، أو ذويه تتعلق بكفاءته، أو كيفية ممارسته لمهنته، على إلى

أن يكون الإفشاء أمام الجهات الرهمة الرسية.

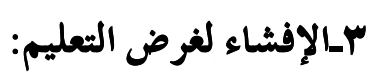

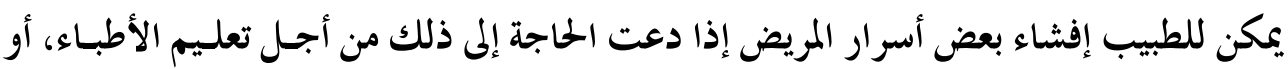

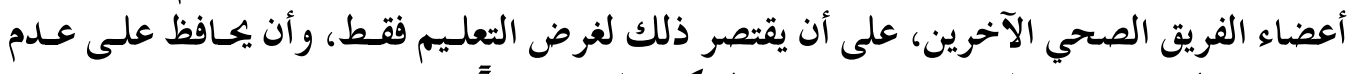

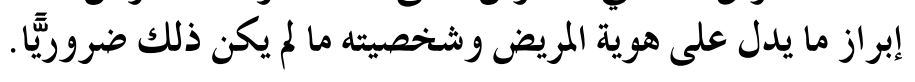

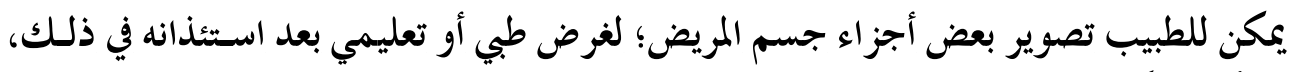

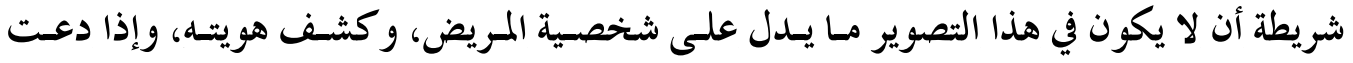

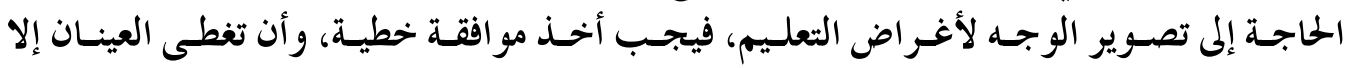
للضرورة العلمية.

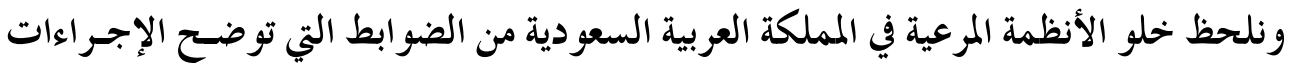

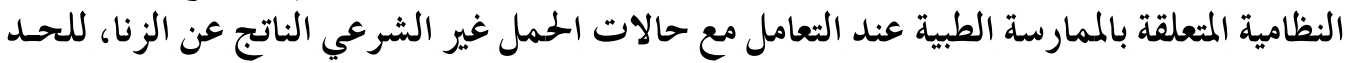

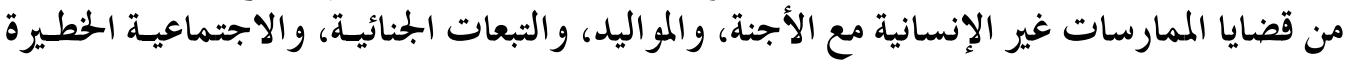

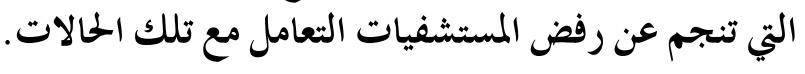




$$
\text { المطلب الثاني }
$$

\section{عقوبة الطبيب إذا أفشى السّر الطبي}

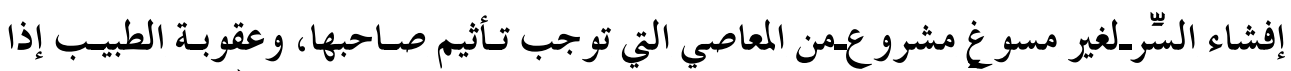

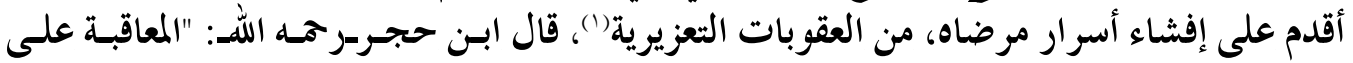

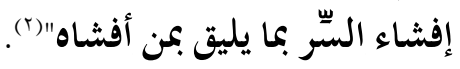

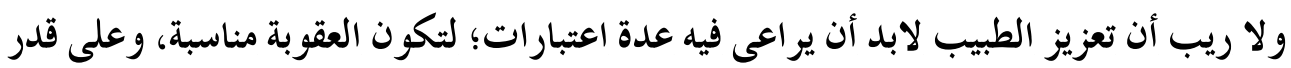

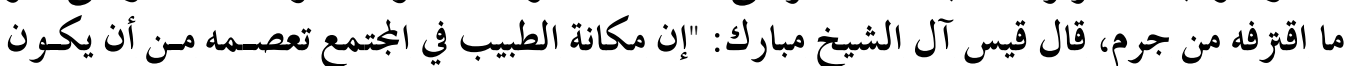

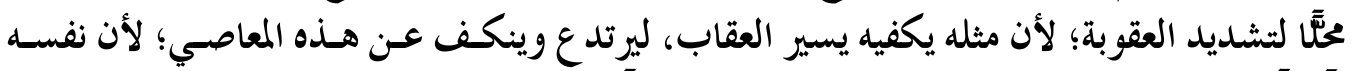

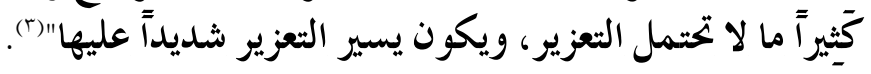
ونص "نظام مز اولة المهن الصحية" بالمملكة العربية السعودية على العقوبات التأديبية للممـارس

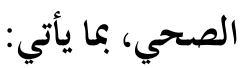

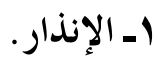

Y.غر امة مالية لا تتجاوز عشرة آلاف ريال.

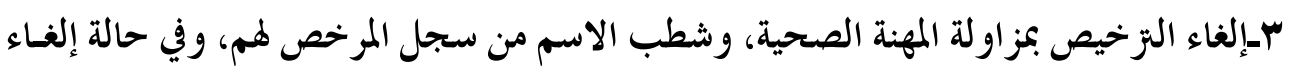

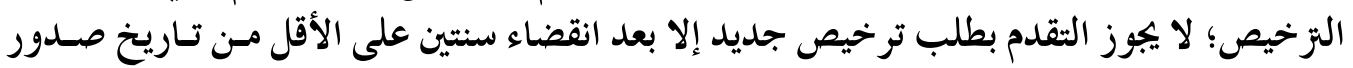

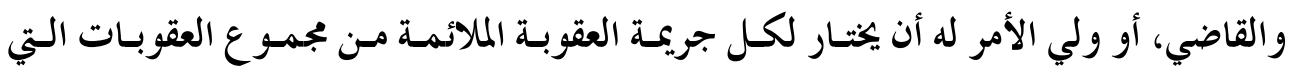

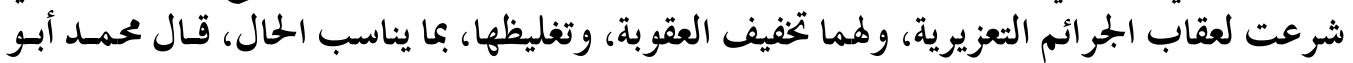

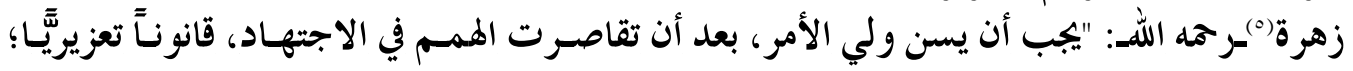

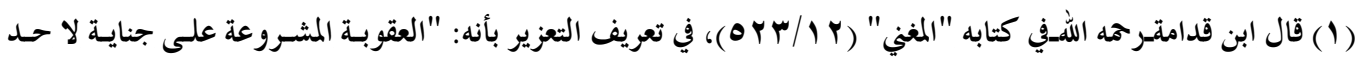
فيها".

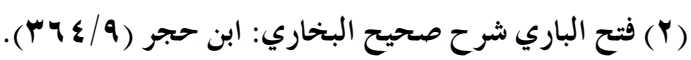

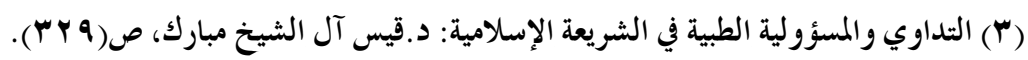

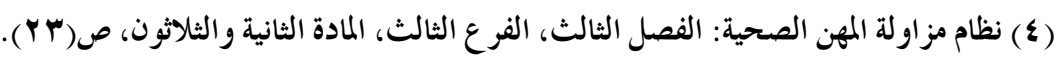

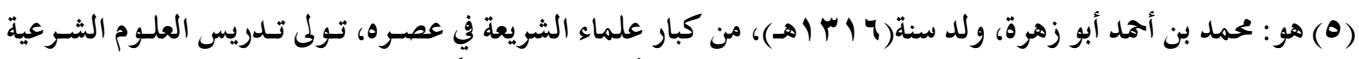

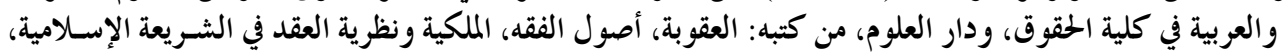

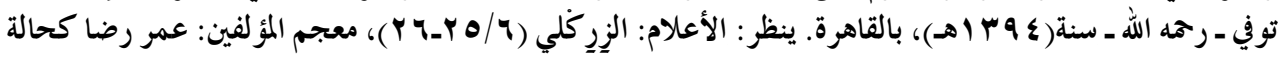


لحماية الأموال، والأخحلاق، والنظام، ويرتب فيه العقوبات على حسب مقدار الاعتداء على المصالح

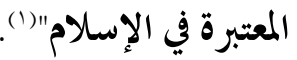

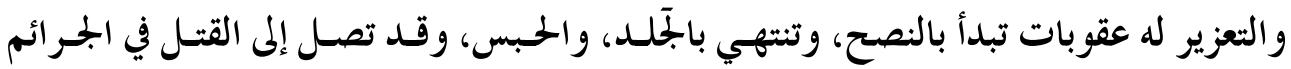

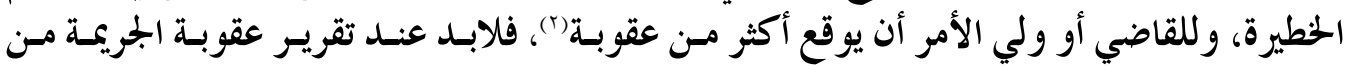
اعتبار أمور ثلاثة) آناخي الأول: مقدار الأذى الذي ينزل بالجني عليه. الثاني: مقدار التزويع والإفزاع العام الذي تحدثه الجريمة. الثالث: مقدار ما فيها من هتك لحمى الفضيلة الإسلامية، ومقدار الزجر، والرد ع في العقوبة.

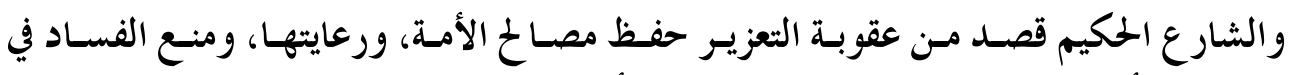

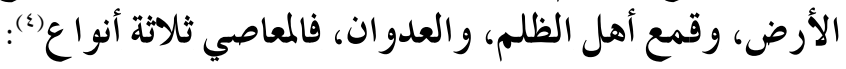

$$
\begin{aligned}
& \text { أـ نوع فيه الحد، ولا كفارة فيه، كالسرقة، والقذف، وشرب الحمر. } \\
& \text { بـ نوع فيه الكفارة، ولا حد فيه، كالوطء في نهار رمضان. } \\
& \text { ج- نوع لا حد فيه، ولا كفارة، كقُبْلة المر أة الأجنبية. }
\end{aligned}
$$

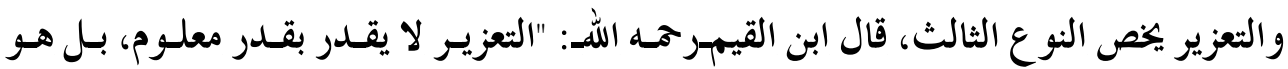

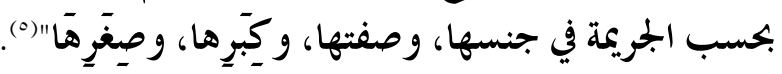

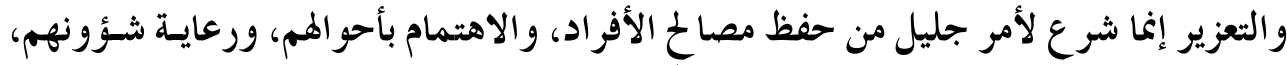

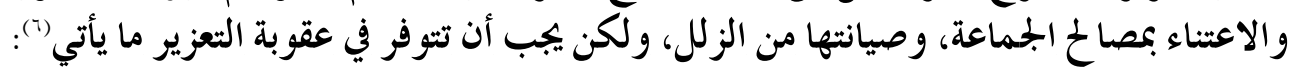

أ أن يكون الباعث عليها حماية المصالح الإسلامية المقررة، لا حماية الأهواء، والشهوات.

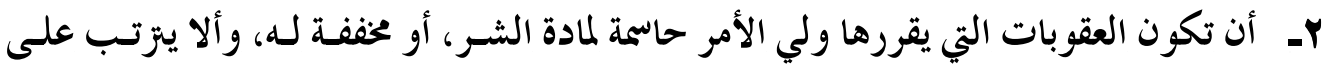

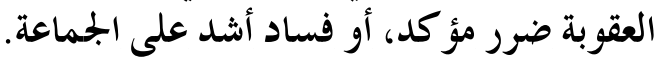

$$
\text { (1) العقوبة: أبو زهرة، ص(79). }
$$

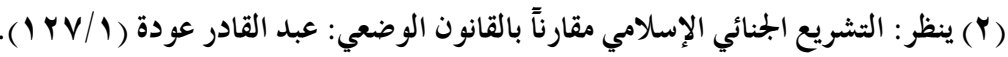

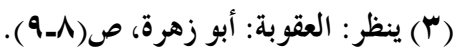

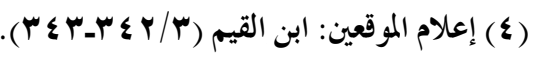

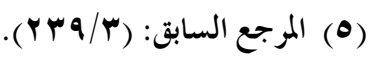


rــ أن تكون هناك علاقة مناسبة بين العقوبة، والجريمة، فلا يسرف في عقاب، ولا يستهين بجريمة. عـ المساواة، و العدالة بين جميع أفراد الأمة.

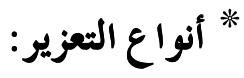

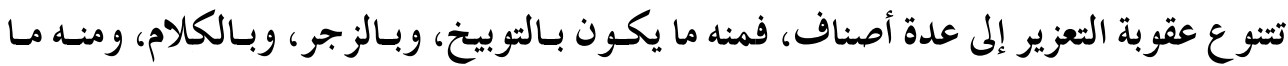

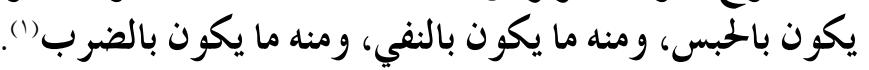

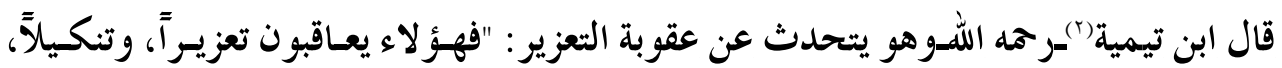

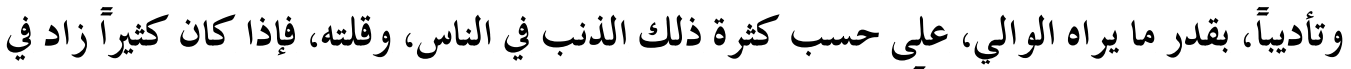

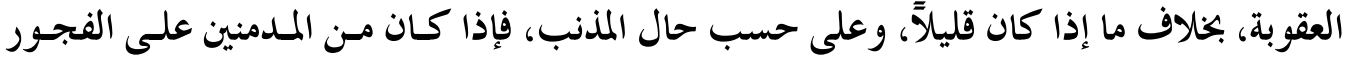

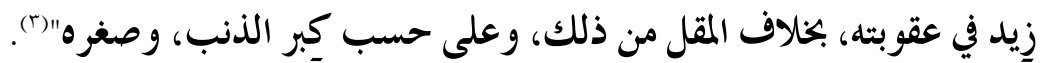
وفيما يأتي أهم أنواع التعزير مع التنبيه إلى أن أنو اعه كثيرة، يختار منها القاضـي مـا يــراه صـالحاً

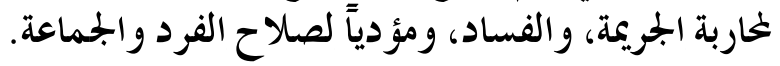

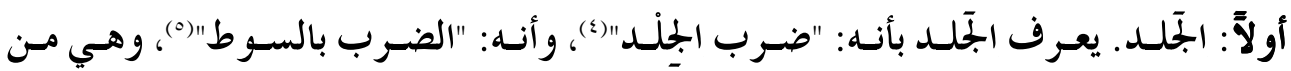

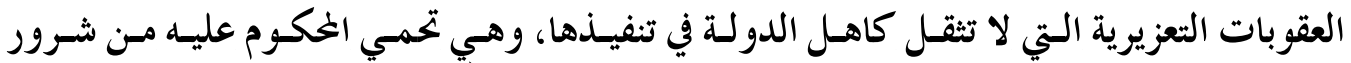

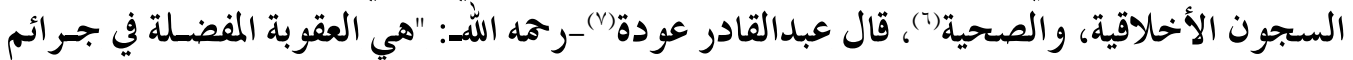

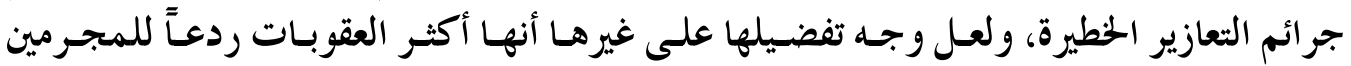

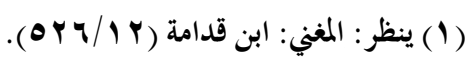

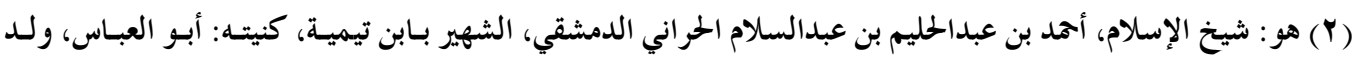

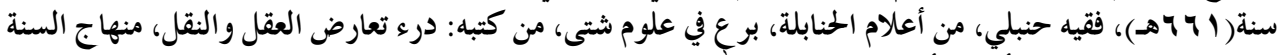

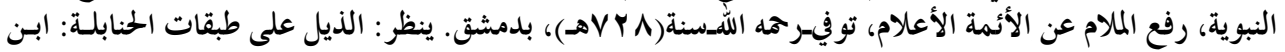

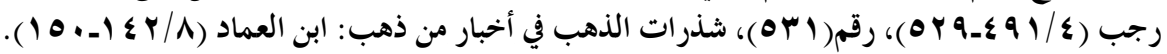

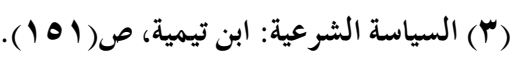
( ( ) التعريفات: الجر جاني، ص(ع • (1).

(•) معجم لغة الفقهاء: وضعه: أ.د. محمد رواس قلعة جي، د. دحامـد صـادق قنسيبي، أ. قطـب مصطفى سـانو، ص(ع ع ع ا ).

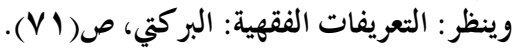

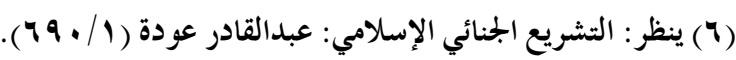

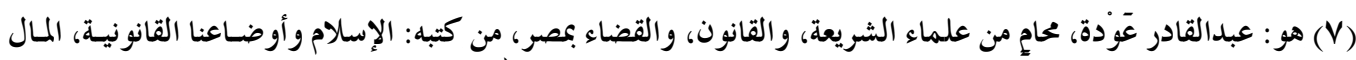

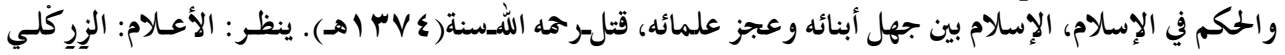

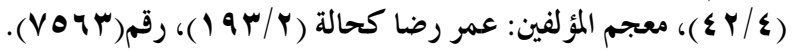




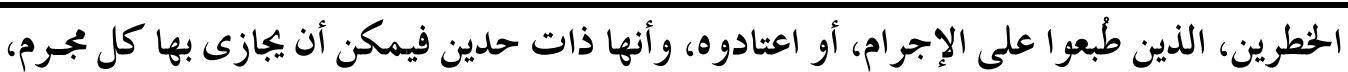

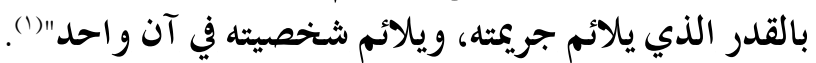

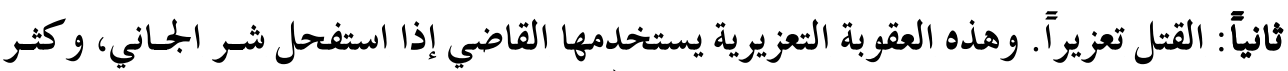

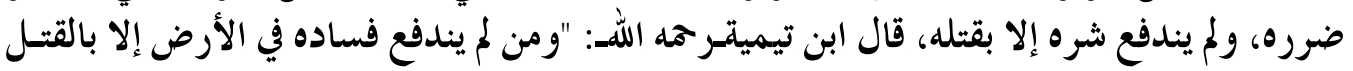

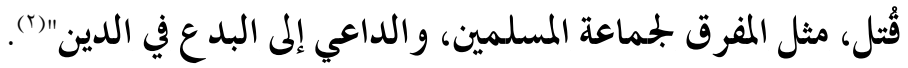

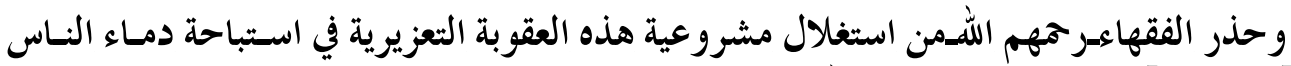

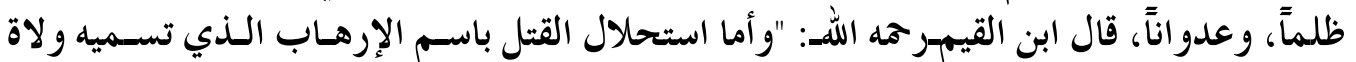

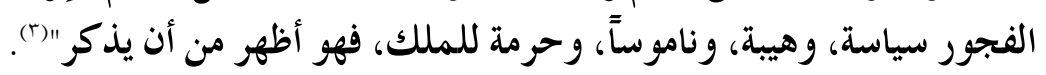
ثالثاً: الحَّس. يعرف الحَّس بأنه: "الإمساك في المكان، والمنع من الحخروج" (s).

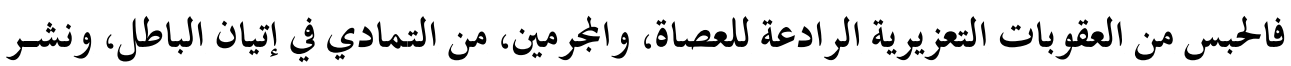

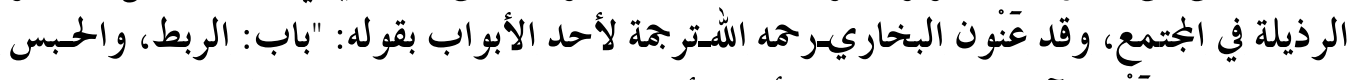

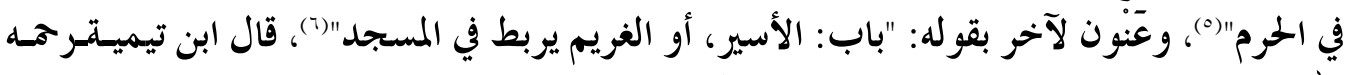

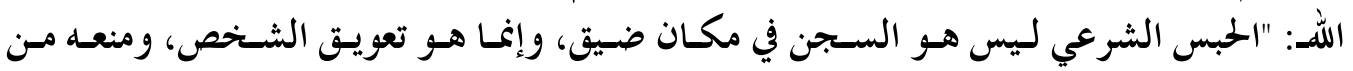

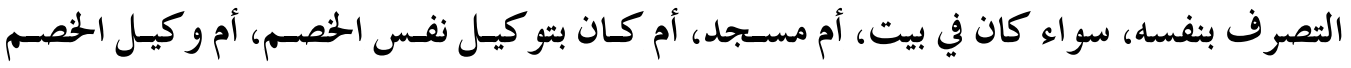

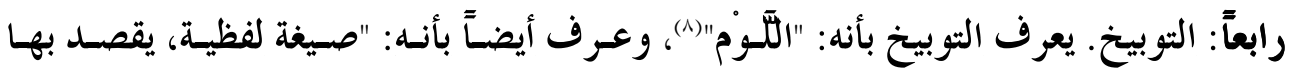

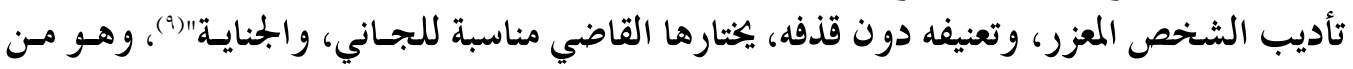

(1) ينظر : التشريع الجنائي الإسلامي: عبدالقادر عودة (1/ • 9 ).

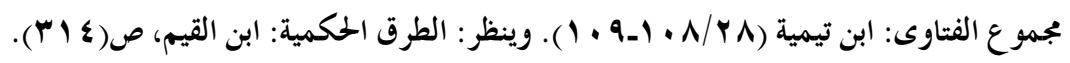
إعلام الموقعين: ابن القيم (ع / • به (ه).

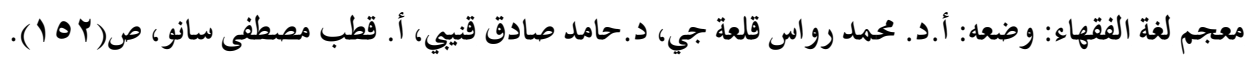

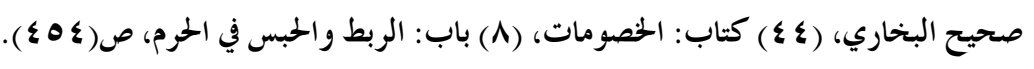
صحيح البخاري، (N) كتاب: الصلاة، (V0) باب: الأسير أو الغريم يربط في المسجد، ص(9 + (1).

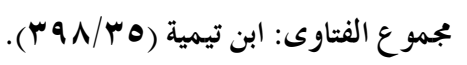

معجم لغة الفقهاء: وضعه: أ.د. محمد رواس قلعة جي، د. حامد صادق قنيبي، أ.قطب مصطفى سانو، ص( • ب I).

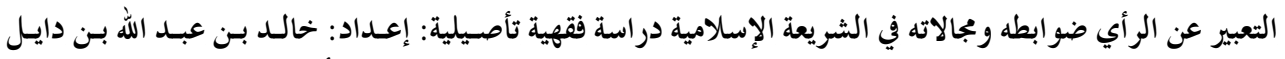

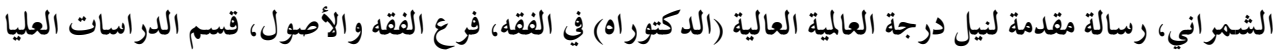

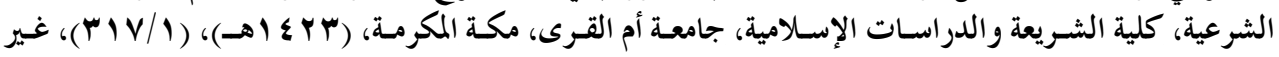




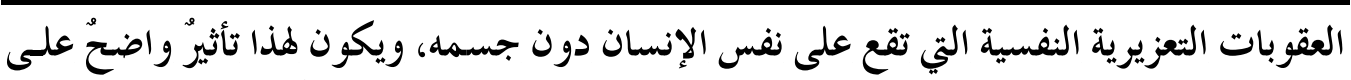

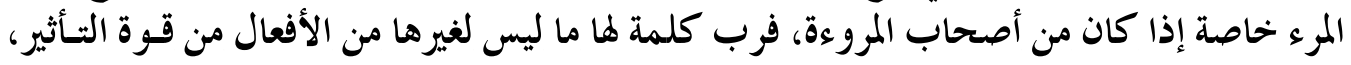

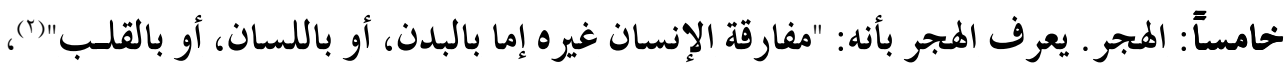

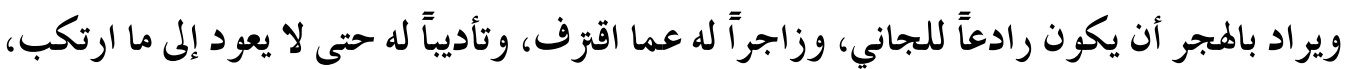

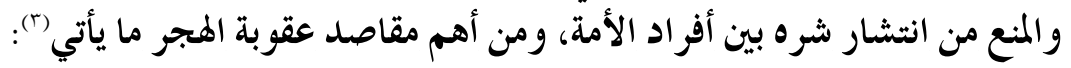
أـأنه من العقوبات الثرعية التي يوقعها المسلم على أهل الأهواء على وجه التأديب حتى يتسوب المبتدع، ويفيء إلى أمر الله.

بـ تحذير المسلمين من الوقوع في البدعة، وإيقاظ نفوسهم من موادعة المبتدعة. ج- قمع المبتدع، وزجره؛ لنضعف بدعته، وتنهار دعوته.

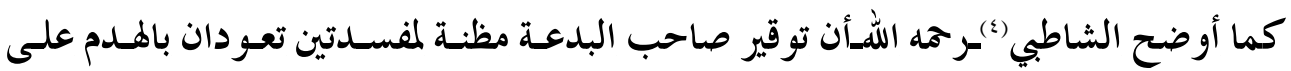
الإسلام، وهما

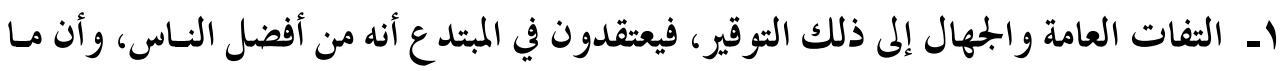

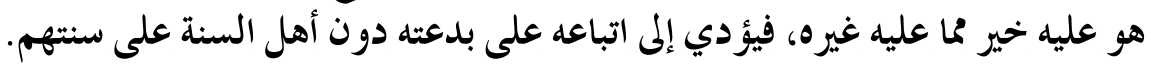

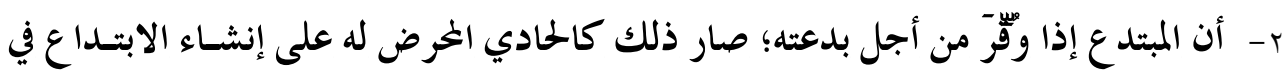
كل شيء.

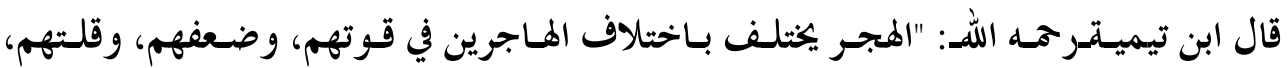

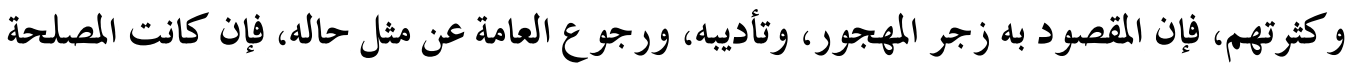

ينظـر : العقوبـة: أحسد فتحسي بهنسـي، ص( • ع ( )، المسدخل لدراسـة الشـريعة الإسـلامية: د.عبـدالكريم زيسـان،

ص(س معجم المصطلحات والألفاظ الفقهية: د.محمود عبد الرحن عبد المنعم (ب/ ج ع ع ).

ينظر : مطلع الفجر في فقه الزجر بالهجر : سليم بن عيد الهلالي، ص(9 ؟ ).

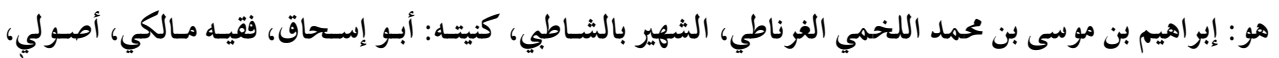

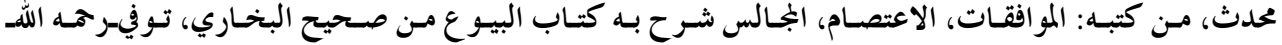

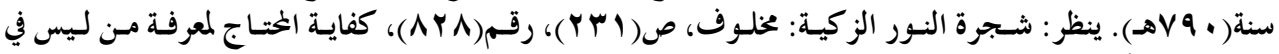

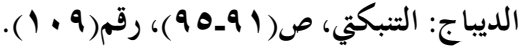




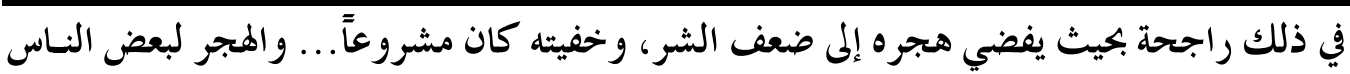
أنفع من التأليف" (1) فحكئ.

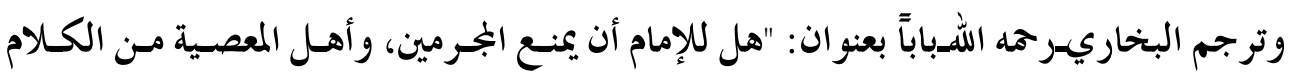

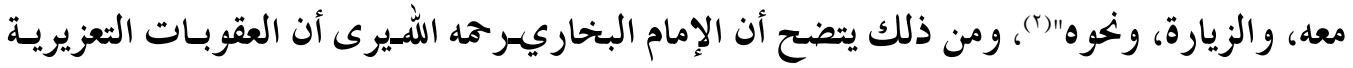

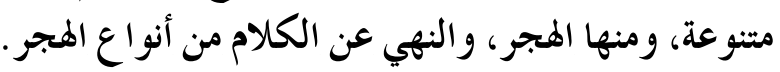

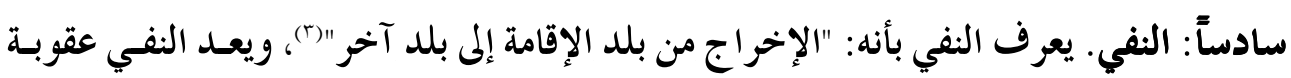

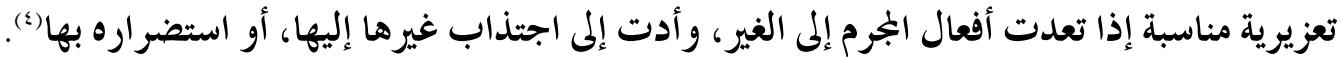
سابعاً: الشهيز · يعرف التشهير بأنه: "إثاعة السوء عن إنسان بين الناس"(ه). وهو من العقوبات التعزيرية النفسية، يقصد به التحذير من الجحاني، والدعوة إلى اجتنابه(ج)، قـال

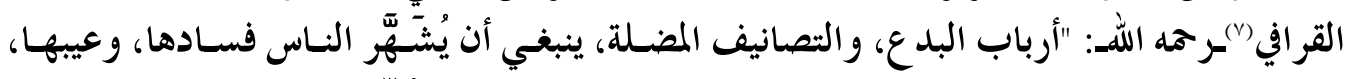

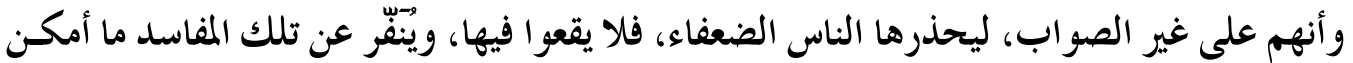

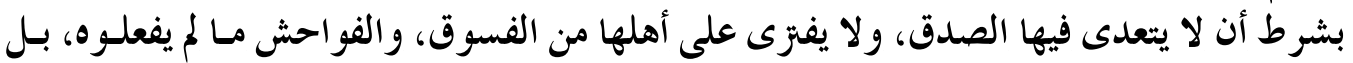

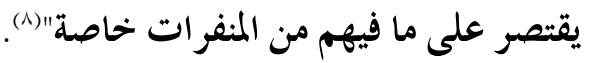

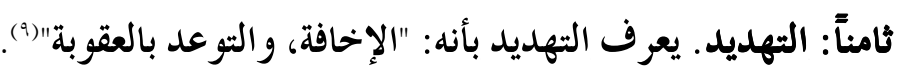

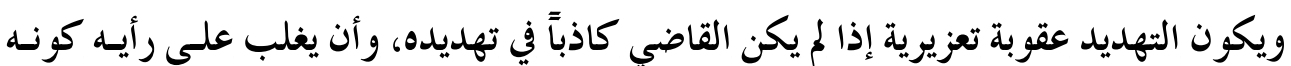

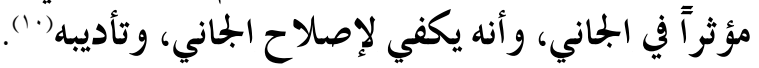

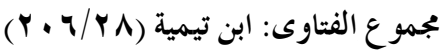

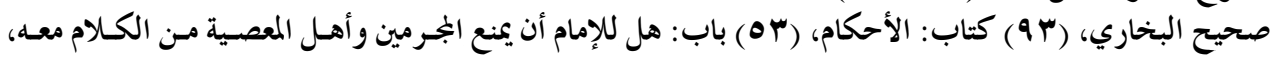

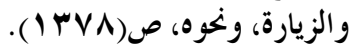

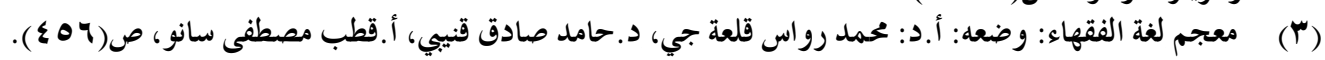

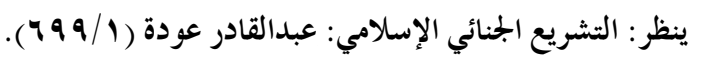

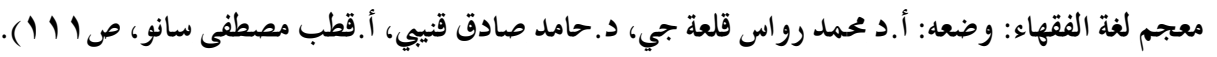

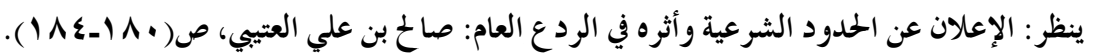

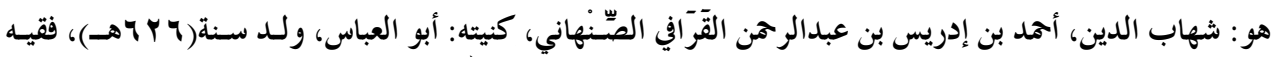

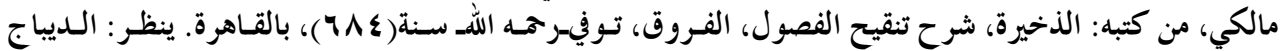

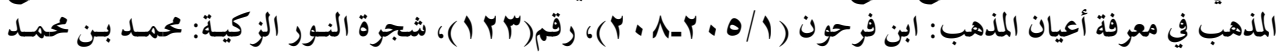

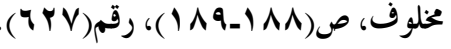

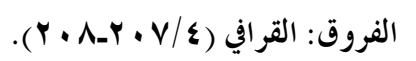

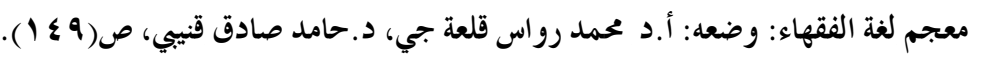

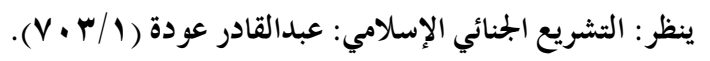




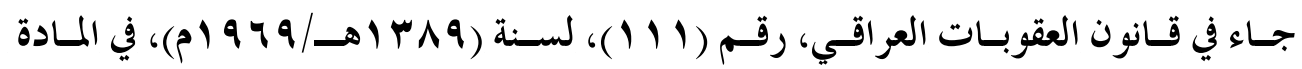

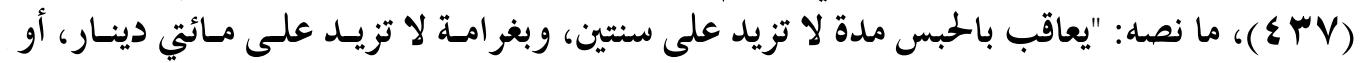

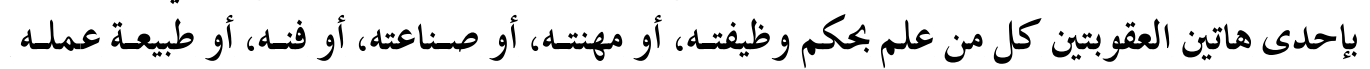

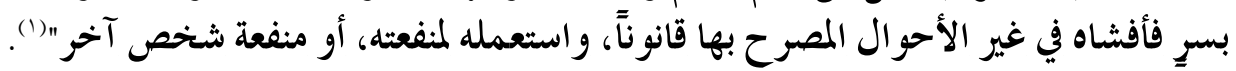

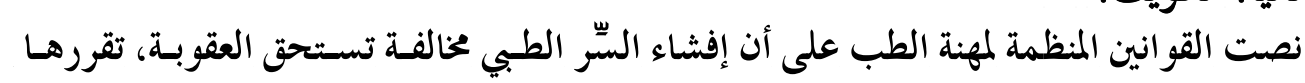
ثانياً: الكويت.

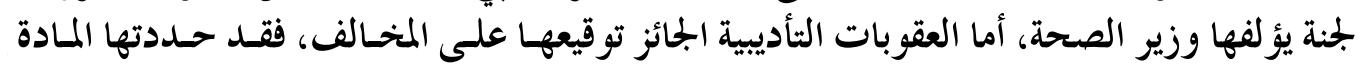

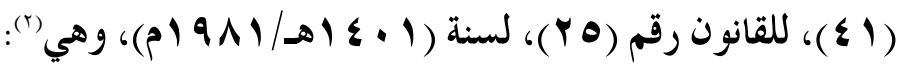

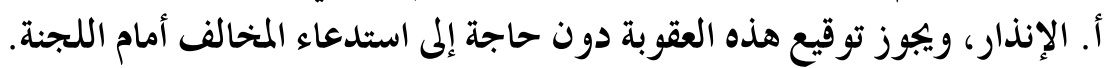

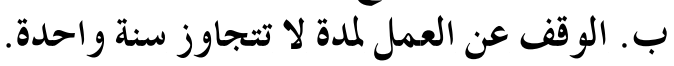

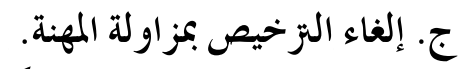

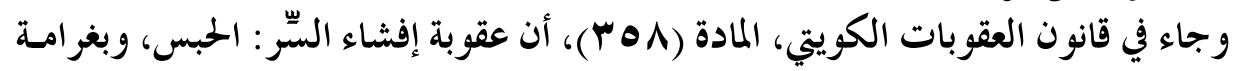

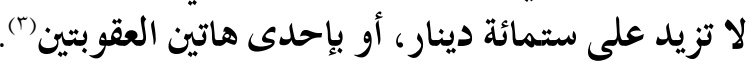
ثالثاً: مصر.

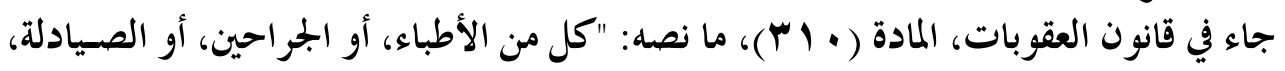

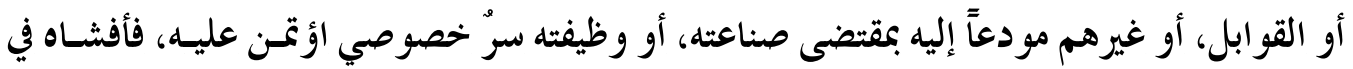

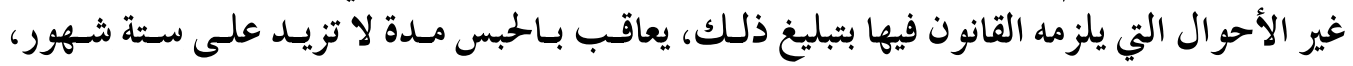

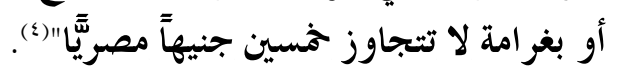
رابعاً: الأردن.

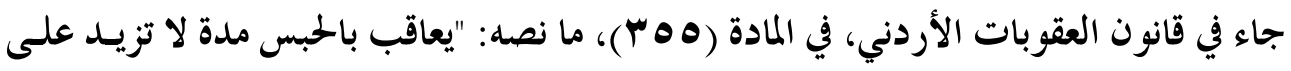

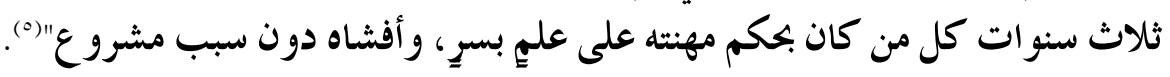

$$
\text { (1) الطب القضائي وآداب المهنة الطبية: د.ضياء نوري حسن، ص(ع • ع). }
$$

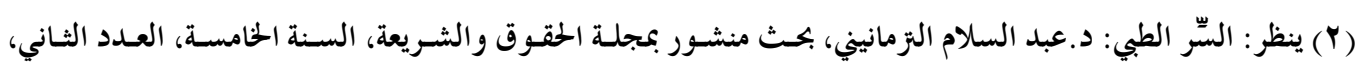

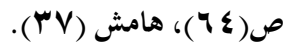

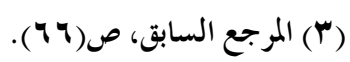

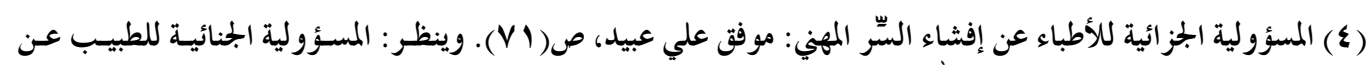

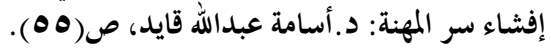

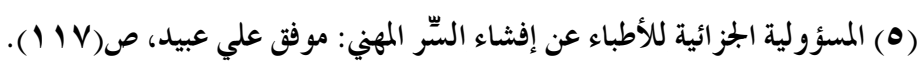


المطلب الثالث

\section{حكم تكرار إفشاء الطبيب للسر الطبي}

يجب على الطبيب أن يكون مخلصاً في مجال عمله، مهتماً غاية الاهتمام بكل مـا يتعلق بمريضسه، و الظروف الخيطة بطبيعة مرضه؛ ليتمكن من أداء رسالته بكل اقتدار، وأمانسة، فالأمانـة كـبيرة حسين

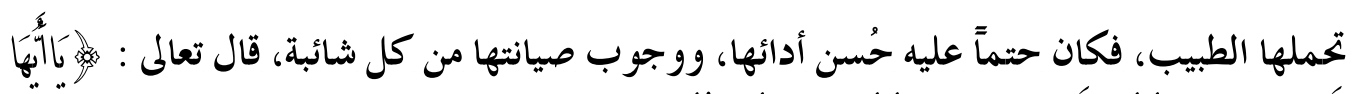

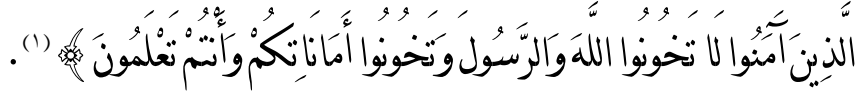

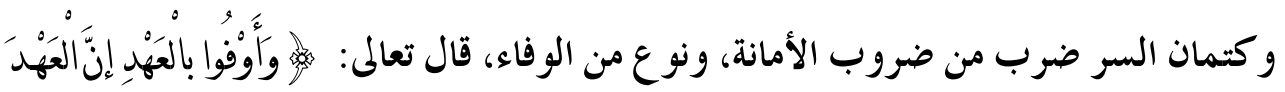

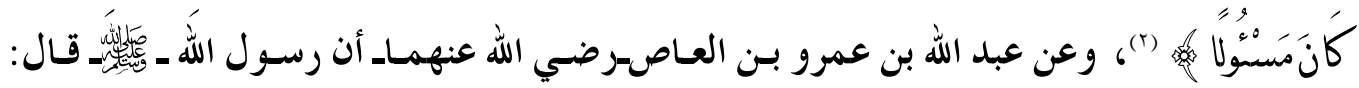

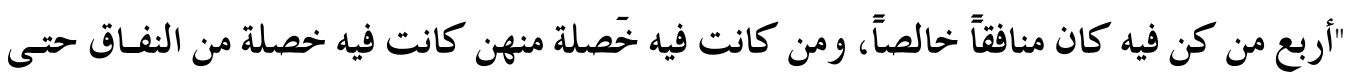
يدعها: إذا اؤتنن خان، وإذا حدث كذب، و إذا عاهد غدر، و إذا خاصم فجر "((). وقال عمر بن الخطابـرضي الله عنهـ: "لا تنظروا إلى صلاة أحد، ولا إلى صيامه، ولكن انظروا

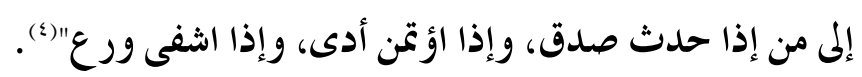

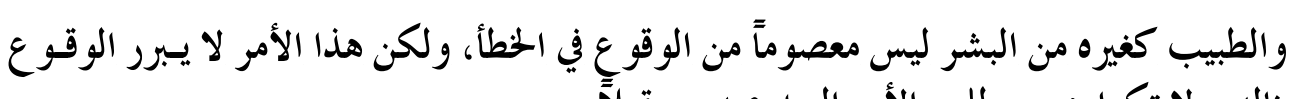
في أمثاله، ولا تكراره، ويتطلب الأمر البعد عنه مستقبلاً.

فالطبيب و اجبه يقتضي ممارسة عمله بإتقان، و العناية بالمرضى، وليس الحسديث عـن أمر اضـهم،

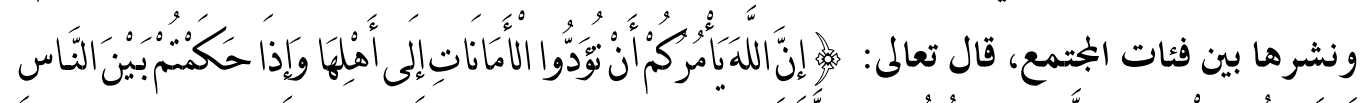

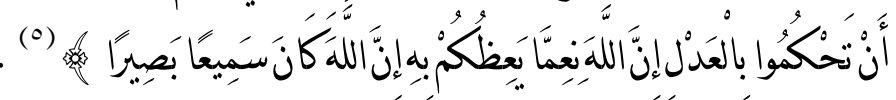

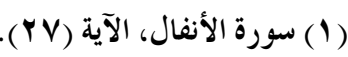

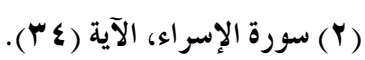

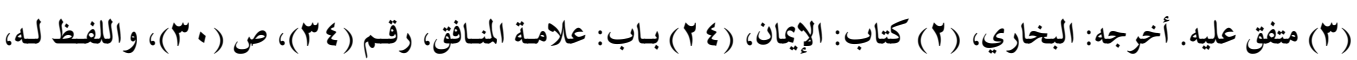

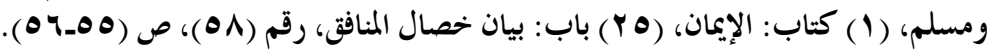

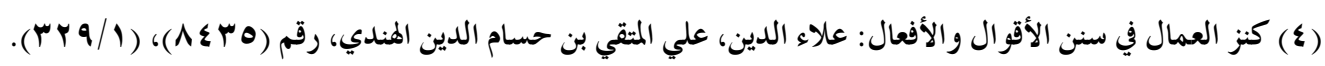




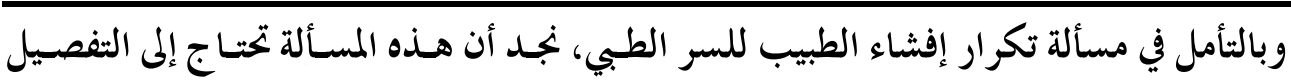
كالآتي:

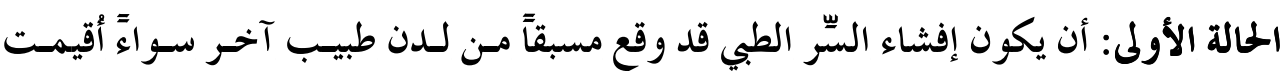

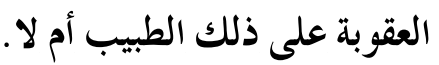

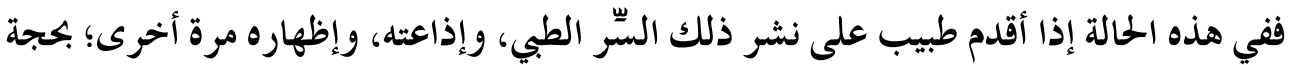

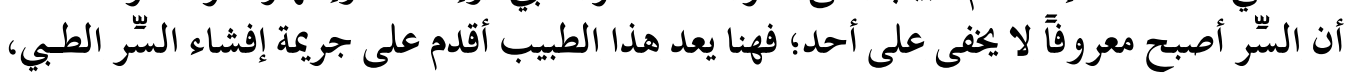
ويستحق العقوبة على ذلك.

التعليل:

1- أن إفشاء السِّر الطبي مرة لا يمنع من العقاب عليه مـرة أخـرى، فـالنكرار يزيــد مـن الإلمام

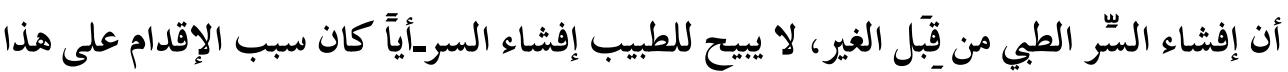

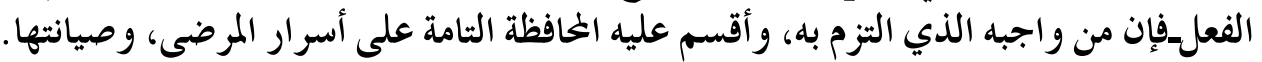

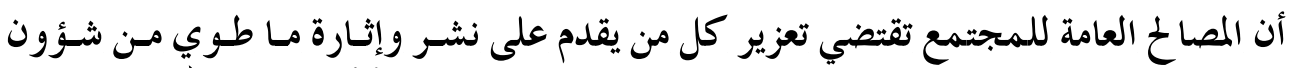

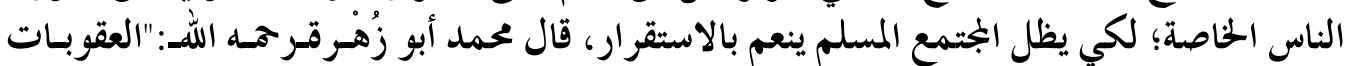

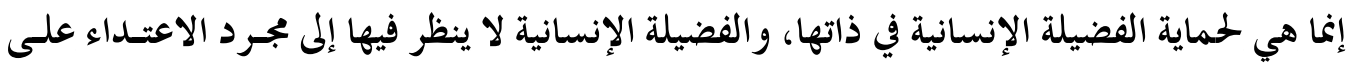

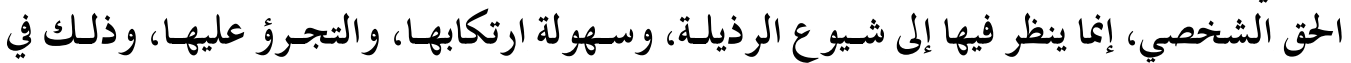

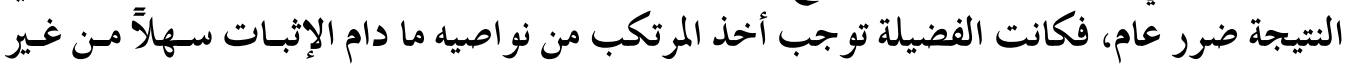

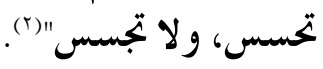

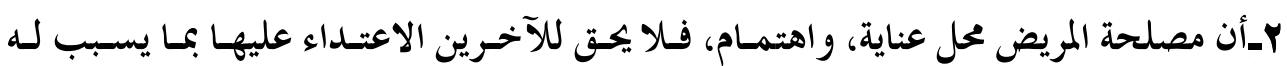
ضرراً، أو حر جاً، فالمريض يتأذى من نشر سره لمرة و احدة، فما بالك بنشره من أطر افٍ متعددة !! r- - أن إفثاء السِّر الطبي من عدة أطباء يزيده عند عموم الناس قوة، ويكسبه درجة كبيرة من اليقين، فالناس يصدقون الطبيب فيما يقول عادة، فما بالك إذا صدر من عدة أطباء !!. ولذا فالأمر يتطلب إقامة عقوبة إفشاء السِّر مهما تكرر.

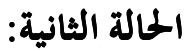

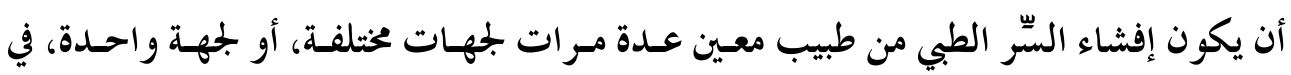
أوقات متعددة قبل إيقاع العقوبة عليه الطيه

(1) ينظر : المسؤولية الجز ائية للأطباء: موفق عبيد،، ص( · (1). 


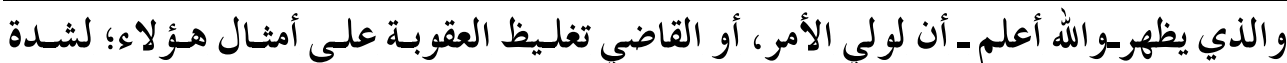

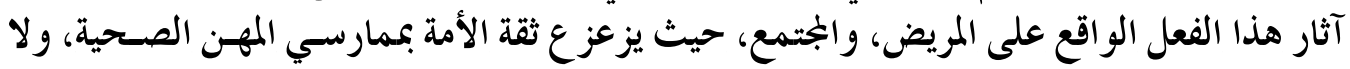

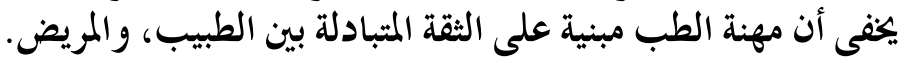

الحالة الثالثة: - الثالة

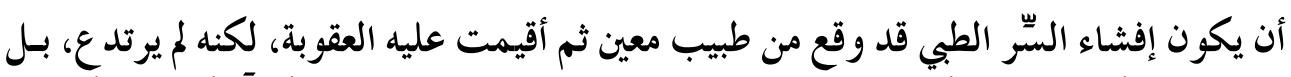

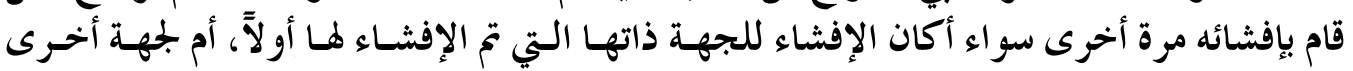
مختلفة

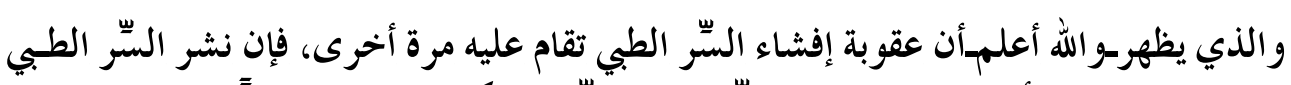

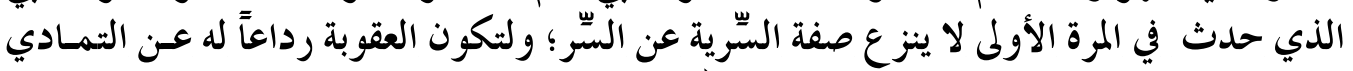

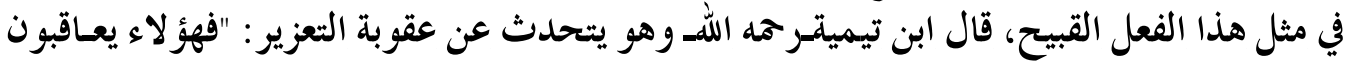

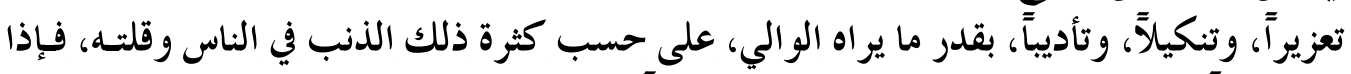

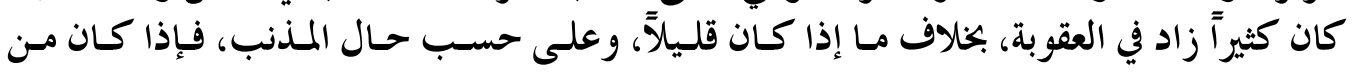

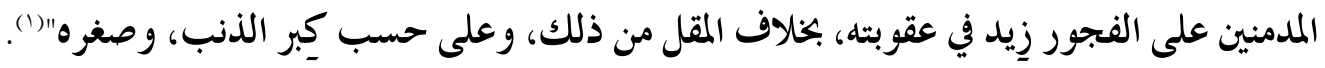

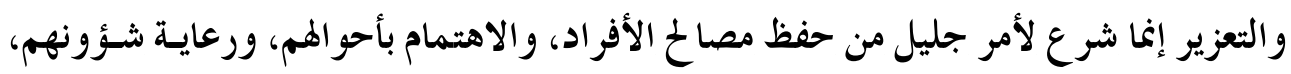

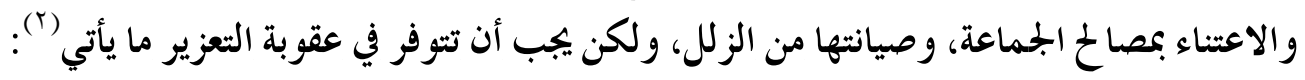

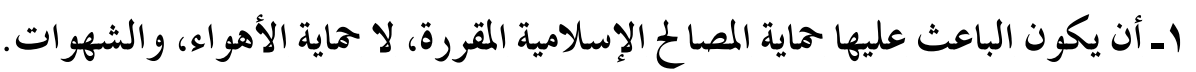

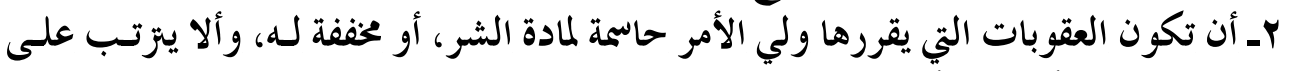

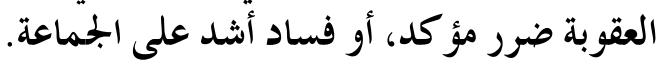

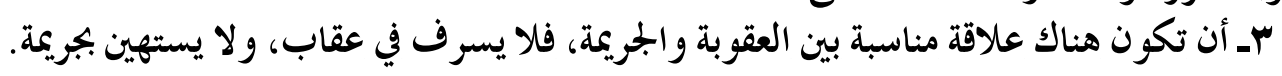
عـ المساو اة و العدالة بين جميع أفر اد الأمة. 


$$
\text { المطلب الرابع }
$$

\section{كيفية إخبار الطبيب المريض بطبيعة مرضه}

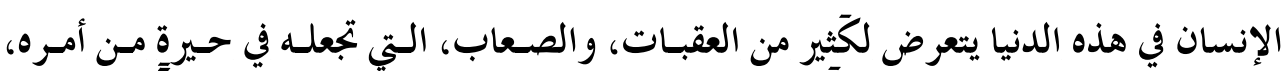

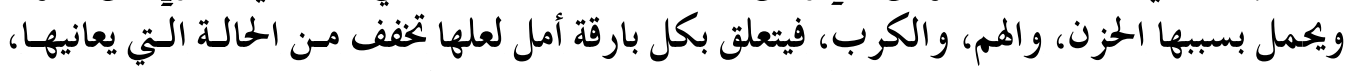

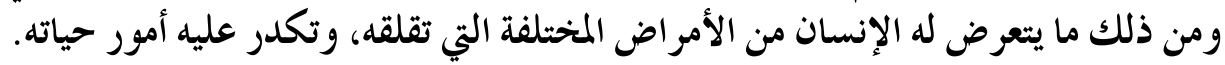

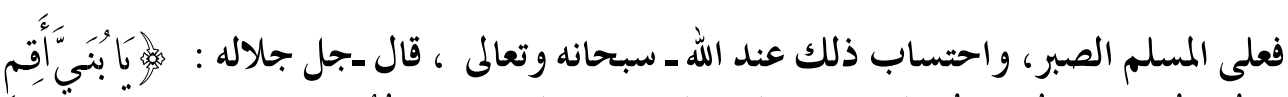

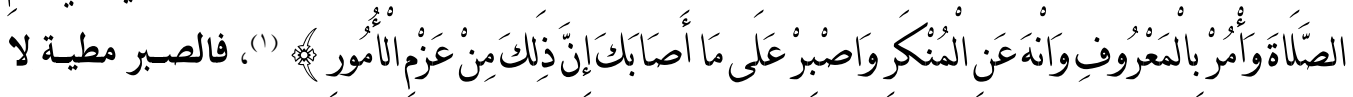

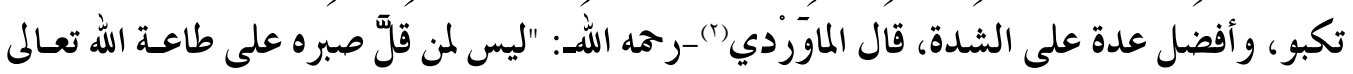

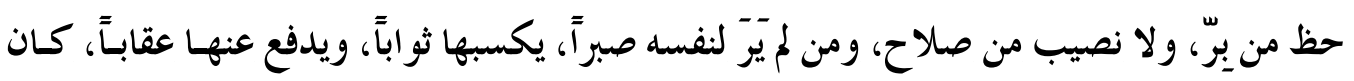

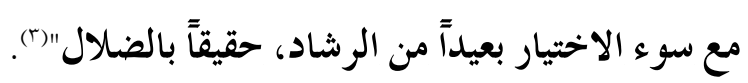

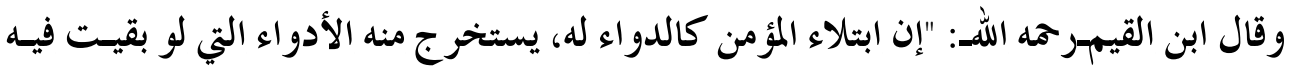

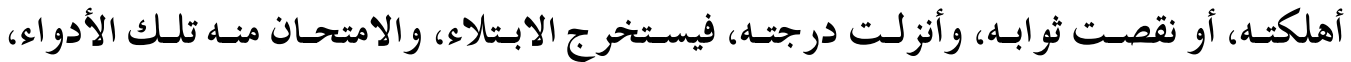

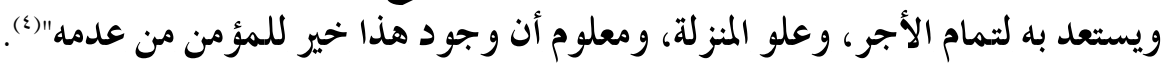

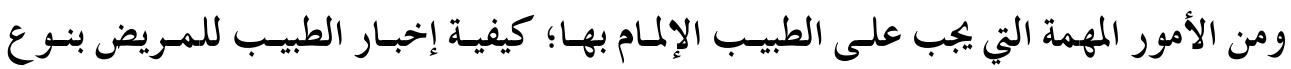

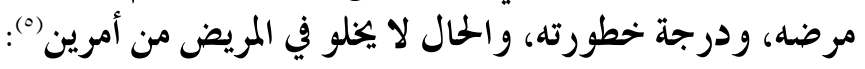
الأمر الأول: إذا كان المريض صغيرًا في السن.

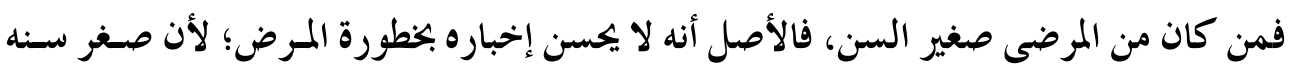

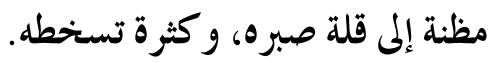

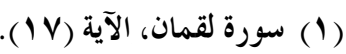

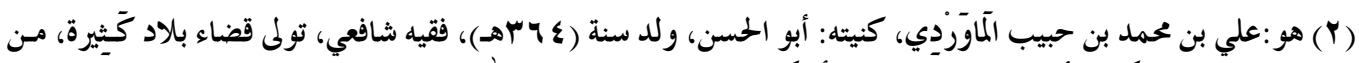

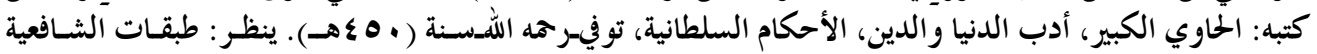

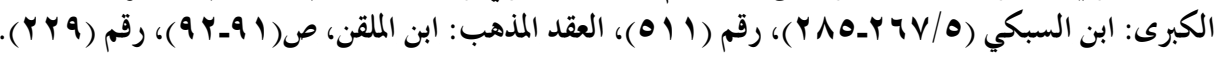

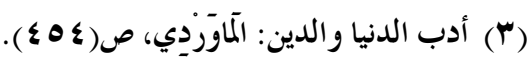

(צ) (إغاثة اللهفان من مصائد الشيطان: ابن القيم، ص(1) ه هـ).

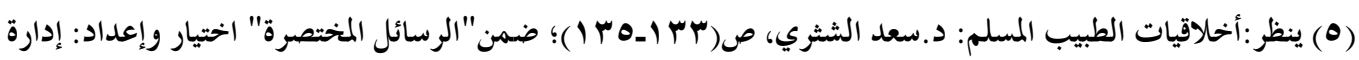

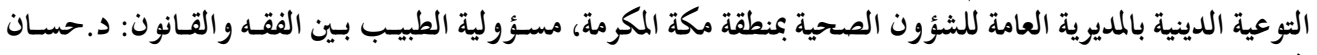


ويستثنى من ذلك وجود الفائدة من إخباره نحو ابتعاده عن التصرفات المؤذية له، و المؤثرة على

وقد سئلت اللجنة الدائمة للبحوث العلمية والإفتاء سؤالًا مفاده: "قد يحتا ج الطبيب أحياناً إلى

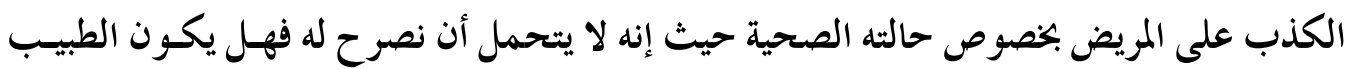
آثماً ؟".

فأجابت: "يجوز الكذب عليه إذا كان الكذب ينفعه، ولا يضره، و لا يضر غـيره، وإن أمكـن أن يستعمل الطبيب والطبيبة المعاريض دون الكذب الصريح فهو أحوط وأحسن" (1).

$$
\text { الأمر الثاني: إذا كان المريض كبيراً في السن. }
$$

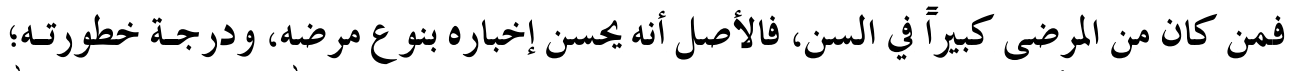

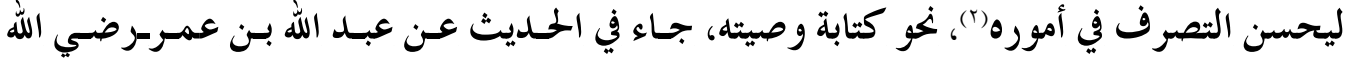

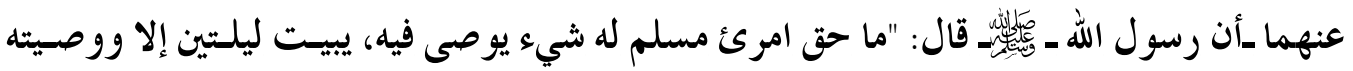

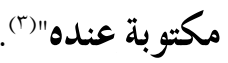

وطريقة إخبار الطبيب مريضه بنوع المرض لإ لا بد أن تكون مناسبة ومهذبة، مهما تكـن الحقـائق،

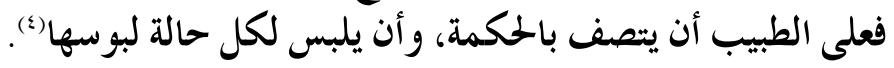
جاء في "نظام مز اولة المهن الصحية" ما نصه:

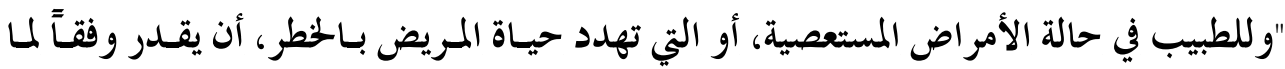

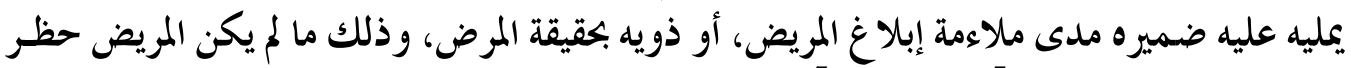

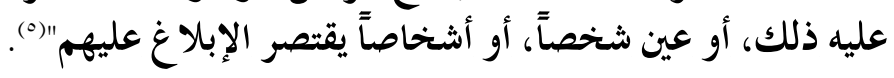

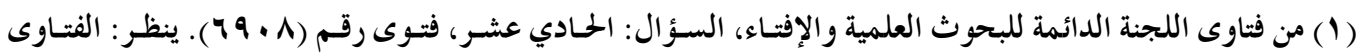

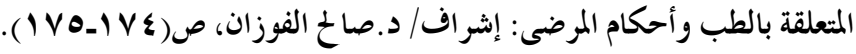

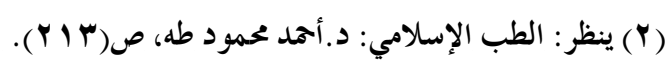

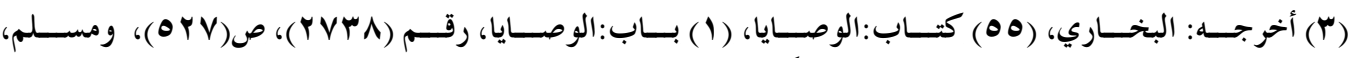

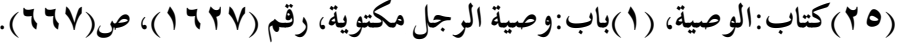

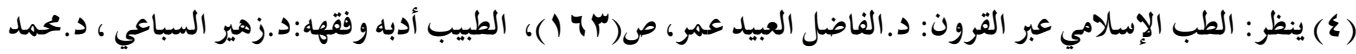

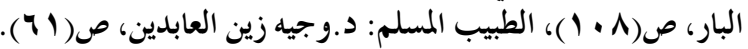

(•) ينظر : نظام مزاولة المهن الصحية، الفصل الثاني، الفرع الثاني، المادة: الثامنة عشرة، ص( • (1). 


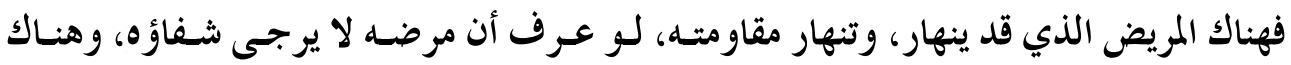

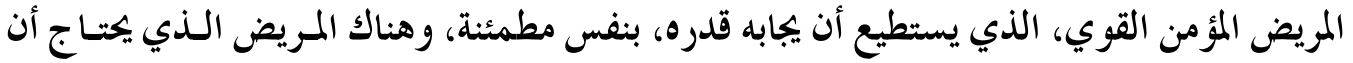

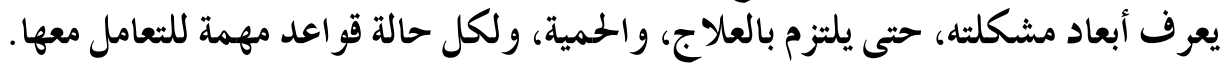
فعلى الطبيب اتخاذ أنسب الطرق لإخبار مريضه بالمشكلة التي يعاني منها، ومن ذلك ما يأتي (r):

$$
\begin{aligned}
& \text { I. التدرج في إعطائه خبر إصابته بالمرض. } \\
& \text { Y. ع عدم الجزم بحصول المرض في الإخبار الأول. } \\
& \text { r. اختيار الوقت المناسب للإخبار. }
\end{aligned}
$$

ع. أن يشرح للمريض طبيعة مرضه بأسلوب حكيم مثقن، وبعبارات مناسبة. ه. الإيعاز لشتص مناسب بإخبار المريض بذلك، ممن يكون فيه حسن تدبير. ا. التذكير بوجود بعض الحالات المماثلة التي كتب الله تعالى لها الثفاء. V. لفت نظر المريض إلى عظم أجر الصبر، والتسليم لقضاء اللهـجل جلالكـ، وقدره. 1. الإشارة إلى وجود أمر اض أصعب منه.

وبينت"الهيئة السعودية للتخصصات الطبية"ما ينبغي على الطبيب مر اعاتسه عنــ إخبـار المـريض عن طبيعة مرضه، ومن ذلك (r) :

1. عدم مفاجأة المريض بالخبر السيئ، ومراعاة التدرج، وإعداد المريض نفسياً لتقبل الحبر.

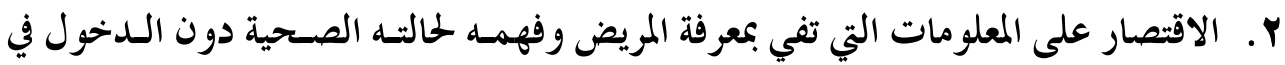

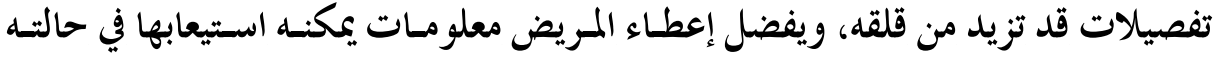
تلك. r. أختيار الوقت المناسب لإخبار المريض، ويفضل الوقـت الـذي يكـون فيـه المـريض مسـتقرً (1) ينظر : الطبيب أدبه وفقهه: د.زهير السباعي، د.محمد البار، ص(1 + (1)، مسؤولية الطبيب بين الفقه والقانون: د. حسان

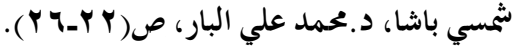

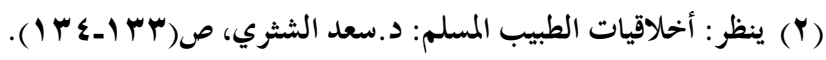

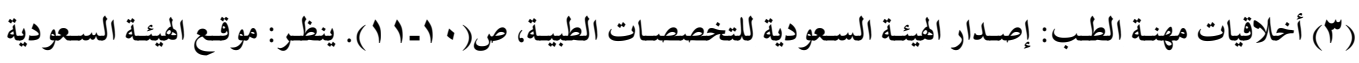
للتخصصات الطبية على شبكة الإنزنت: WWW.scfhs.orq. 


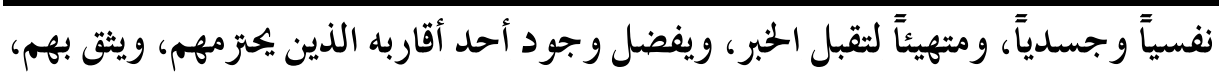

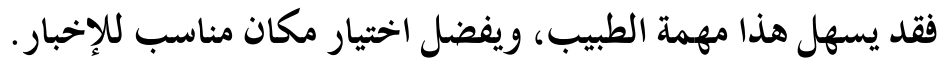

ع. إعطاء وقتٍ كافٍ للإخبار، فينقل الطبيب هذا الحبر وهو هادئ النفس، وألا يشعر المريض

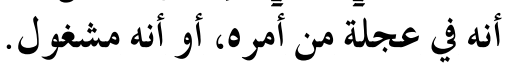

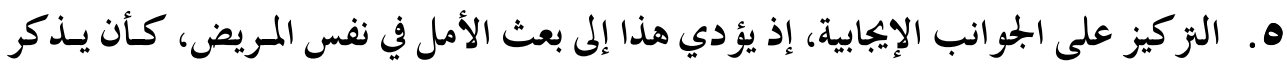

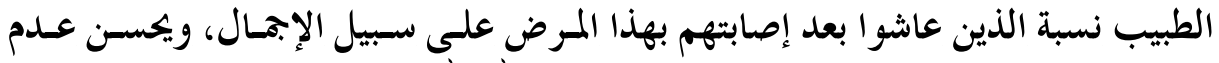

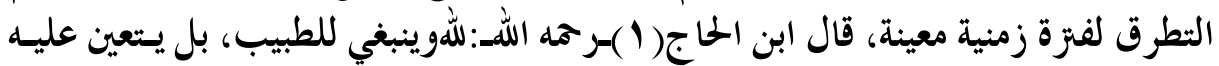

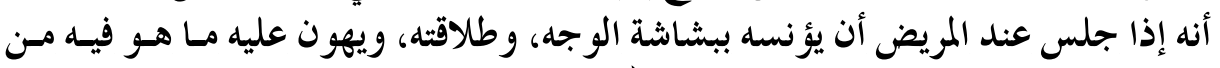

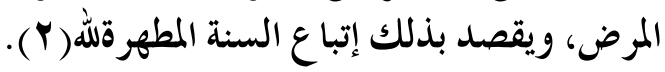

7 ـ تحففيف آلام المريض النفسية، والجسسدية قدر الإمكان؛ وعدم عزله، أو البعد عنه بما يشعره

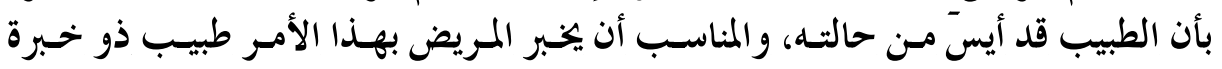

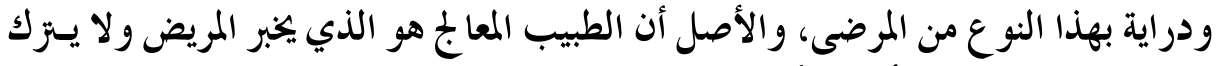

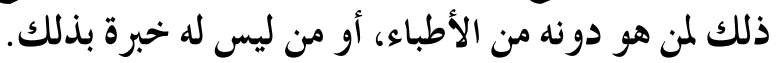

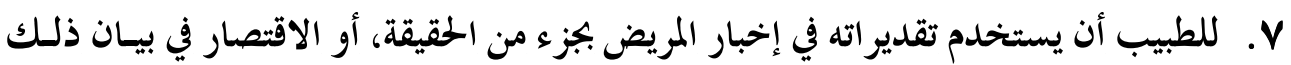

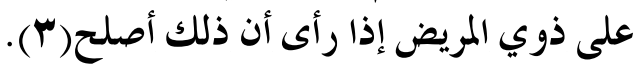

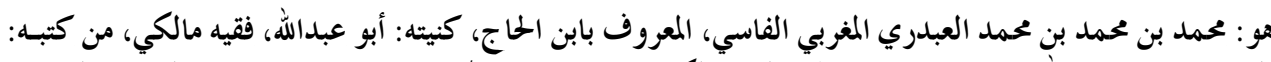

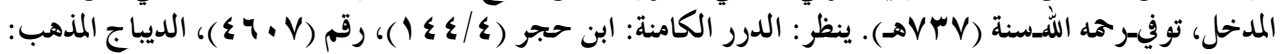

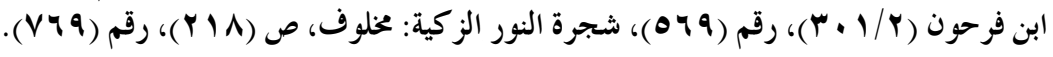

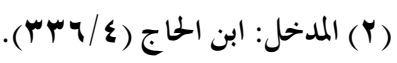

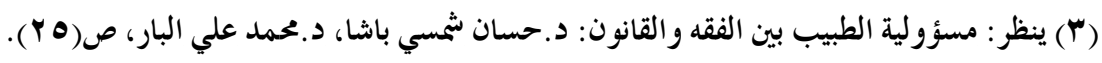
- 919 - 


\section{المبحث الثالث}

\section{حكم إفشاء أفراد الطاقم الطبي للسر الطبي}

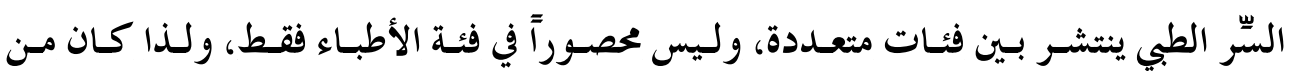

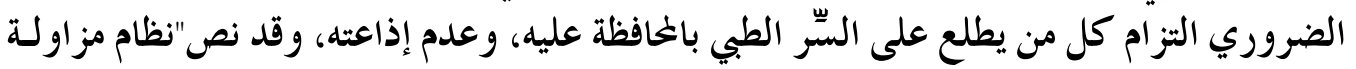

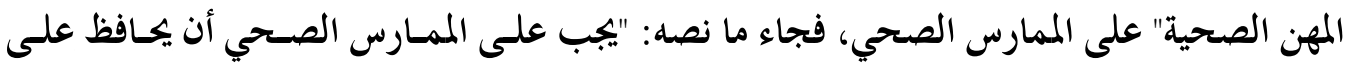
الأسرار التي علم بها عن طريق مهنته" (') .

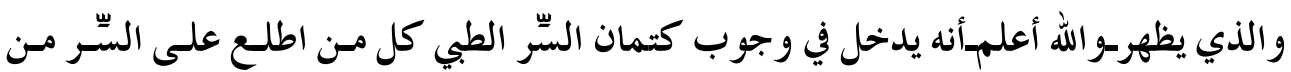

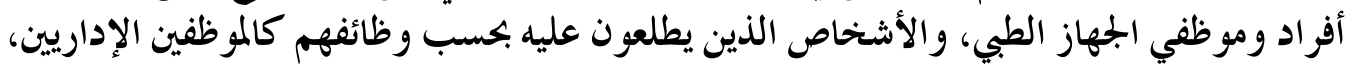

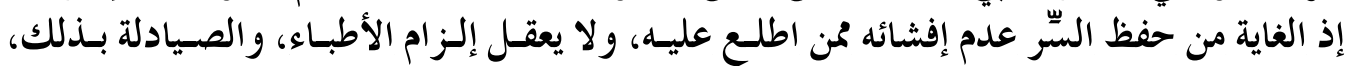
وإباحته لغيرهم (r).

وجاء في"الشعار الدولي لآداب مهنة التمريض"ما نصسه: "على الممرضسة أن تحستزم وتحستفظ بأيسة

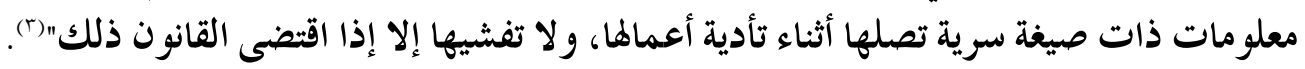

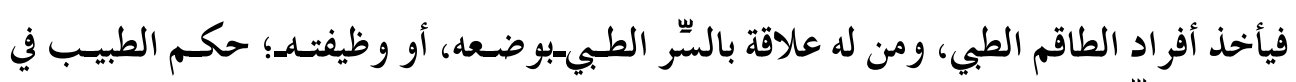

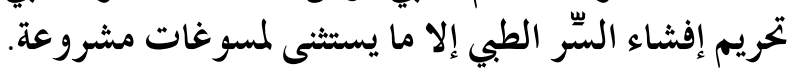

$$
\begin{aligned}
& \text { ويمكن تعليل ذلك بما يلي: }
\end{aligned}
$$

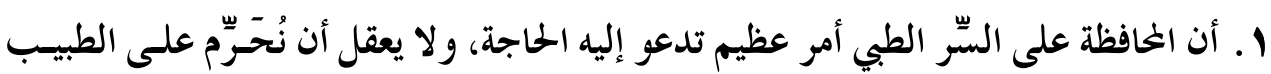

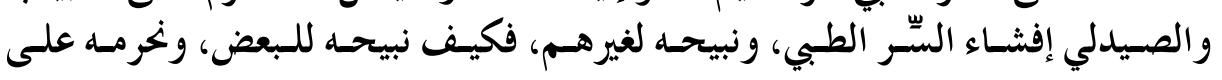

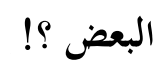

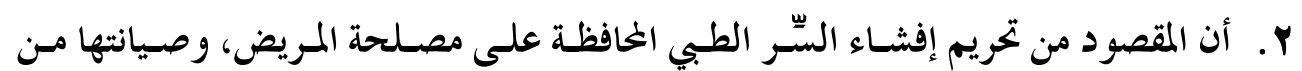

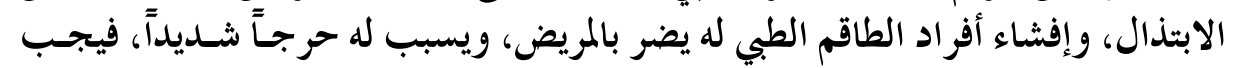
رفعه عنه، وإز الته.

(1) نظام مزاولة المهن الصحية: الفصل الثاني، الفرع الثاني، المادة الحادية والعشرون، ص(IV).

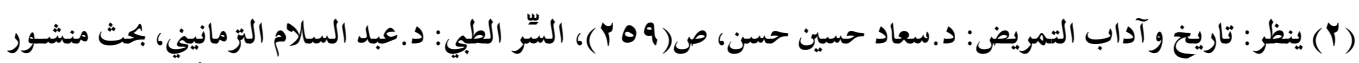

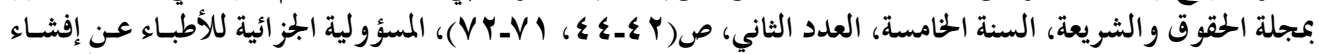

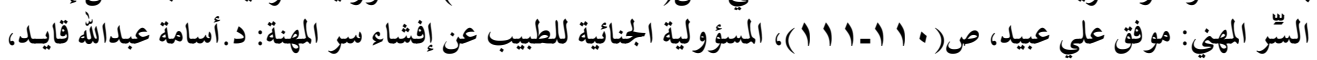

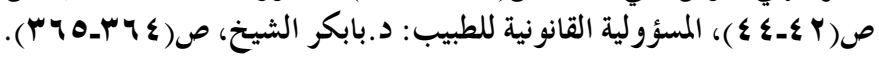

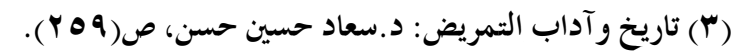


r. أن تخصيص حفظ السِّر بالأطباء والصيادلة لا يعني إعفاء غيرهـم مـن الالتـز ام بحفظظ السِّر

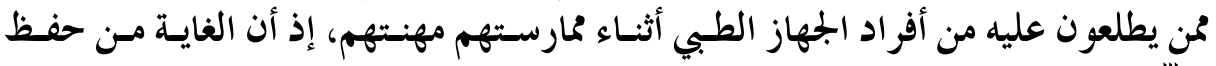

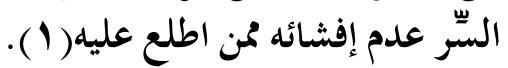

ع. أن عدم إلزام الطاقم الطبي بكتمان السِّر الطبي يجعـل الأنظمـة الصـادرة بـإلز ام الطبيـب والصيدلي بكتمان السِّر عديمة الفائدة.

(1) ينظر : السّر الطبي: د.عبد السلام التزمانيني ،بحث منشسور بمجلـة الحقوق والشـريعة، السـنة الخامسـة، العـدد الثاني، - 9r) - 
المبحث الرابع

(التقارير والوصفات الطبية)

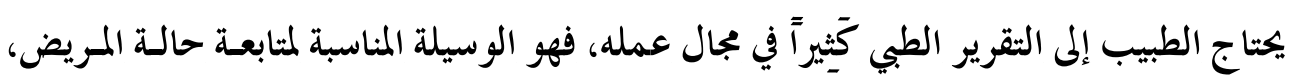

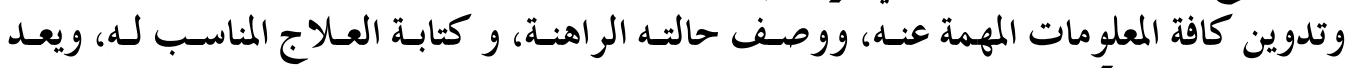

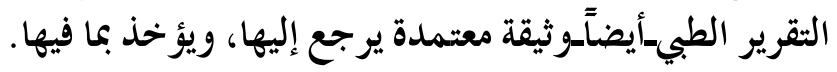

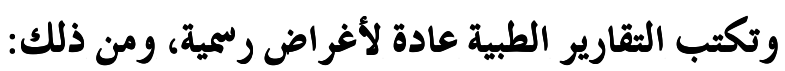

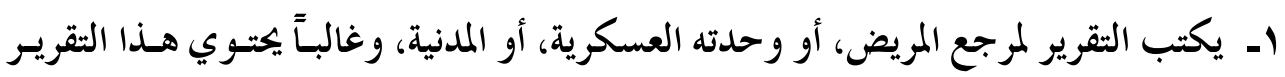

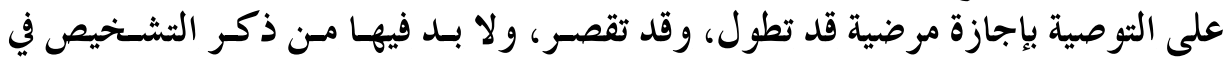

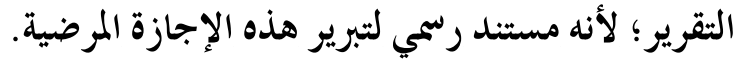

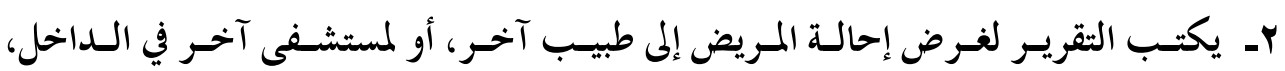

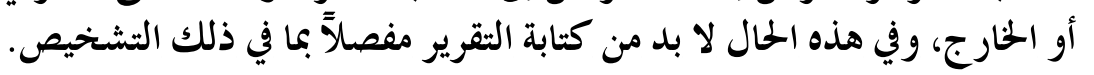

بـــ يكتب التقرير بناءً لطلبات معينة_كالضمان الاجتماعي-، وفي هذه الحال يطلب التشخيص مفصلاً. * تعريف الثقرير الطبي: هـو : "مـا يحـرره الطبيـب بعـد دراسـته لحسال المـريض دراسـة وافيسة،

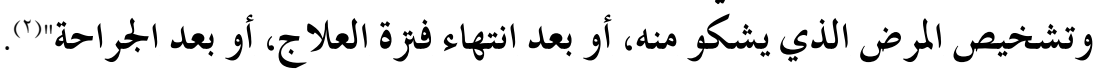
* محتوى التقرير الطي: يشتمل التقرير الطبي عادةً على أمور مهمة هي (r): أ. وصف شكوى المريض. ب. الأعر اض، و العلامات التي تظهر على المريض. ج. نتائج الفحوص السِّريرية، والمخبرية، ونحوها.

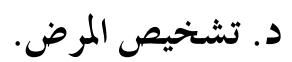
هـ. العلاج المناسب للمريض، ومدى استجابته له.

(1) ينظر نماذج من التقارير والوصفات الطبية في ملحق البحث. (Y) الموسوعة الطبية الفقهية: د.أحمد محمد كنعان، ص( ( ) (Y). 


$$
\begin{aligned}
& \text { و. حال المريض الصحية عند كتابة الثقرير الطبي. } \\
& \text { ز. التوصيات ببرنامج علاجي محدد إذا تطلب الأمر. } \\
& \text { ح. تحديد برنامج ومواعيد المتابعة المستقبلية للمريض إذا لزم الأمر. }
\end{aligned}
$$

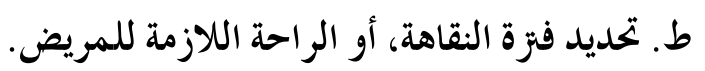

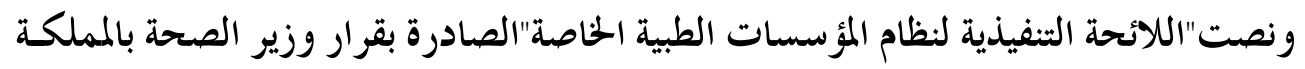

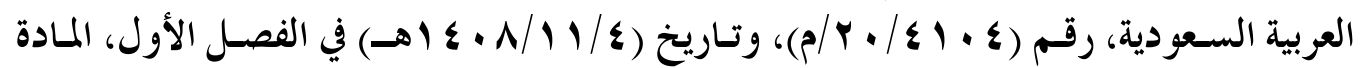

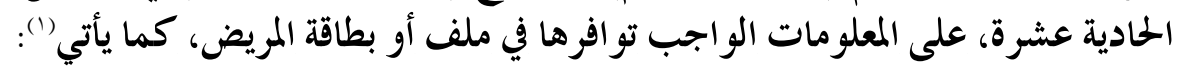
اـ البيانات الشخصية: "السمه الثلاثي، وسنه، وجنسه، وجنسيته"، ورقمم التسـجيل في سـجل

$$
\text { المرضى، وتاريخ كل زيارة. }
$$

ץـ الأعر اض المرضية، و الفحص السِّريري، و الفحوص المخبرية، و الثعاعية.

$$
\begin{aligned}
& \text { بـ التشخيص، والعلاج الموصوف في كل زيارة. } \\
& \text { عـ تطور الحال الصحية. }
\end{aligned}
$$

وبالنسبة لاستمارة الإحالة أو التقرير الطبي، فيجب أن يتضمن المعلومات الآتية(؟):

$$
\begin{aligned}
& \text { ا ـ اسم المريض، وسنه، و جنسه، و جنسيته. } \\
& \text { Yـ تشخيص المرض، وعلاجه. } \\
& \text { rـ تطور الحال و المضاعفات. }
\end{aligned}
$$

$$
\begin{aligned}
& \text { ع- عنوان جهة الإحالة، والغرض المنشود من إحالة المريض، و التوصيات. } \\
& \text { هـ الحتم الرسمي للمؤسسة، وتوقيع الطبيب المسؤول. }
\end{aligned}
$$

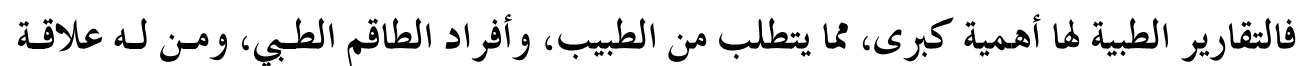

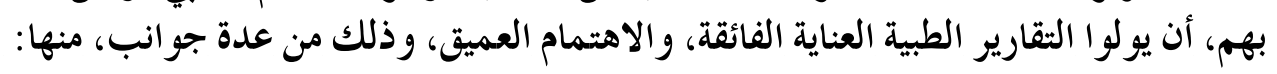

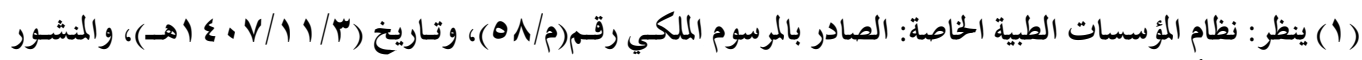

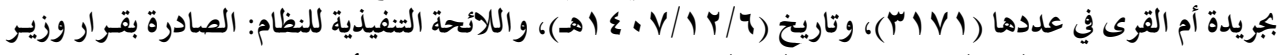

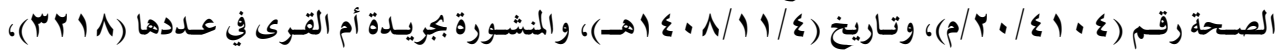

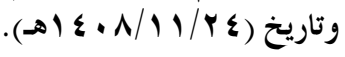




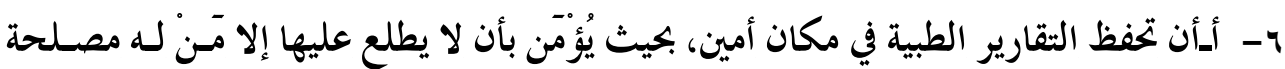

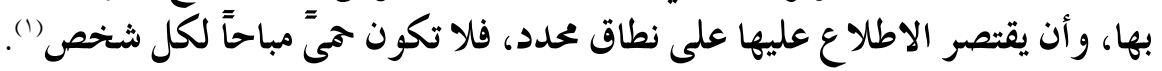

ب-أن يحرص الطبيب على التدوين الدقيق_بكل أمانقـللمعلومات الواردة في الثقرير الطبي، وأن

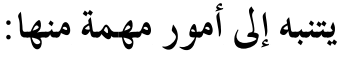

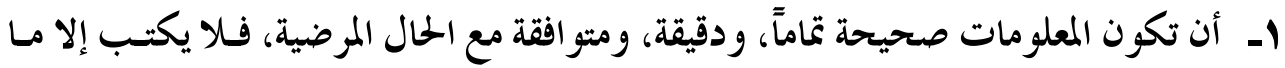

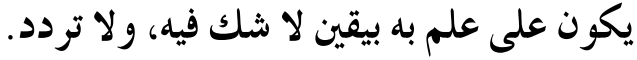

r. ـ أن لا يدوّن إلا ما تدعو الحاجة إليه، وأن ينزّه التقريـر الطبي مـن المعلومـات الـتي لا طائسل

منها.

بـ على الطبيب ترك تسجيل ما لا علاقة له بالمرض.

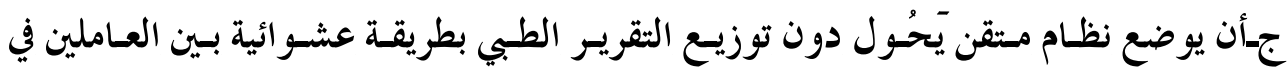

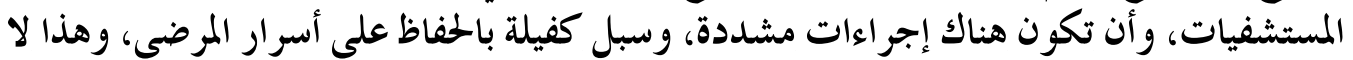

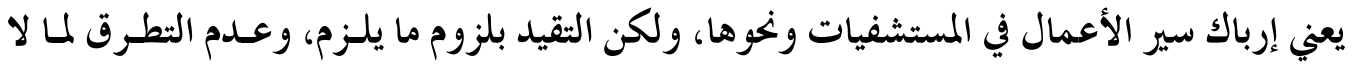

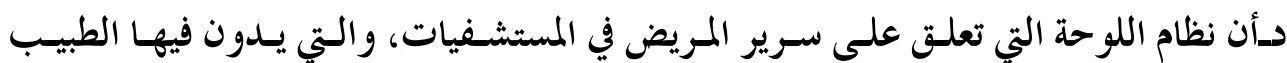

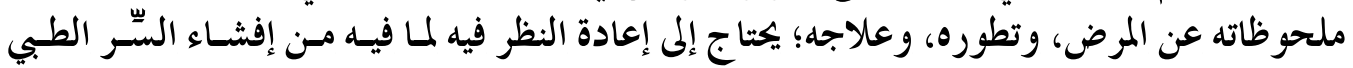

\section{* حكم إفشاء السِّر في التقارير الطبية) (s):}

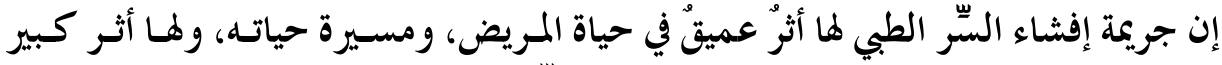

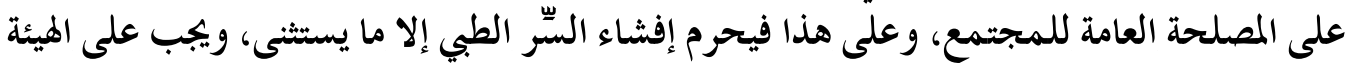

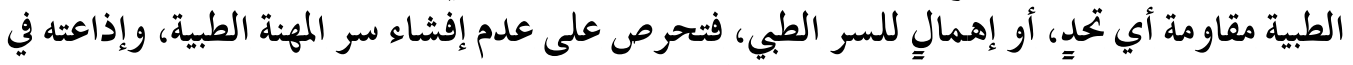

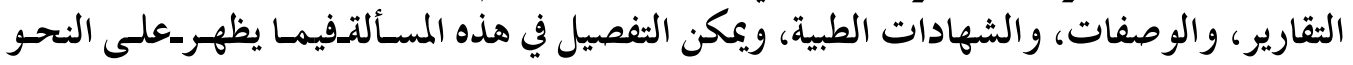

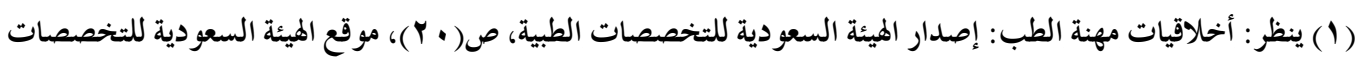

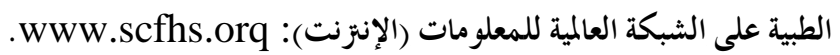

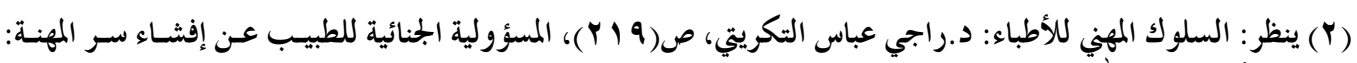

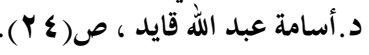

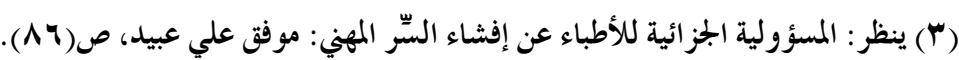

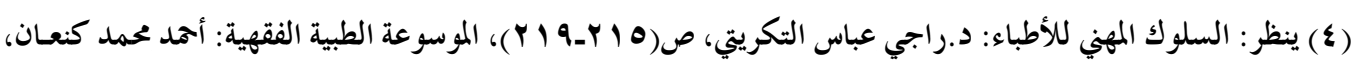




\section{إن صيغ التقارير الطبية على قسمين:}

\section{* القِسَّم الأول: التقارير الطبية الحالية من ذكر التشخيص الطبي.}

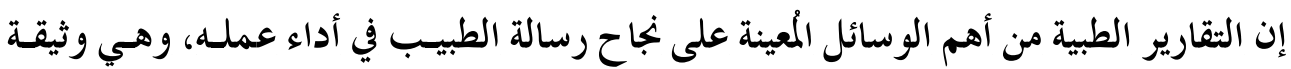

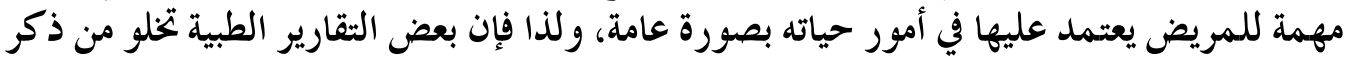

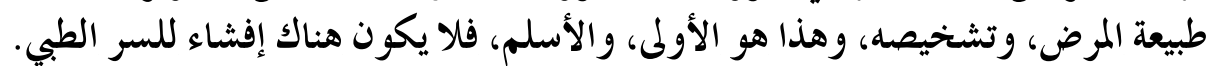

$$
\text { مع التنبيه على أمرين: }
$$

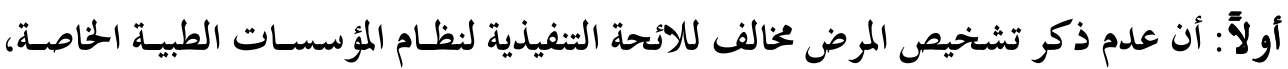

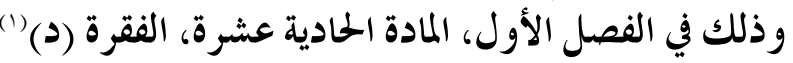

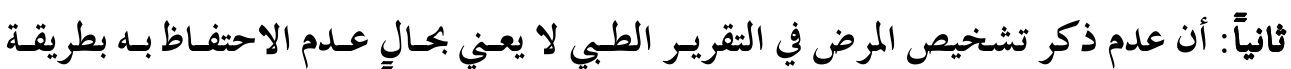

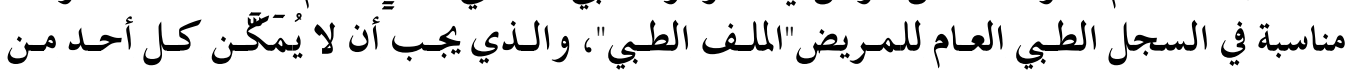

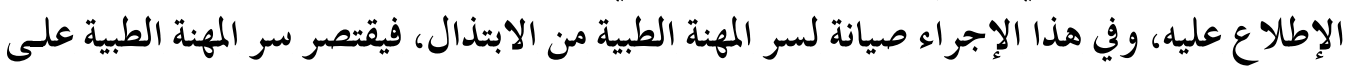
نطاق محدود، هم أحساب الاختصاص في فنط.

\section{* القِستم الثاني: التقارير الطبية التي يذكر فيها تشخيص المرض صراحة.}

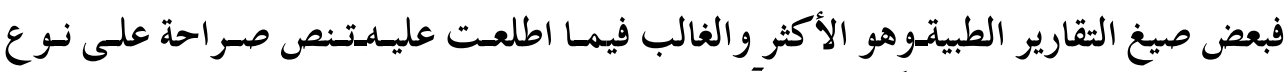

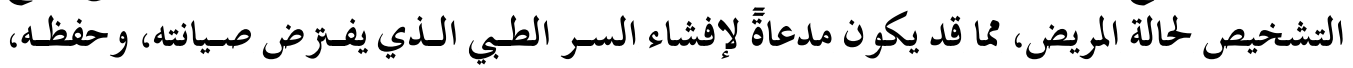
ويحرم إفشاؤه، ونشره، وإذاعته.

$$
\text { ومما ينبغي التنبيه عليه ما يأتي: }
$$

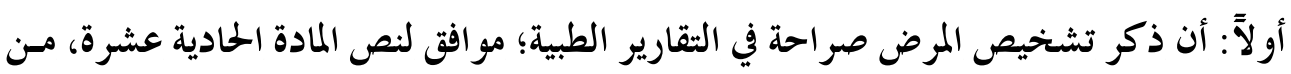

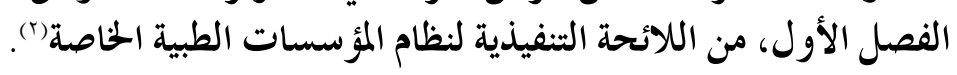

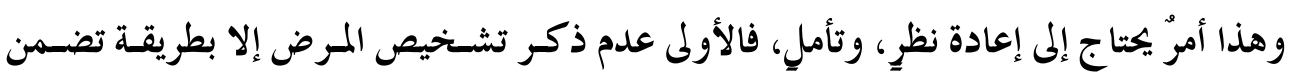

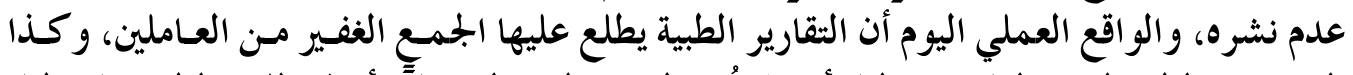

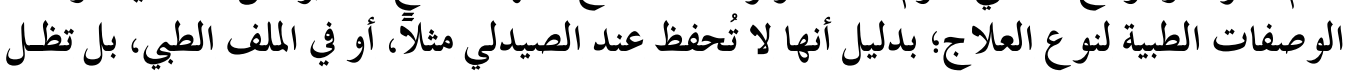




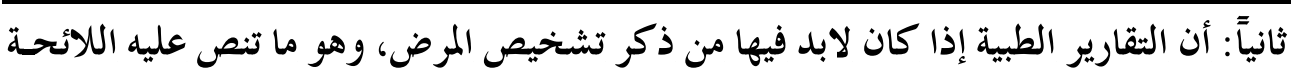

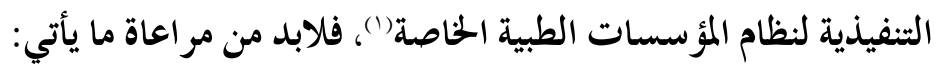

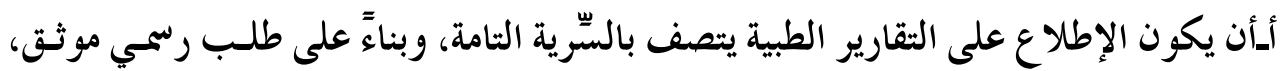

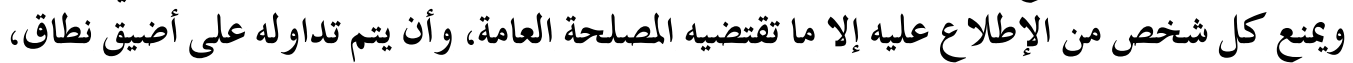

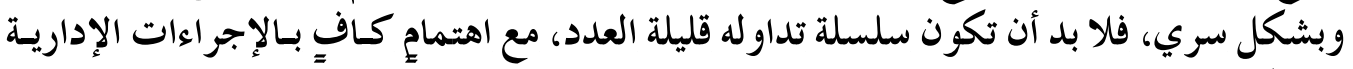
التي تكفل حفظه، وصيانته.

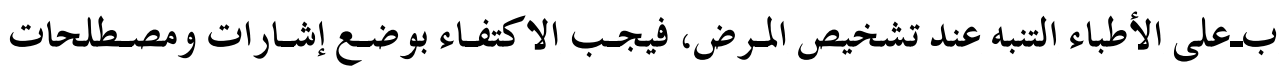

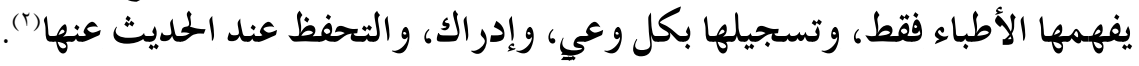

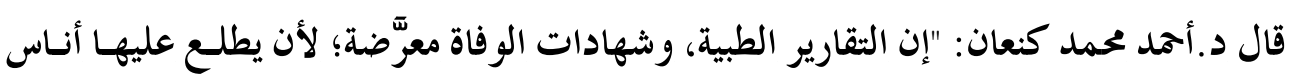

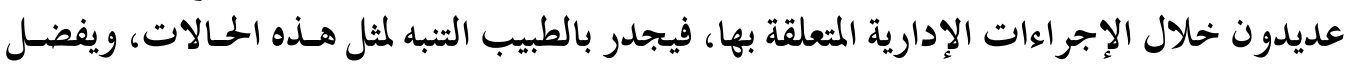

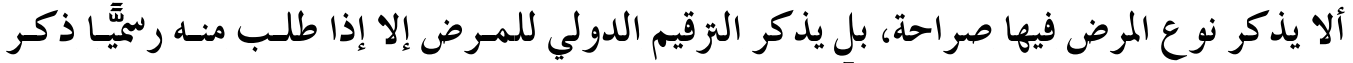

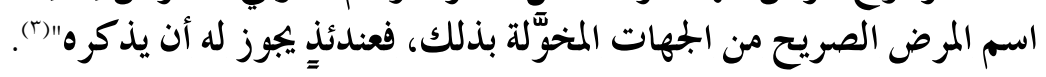

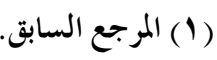

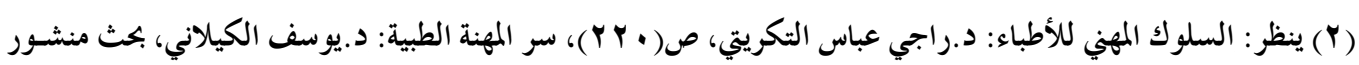

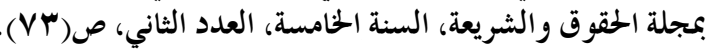

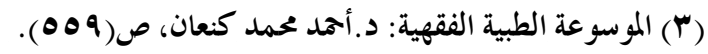


المبحث الحُامس

$$
\text { نغاذ ج لقضايا السر الطبي }
$$

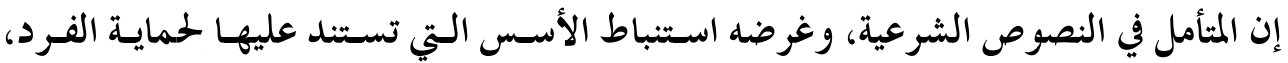

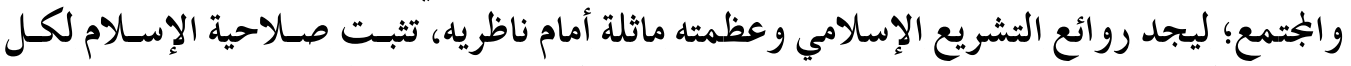

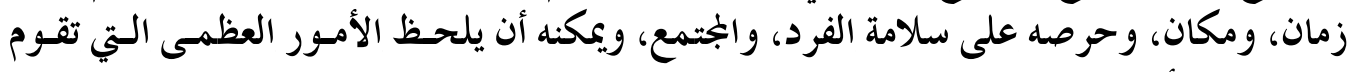
عليها هذه الأسس، ومان، وحر وهل علئ

الأمـر الأول: الخافظـة على الكليـات الشـرعية الحخمس، وهـي (الـدين، والـنفس، والعقلـ،

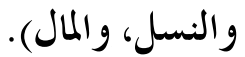

الأمر الثاني: الخافظة على مقاصد التشريع العامة التي لابــد منهـا لاسـتقرار الجُتمـع، فالخافظـة عليها مسؤولية عظيمـة، ومهمـة جليلـة، تقـع على عـاتق المسـلمين، فالأمانـة كسبيرة حسين تحملـها

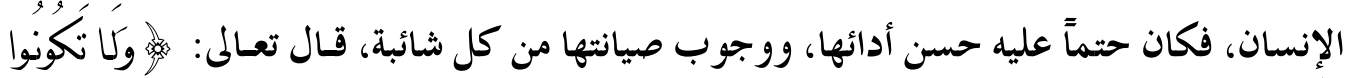

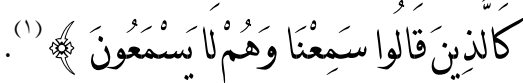

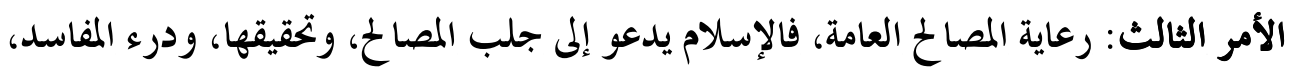

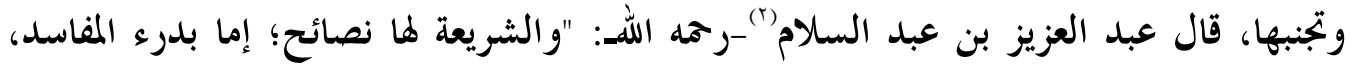

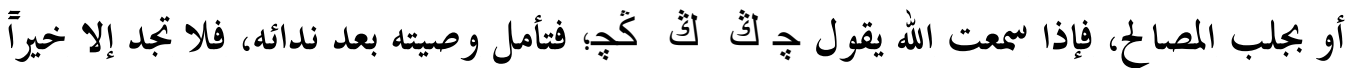

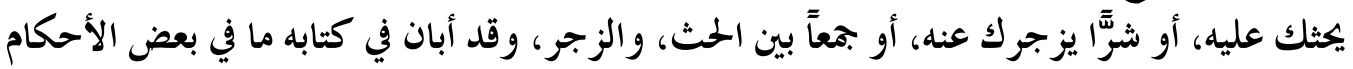

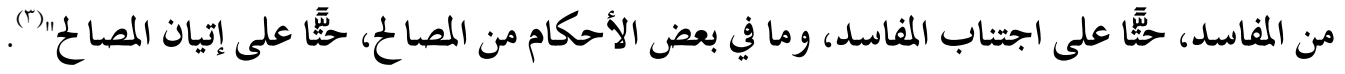

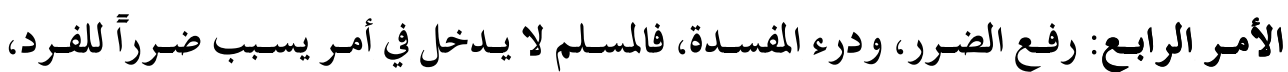
أو الأمة.

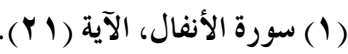

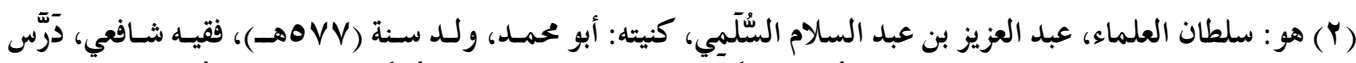

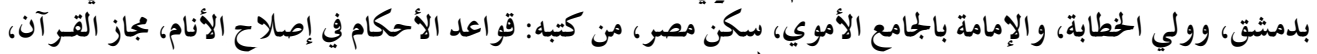

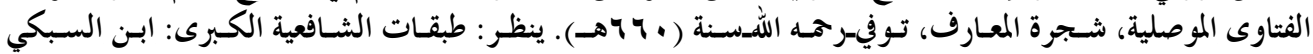

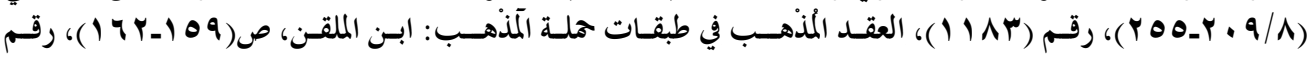


الأمر الخامس: غرس المسؤولية في نفوس الناشئة، فالإنسان مسؤول عما يصدر منه، قال تعالى:

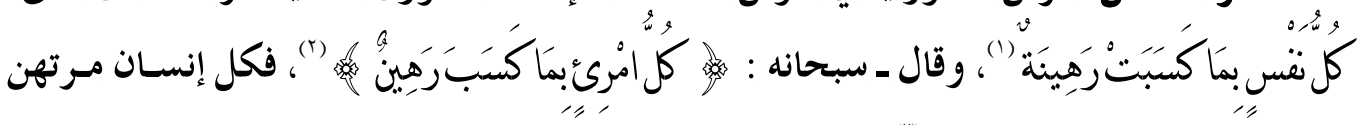
بعمله لا يؤ اخذ أحد بذنب أحد (r).

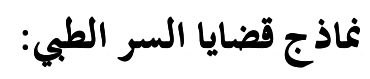

النموذج الأول: إذا كان الزوج عقيماً، واكتشفت الطبية أن زوجته حاملاً (s).

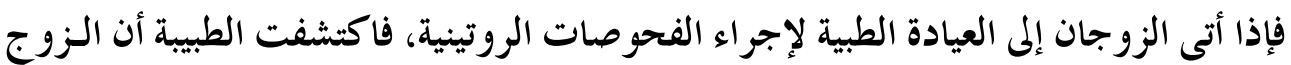

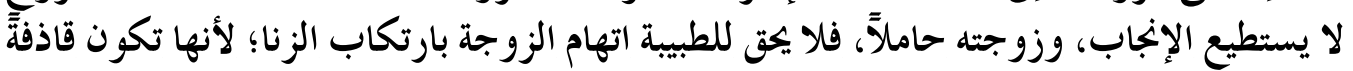

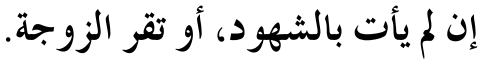

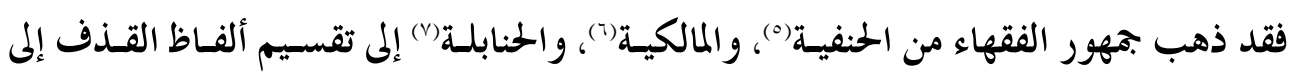
قسمين:

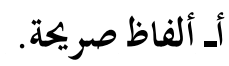

بـ ألفاظ الكناية.

وذهب الثافعية(^) إلى أن ألفاظ القذف تنقسم إلى ثلاثة أقسام هي:

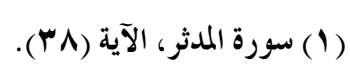

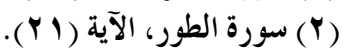

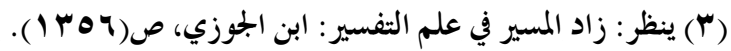

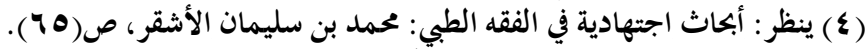

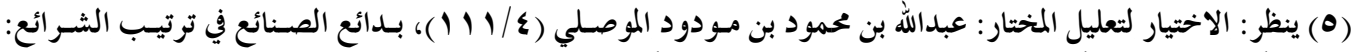

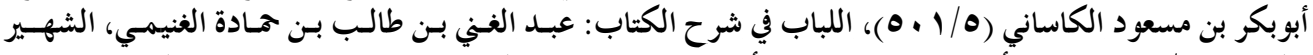

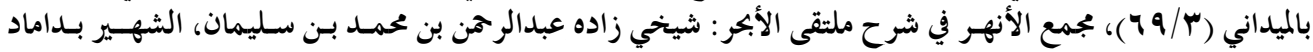

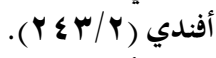

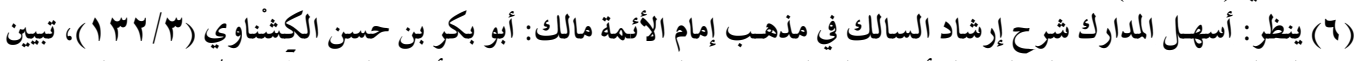

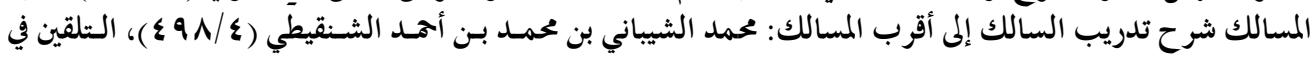

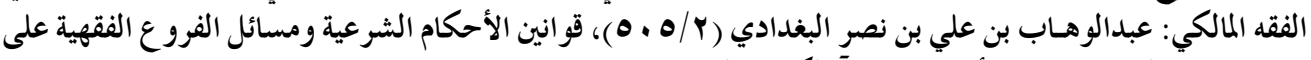

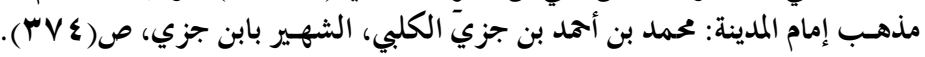

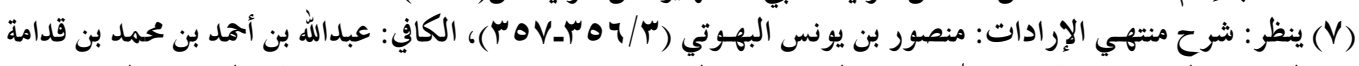

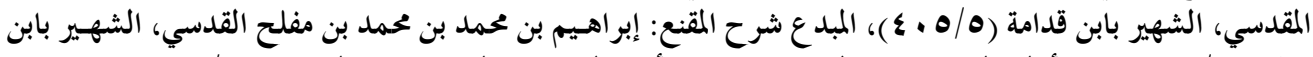

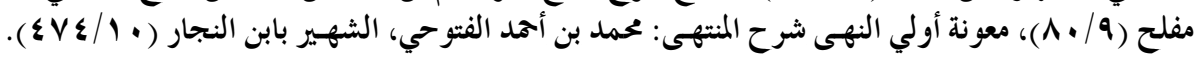

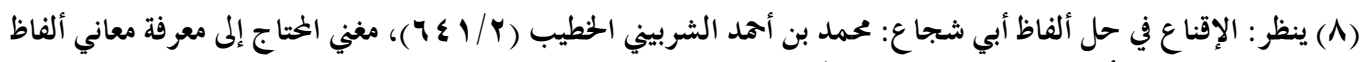

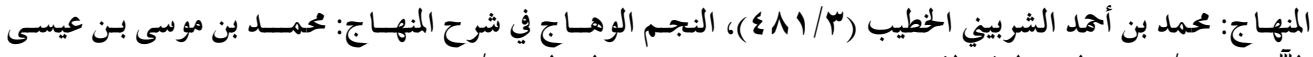

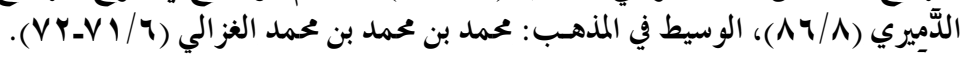


أـ ألفاظ صريحة.

بـ ألفاظ الكناية.

ج- التعريض بالقذف.

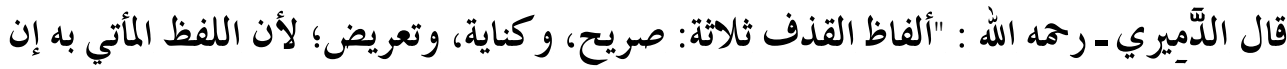

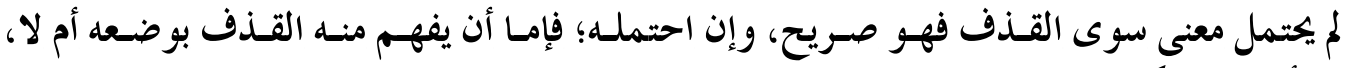

$$
\text { والأول هو الكناية، والثاني التعريض" (1). }
$$

و اهتم الفقهاء بألفاظ القذف؛ لأنها ألفاظ يتزتب عليها حكم شرعي (r).

وفي مثل هذه الحالة:

تكتني الطبيبة بوصف الحالة الطبية للزوج، نحو قولها للزوج: (تبين مـن الفحص أنـك عقيم لا

تنجب).

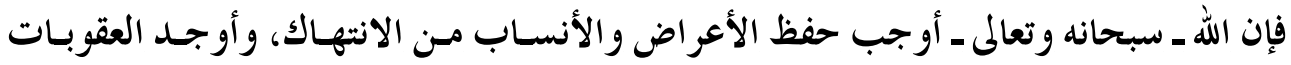

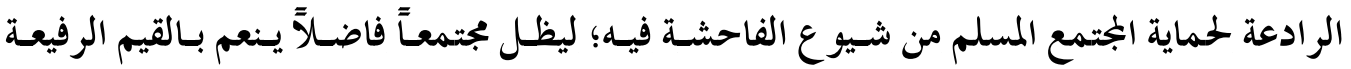

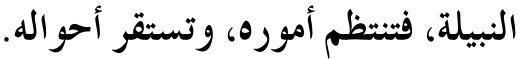

فحذر اللهـجل وعلا_من خطورة الاستخدام البـذيء للكلمـة في الإضـرار بـالغير، وأوضـح-عـز

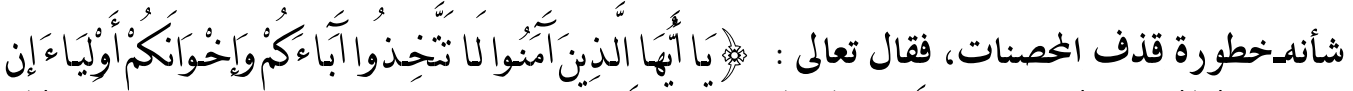

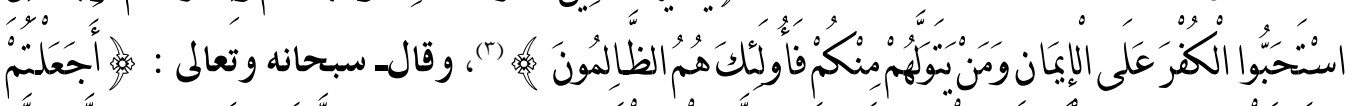

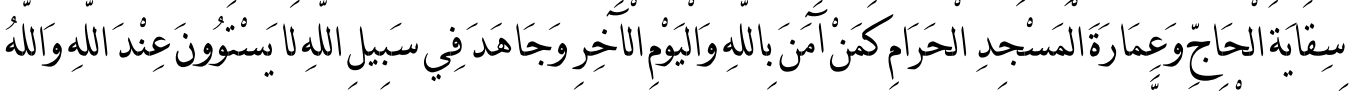

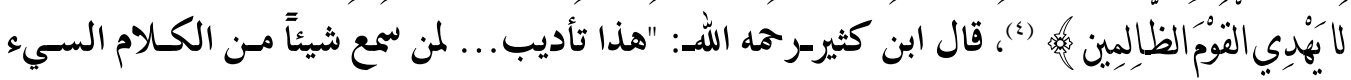
فقام بذهنه شيء منه، وتكلم بله، فلا يكثر منه، ولا يشيعه ويذيعه"(•).

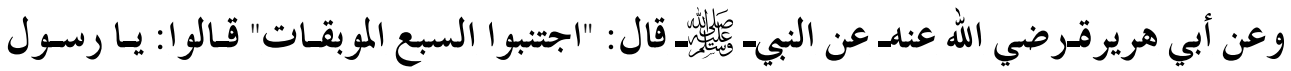

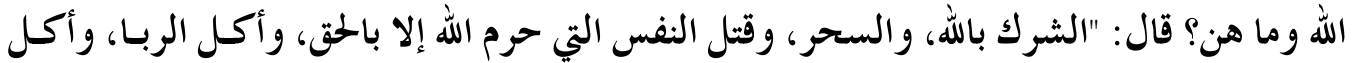

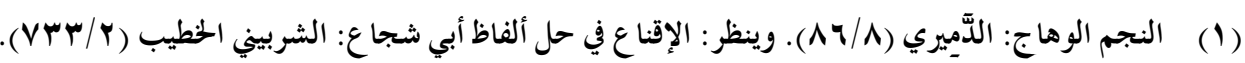

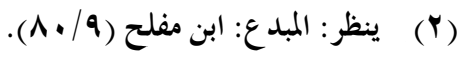

$$
\begin{aligned}
& \text { (ب) سورة النور، الآية (بآ). } \\
& \text { سورة النور، الآية (9 (1). } \\
& \text { تفسير القر آن العظيم: ابن كثير، ص(V) - (I). }
\end{aligned}
$$


مال اليتيم، والتولي يوم الزحف، وقذف الخصنات الغافلات المؤمنات" (').

النموذج الثاني: إذا كان أحد الزوجين مصاباً بمرض جنسي معد.

تعد الأمر اض المعدية من أهم الأمـر اض المرتبطـة بسـرية المعلومـات الحخاصـة بـالمريض للأسـباب

$$
\text { () ارتباط بعض الأمر اض المعدية بالوصم الاجتماعي. }
$$

Y أهمية تشخيص وعلاج الحالات لمنع انتشار العدوى إلى آخرين.

r) دور التبليغ الوبائي عن الحالات في حماية الجتمع.

ع) ارتباط العديد من الأمراض المعدية بطرق العدوى المتعلقة بالممارسات الجنسية.

•) أهمية الاستقصاء الوبائي، وتحري الحالات الكامنة قبل استفحالها حتى يتم علاجها باكراً.

$$
\text { وفي مثل هذه الحالة إذا اكتشف الطبيب إصابة المريض بمرض معد: }
$$

فعلى الطبيب مراعاة الأنظمة المرعية، وقد نص نظام (مزاولة المهن الصححية) في المـادة (الحاديـة

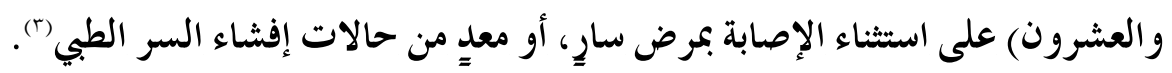

فإذا كان أحد الزوجين مصاباً بمـرض جنسـي معـدِ ينتقـل بالمباشـرة؛ فإنـه يجـبـ إبـلاغ الطـرف

وجاء في قرار مجمع الفقه الإسلامي الدولي بخصوص المصاب بمرض الإيدز ما نصه:

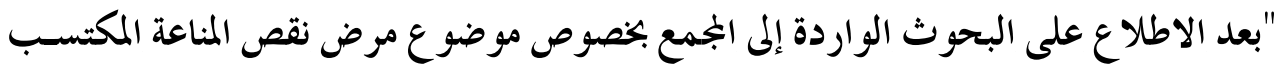

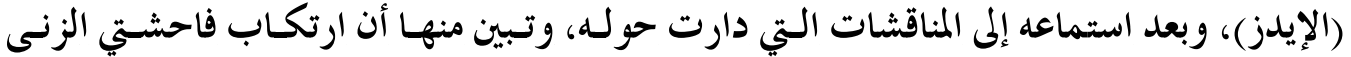

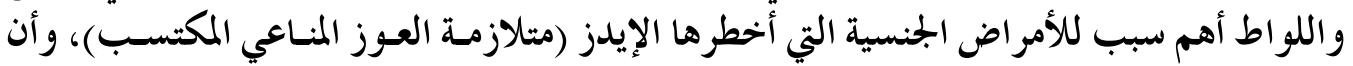

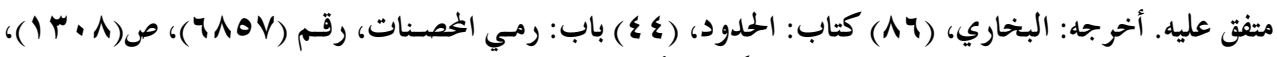

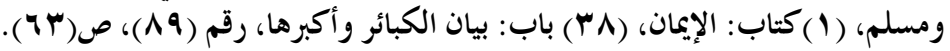

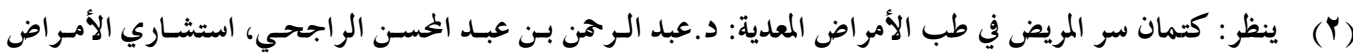

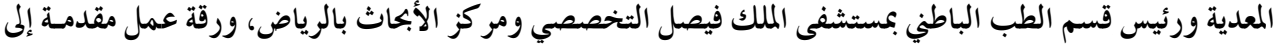

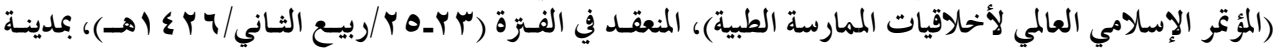




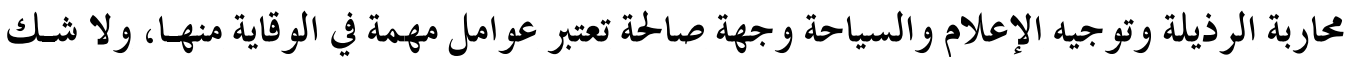

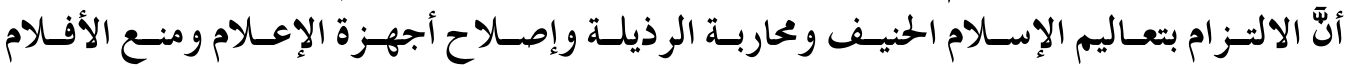

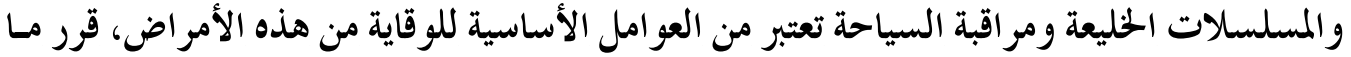

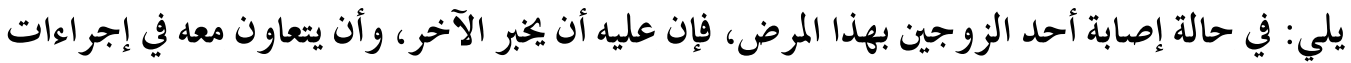

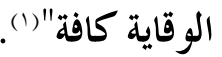

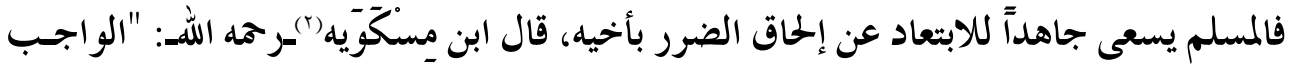

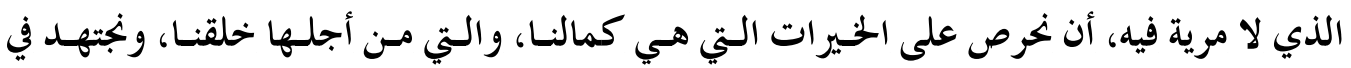

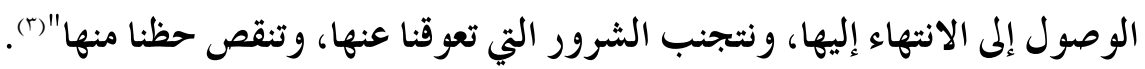

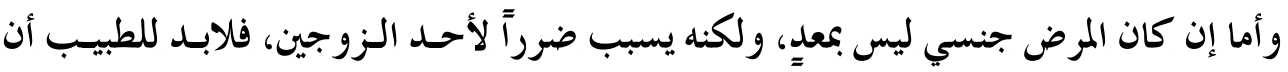

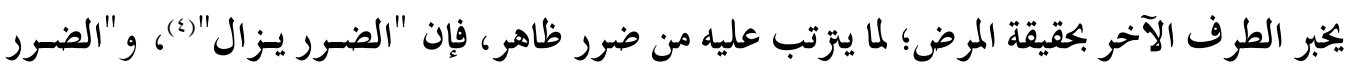

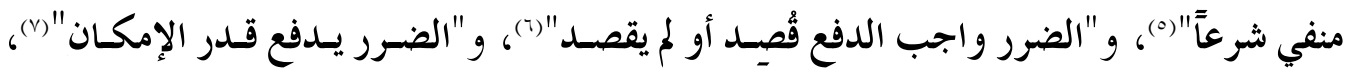
و "دفع الضرر عن المسلمين واجب" (ᄉ).

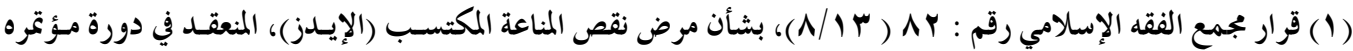

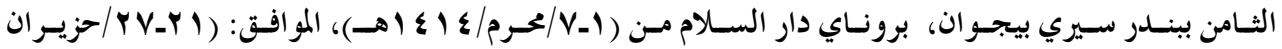

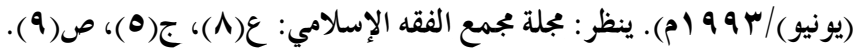

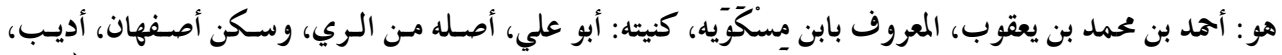

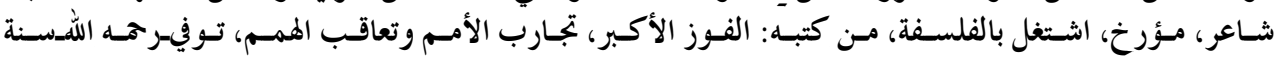

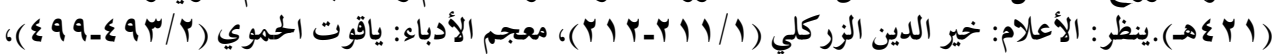

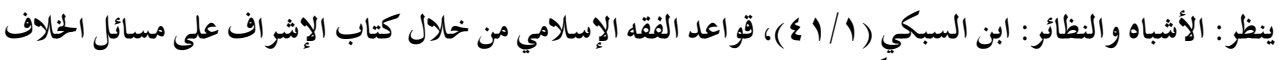

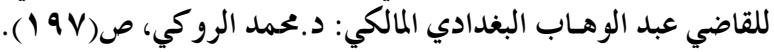

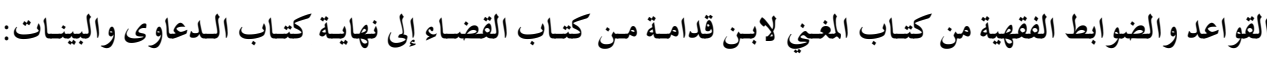

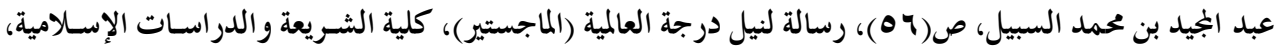

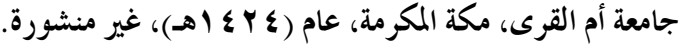

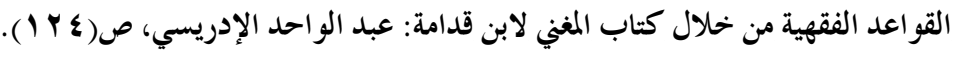

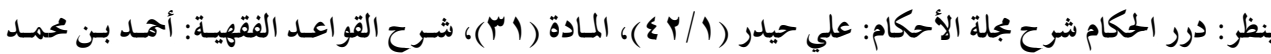

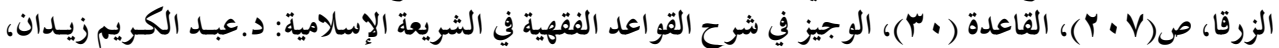

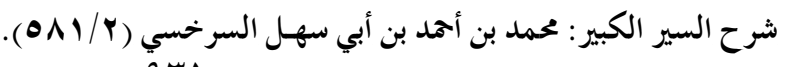


فالضابط في ذلك:

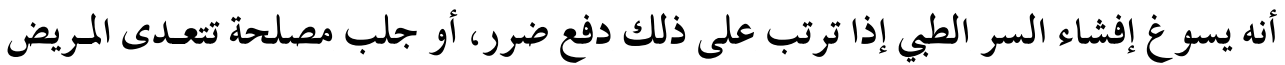

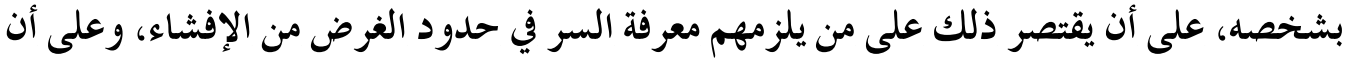

$$
\text { لا يستخدم في غير ذلك الغرض (1). }
$$

وقد أوردت الهيئة السعودية للتخصصات الصحية توصيات مهمة فيما يخص الأمر اض المعديـة،

يجب على الطبيب إتباعها، وهي (r):

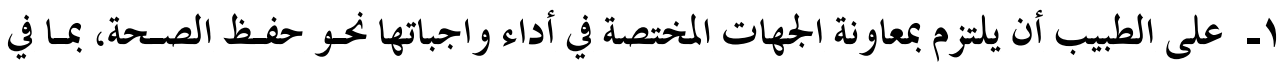
ذلك التبليغ عن الأمراض السارية، والأوبئة، حسبما يمليه النظام.

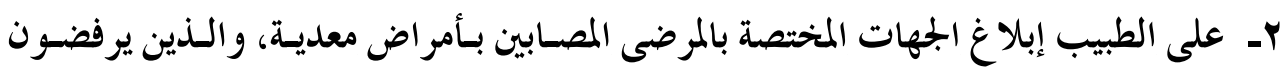

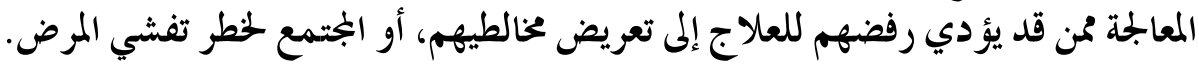
rـ على الطبيب أن يتخذ كافة الإجراءات اللازمة لوقاية نفسه من الأمر اض المعدية.

ع- على الطبيب أن يخضع نفسه للفحوصات اللازمة لتشخيص الأمراض المعدية لديه، إذا علم

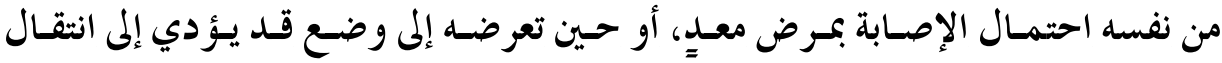

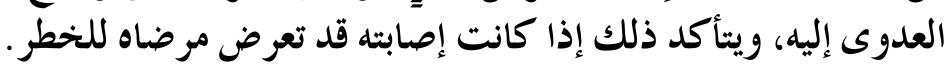

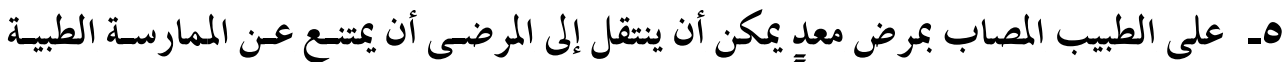

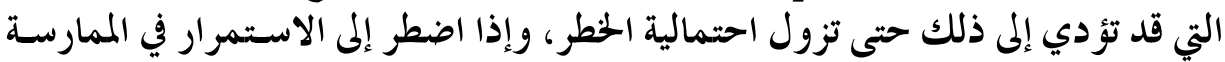

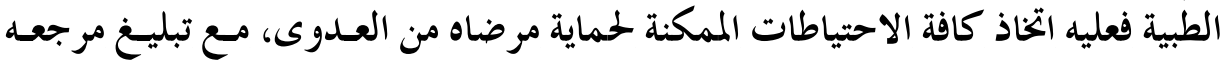

بذلك.

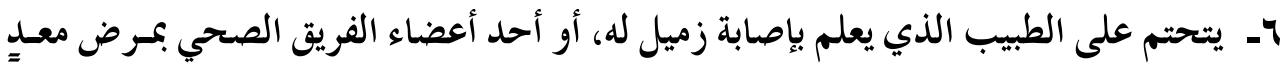

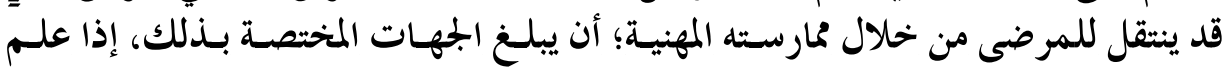

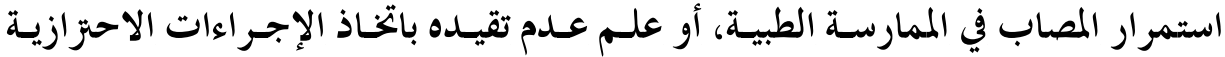

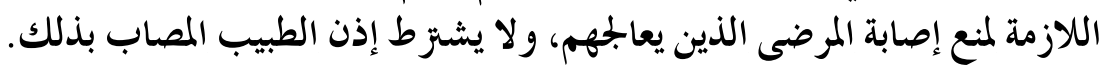

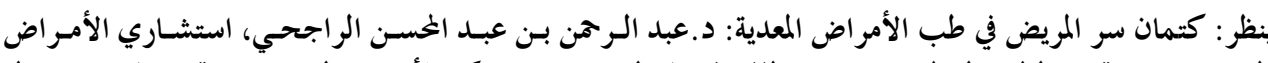

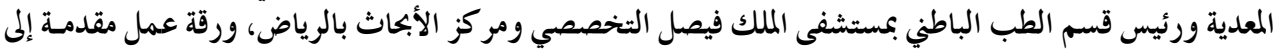

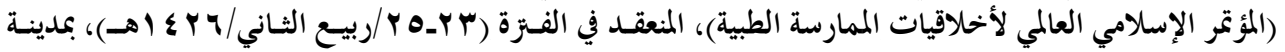




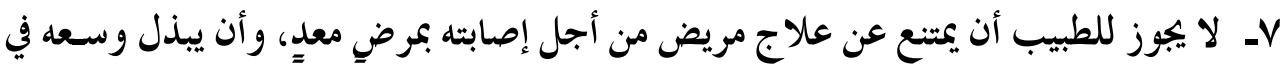
الاحتياط من انتقال المرض إليه.

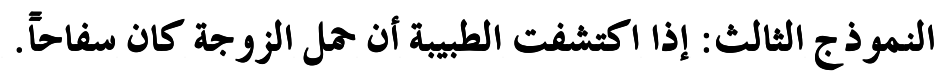

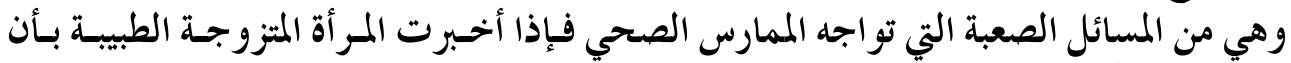

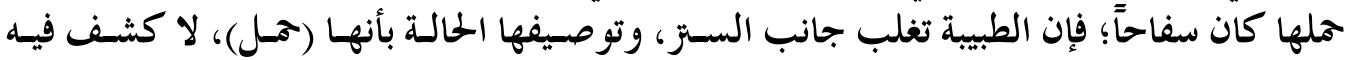

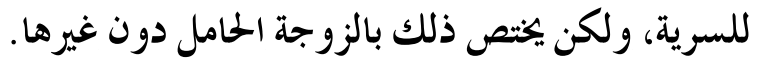

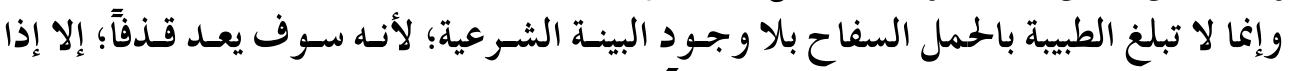

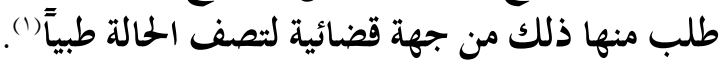

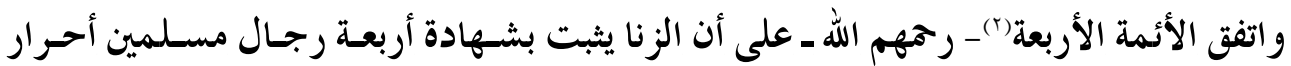

عدول، وهو أعلى البينات رتبة من حيث الإندة العدد (ب).

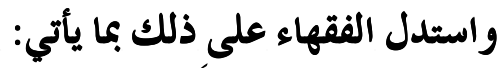

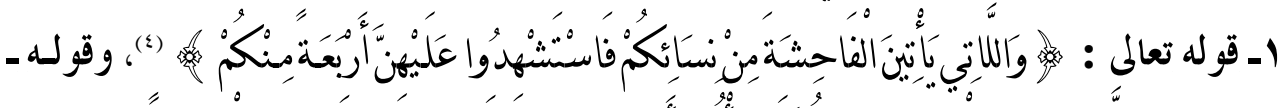

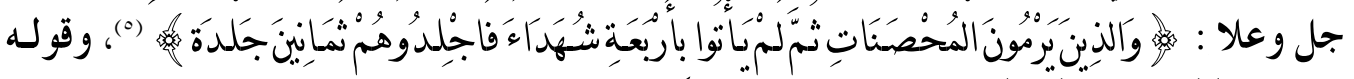

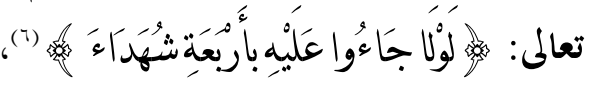

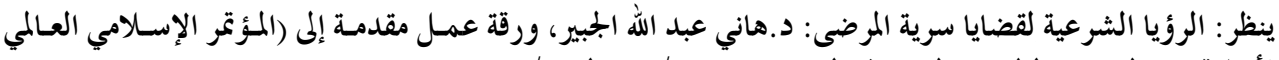

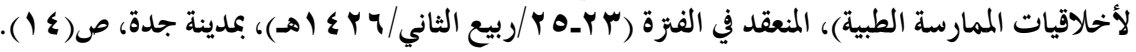

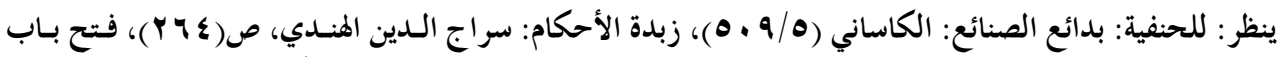

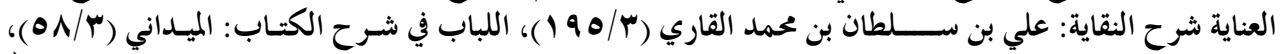

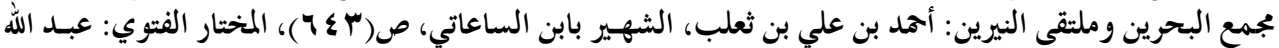

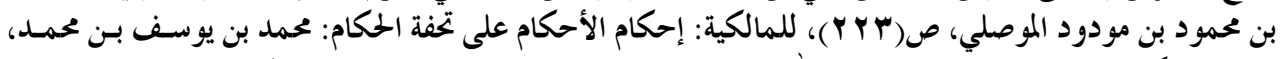

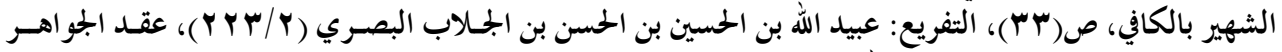

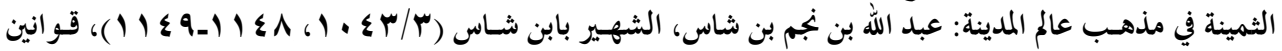

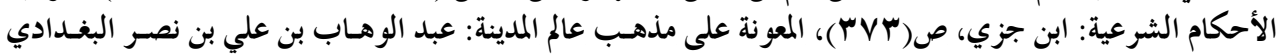

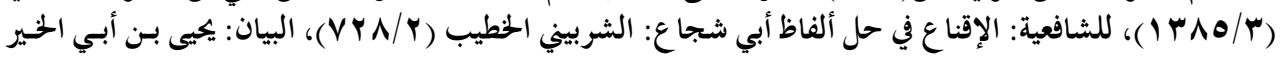

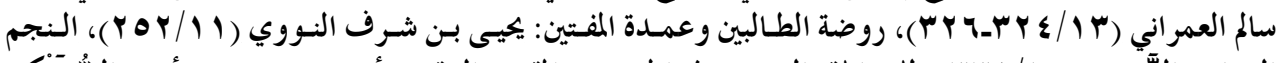

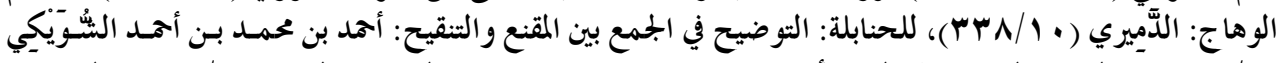

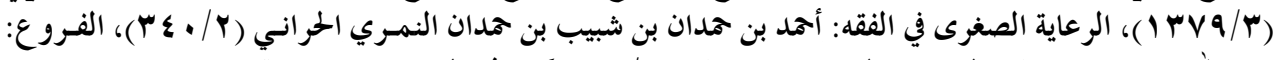

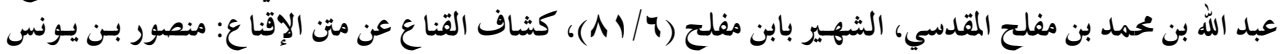

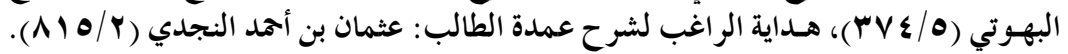

$$
\begin{aligned}
& \text { ينظر : عقد الجواهر الثمينة: ابن شاس (ب/ آ ـ ـ (1). } \\
& \text { سورة النساء، الآية (ه (1). } \\
& \text { سورة النور، الآية (ع) (الآية (1) } \\
& \text { سورة النور، الآية (T) (1). }
\end{aligned}
$$


وجه الدلالة: دلت الآيات الكريمة صر احة على أن الثهادة في الزنا لا بد فيها من أربعـة رجـال

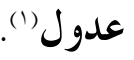

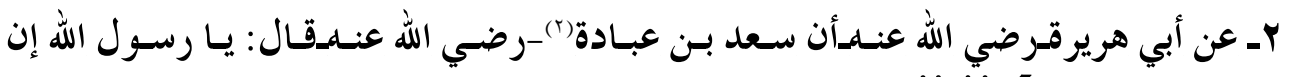

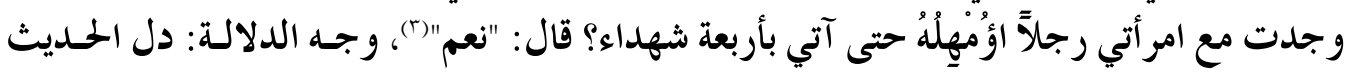

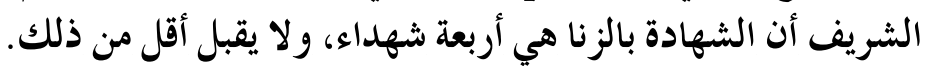

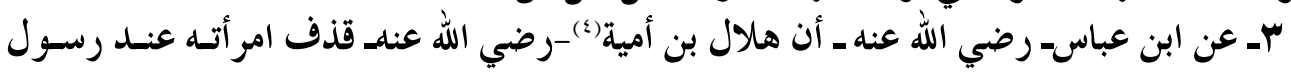

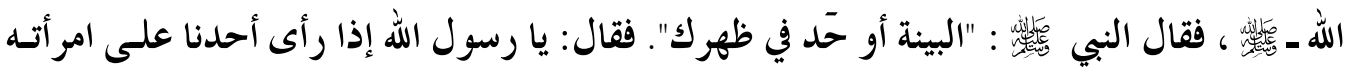

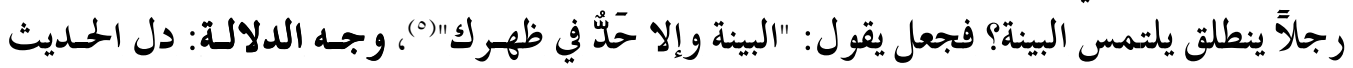

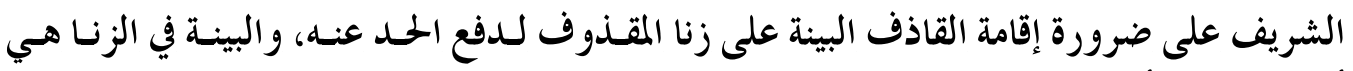
أربعة شهداء، أو الإقرار من الز إني.

عـ الإجماع، قال ابن المنذر (ج)-رحمه الله-: "أجمعوا على أن الشهادة على الزنا أربعـة لا يقبـل أقـل

ه- أن الشهادة بالزنا لا تكون بأقل من أربعة رجال، فغلظت فيه الشهادة ليكون أستز (^).

النموذج الرابع: كون المرأة غير متزوجة، واكتشفت الطبية أنها ليست بكرًا أو حاملاً.

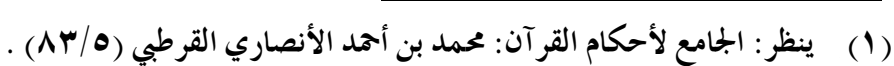

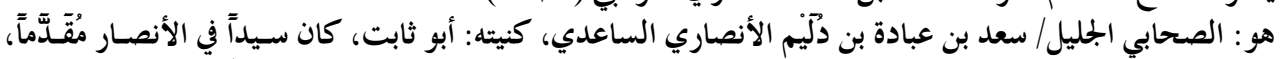

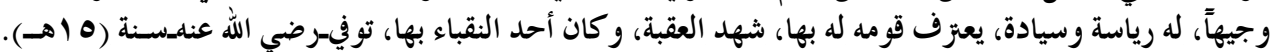

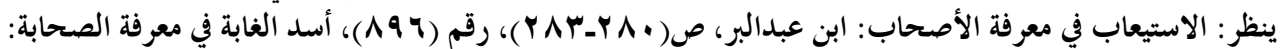

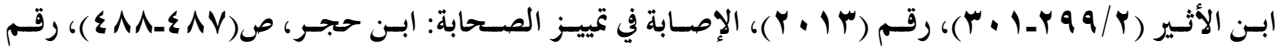

( أخ (T) (

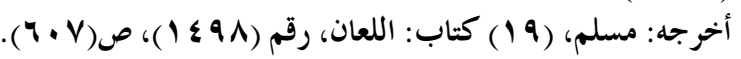

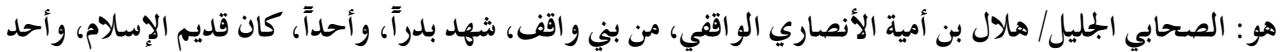

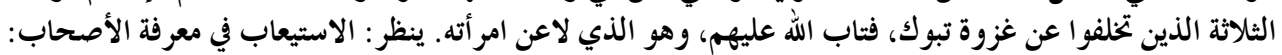

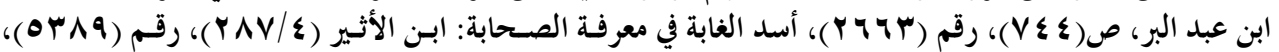

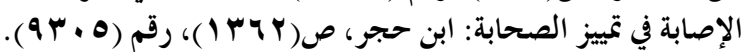

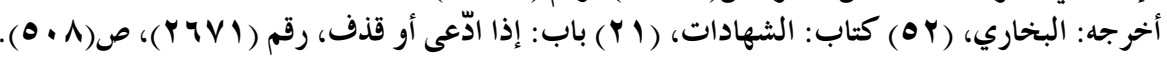

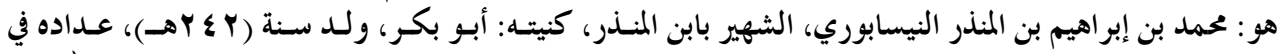

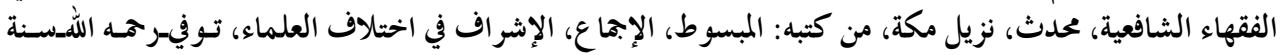

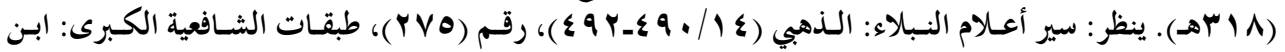

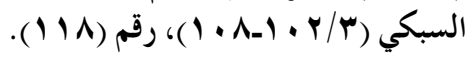

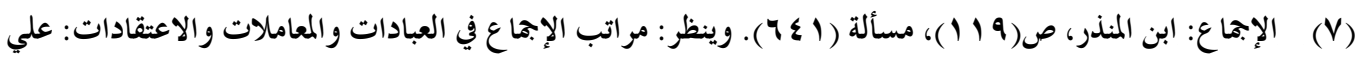

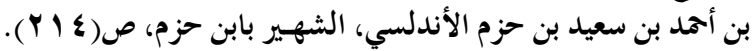

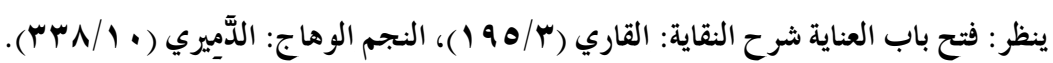


الجُتمع الإسلامي-وهو خير الجختمعات الإنسانيتـيرى أن "المثل والأخلاق و المكـارم ليســت حلـةً

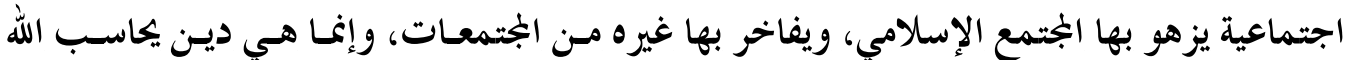

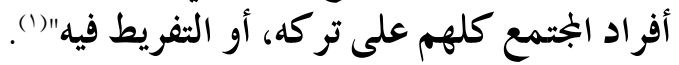

فالجُتمع الإسلامي تزدهر فيه العفة، والعفاف، و لا تشيع فيه الفاحشة، و المنكر، قال تعالى:

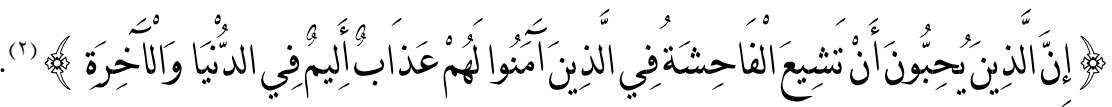

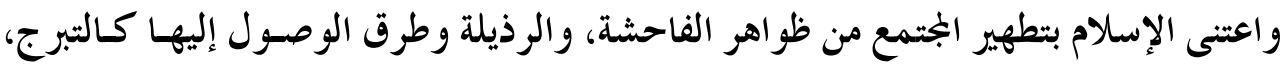

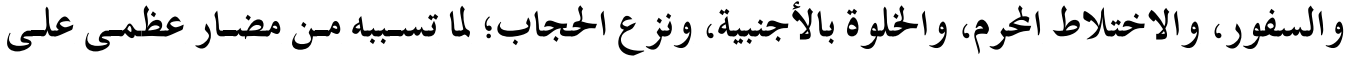

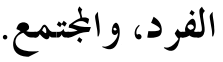

و من أصعب ما يواجه الأطباء القضايا التي تمس سياج الشرف، و العفة، ومن أمثلة ذلك("):

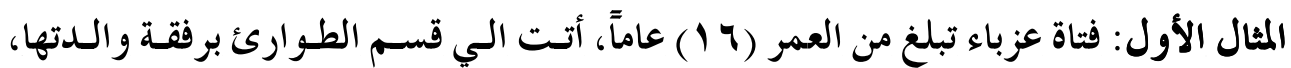

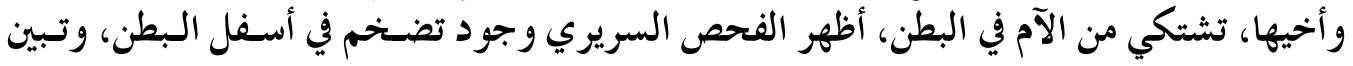

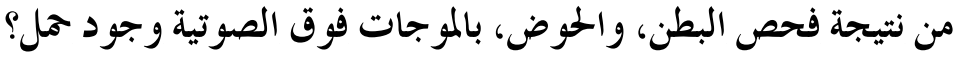

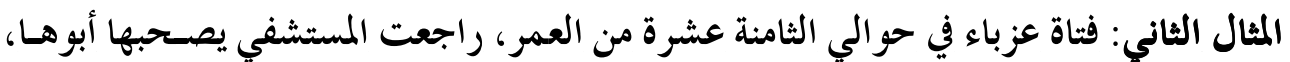

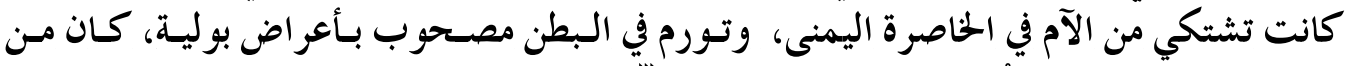

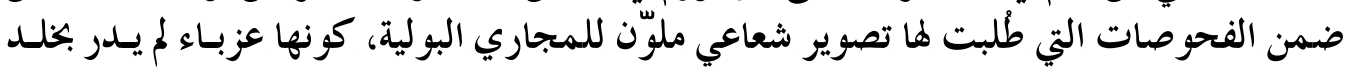

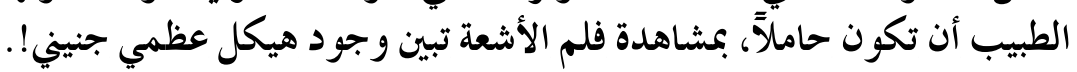

\section{وفي مثل هذه المالات المؤلمة:}

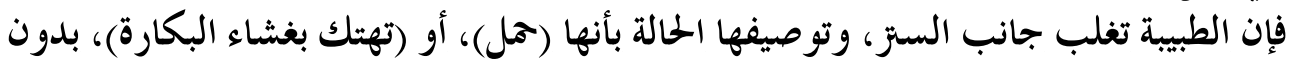

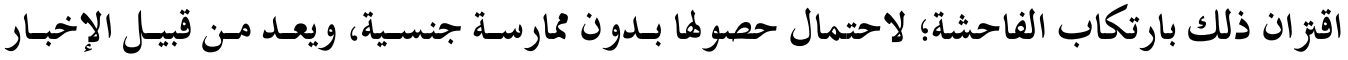

$$
\text { بالمرض، ولا كشف فيه للسرية. }
$$

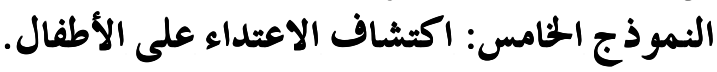

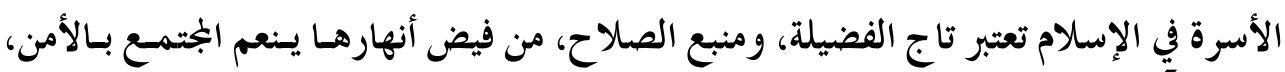

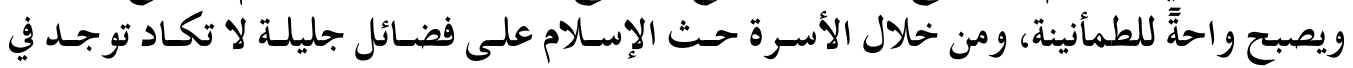

الجختمعات غير الإسلامية.

ينظر : الجتمع المسلم كما يبنيه الإسلام في الكتاب والسنة: د.محمد علي الهـاشي، ص( • (Y).

سورة النور، الآية (9 (1) ).

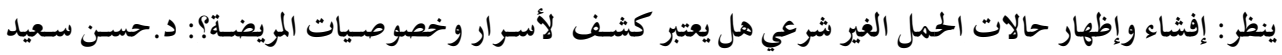

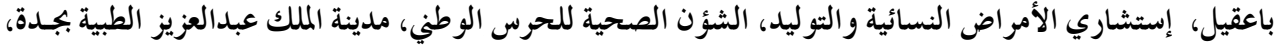

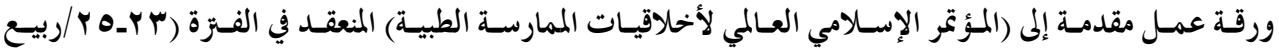




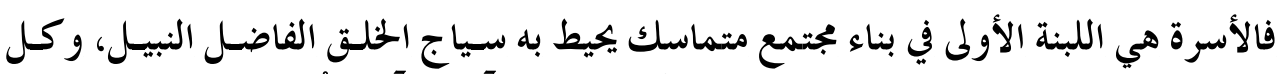

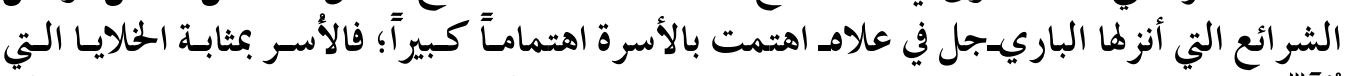

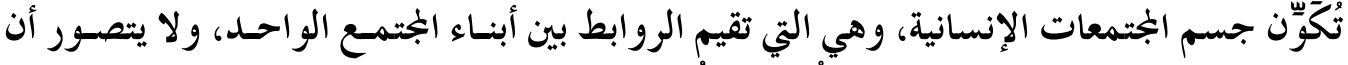

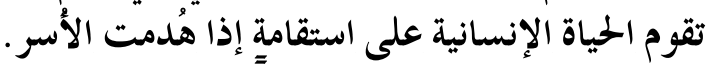

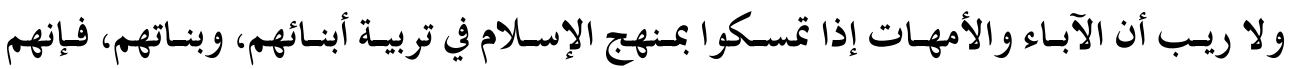

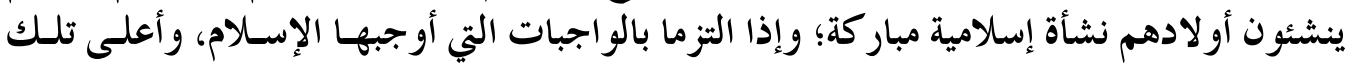

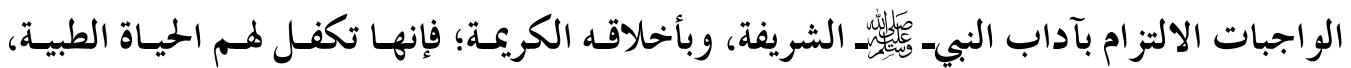

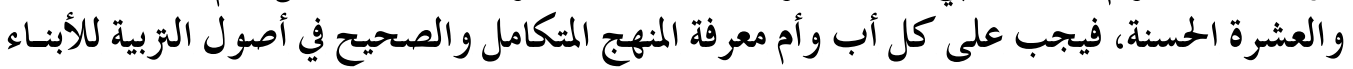
والبنات في ضوء القر آن الكريم والسينة.

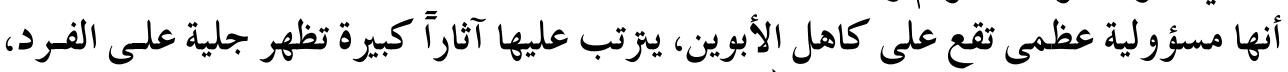

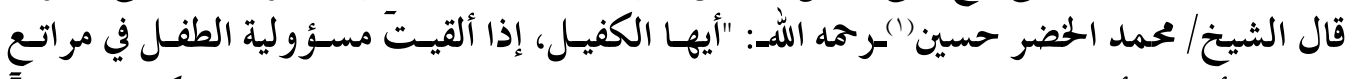

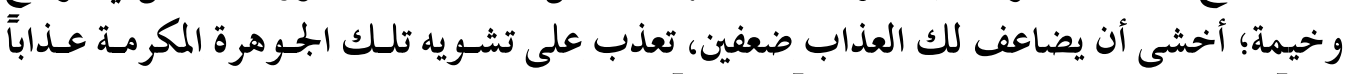

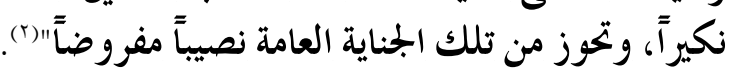

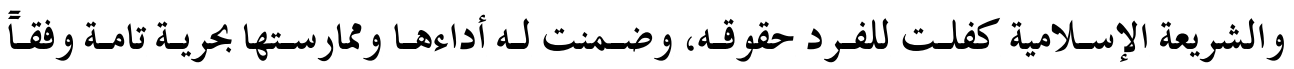

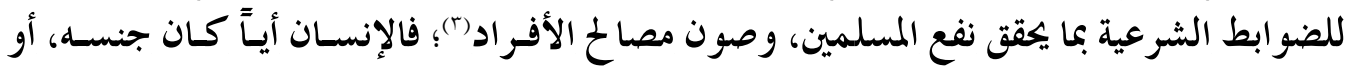

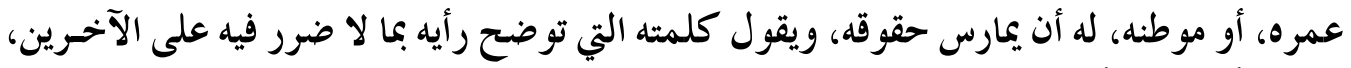

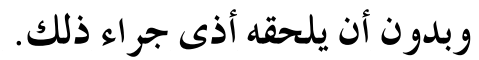

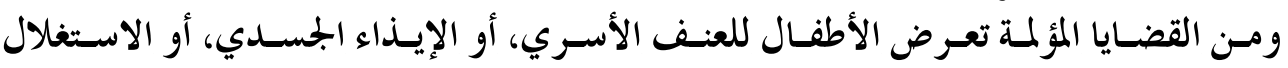

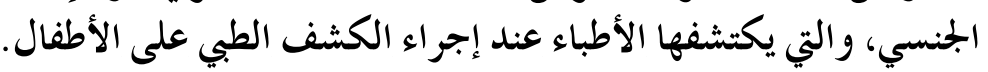

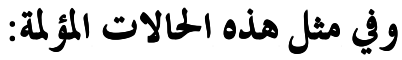
يجب على الأطباء إبلا غ الجهات المختصة في أي حالة اشتباه بوقوع جـرم جنـائي؛ كمـا جـاء في

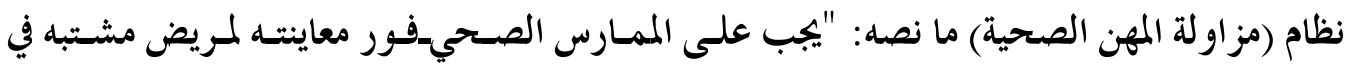
إصابته جنائياً، أو إصابته بمرض معدـأن يبلغ الجهات الأمنية، و الصحية المختصة "(s).

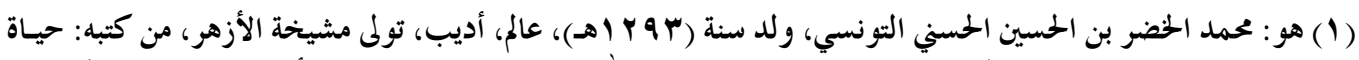

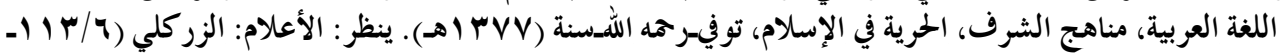

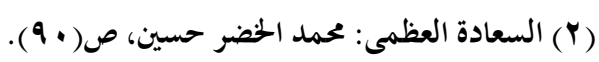

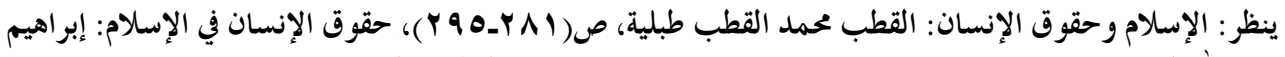

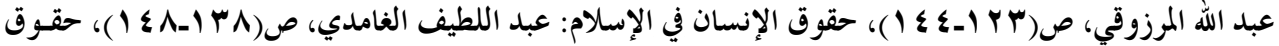

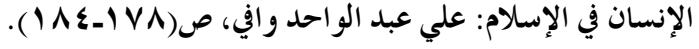
( () نظام مزاولة المهن الصحية: الفصل الثاني، الفرع الأول، المادة الحادية عشرة، ص(ب ا ). 
النموذج السادس: إذا كان المريض غير لائق للعمل.

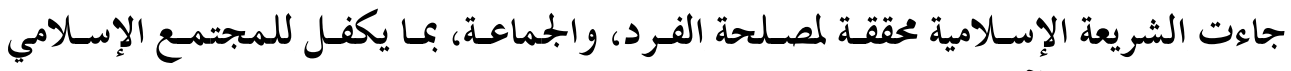
سلامته من الشرور والآفات الضارة بله.

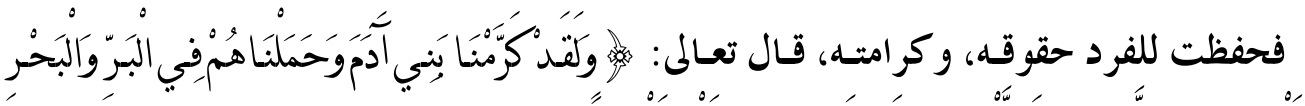

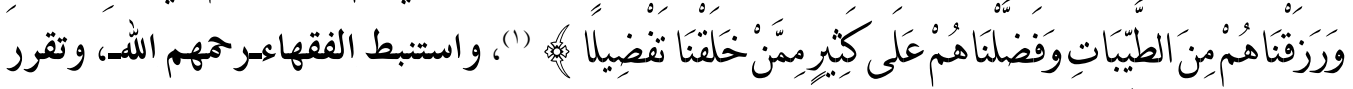
عندهم أن "الأفعال المباحة إنما تجوز بشرط عدم إيذاء أحد"(()، فقد حفظ الإسلام حرمة المسلم دمه،

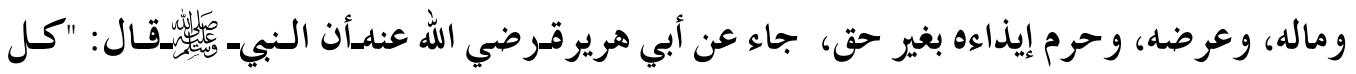

$$
\text { المسلم على المسلم حرام، دمه، وماله، وعرضه" ("). }
$$

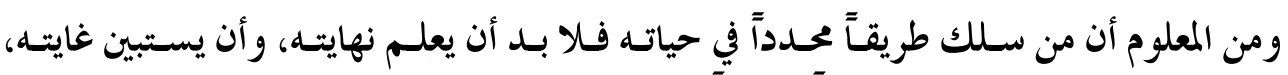

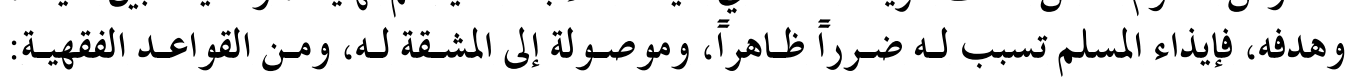

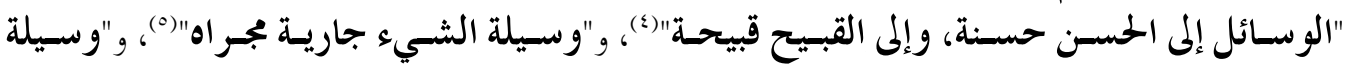

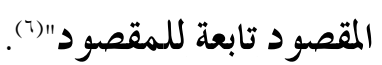

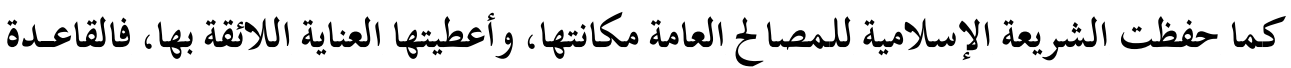

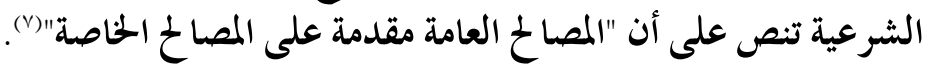

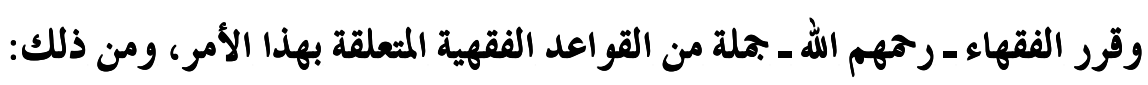

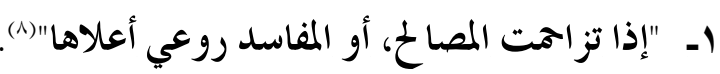

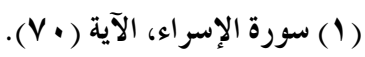

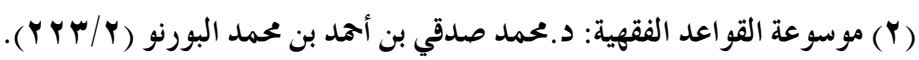

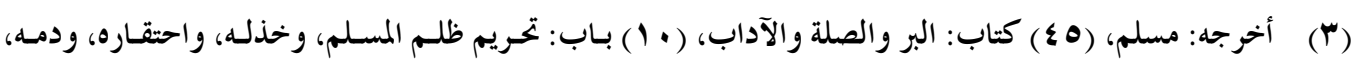

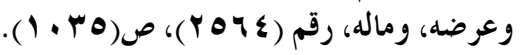

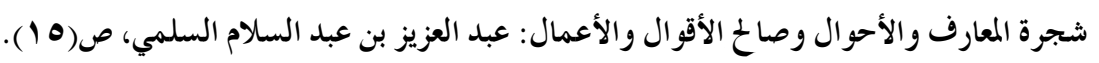

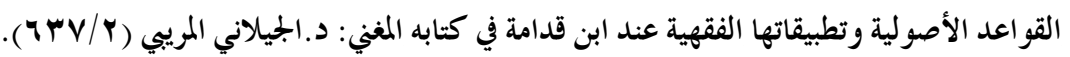

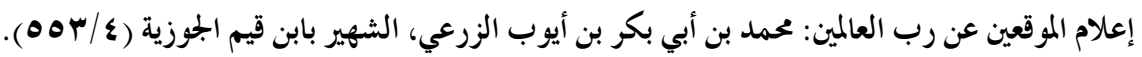

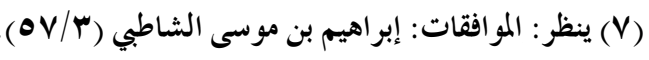

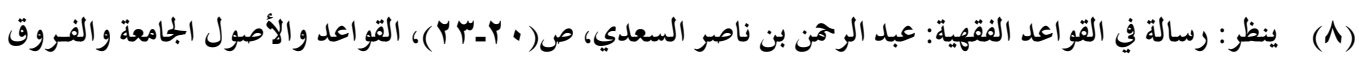

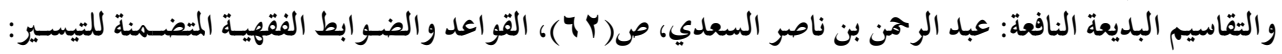

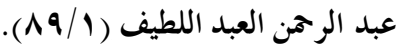




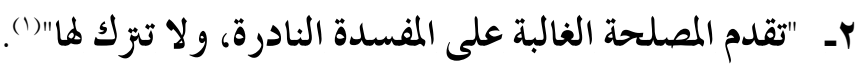

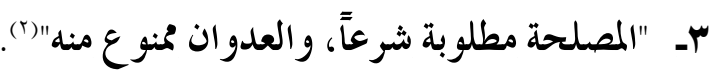

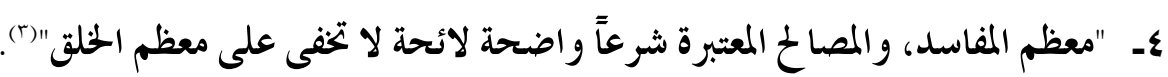

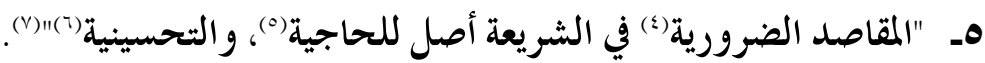

و ومن الوقائع التي تعرض للأطباء تعارض مصلحة الفرد الخاصة مع مصلحة الجُتمع؛ كمـا الحسال

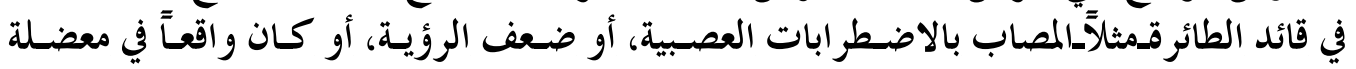

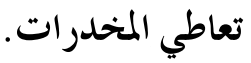

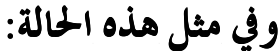

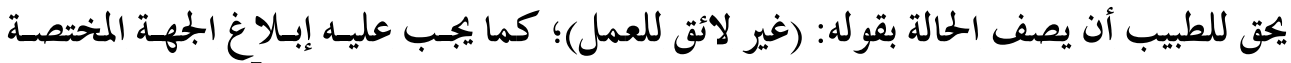

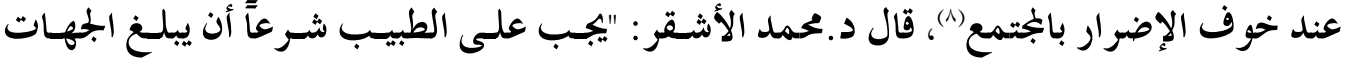

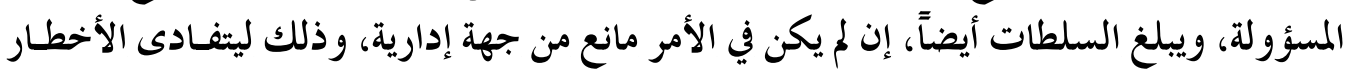

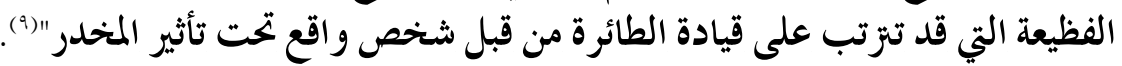
وجاء في قرارات مجمع الفقه الإسلامي الدولي ما نصه: "تستثنى من وجوب في كتمان فئمان السر

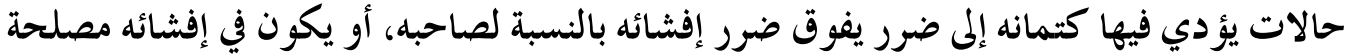

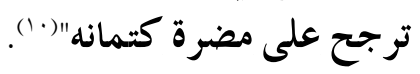

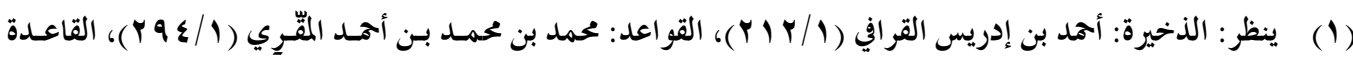
)

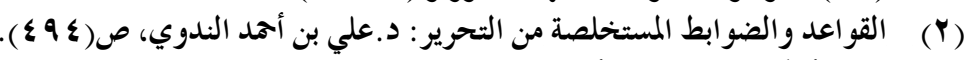

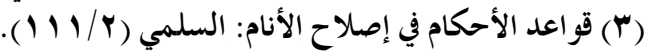

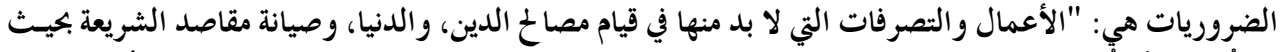

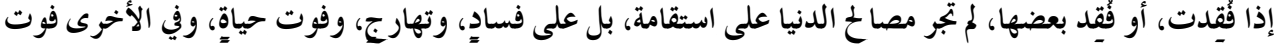

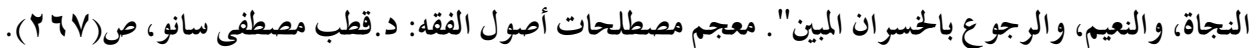

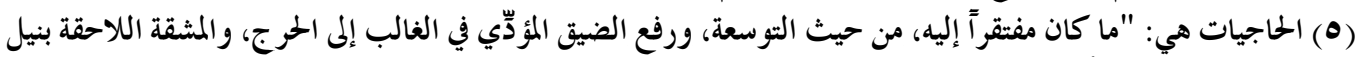

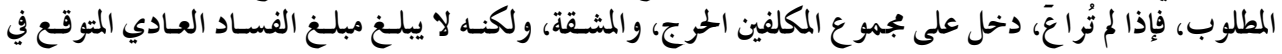

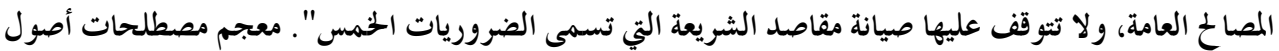

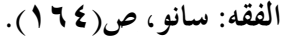

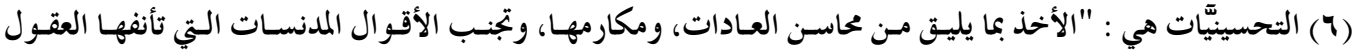

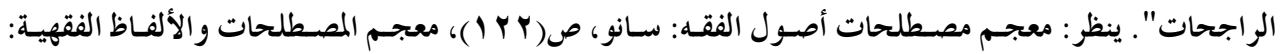

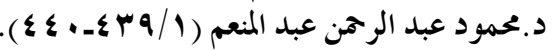

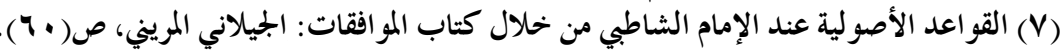

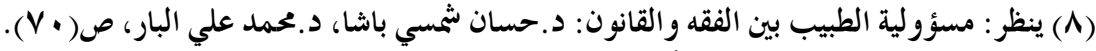

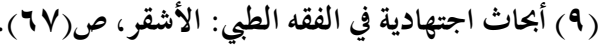

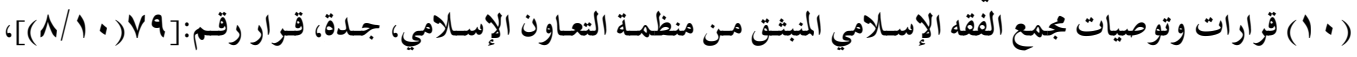




\section{الفصل الرابع \\ واقع السر الطبي في أنظمة المملكة العربية السعودية \\ المبحث الأول}

\section{تاريخ الطب في المملكة العربية السعودية.}

يسعى أفر اد الجُتمع أياً كان نوعه، ودرجـة رقيـه، وتقدمـه؛ إلى اللحـاق بركـب الحضـارة، فِإن مستوى الأمة في سلم الحضارة يقاس بمستوى تقدمها العلمي، و النهضة العلمية هي الهـدف الأسمى

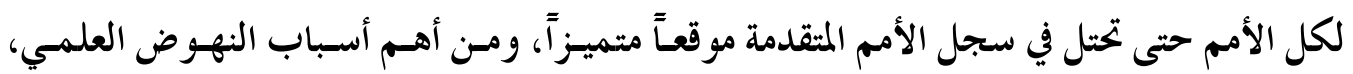
وأبرز سماته؛ هو اهتمام الأمة العميق بالعلم، ورسالة القلم، وأمتنا عبر تاريخها الجزيد هي أمة المعرفـة،

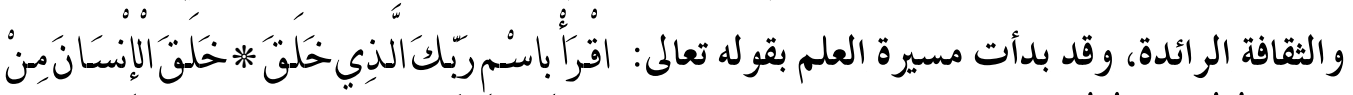

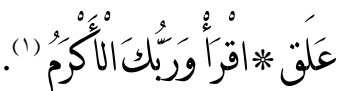

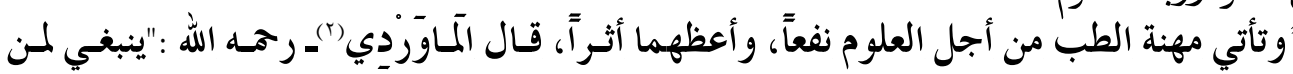

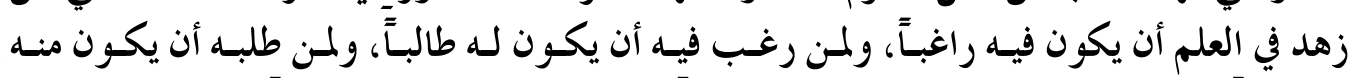

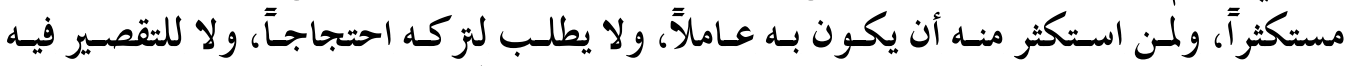

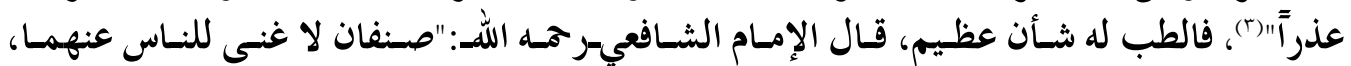

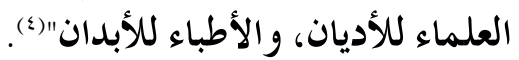

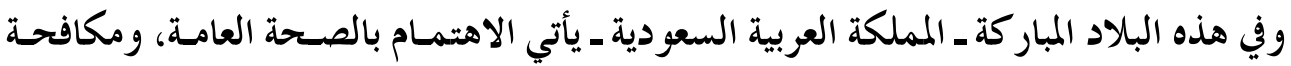

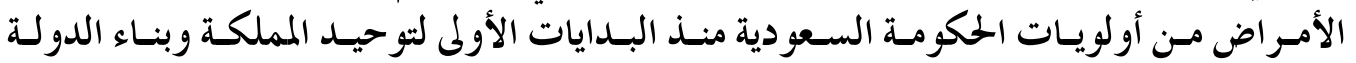

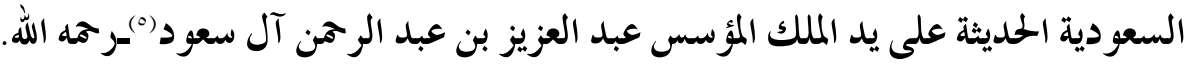

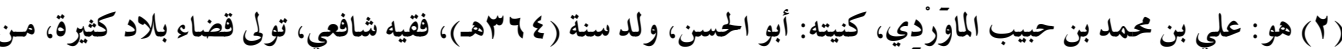

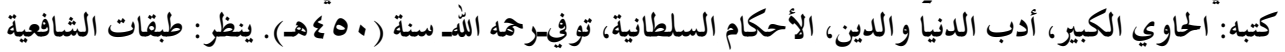

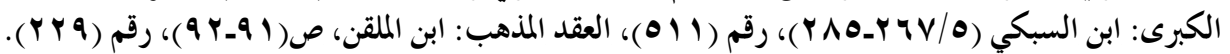

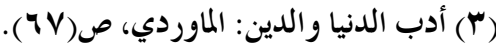

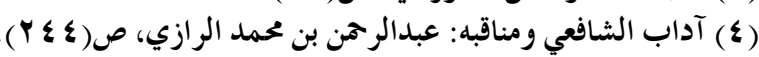

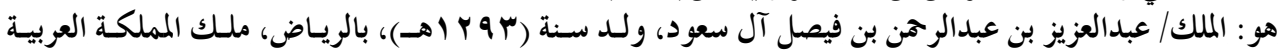

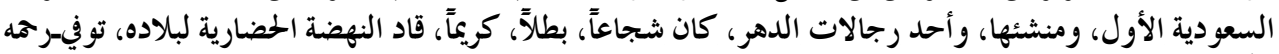

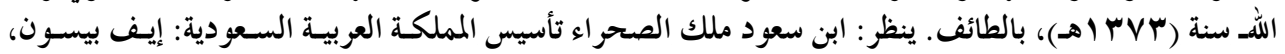

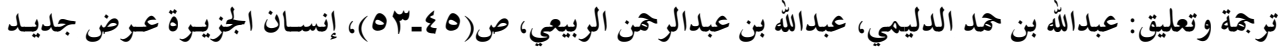

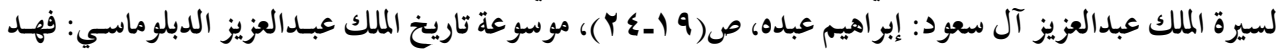




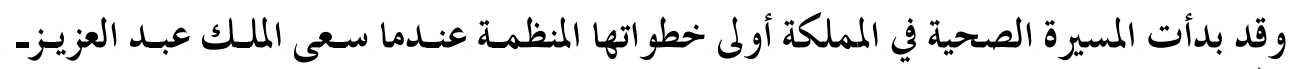

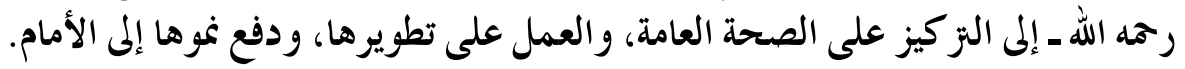

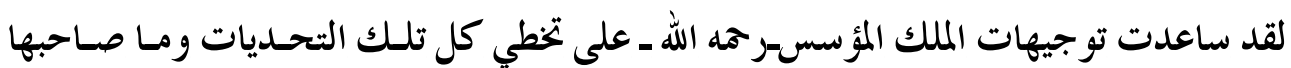

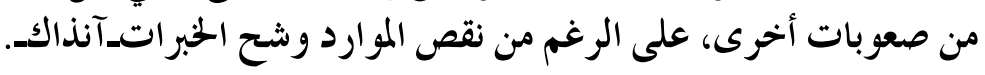

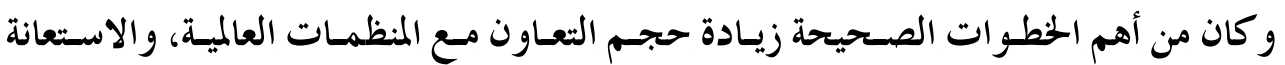

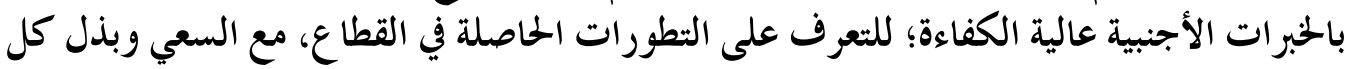

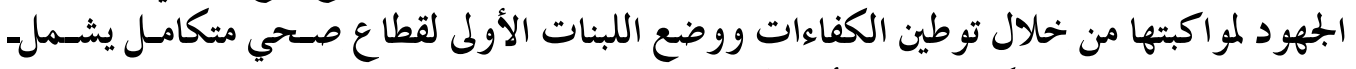

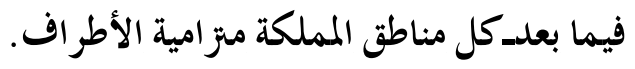

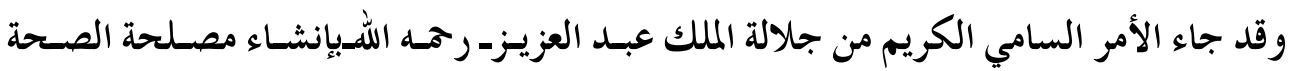

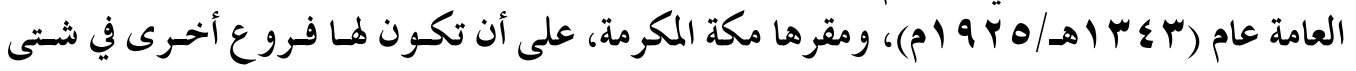
المناطق (1)

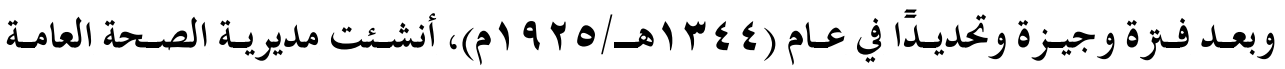

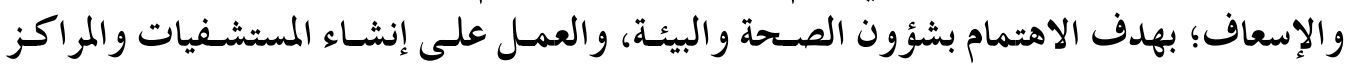

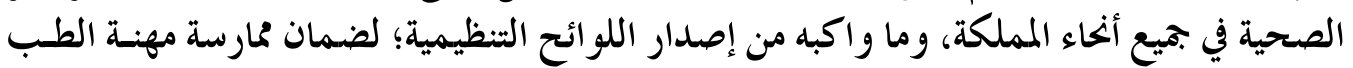

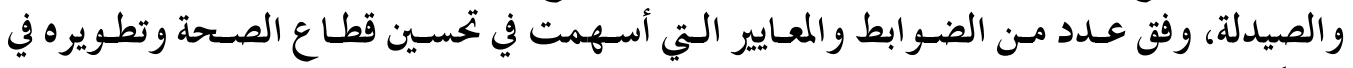
المملكة.

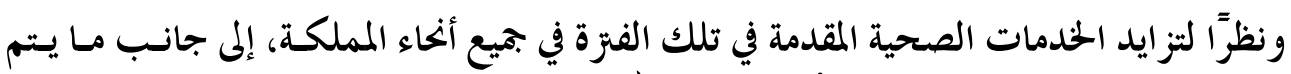

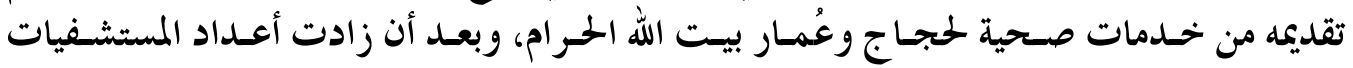

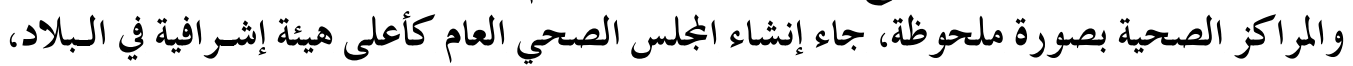

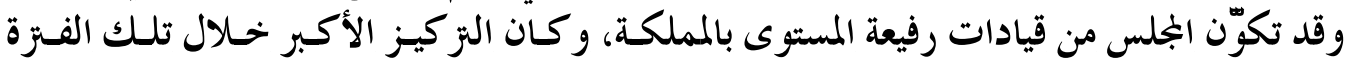

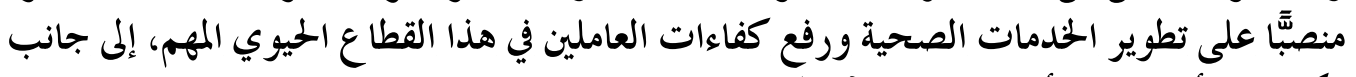
مكافحة الأمر اض والأوبئة المنتشرة آنذاك الصدئ

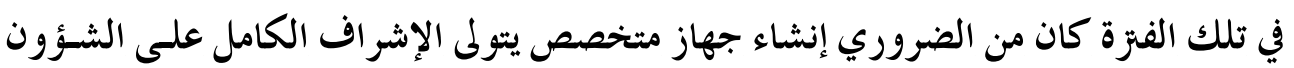

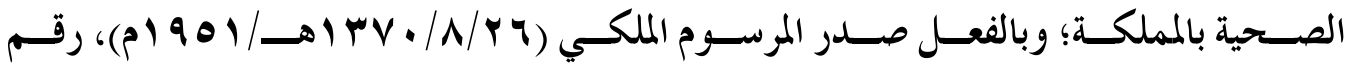

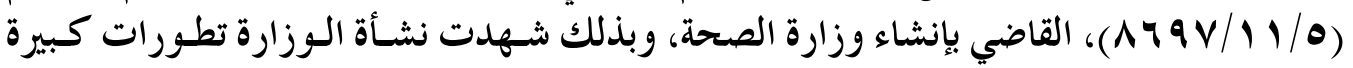

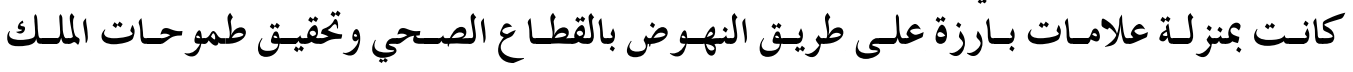
عبد العزيز.

\footnotetext{
بن عبدالله السماري وآخرون، ص( آY )، و اقع الضبط البيليوجرافي للإنتاج الفكري عن الملك عبدالعزيز آل سعود: سالم بن محمد السالم، صب( • ع ).

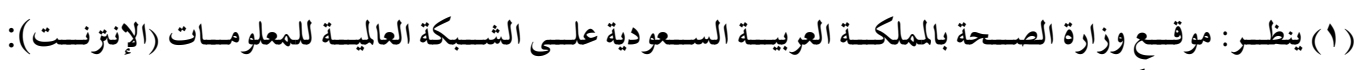
wWw.moh.gov.sa
} 
وفيما تاريخ موجز لصدور الأنظمة المتعلقة بالمهن الصحية في بلادنا المبار كقدأدام الله عزهاـ(1):

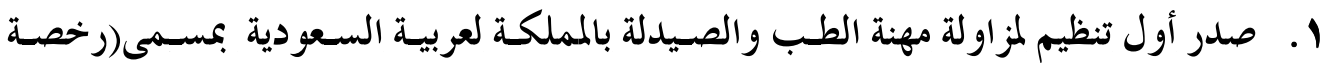

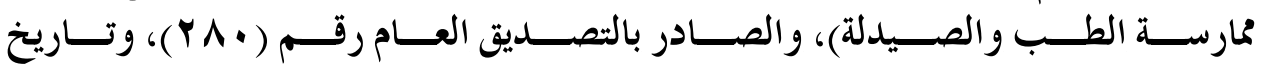

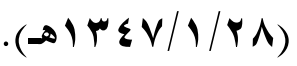

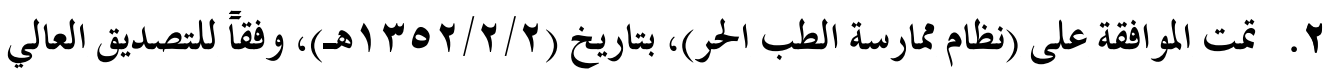

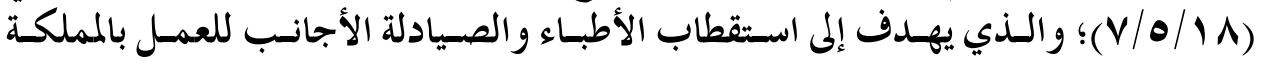

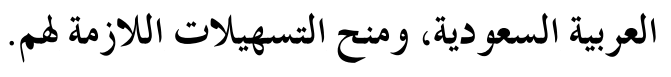

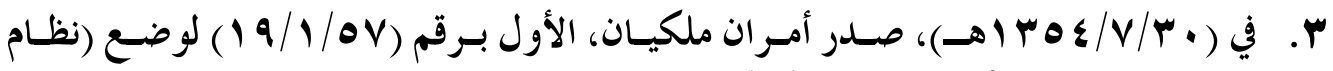

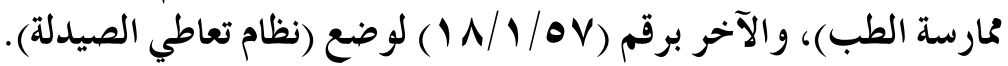

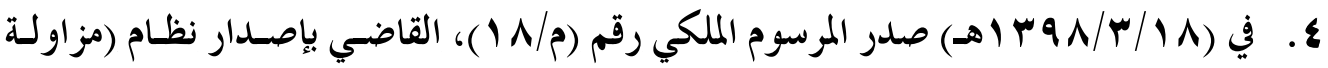

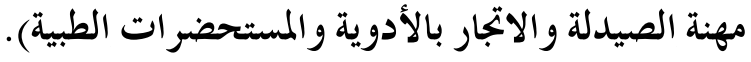

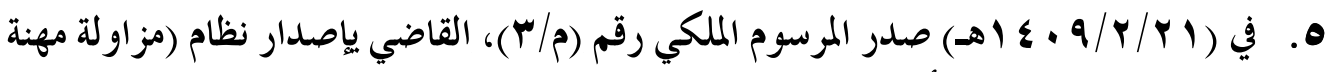
الطب البشري وطب الأسنان).

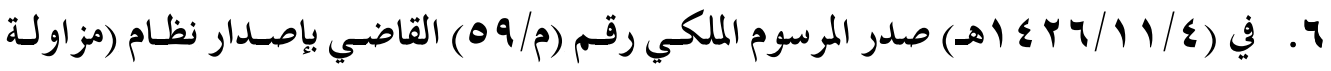

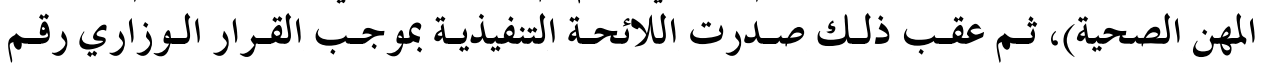

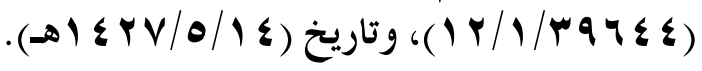

وفيما يلي قائمة كليات الطب في المملكة العربية السعودية(؟):

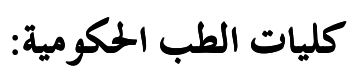
كلية الطب بجامعة الملك سعود بن عبد العزيز للعلوم الطبية بالرياض وجدة. 1 ـ كلية الطب بجامعة الفيصل بالرياض. Y. كلية الطب بجامعة الملك سعود بالرياض.

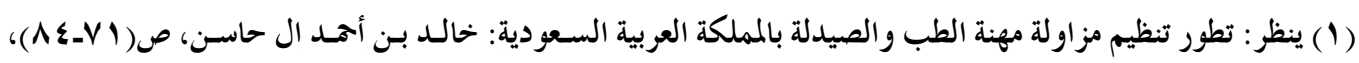

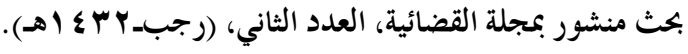

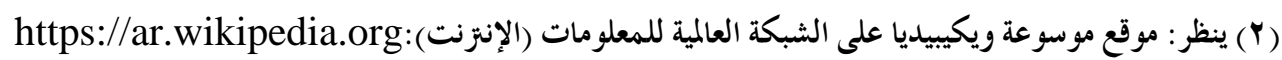


r. كلية الطب بجامعة الججمعة.

ع. كلية الطب بجامعة الملك عبد العزيز بجدة.

ه. كلية الطب بجامعة الملك فيصل بالإحساء.

7. لية الطب بجامعة الدمام.

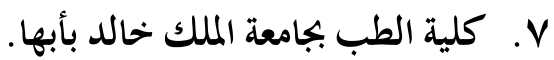
A. كلية الطب بجامعة أم القرى بمكة المكرمة.

9 ـ كلية الطب بجامعة طيبة بالمدينة المنورة.

• 1 . . كلية الطب بجامعة الطائف.

11 إ. كلية الطب بجامعة القصيم.

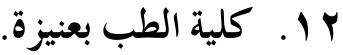

با 1. كلية الطب بجامعة الباحة.

ع ا ـ كلية الطب بجامعة حائل.

ه 1 . كلية الطب بجامعة تبوك.

I 1 ـ كلية الطب بجامعة نجر ان.

1 ا . كلية الطب بجامعة عسير.

1 1 ـ كلية الطب بجامعة الحدود الشمالية.

9 19. كلية الطب بجامعة الجوف.

• . . . . كلية الطب بجامعة جازان.

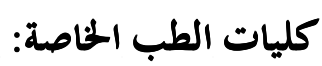

I. كلية ابن سينا للعلوم الطبية الأهلية بجدة.

Y. . كلية البتزجي الأهلية للعلوم الطبية و التقنية بجدة. 
ب. كليات الفارابي الأهلية في الرياض وجدة. ع. ـليات الرياض لطب الأسنان و الصيدلة. ه. كليات سليمان الراجحي الأهلية بالبكيرية. צ. كلية العناية الأهلية للعلوم الطبية بالرياض. V. كليات الغد الدولية للعلـوم الصـحية في الريـاض وجـدة والـدمام وأبها و القصسيم وتبـوك ونجر ان و المدينة المنورة وحفر الباطن. 1. ـ ـليات بريدة الأهلية. 9 . كليات المعرفة للعلوم و التقنية الأهلية بالرياض. 


\section{السر الطبي في أنظمة المملكة العربية السعودية}

الشريعة الإسلامية هي شريعة شاملة و كاملة، فلا يوجد خير إلا دلت عليه، ولا شر أو ضرر إلا ونهت عنه، فهي شريعة خالدة صالحة لكل زمان ومكان، تحقق مصالح العباد، وتدفع عنهم المفاسد،

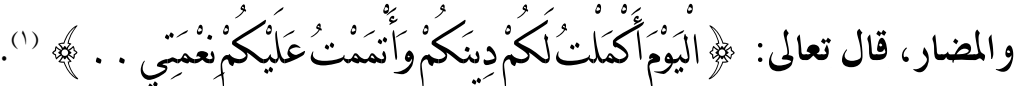

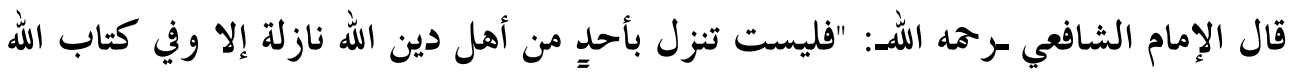
الدليل على سبيل المدى فيها" ('). ولا ريب أن المسلم ينطلق في حياته، وتعامله، وجميع تصرفاته من تطبيق أحكام الشريعة الإسلامية، فهو يحرص عليها علماً، وعملاً، ويسعد بمعرفتها؛ لتكون هذه المعرفة سبيلاً إلى حُسن

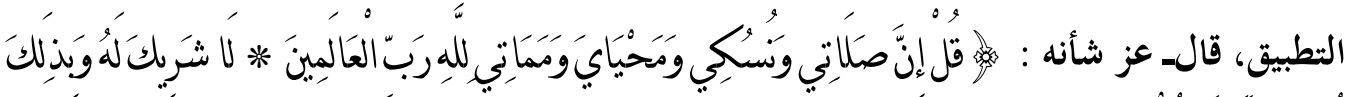

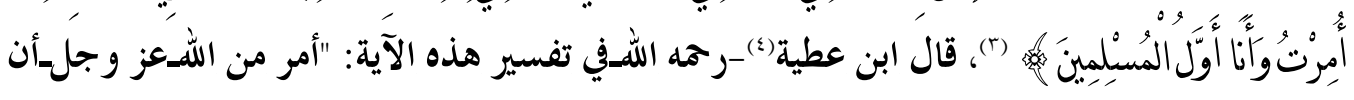
يعلن بأن مقصده في صلاته، وطاعته من ذبيحة وغيرها، وتصرفه مدة حياته، وحاله من الإخلاص،

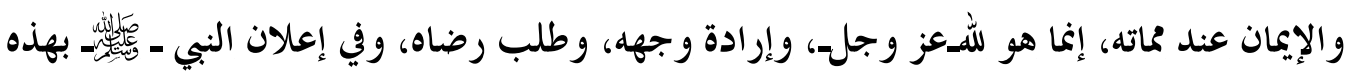
المقالة ما يلزم المؤمنين التأسي به حتى يلتزموا في جميع أعمالهم قصد وجه اللهـعز وجل-"(•).

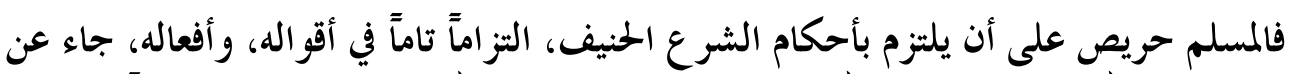

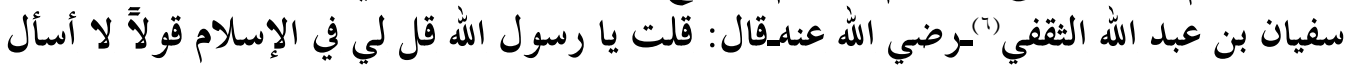

$$
\begin{aligned}
& \text { سورة المائدة، الآية (ب). }
\end{aligned}
$$

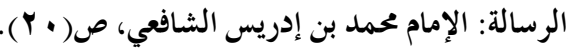

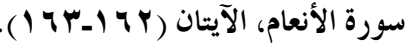

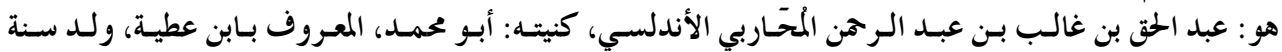

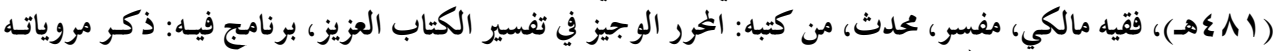

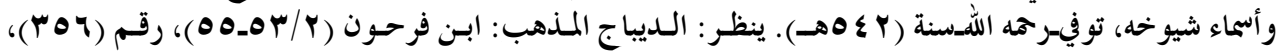

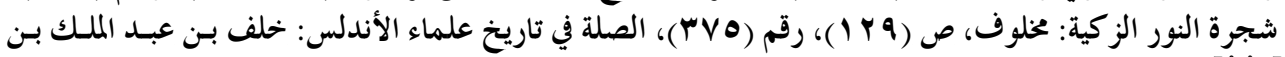

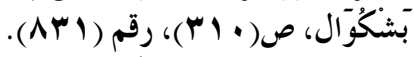

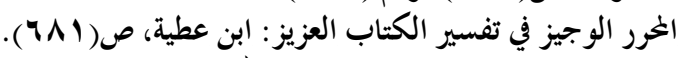

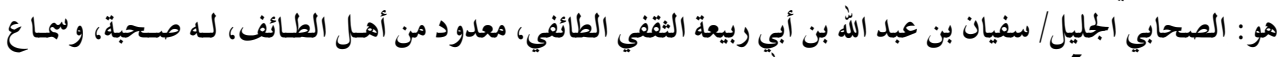

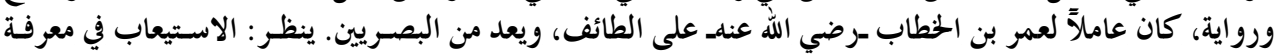

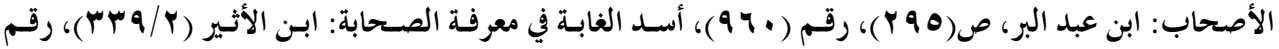

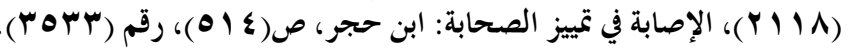


عنه أحداً بعدك، قال: "قل آمنت بالله فاستقم" (1).

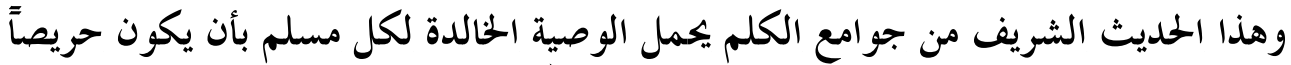

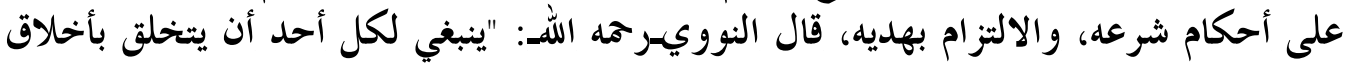

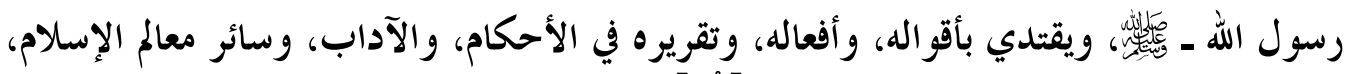

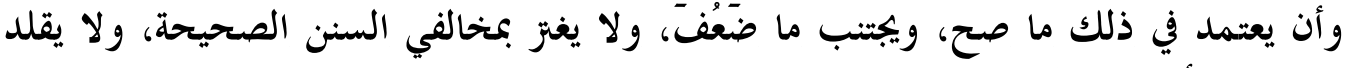

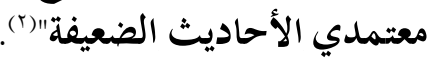

ويمتاز الجختمع الإسلامي عن غيره من الجتمعات بتمسكه بتطبيـق الشـريعة الإسـلامية في مختلـف

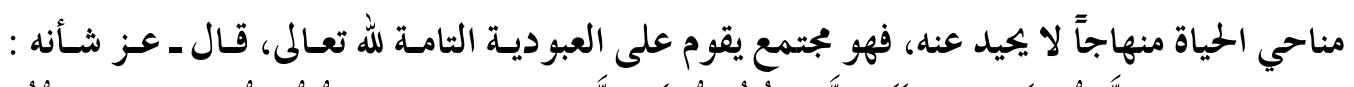

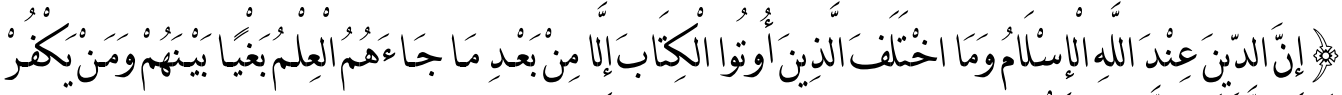

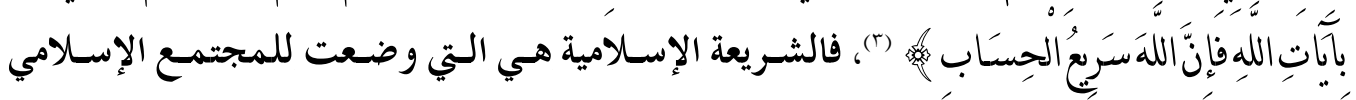
أسسه، و وسماته، ومقوماته، وهذا هو سر تميز الجزتمع المسلم عن بقية الجتمعات.

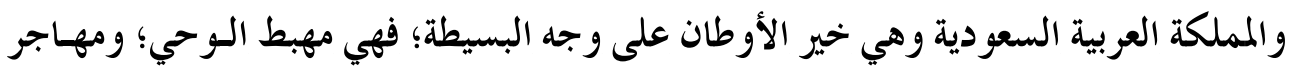

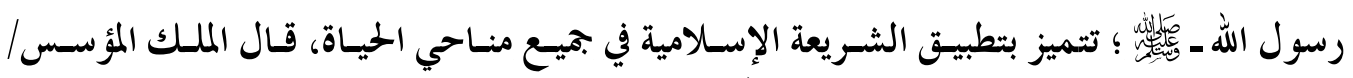

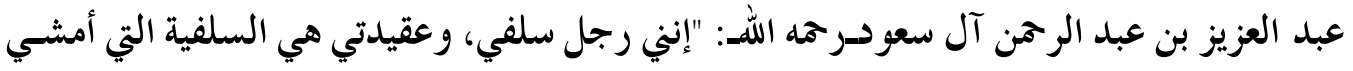

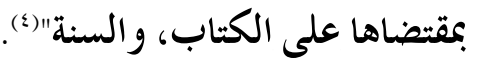

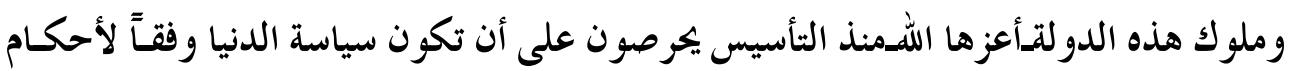

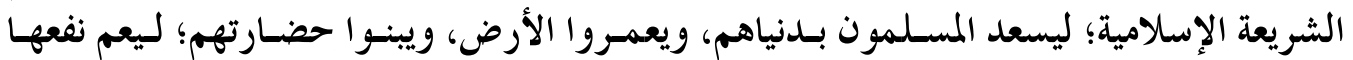

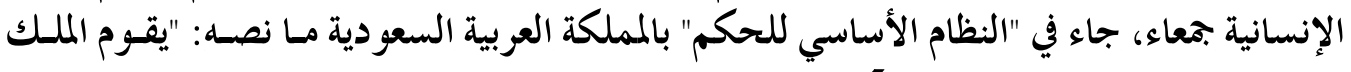

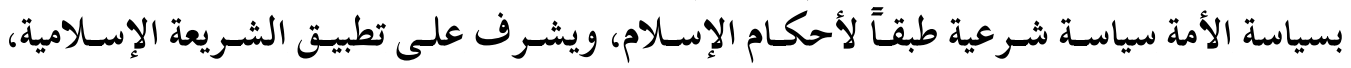

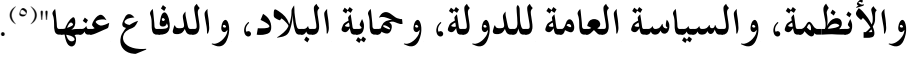

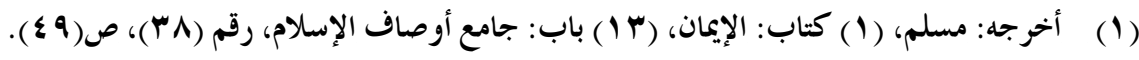

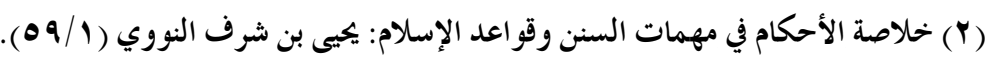

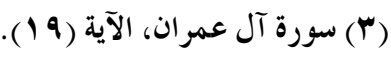

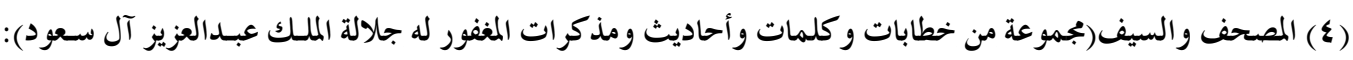
محيى الدين القابسي، ص( • ب ا).

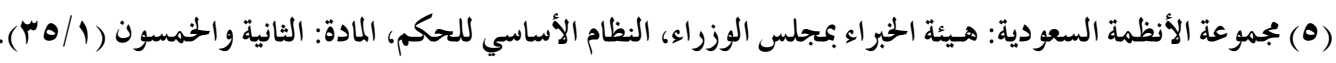




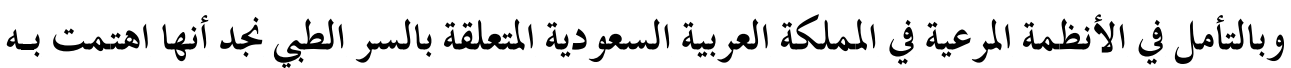

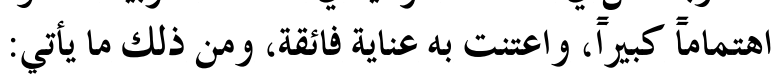

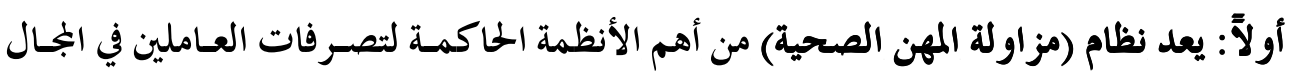

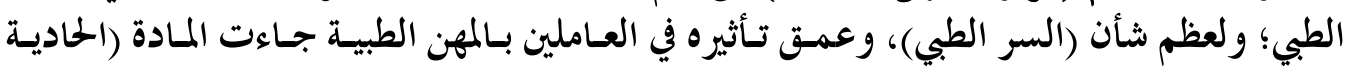

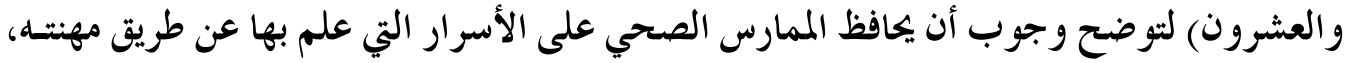
ولا يجوز له إفشاؤها إلا في الأحوال الآتية (1) :

\section{( ) إذا كان الإفشاء مقصوداً به:}

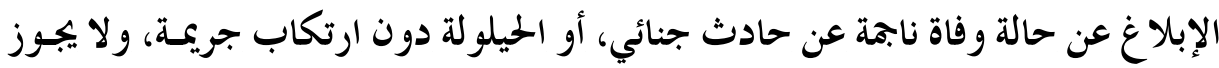

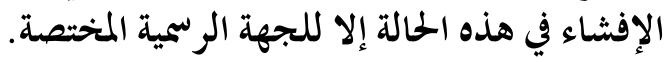

$$
\text { الإبلا غ عن مرض سارِ، أو معد. }
$$

دفع الممارس لاتهام وجهه إليه المريض، أو ذووه يتعلق بكفايته، أو بكيفية ممارسته لمهنته. إذا و افق صاحب السر كتابة على إفشائه، أو كان الإفشاء لذوي المريض مفيداً لعلاجه.

إذا صدر له أمر بذلك من جهة قضائية.

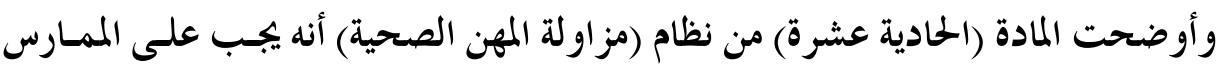

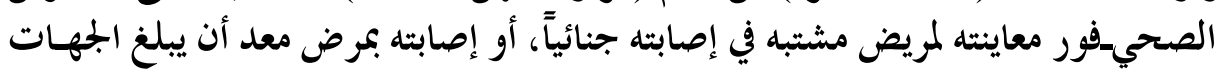

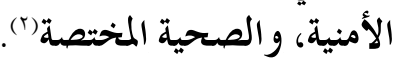

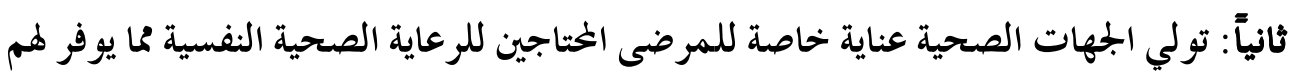

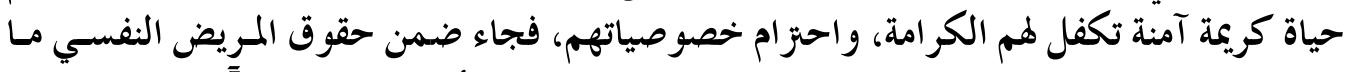

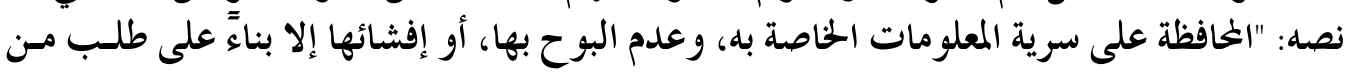

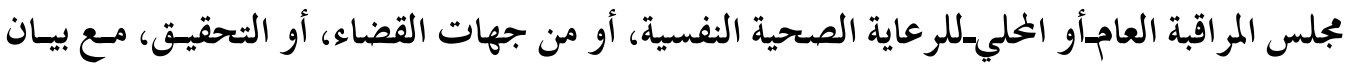

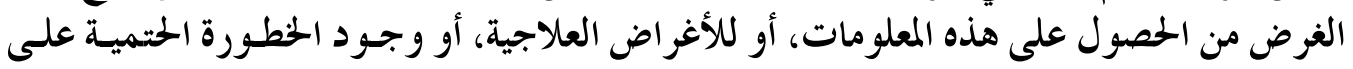

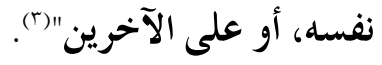

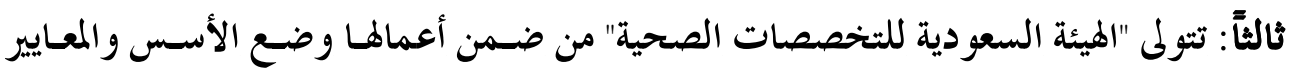

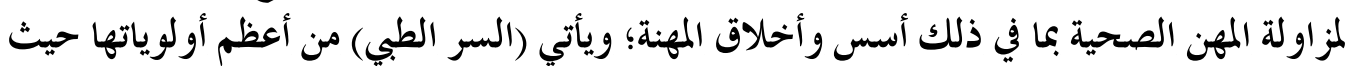

(1) ينظر : نظام مزاولة المهن الصحية، الفصل الثاني، الفرع الثاني، المادة الحادية والعشرون، ص(V) (IV).

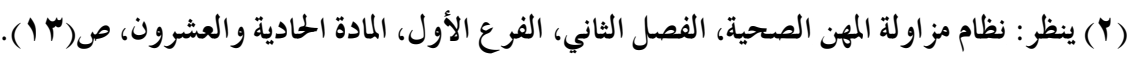

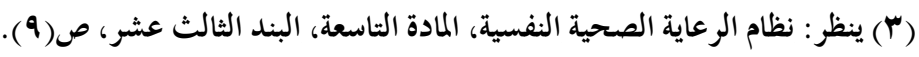


أكدت على ضرورة حفظ السر، والاعتناء به، و السـتز على المسـلم، وبينـت الحسالات الاستثنائية

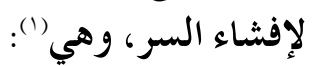

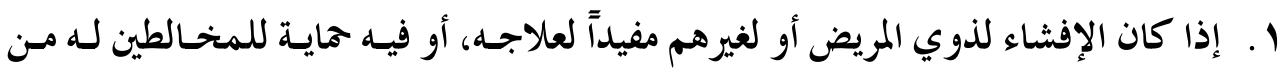

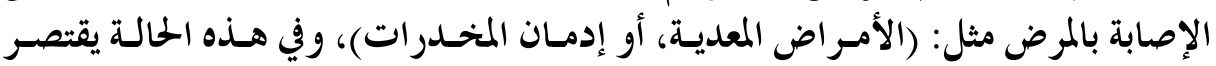
الإخبار على من يمكن أن يضار.

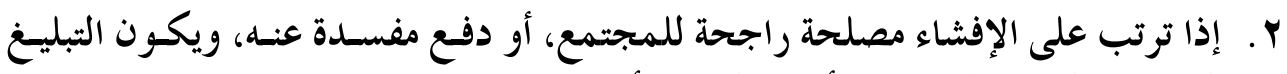

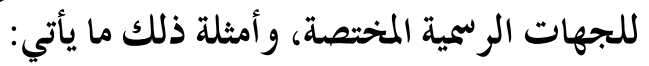
الإبلاغ عن وفاة ناجمة عن حادث جنائي، أو للحيلولة دون ارتكاب جريمة. التبليغ عن الأمر اض السارية، أو المعدية. إذا طلب منه ذلك من جهة قضائية.

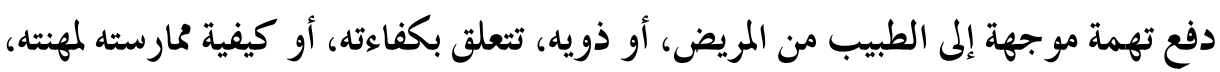
على أن يكون الإفشاء أمام الجحهات الرئية من الريمية. ( ) الإفضاء لغرض التعليم: (1)

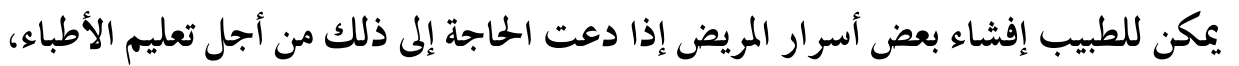

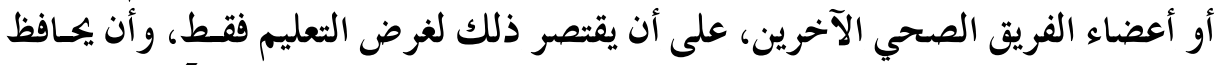

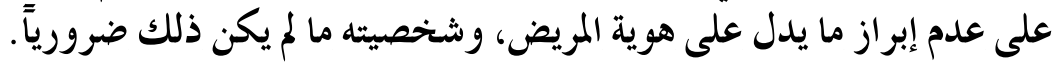

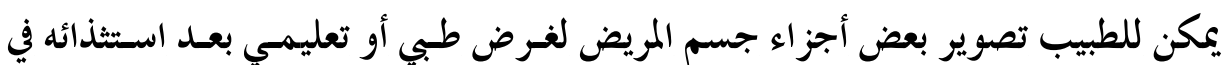

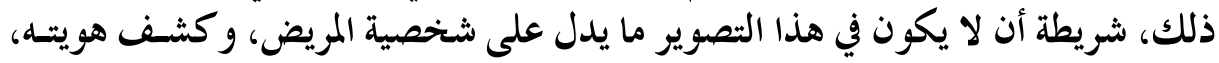

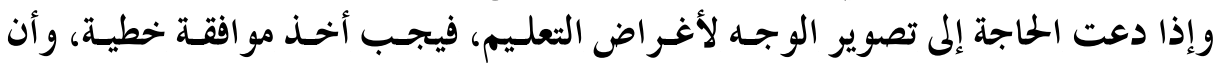
تغطى العينين إلا للضرورة العلمئة

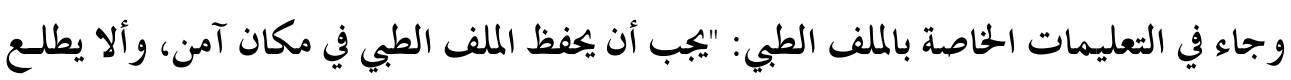

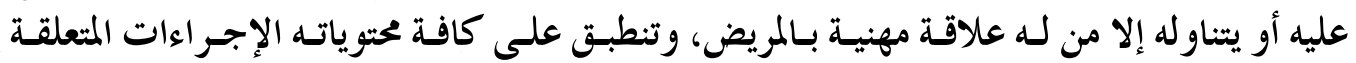

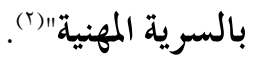

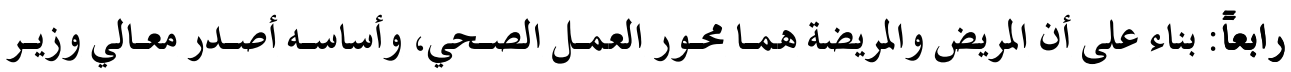

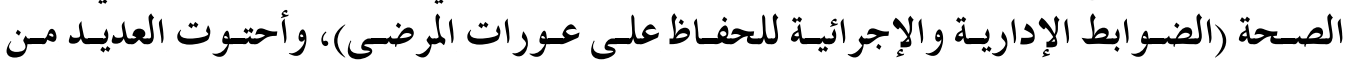




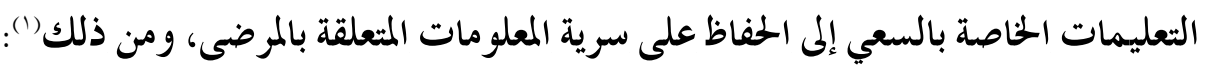

$$
\text { () يجب الخحافظة على الخحصوصية والسرية أثناء فحص المرضى. }
$$

Y ع على الفريق الطبي المعالج مناقشة الحالة الطبية للمريض مع الخحافظـة التامـة على خصو حسية

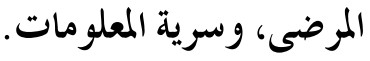

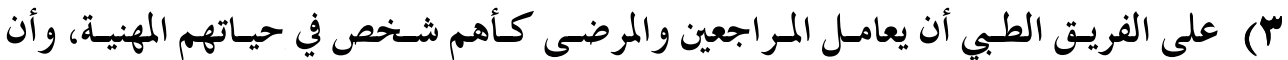

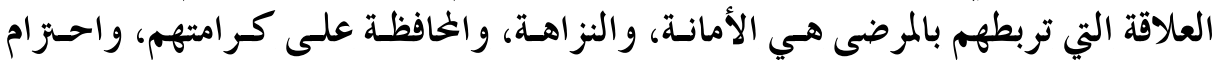

$$
\text { خصوصياتهم. }
$$

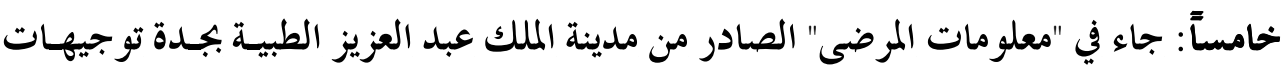

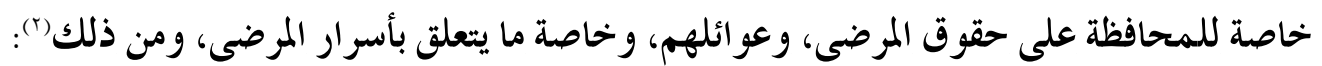

(1) عدم الطلب منه التحدث لأي شخص من غير الفريق المختص بتقديم الرعاية الصحية. Y) ع عدم السماح لغير الفريق المختص برعاية المريض الطبية من الاطلاع على ملفـه، وتفاصسيل

r) أن يتم فحصه وتقييمه في الأماكن المخصصة لذلك بعيداً عن مسمع ومرأى الآخرين. ع) أن تتم المعالجة والفحوصات بكل وقار وحشمة (أشعة، عملية، عيادة). •) أن ينقل إلى غرفة أخرى إذا تعرض للمضايقات مـن قبـل مرضسى أو زوار آخـرين حسـب السياسات المثبعة، وإمكانية توفر غرف أنرا أخرى.

ج) أن يعزل عن المرضى الآخرين لأسباب وقائية أو أمنية عند الضرورة حفاظاً على سلامتهم.

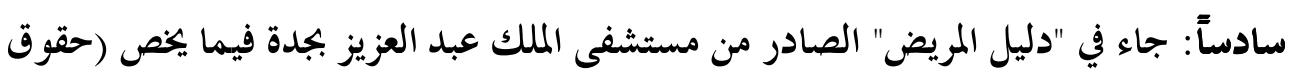

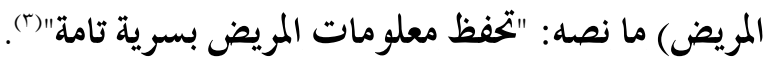

(1) ينظر : الضو ابط الإدارية والإجر ائية للحفاظ على عورات المرضى: إصدار / إدارة التوعية الدينية، المديرية العامة للشؤون

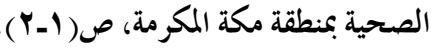

(Y) ينظر : معلومات المرضى: إصدار / مدينة الملك عبد العزيز الطبية بجدة، الشؤون الصحية بالحرس الوطني، ص(ه ( ـ ا ). (بّ) ينظر : دليل المريض: إصدار / مستشفى الملك عبد العزيز بجدة، مديرية الشؤون الصـحية بمحافظة جـدة، وزارة الصـحة

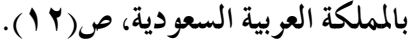


الحناتمة

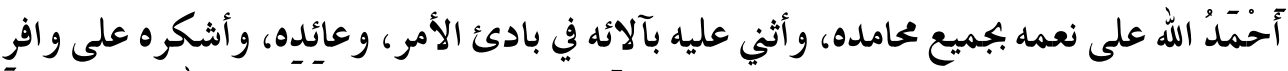

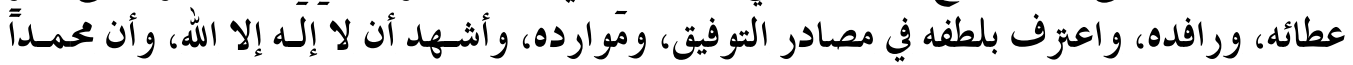

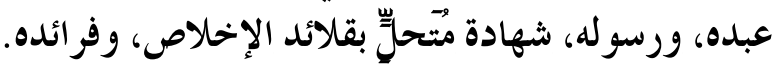

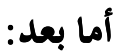

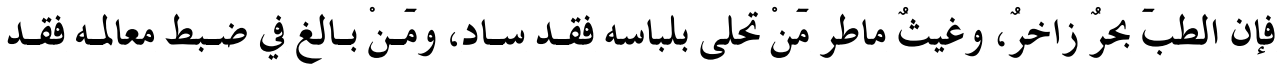

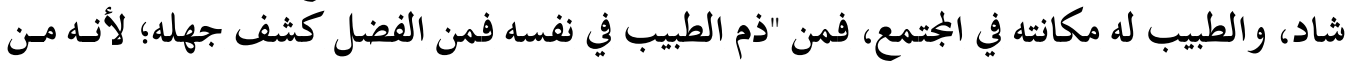

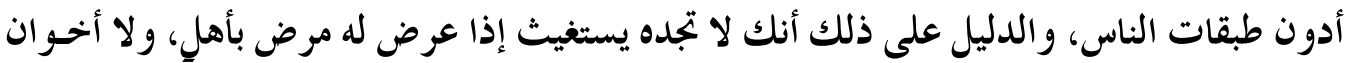

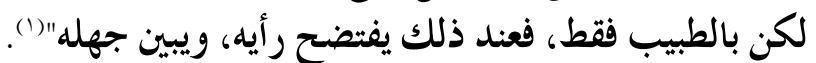

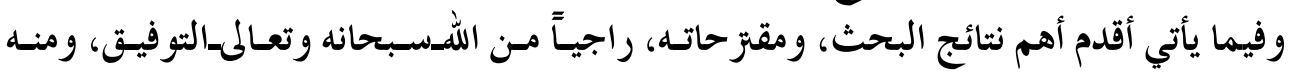

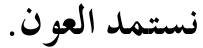
أولاً: النتائج.

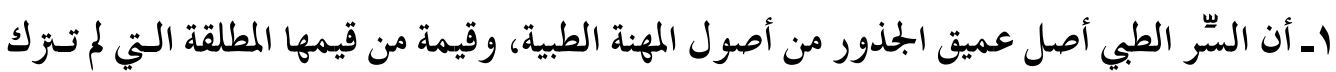

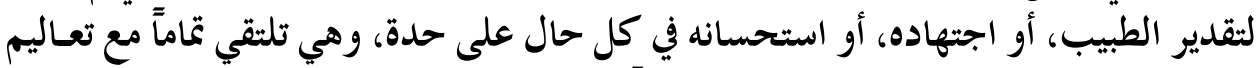

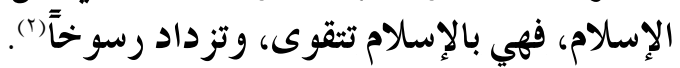

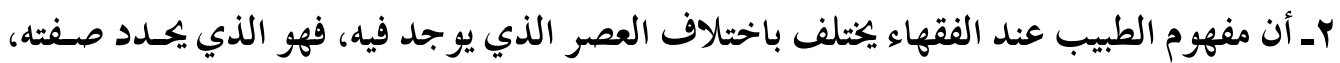

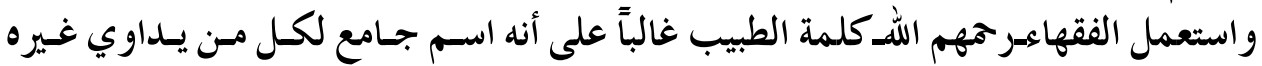

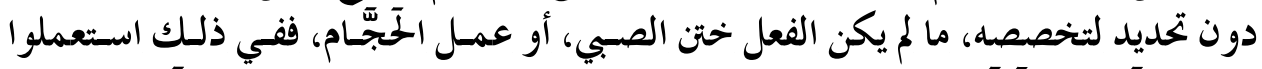

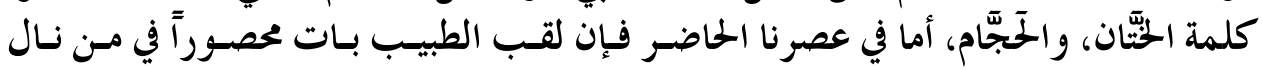

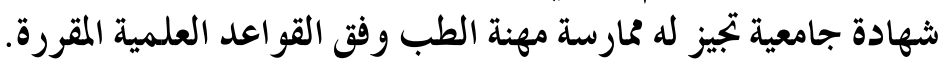

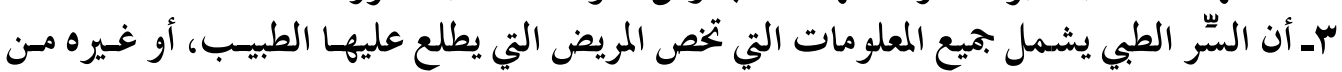

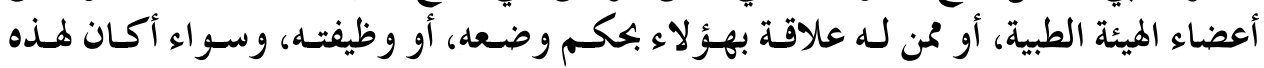

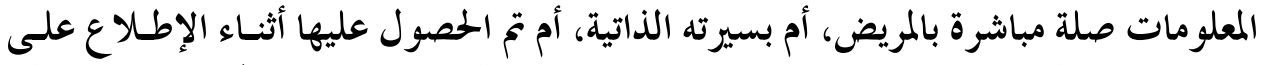

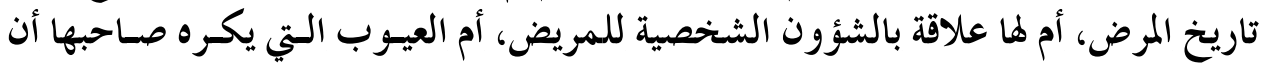
يطلع عليها الناس، أم عن علاقة ألمريض بالثرون بالآخرين.

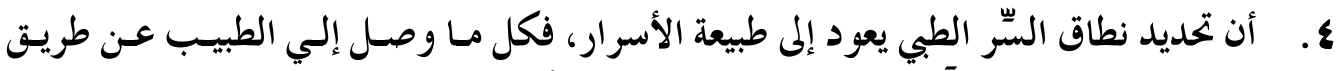

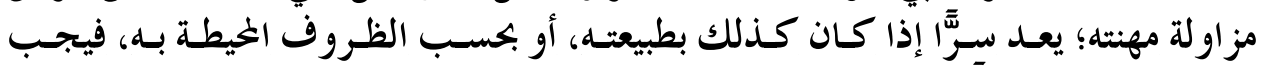

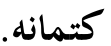

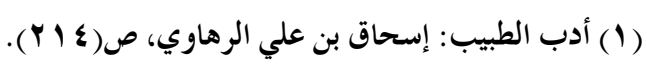

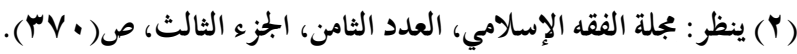




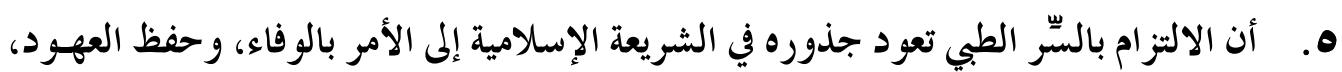

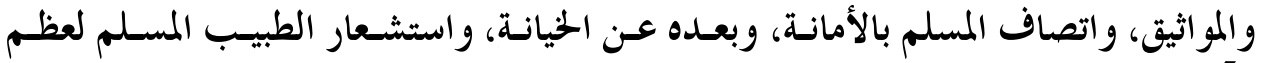

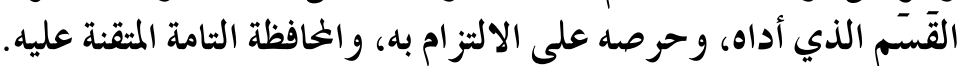
ج. الأصل حظر إفشاء السِّر، و إفشاؤه بدون مقتضِ معتبر موجب للمؤ اخذة شرعاً.

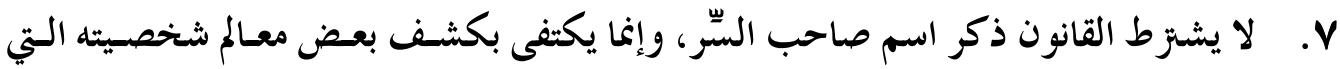

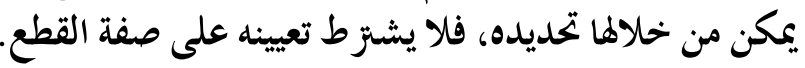

A. لا يباح إفشاء الطبيب للسر الطبي ولو لطبيب آخر؛ لأن المريض له فائدة ومصلحة معتبرة في

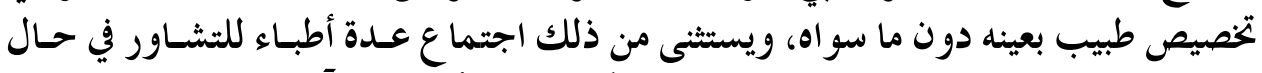

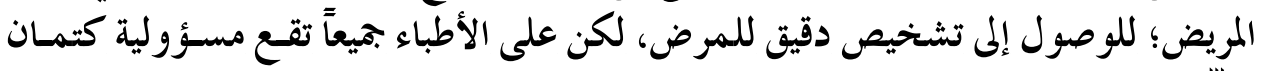

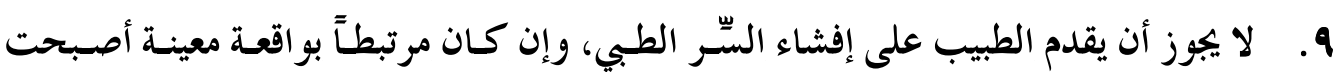

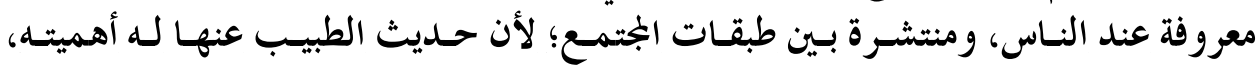
ومقداره، فالطبيب كالحاكم في المسألة.

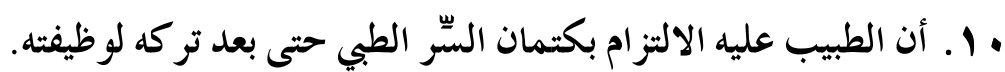

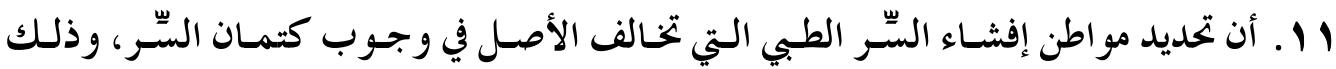

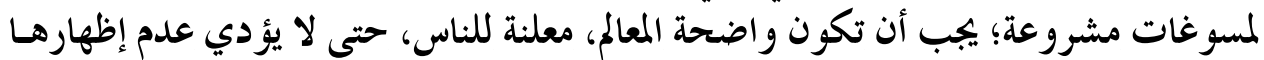

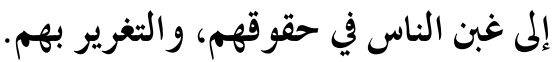

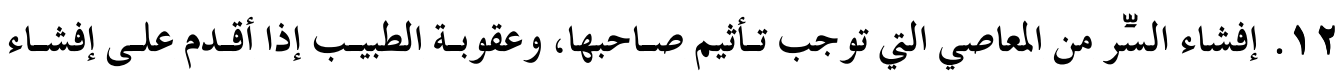
أسرار مرضاه من العقوبات التعزيرية.

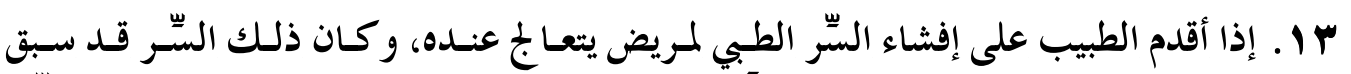

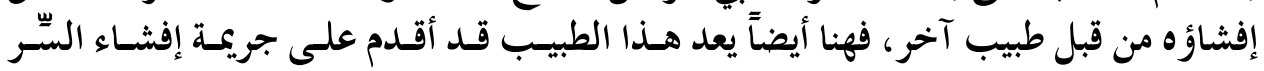

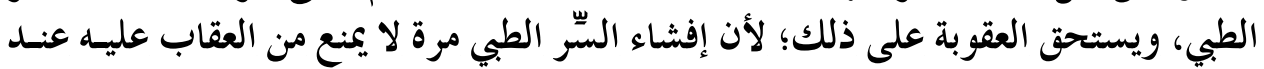

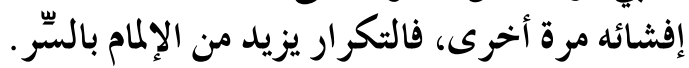

ع ا ـ لولي الأمر أو القاضي تغليظ العقوبة على الطبيب الذي يقع منه إفشـاء السِّر الطبي لجهـات متعددة.

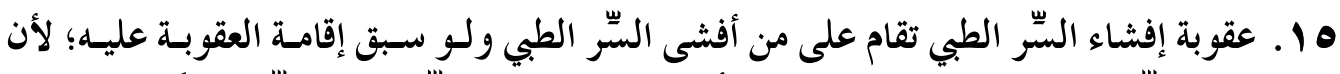

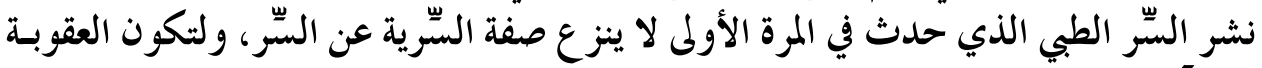
رادعاً له عن التمادي في هذا الذي حداث في المعل القبيح. 


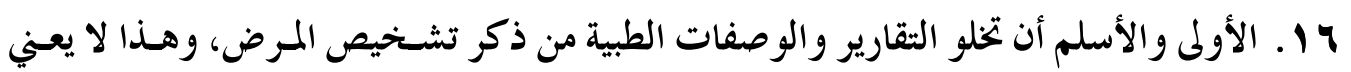

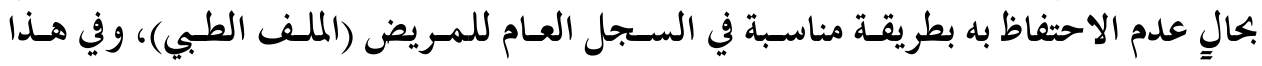

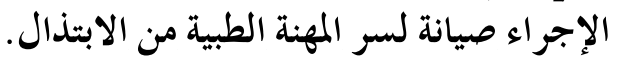

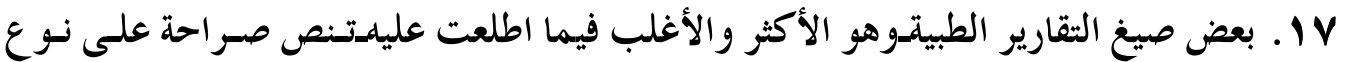

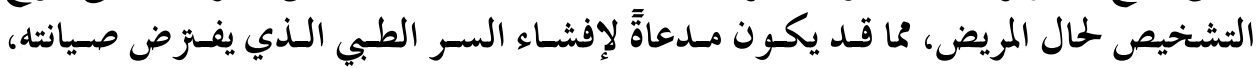

وحفظه، ويكرم إفشاؤه. ثانياً: المقتزحات.

ا - أن موضوع "سر المهنة" يستحق المزيد من الدراسة الجحادة، والبحـث العلمس، وأن يوجسه

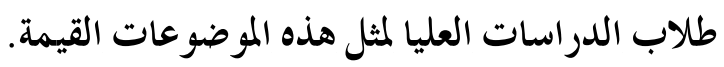

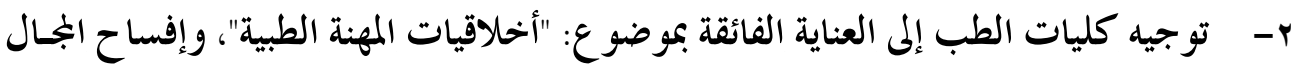

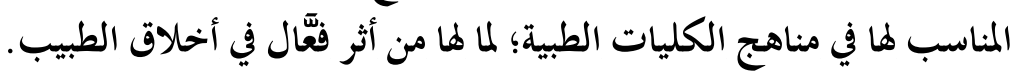

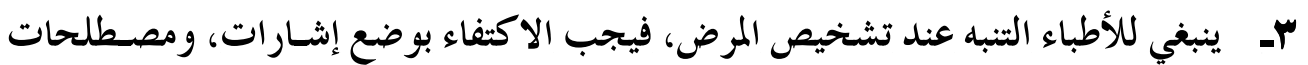

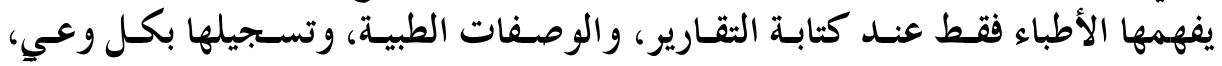

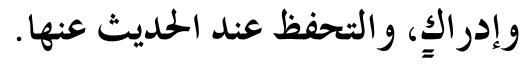

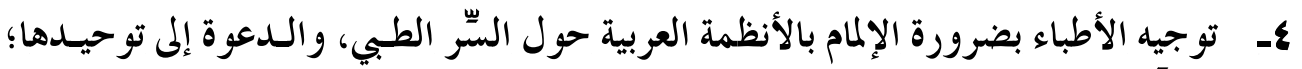
وفقاً لأحكام الشريعة الإسلامية.

•ـ التوجيه نحو إصدار النشر ات الخاصة، وتوعية الأطباء عن الأحكام الفقهية للسر الطبي.

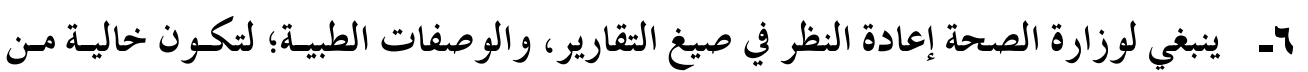

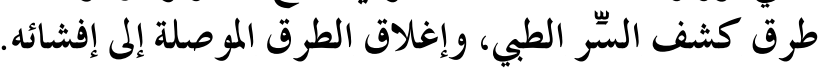

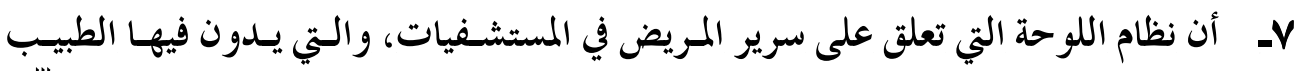

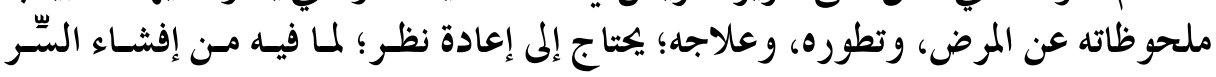
الطبي للعاملين، والزوار.

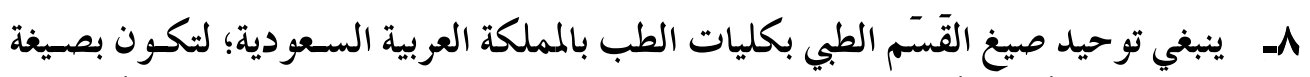

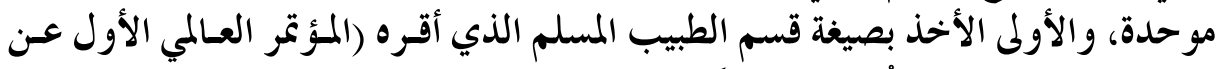

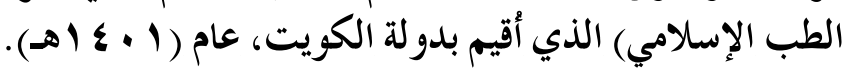
و آخر دعو انا أن الحمد لله الذي بنعمته تتم الصالحات. 


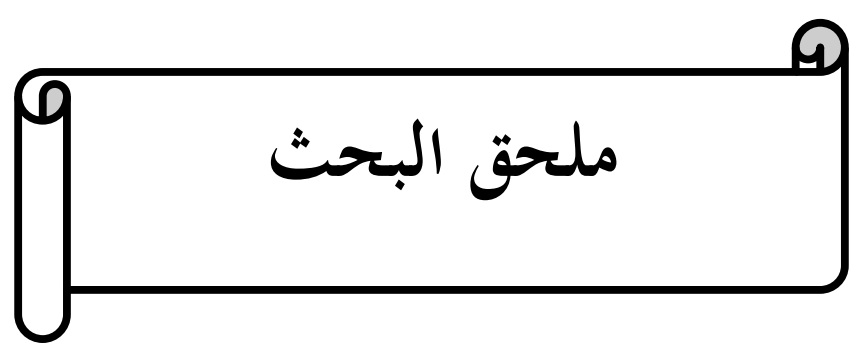

- 904 - 


\section{المملكة العربية السعودية

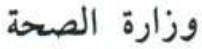

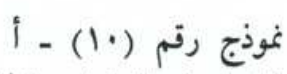

بشأن الوصفة الطبية في العيادات الخاصة والمجمعة

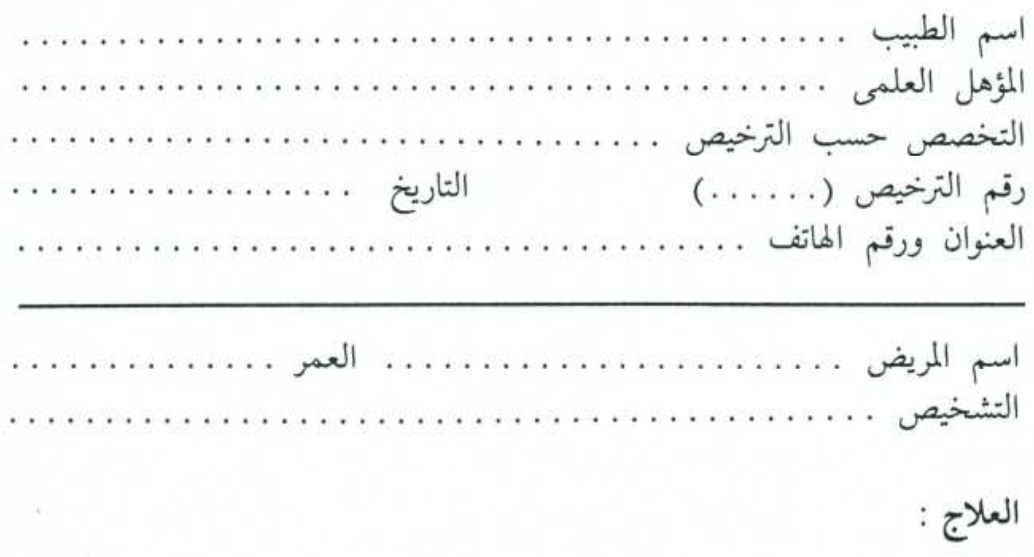

اسم الدواء وتركيزه وشكله الصيدلانى مقدار الجرعة

وعددها في اليوم ومواعيد تناولها ومدة العلاج بالأيام

توقيع الطبيب

المصدر :الالحة التنفيذة لنظام المؤسسات الطبية الخاصة ، ص بات

- 904 - 


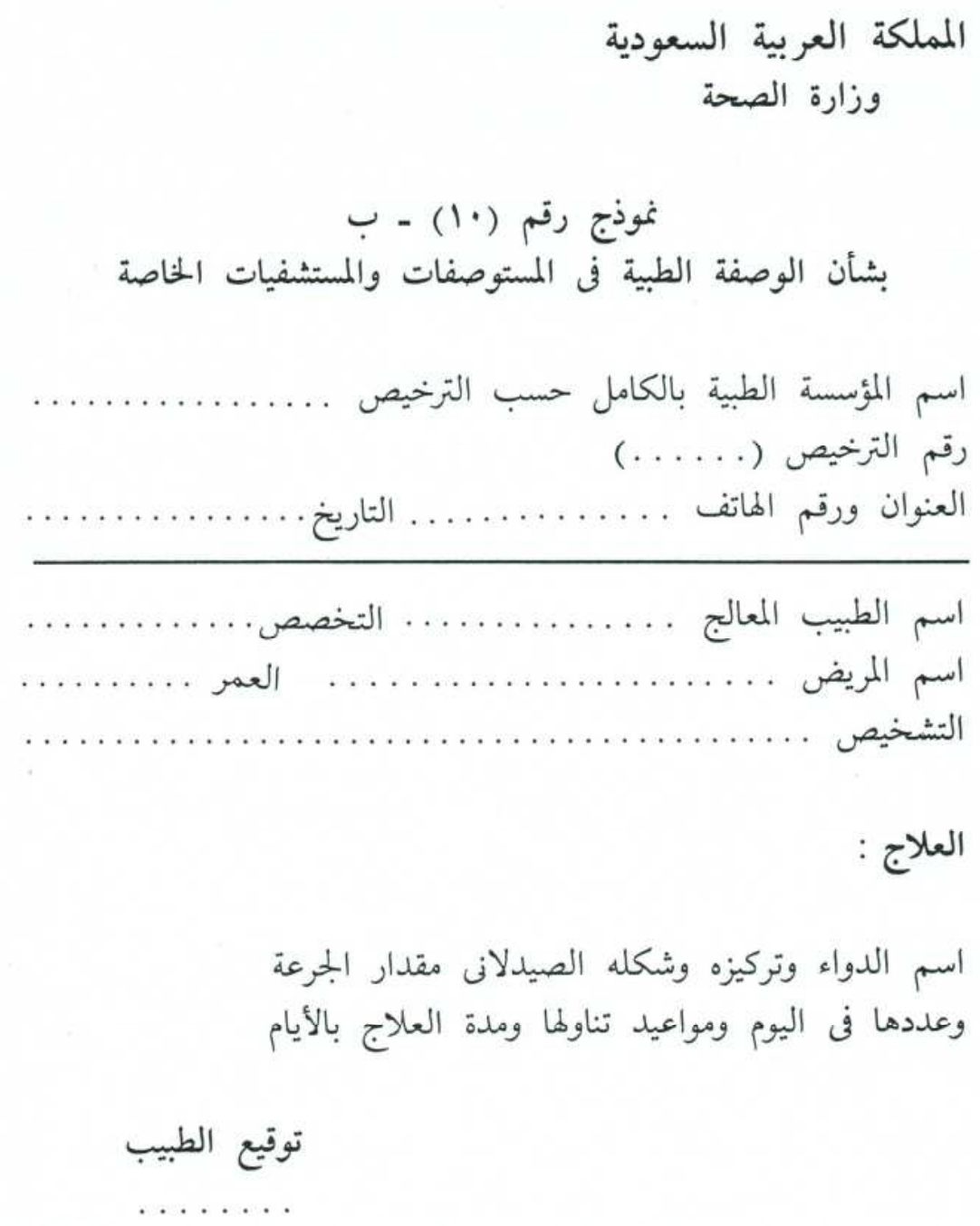

*قامندر :اللاتحة النففيذة لنظام المؤسسات الطبية الخاصة ، صع7.

$-90 \leq-$ 


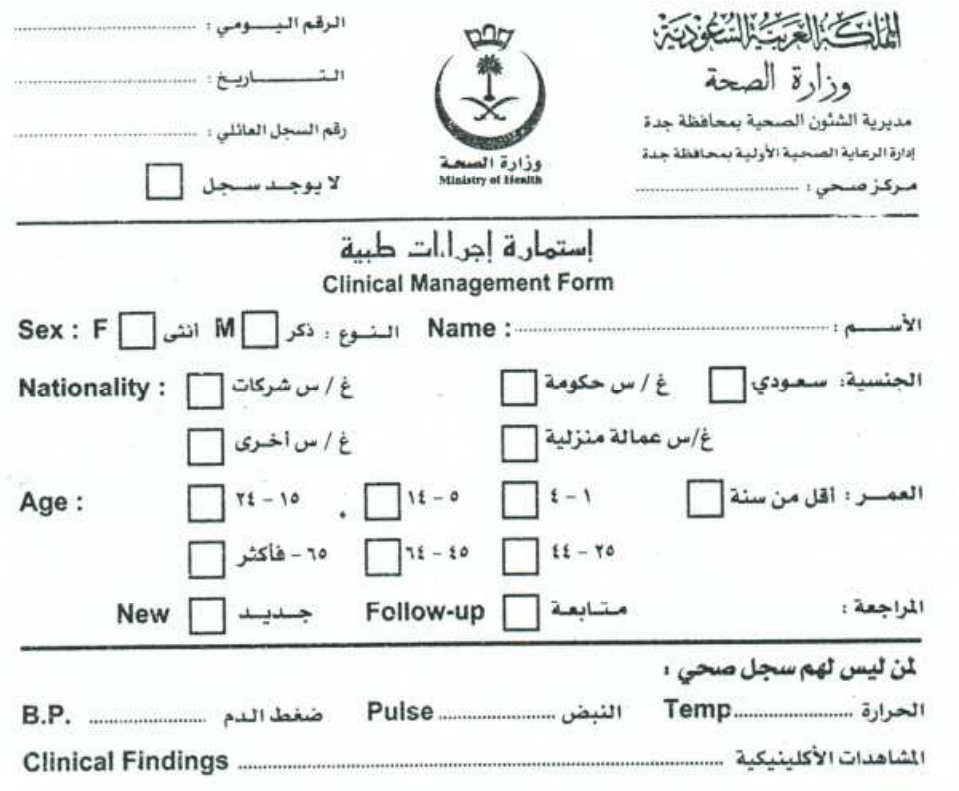
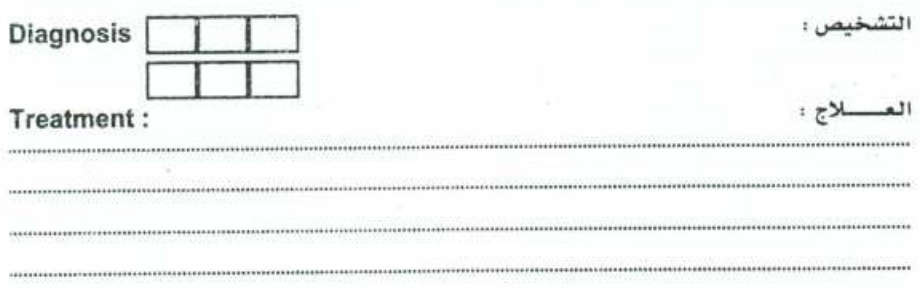

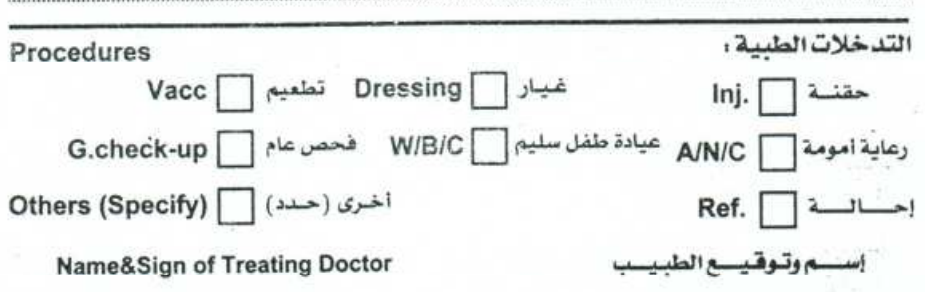



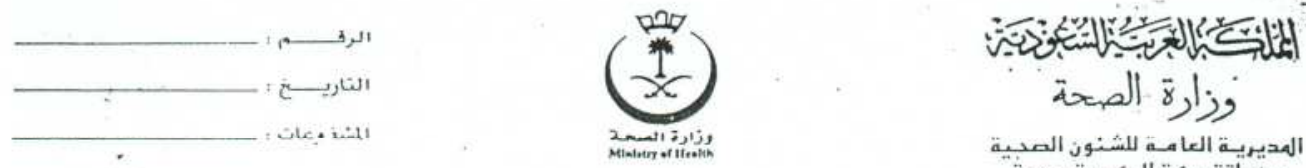

$$
\text { وزارة الصحة الصة }
$$

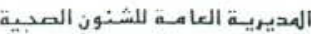
بنطقة عكة الهكرة هة - بدة الهة

$$
\text { ver is }
$$

Paticnt Name

Medical Record No:

Nationality:

$$
\square M
$$

M $\square$ :

\section{F}

$$
\text { انثى }
$$

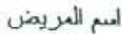

Date of Birth :

Occupation :

Place of Work :

Date of Visit:

Adm Date :

Discharge Datc :

$$
-x
$$

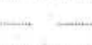

$-\cdots$

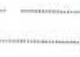

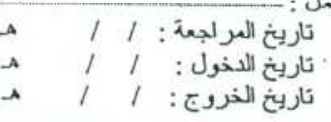

Recommendation

Followine medical cxamination: it is recommended

$\square$ Sick leave for day(s)

Starting Fron

الترصبات

$\square$ Follow up before end of sick lcave

$\square$ Referral to Medical Committec for

$\square$ following reasons :

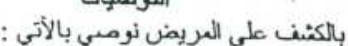

- Approval of sick lcave

$\square$ Cannot be treated at this facility

$\square$ Permanent or vartial disability $\square$ Others

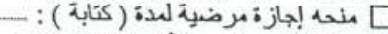

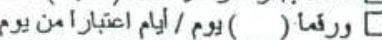

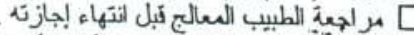

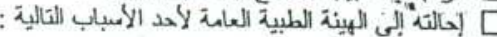

.

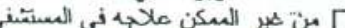

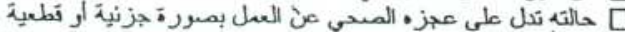

Treating Physician Name:

Signature : -...... Badge No:

Physician Name :

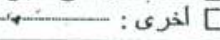

Signature

Approved by the Dircctor of

Name :

Signature :

Ditc :

الختبم الر سبهي
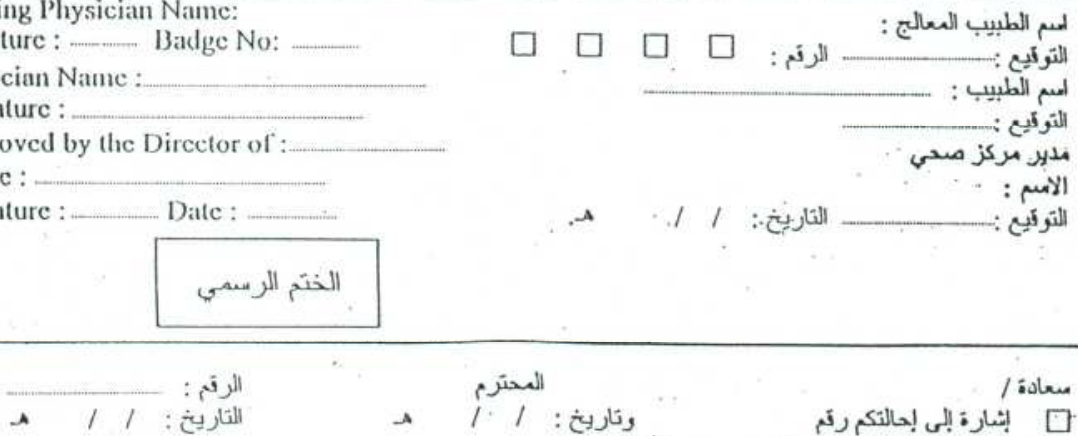

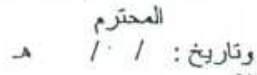

/ مساد

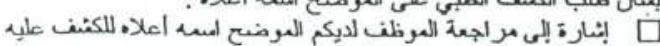

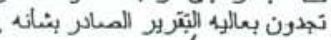

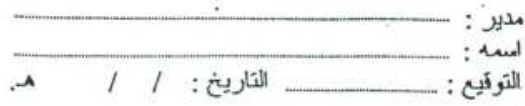




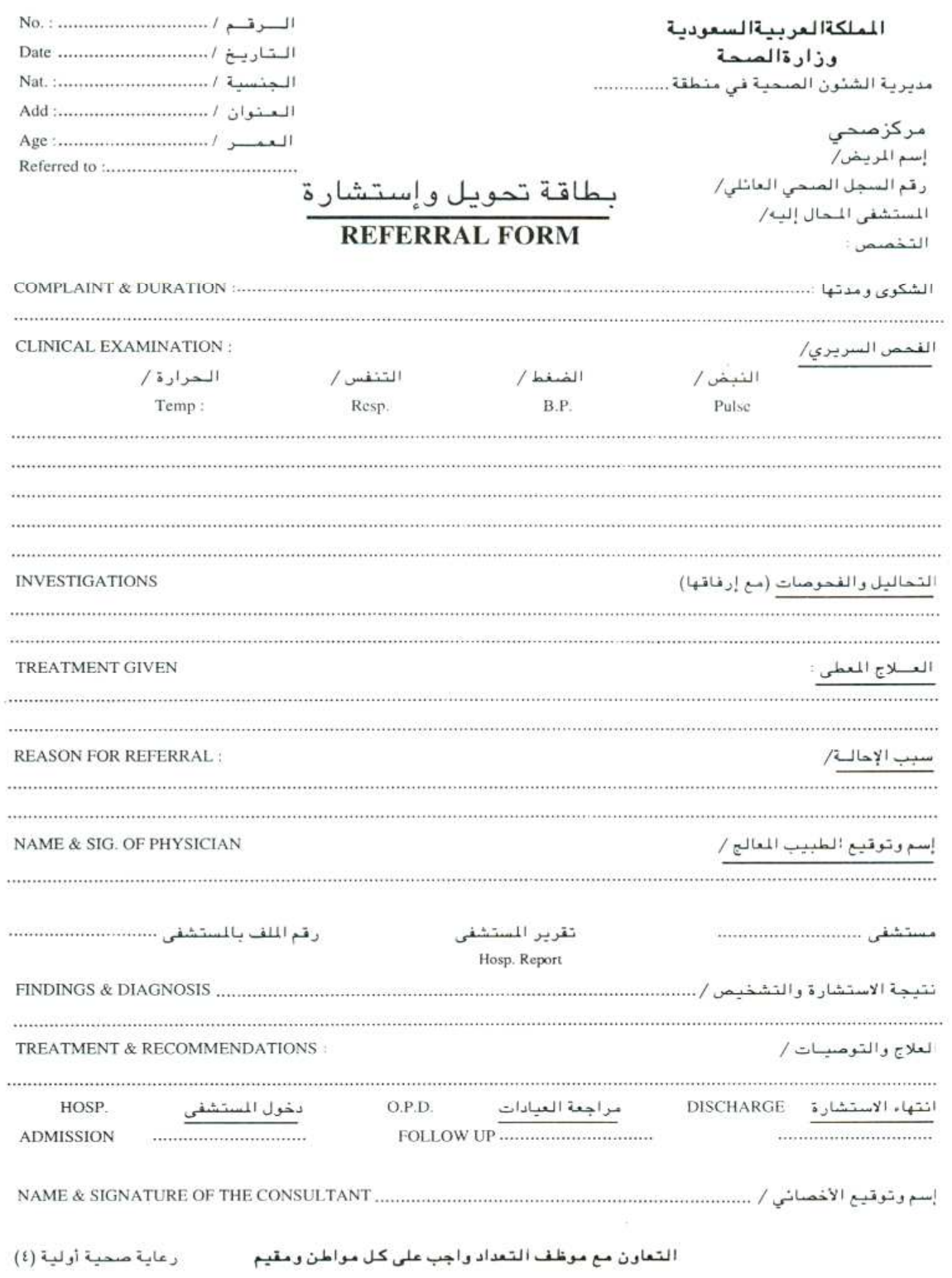




\section{المملكة العربية السعودية}

وزارة الصحة

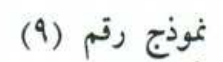

بشأن سجل المرضى رقل

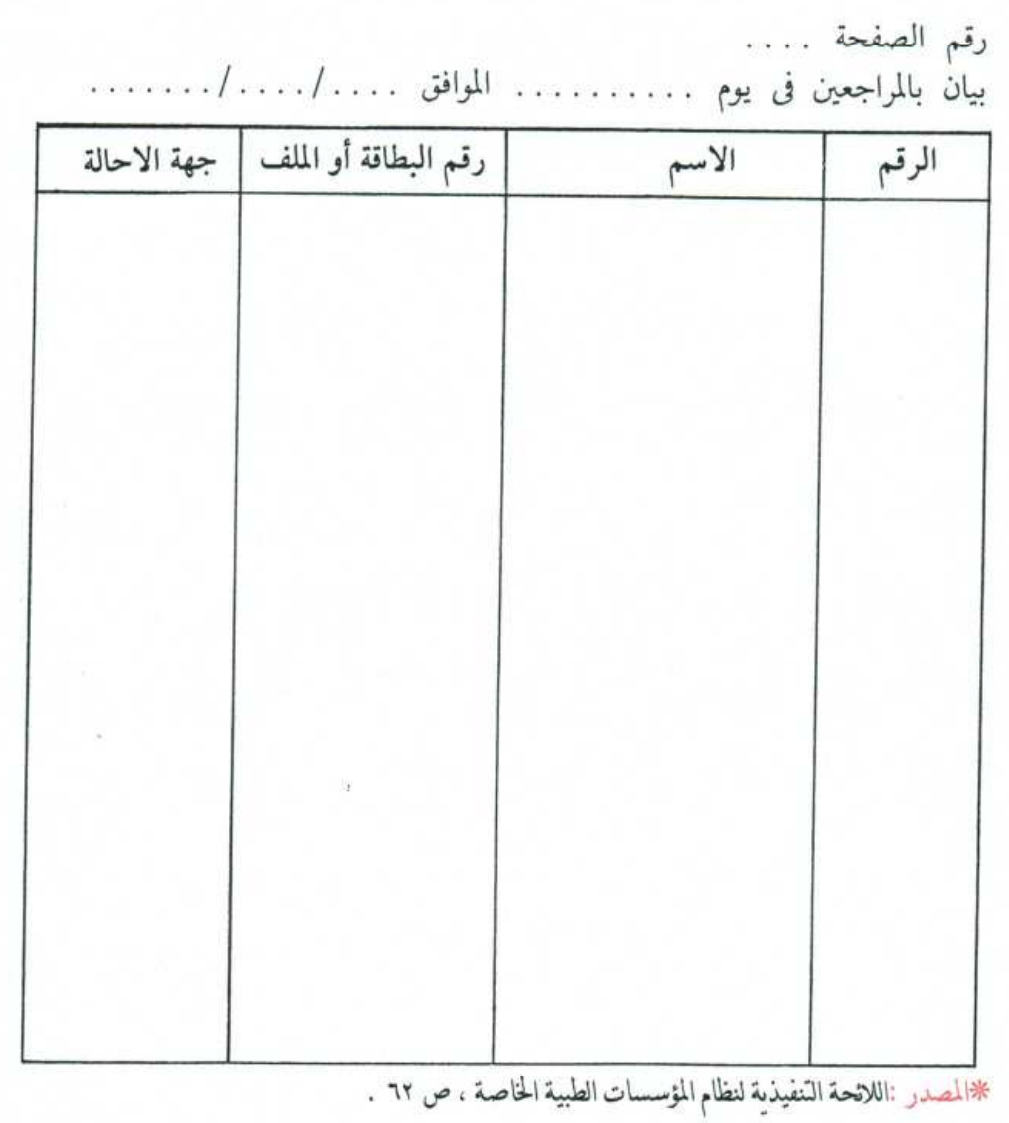

$-901$. 


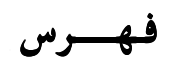

المصـادر والمراجــع

"أولاً: الرسائل الجامعية.

ا. التعبير عن الرأي ضوابطه وبجالاته في الثريعة الإسلامية دراسة فقهية تأصيلية: إعداد:

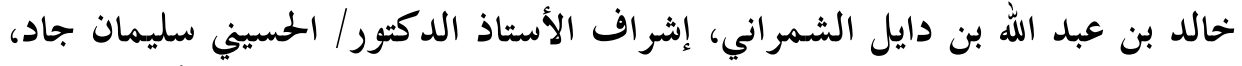

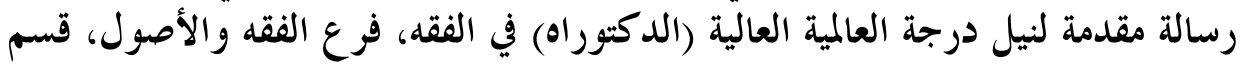

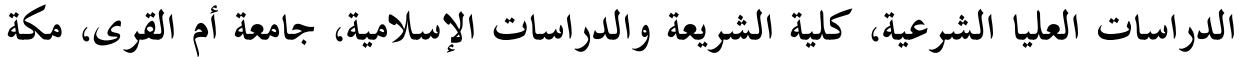

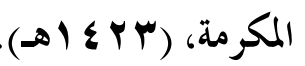

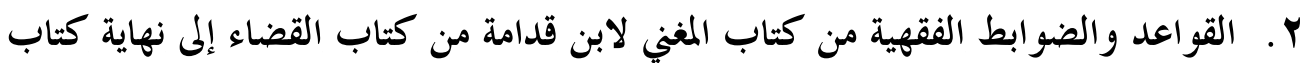

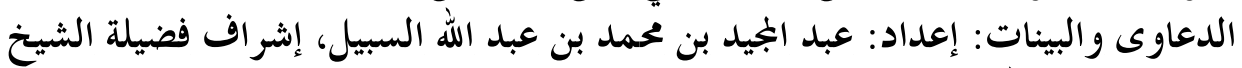

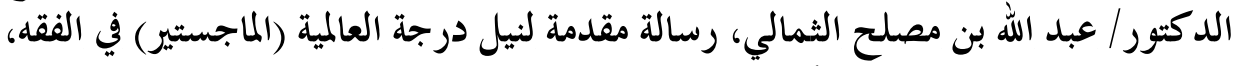

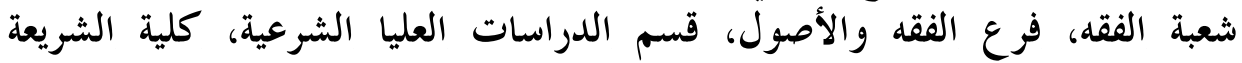

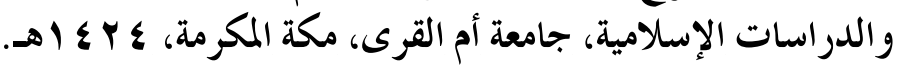

$$
\text { ثانياً: الكتب المطبوعة. }
$$

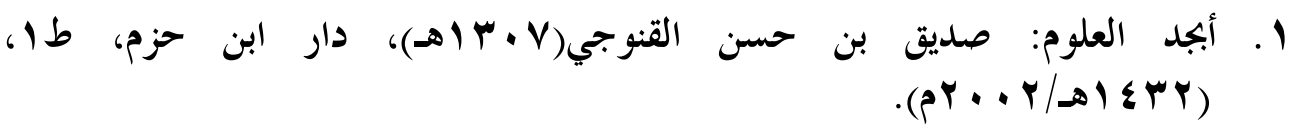

Y. . أبحاث اجتهادية في الفقه الطبي: د.محمد سليمان الأشقر، مؤسسة الرسالة، بيروت، ط ال،

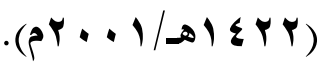

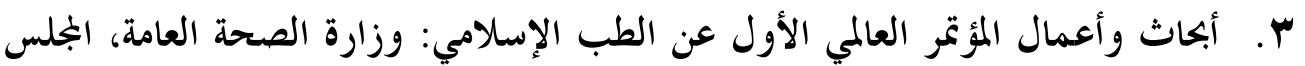

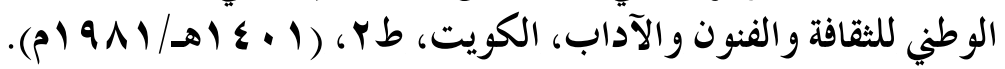

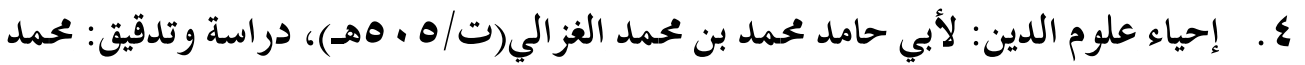

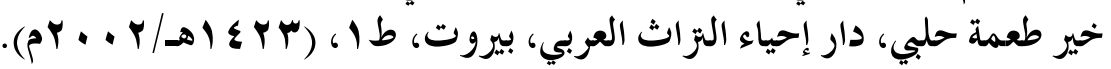
ه. أخلاقيات الطبيب المسلم: د.سعد الشثري، ضمن"الرسائل المختصرة" اختيار وإعداد:

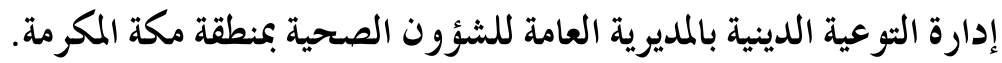

ج. الآداب الشرعية: لأبي عبدالله محمد بن مفلح المقدسي ( ت بآلهـ )، تحقيق: شعيب 
الأرناؤوط، عمر القيام، مؤسسة الرسالة، بيروت، طب، (9 (1 الهـ/9 9 9 (م).

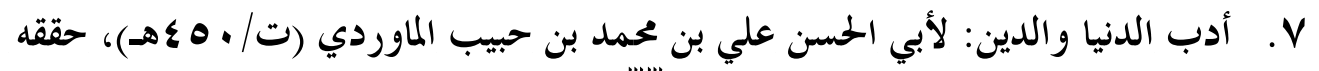

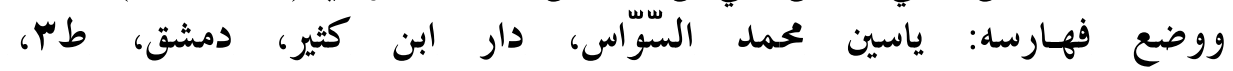

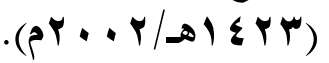

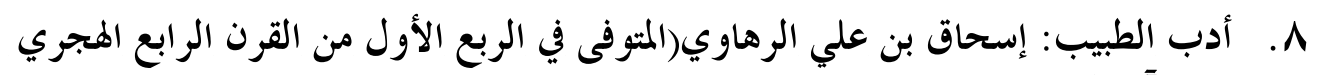

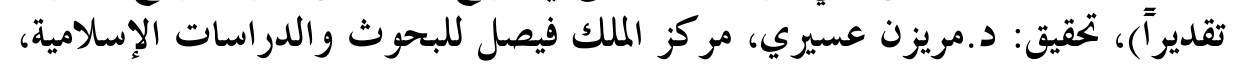

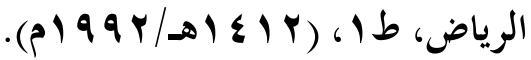

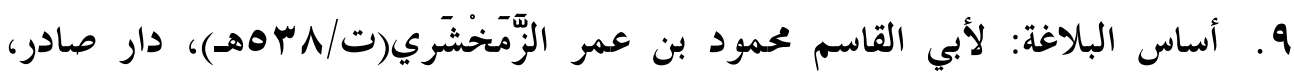

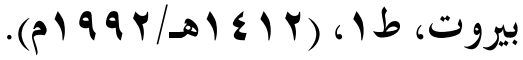

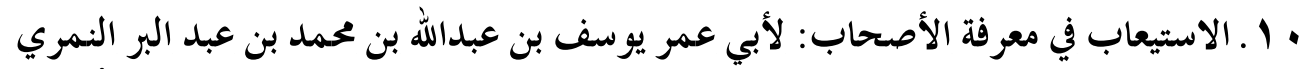

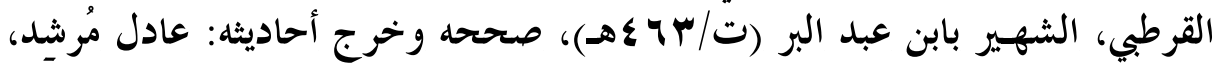

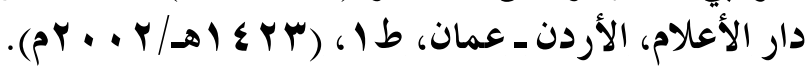

1 ا ـ أسد الغابة في معرفة الصحابة: عز الدين أبو الحسين علي بن محمد الجزري، الثهير بابن

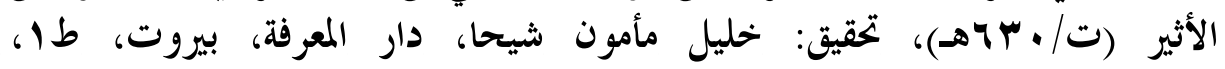

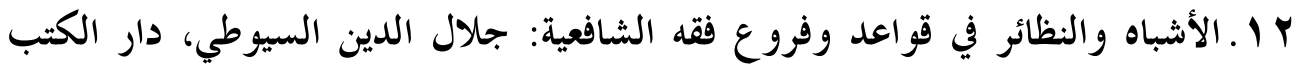

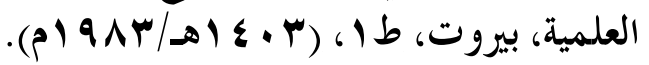

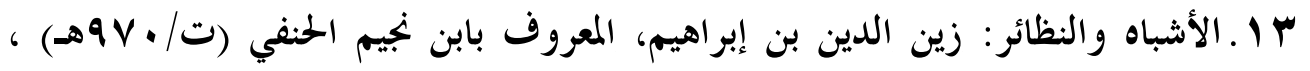

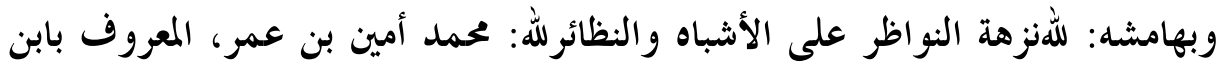

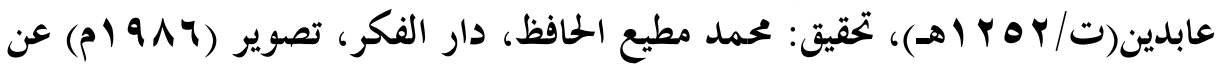

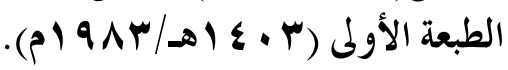

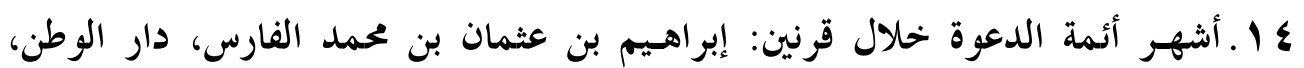

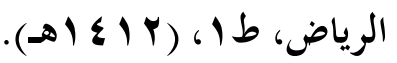

ه 1 الإصابة في تمييز الصحابة: أحمد بن علي بن علي بن محمد العسقلاني، الثهير بابن حجر

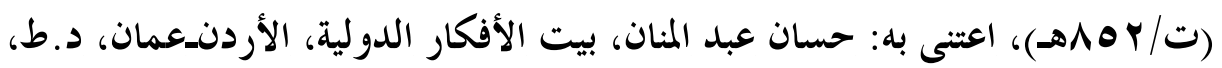


7 ا ـ الاعتصام: لأبي إسحاق إبراهيم بن موسى بن محمد اللخمي الشاطبي (ت / . 9Vهـ)،

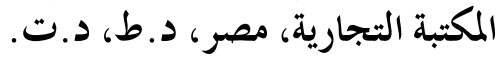

1V اعتنى بها: مكتب التحقيق بلدار إحياء التزاث العربي، بيروت، طال،

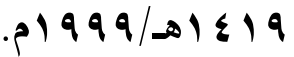

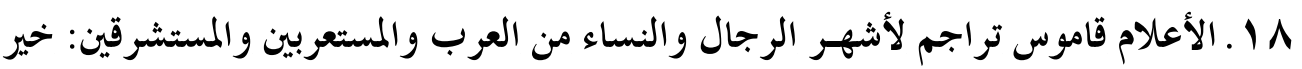

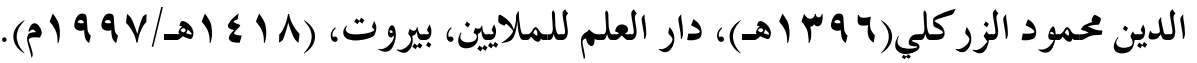

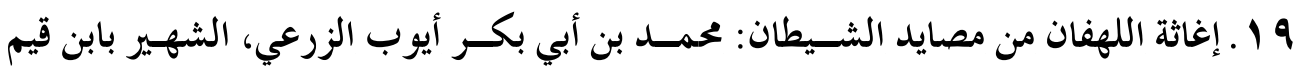

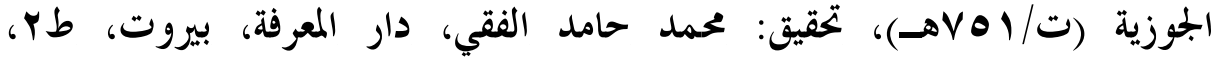

. 9 190/ه

• ץ. إفشاء الأسرار وأحكامه في الفقه الإسلامي: محمد بن احمد واصل، دار طيبة، الرياض،

$$
\text { طا ( }
$$

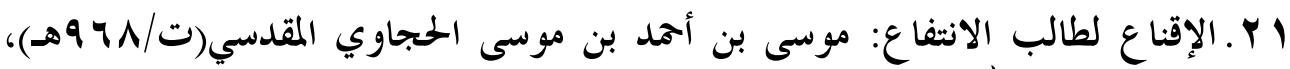

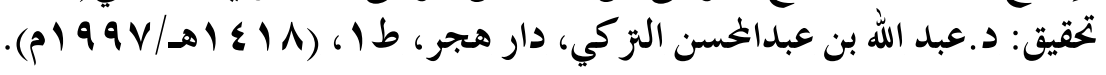

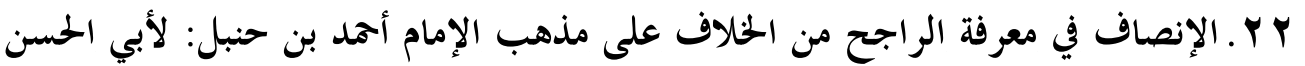

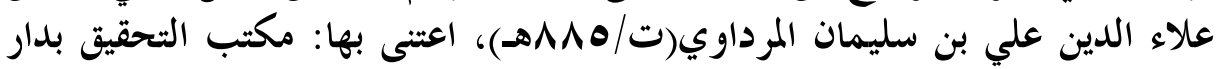

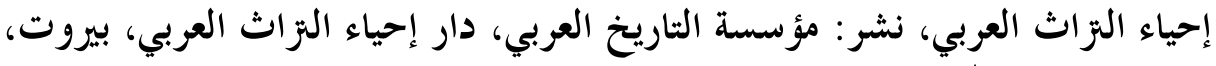

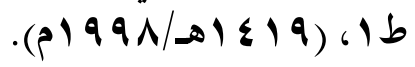

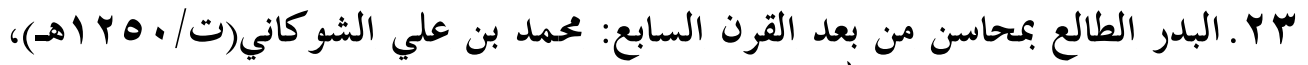

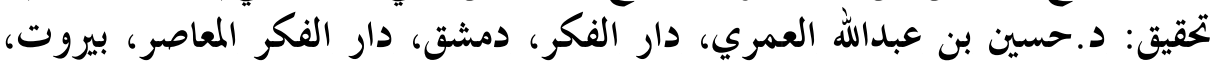

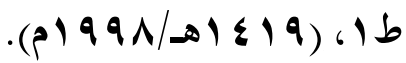

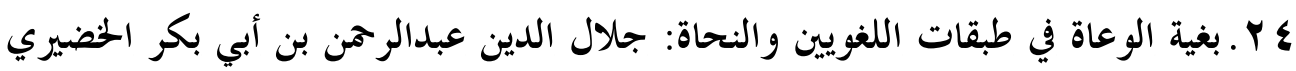

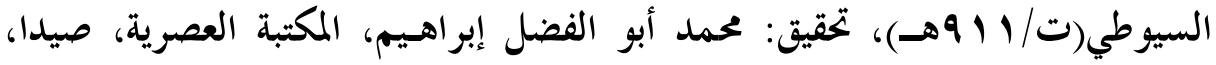

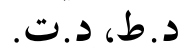

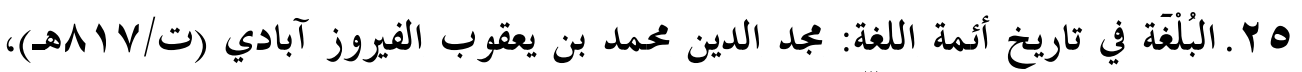

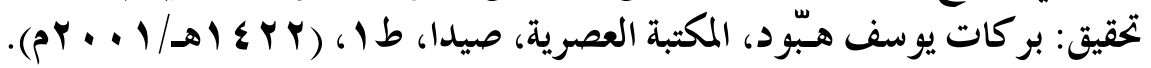

جr. تاج اللغة وصحاح العربية، الثهير"الصحاح": لأبي نصر إسماعيل بن حماد الجوهري

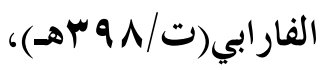




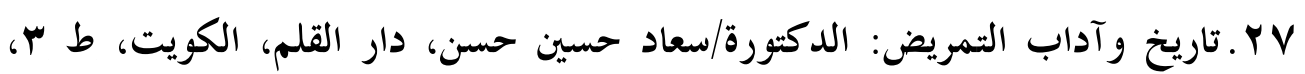

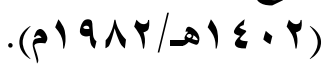

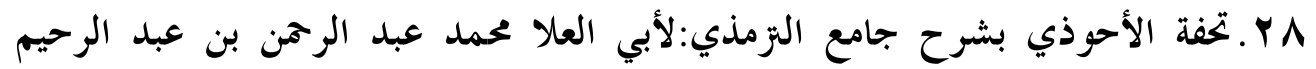

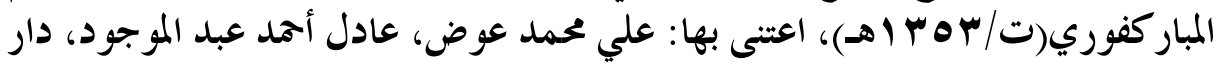

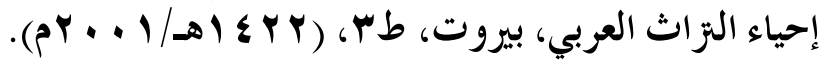

q Y. الثداوي والمسئولية الطبية في الثريعة الإسلامية: د.قيس بن محمد آل الثيخ مبارك،

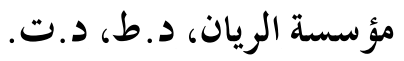

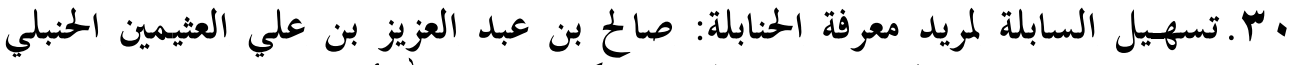

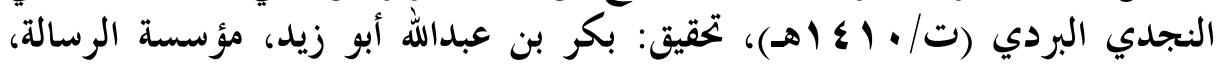

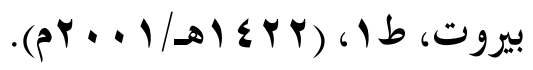

اس. التشريع الجنائي الإسلامي مقارناً بالقانون الوضعي: عبد القادر عودة، مؤسسة الرسالة،

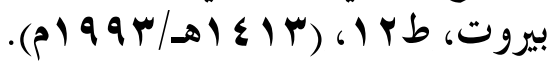

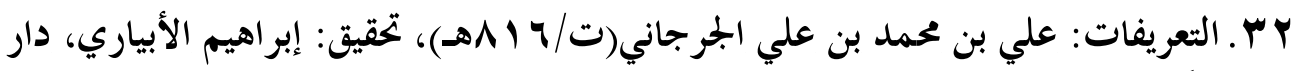

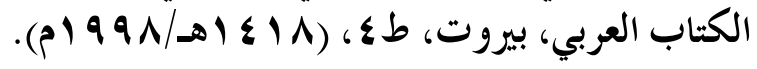

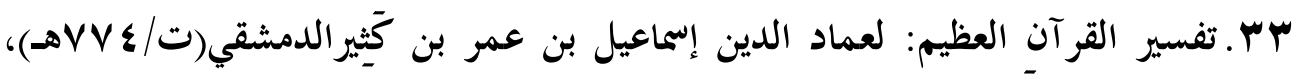

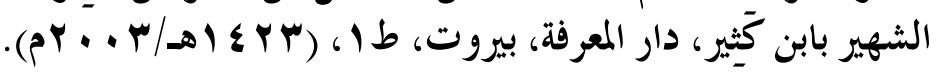

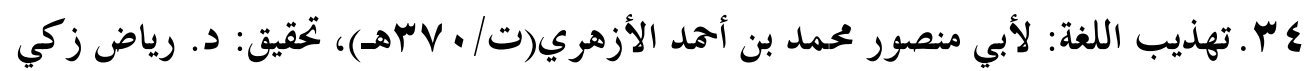

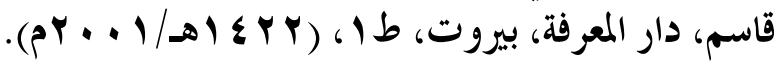

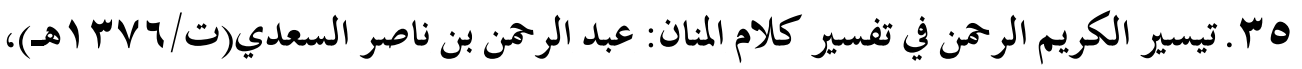

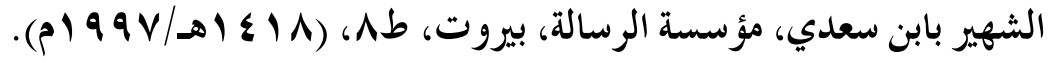

צץ. جامع التزمذي، الثهير بـ"سنن التزمذي": لأبي عيسى عحمد بن عيسى بن سورة

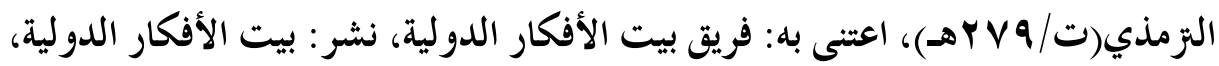

$$
\text { د.ط، د.ت. }
$$

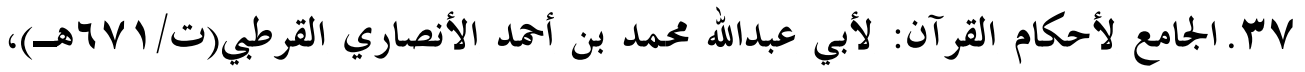

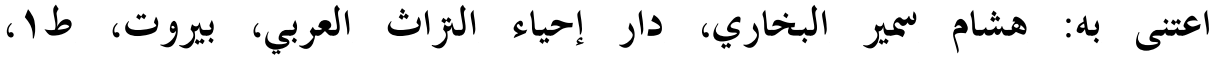




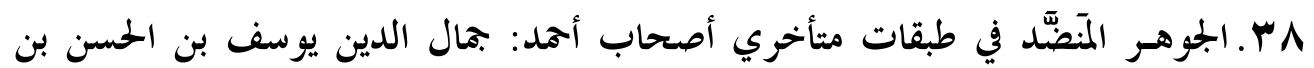

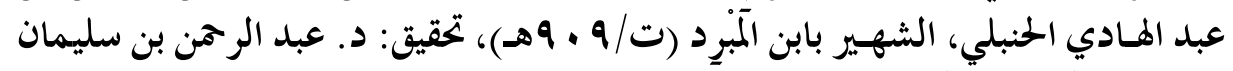

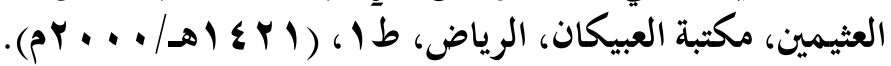

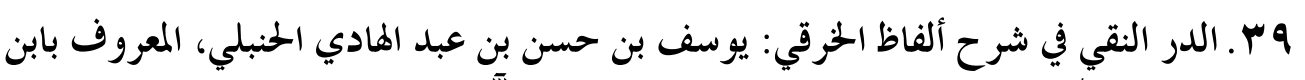

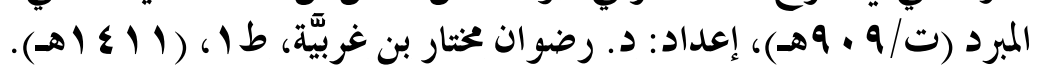

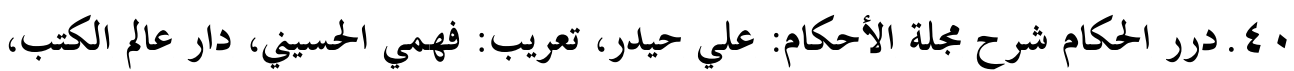

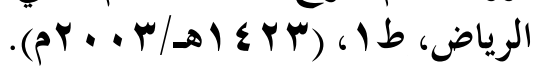

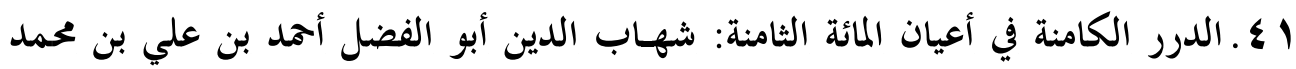

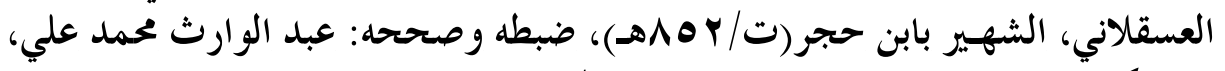

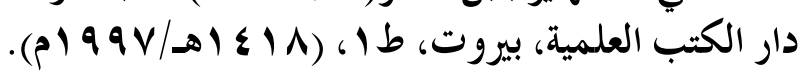

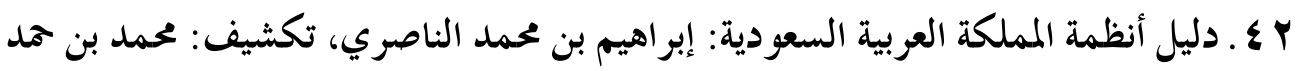

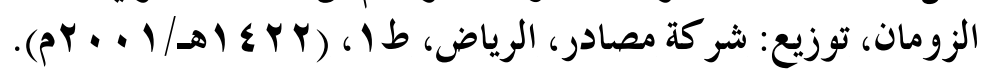

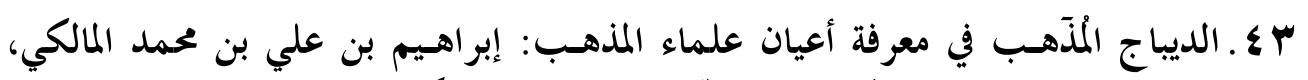

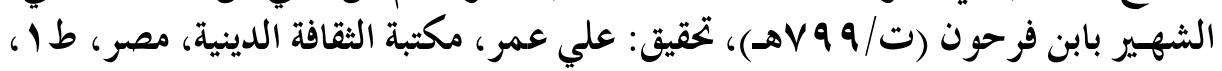

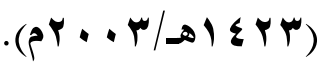

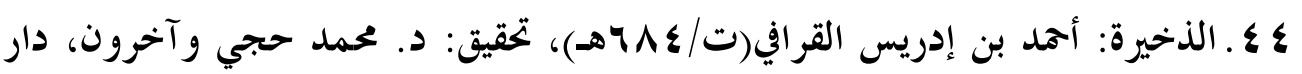

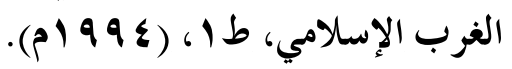

هـ ـ الذيل على طبقات الحنابلة: لأبي الفرج زين الدين عبد الرحمن بن أحمد بن عبد الرحمن الرحن

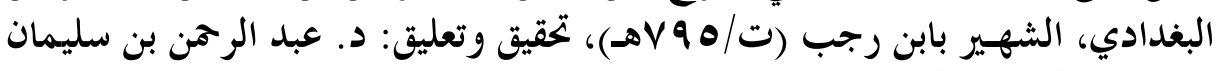

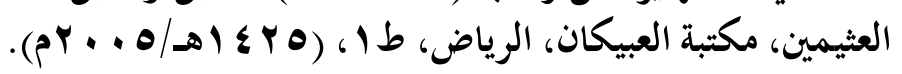

ج \ـ الرؤية الإسلامية لبعض الممارسات الطبية: مطبوعات المنظمة الإسلامية للعلوم الطبية،

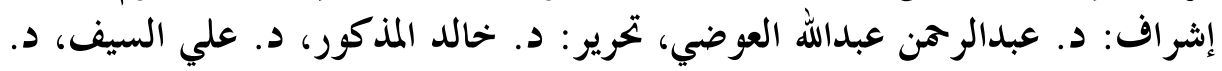

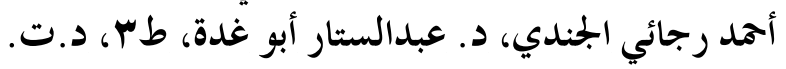

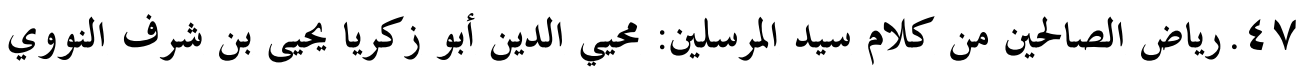

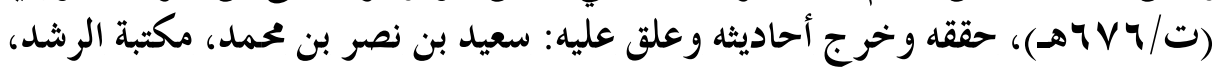

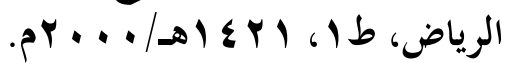


^§. زاد المعاد في هدي خير العباد: لأبي عبد الله محمد بن أبي بكر الزرعي الدمشقي

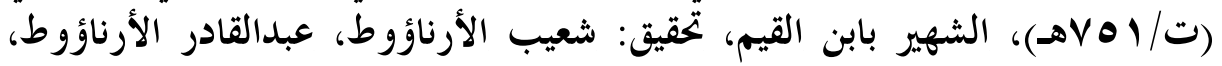

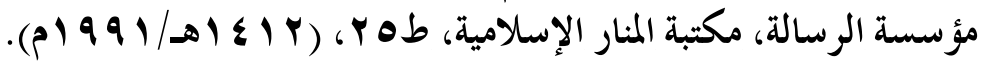

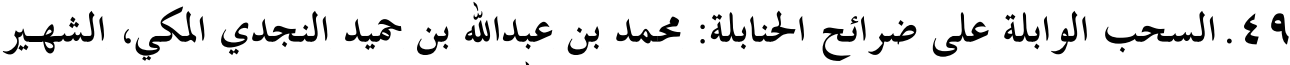

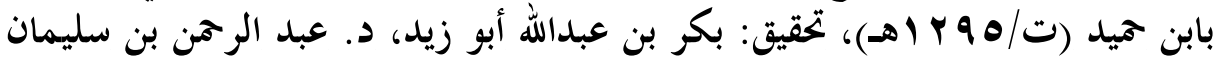

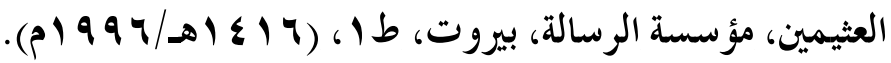

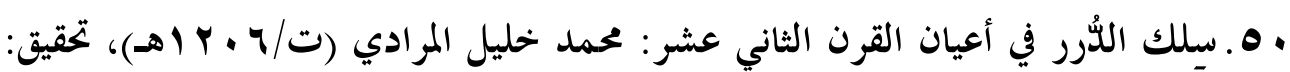

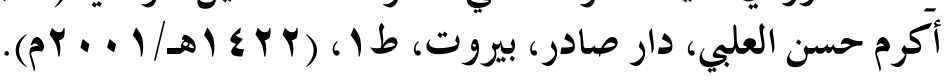

10. السلوك المهني للأطباء: د. راجي عباس التكريتي، دار الأندلس، طץ،

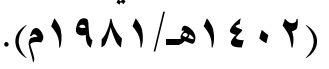

ro

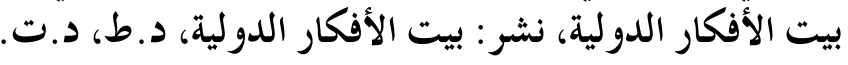

به. السنن الكبرى: لأبي بكر أحد بن الحسين بن علي البيهقي(ت/Nهـهـ)، وبذيله "الجوهر النقي" للمارديني، دار المعرفة، طا ، (ب أع اهـ).

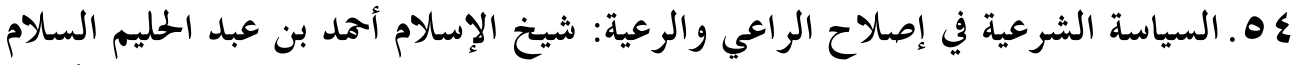

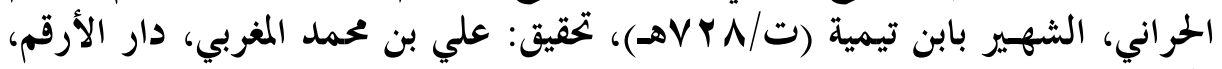

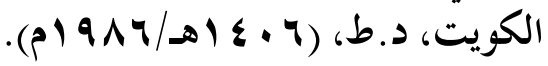

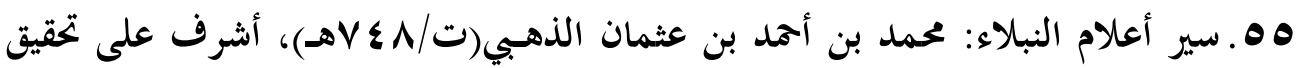

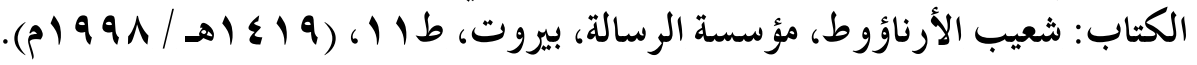

7ه شجرة النور الز كية في طبقات المالكية: محمد بن محمد مخلوف(ت/ / ـ ا اهـ)، دار الفكر،

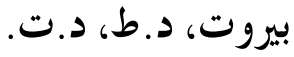

هـ هذرات الذهـب في أخبار من ذهـب: شهاب الدين عبدالحي بن أحمد بن محمد العكري

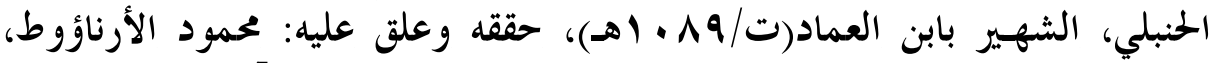

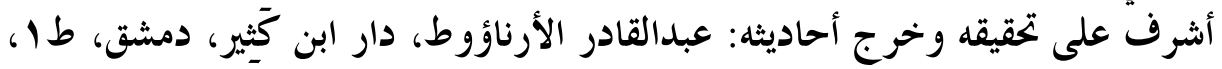

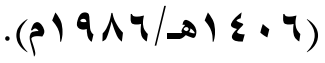

^هـ شعب الإيمان: لأبي بكر أحد بن الحسين بن علي البيهقي(ت/ON عــ)، تحقيق: محمد 
السعيد بسيوني زغلول، دار الكتب العلمية، بيروت، طا، ( • (1 (هـ).

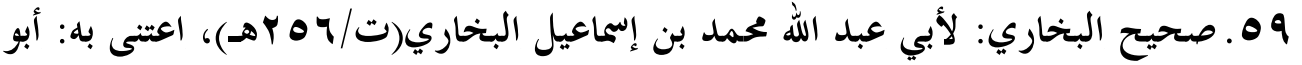

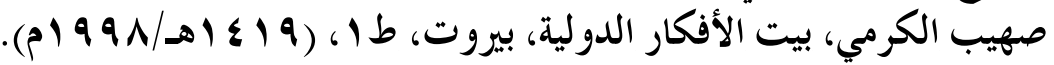

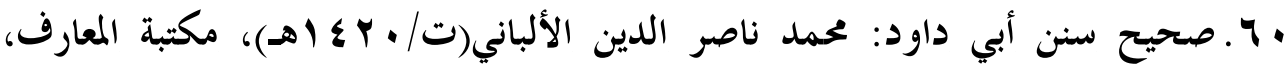

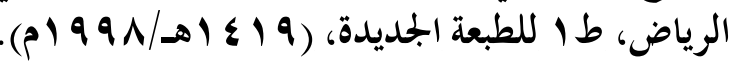

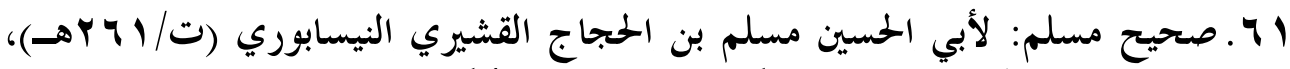

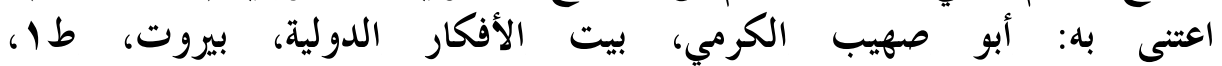
(م) (99人/ه1 (19)

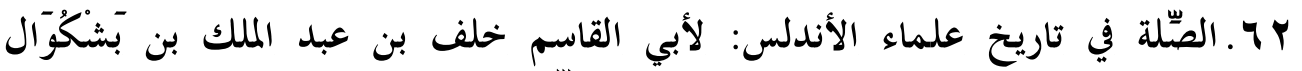

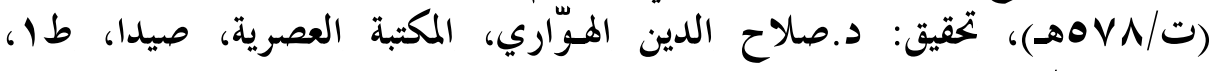

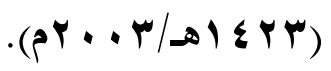

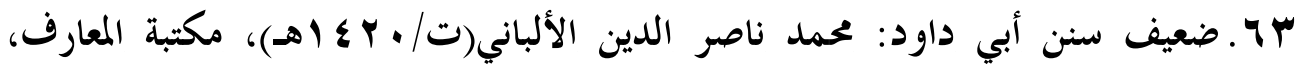

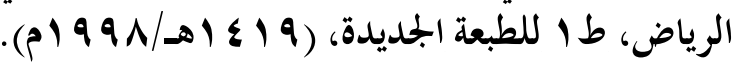

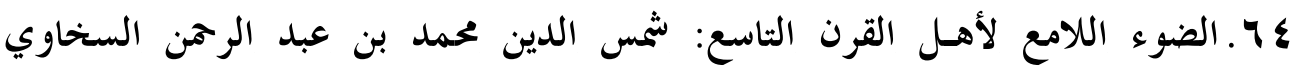

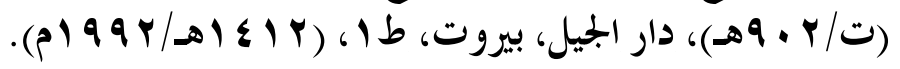

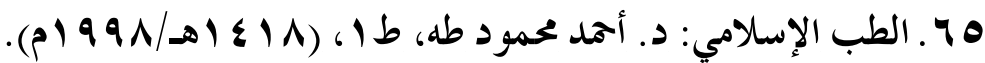

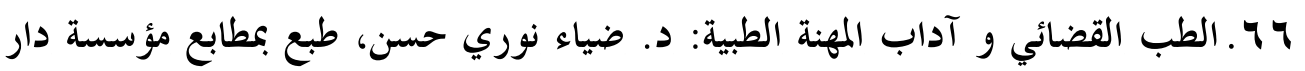

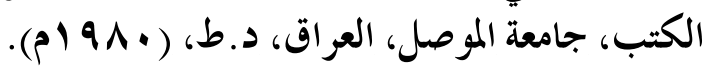

V7. الطب ورائداته المسلمات: د.عبدالله عبدالزازاق مسعود السعيد، مكتبة المنار، الأردن،

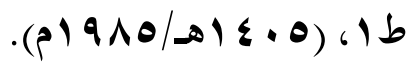

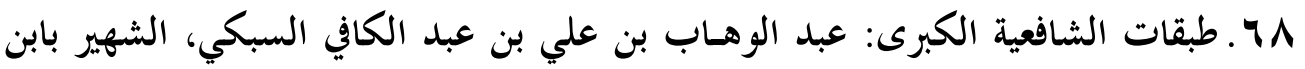

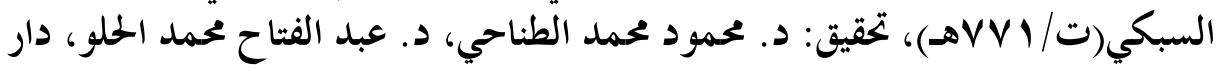

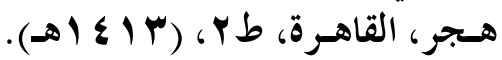

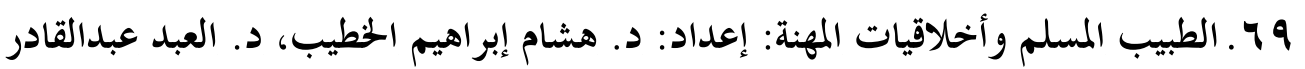

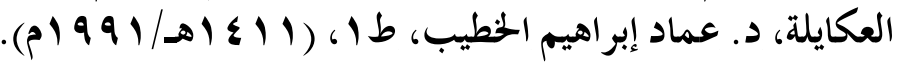




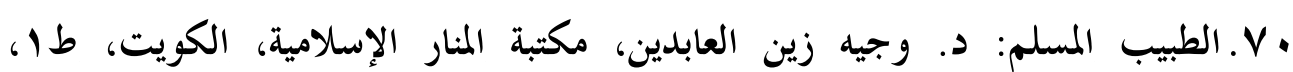
.( () $9 \Lambda V / \Delta) \varepsilon \cdot V)$

ا. V. الطريقة الخمدية: محمد بن بير علي البر كلي، تحقيق: أ.د//حممود حسن أبو ناجي الشيباني،

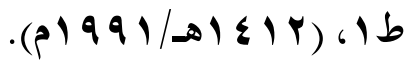

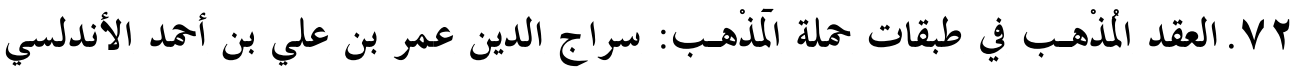

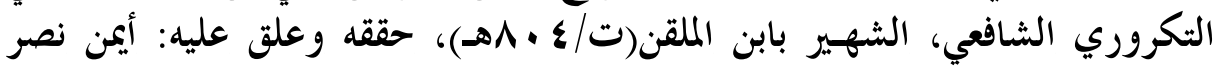

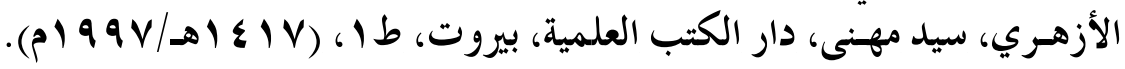

ب.V. العقوبة في الفقه الإسلامي: أحمد فتحي بهـسي، دار الرائد العربي، القاهرة، طY،

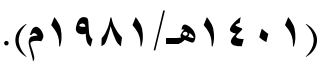

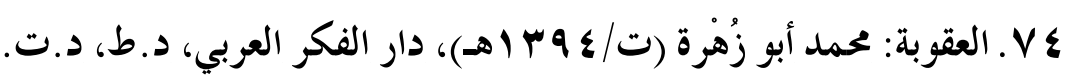
ه V. علماء نجد خلال ثمانية قرون: عبدالله بن عبد الرحمن بن صالح البسام، دار العاصمة،

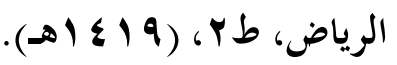

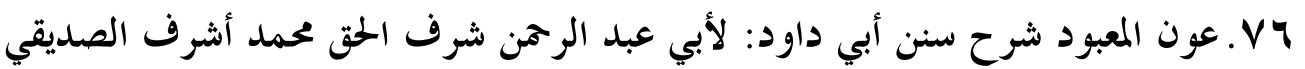

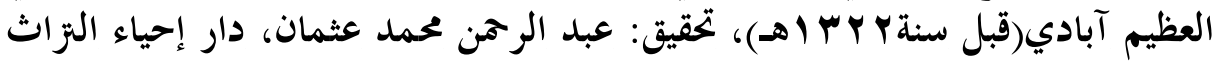

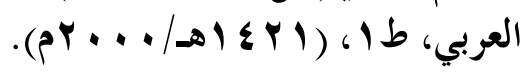

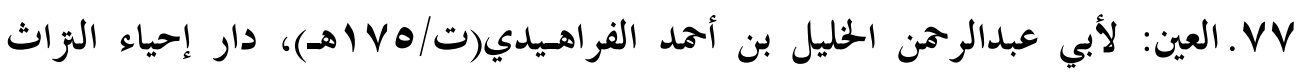

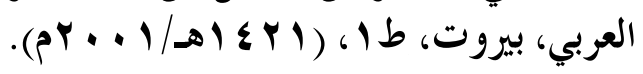

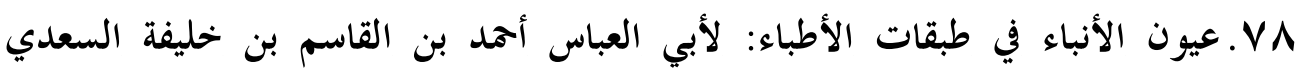

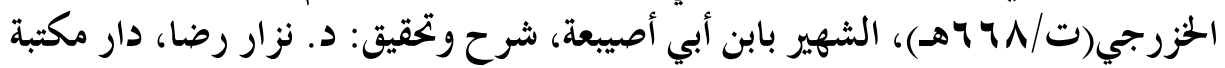

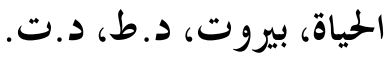

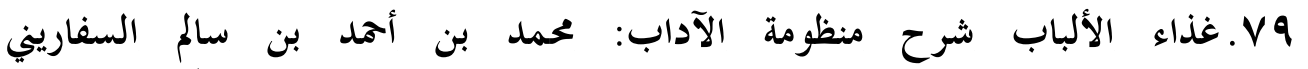

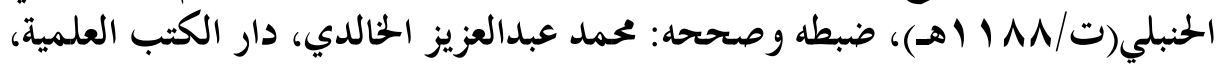

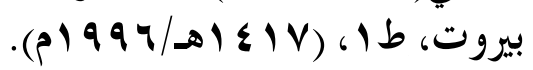

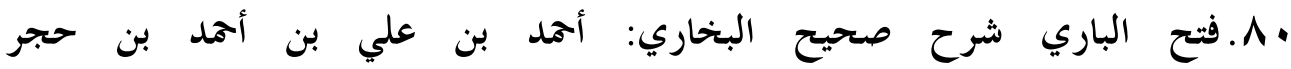

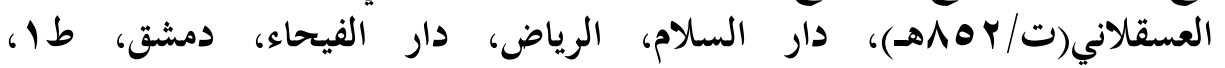

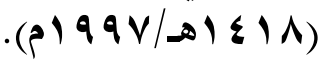

اي. الفروع: شثم الدين عبدالله بن محمد بن مفلح المقدسي، الشهير بابن مفلح 


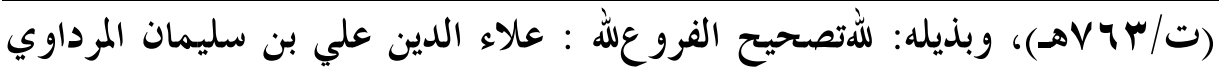

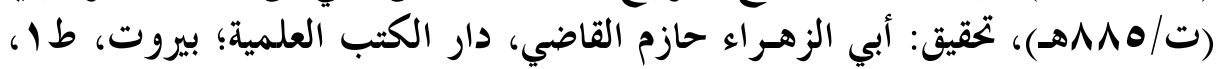

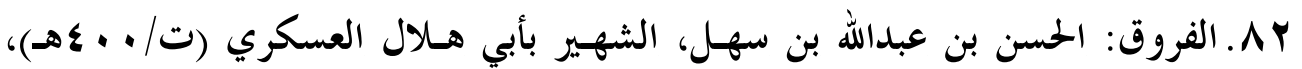

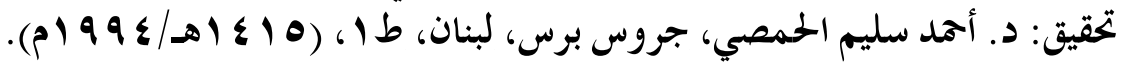

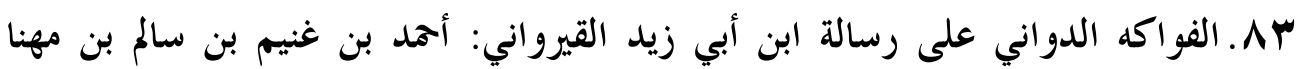

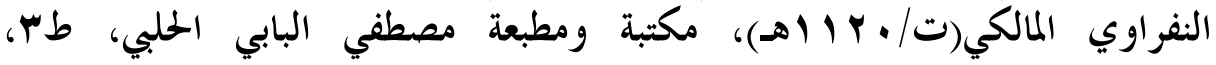

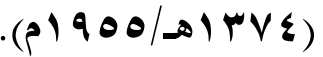

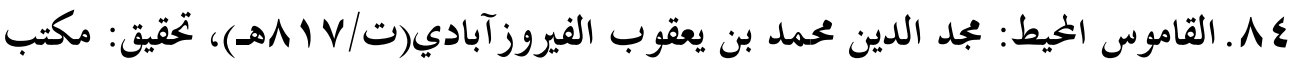

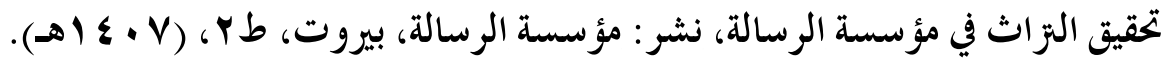

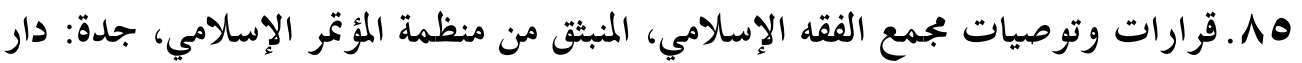

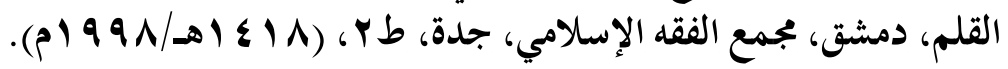

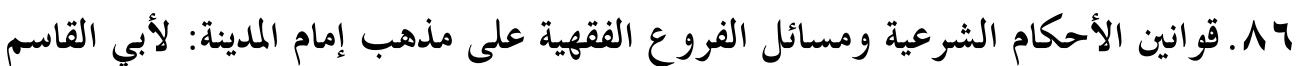

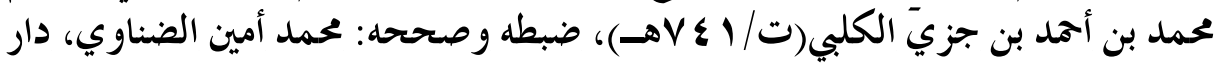

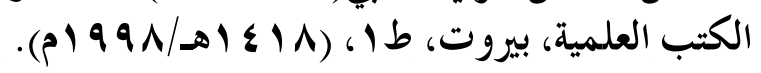

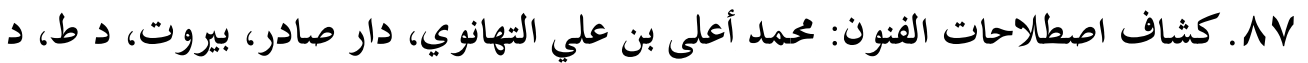

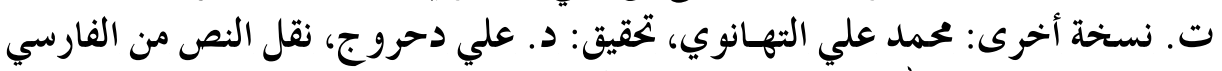

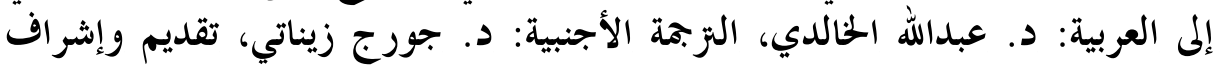

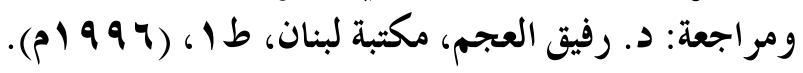

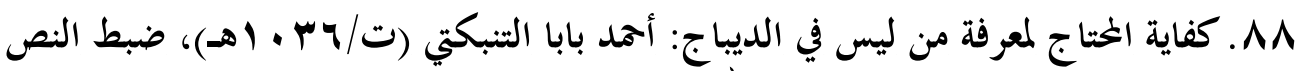

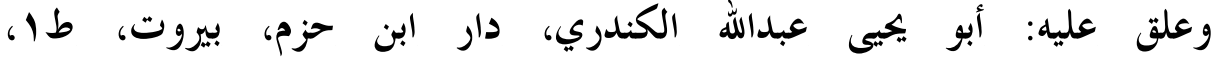

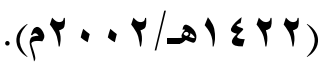

19. الكليات، معجم في المصطلحات والفروق اللغوية: لأبي البقاء أيوب بن موسى الحسيني

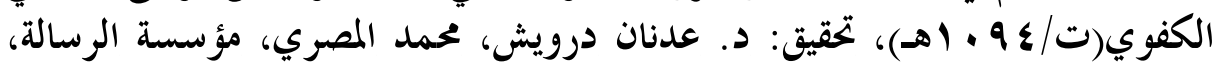

$$
\text { ط ط ( }
$$

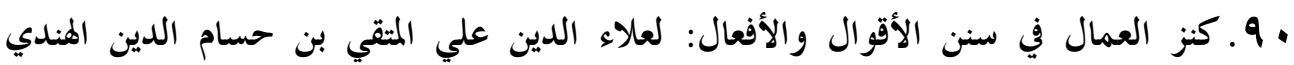

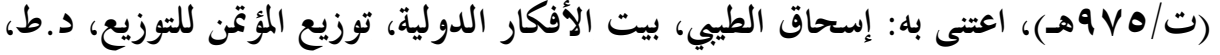




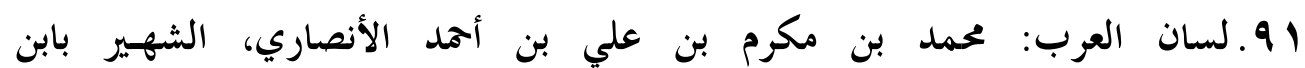

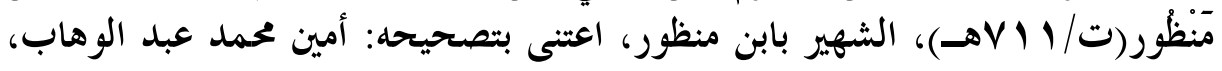

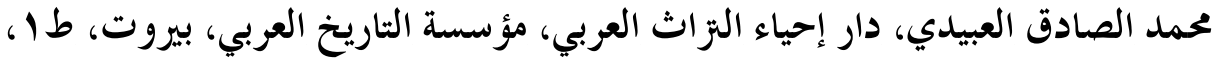

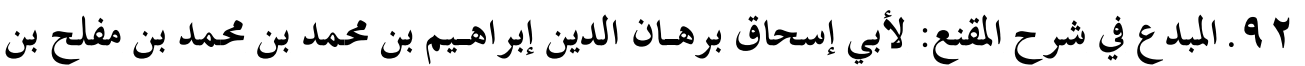

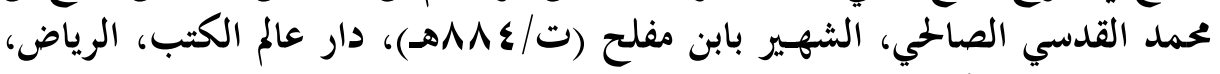

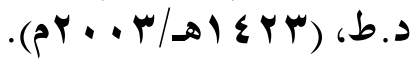

ب9. المبسوط: محمد بن أحد بن أبي سهل السرخسي الحنفي(ت/ • 9 \&هـ)، دار المعرفة،

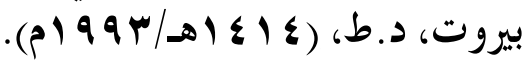

צ 9 ـ مجمع الزوائد ومنبع الفوائد: نور الدين أبو الحسن علي بن أبي بكر بن سليمان الهـيثمي

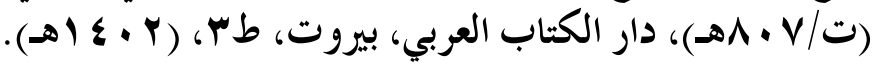

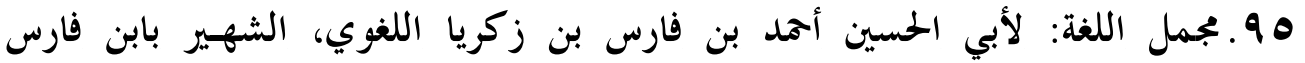

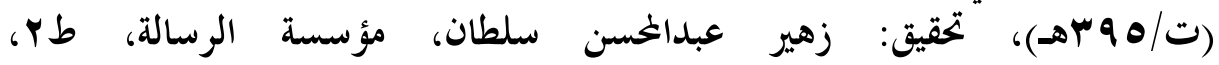

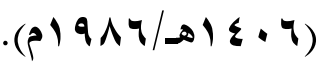

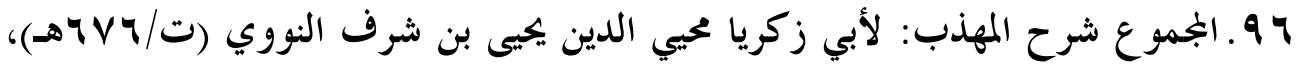

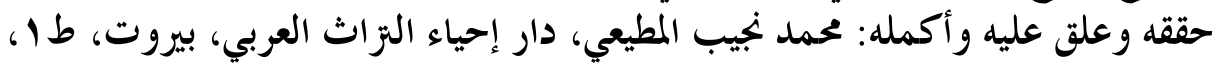

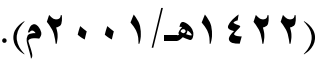

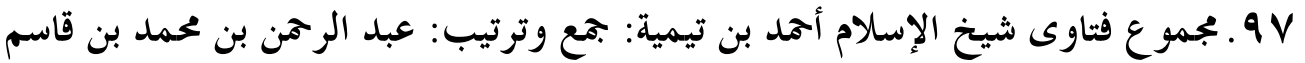

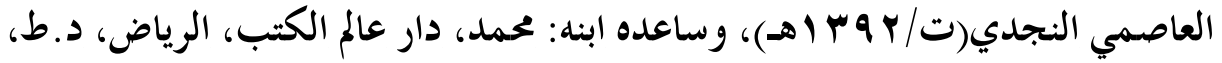

ه 9 مجموعة الأنظمة السعودية: هـيئة الحبراء بمجلس الوزراء، المملكة العربية السعودية،

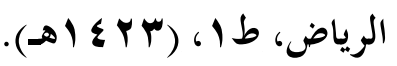

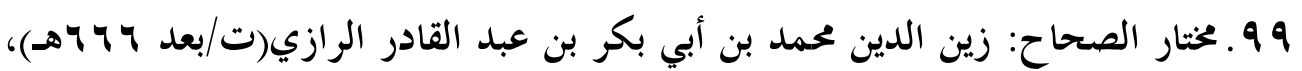

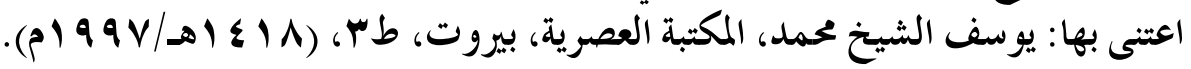

• . . . المختارات في الطب: مهذب الدين علي بن أحمد بن هبل البغدادي( • (ا7هـ)، دائرة

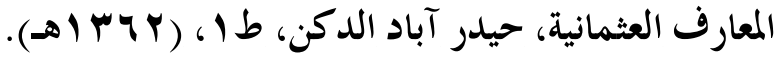


1 ـ ا ـ المدخل الفقهي العام: مصطفى أحد الزرقا(ت/ • بع (هـ)، دار القلم، دمشق، طا،

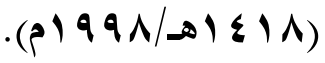

r • 1 ـ المدخل إلى تنمية الأعمال بتحسين النيات والتببيه على بعض البدع والعوائد التي

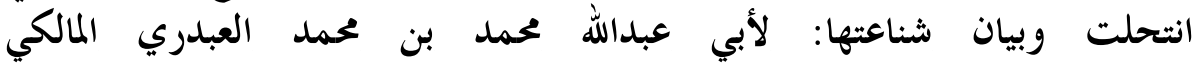

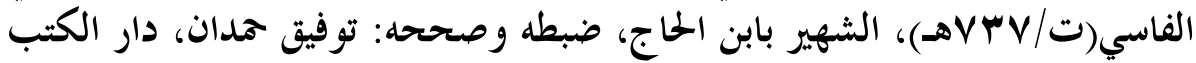

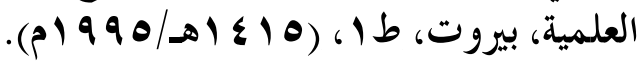

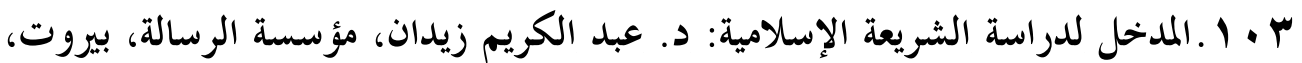

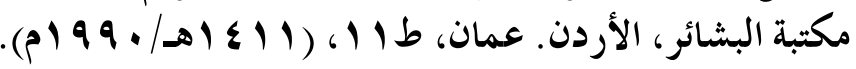

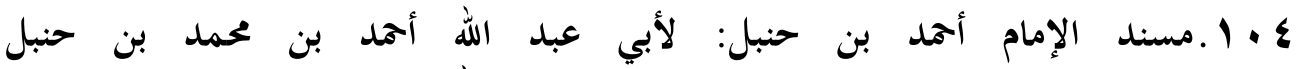

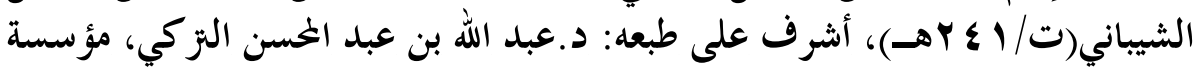

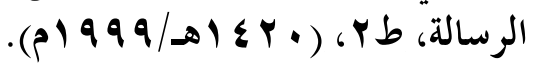

ه • 1 ـ المسؤولية الجزائية للأطباء عن إفشاء السِّ المهني: موفق علي عبيد، مكتبة دار الثقافة،

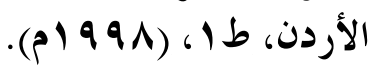

ج ـ 1 ـ المسؤولية الجنائية للطبيب عن إفشاء سر المهنةللهدراسة مقارنةلله: د. أسامه عبدالله قايد،

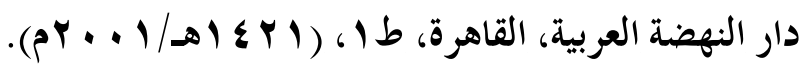

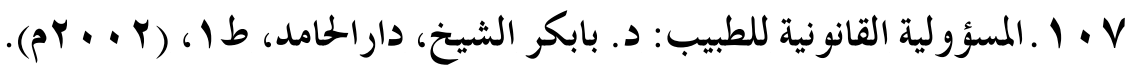

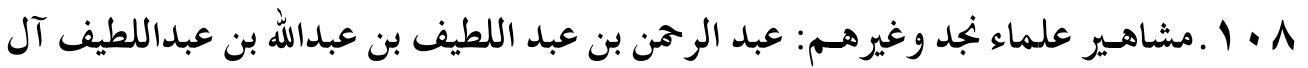

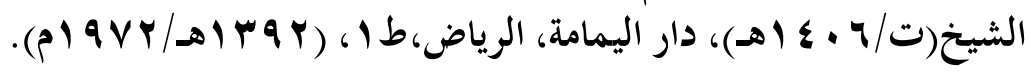

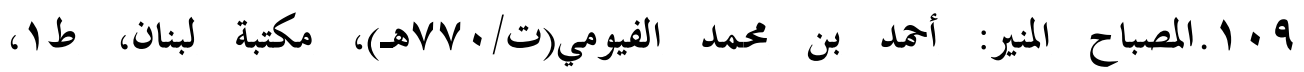

$$
\text { .( () } 9 \wedge V /-01 \varepsilon \cdot V)
$$

• 1 ـ مطلع الفجر في فقه الزجر بالهـر، ومعه: "بيان منهج السلف الصالح في معاملة أهـل البدع والأهـواء" وبذيله: "مذهـب شيخ الإسلام ابن تيمية في الهـر" : تأليف: سليم

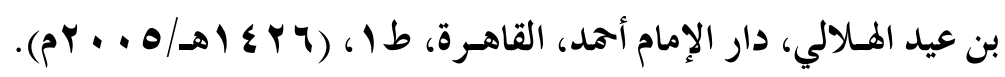

111 ـ معجم المصطلحات والألفاظ الفقهية: د. محمود عبد الرحن عبد المنعم، دار الفضيلة،

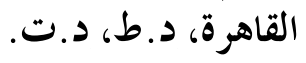




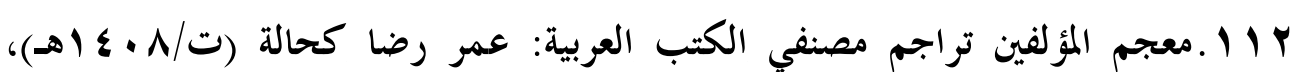

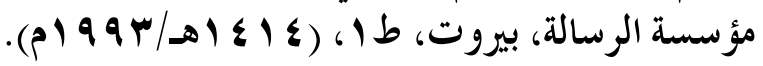

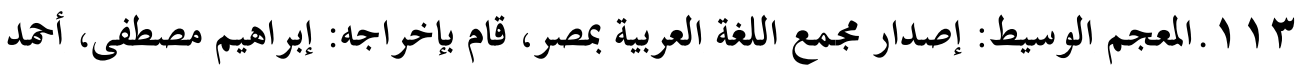

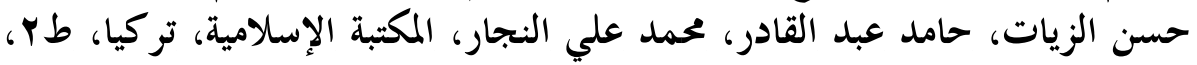

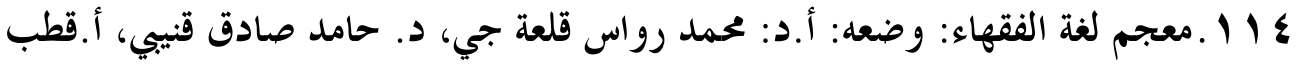

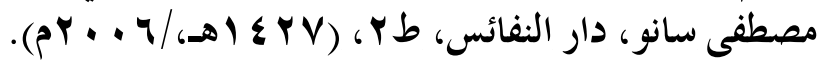

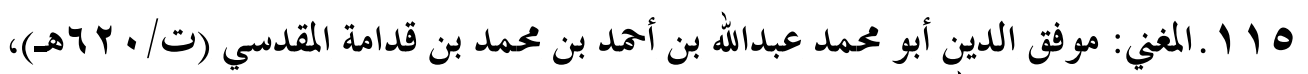

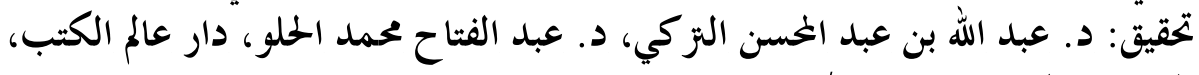

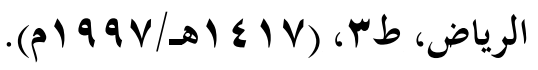

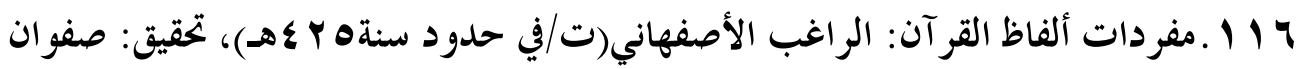

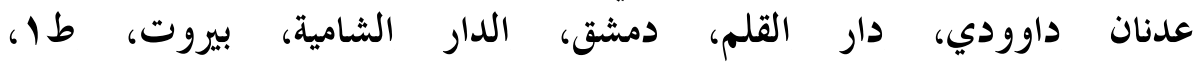

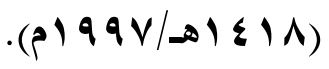

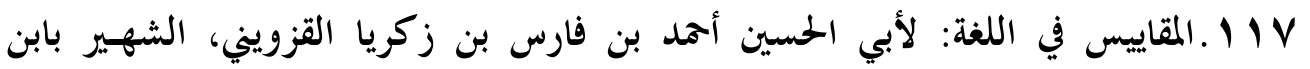

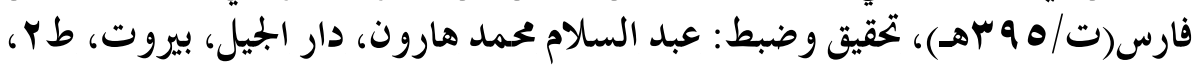

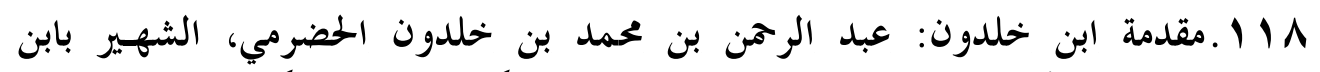

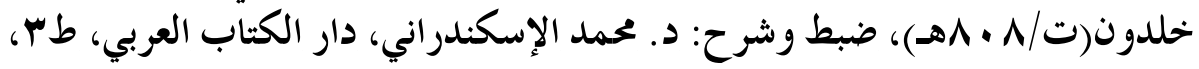

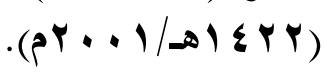

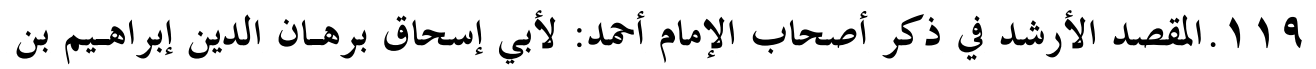

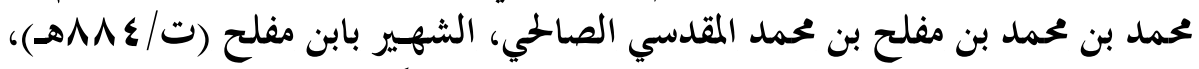

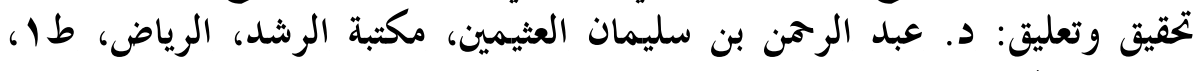

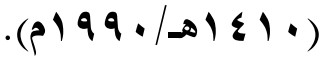

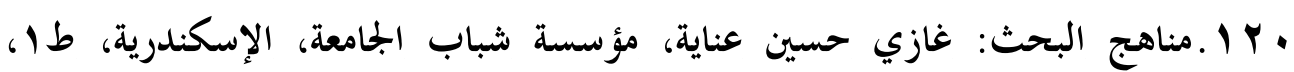

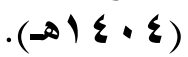

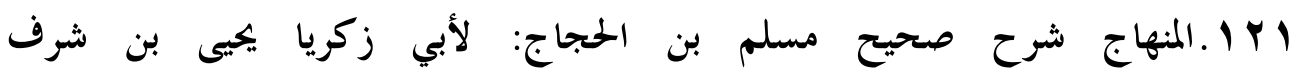

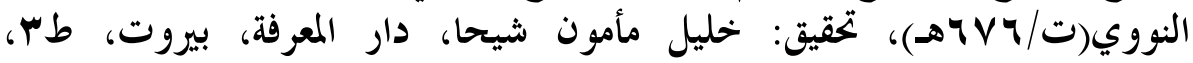


ץ Y ا ـ الموجز في تاريخ الطب عند العرب: د. رحاب خضر عكاوي، دار المناهل، بيروت،

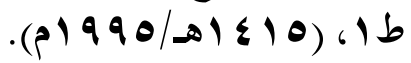

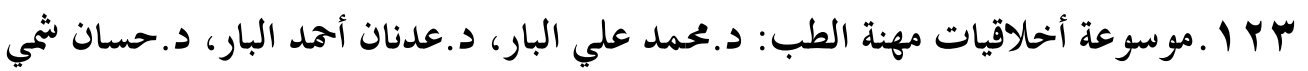

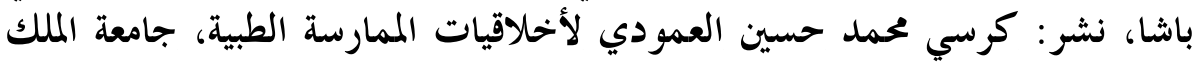

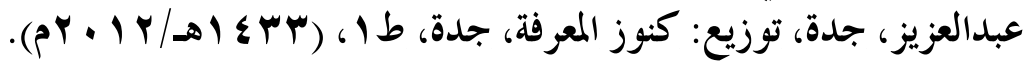

ع I ا.لموسوعة الطبية الفقهية: د. أحمد محمد كنعان، دار النفائس، بيروت، طاه

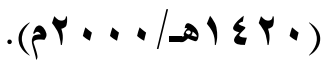

ه Y ا ـ الموسوعة الفقهية: إصدار: وزارة الأوقاف والشئون الإسلامية، طباعة ذات السلاسل،

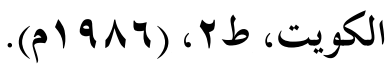

צ Y I ـ موسوعة القواعد الفقهية: د. محمد صدقي بن أحمد بن محمد البورنو، مؤسسة الرسالة،

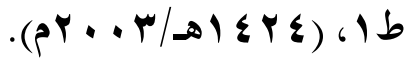

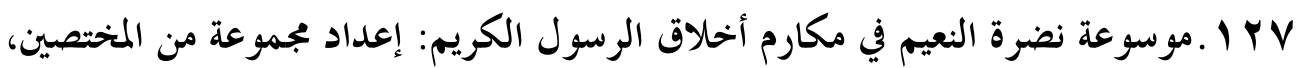

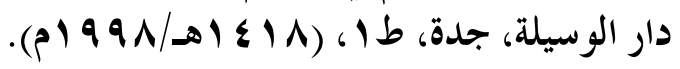

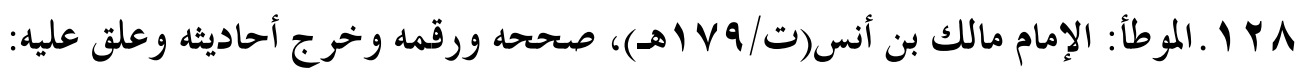

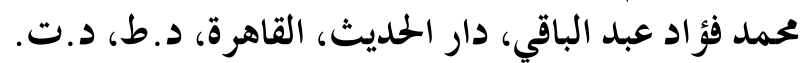

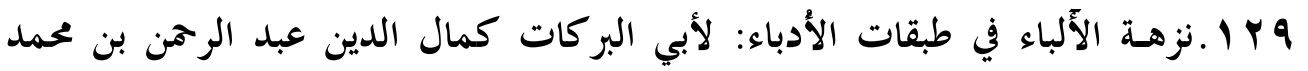

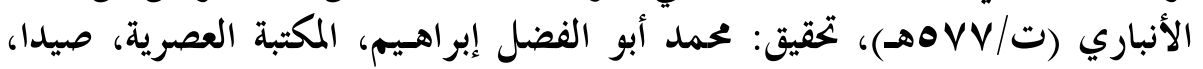

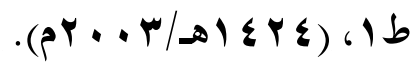

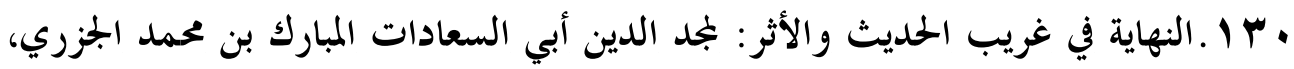

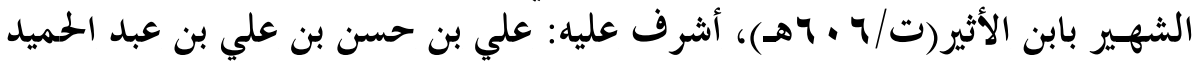

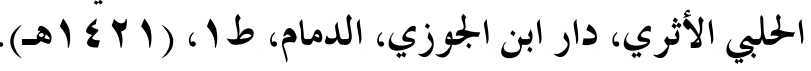

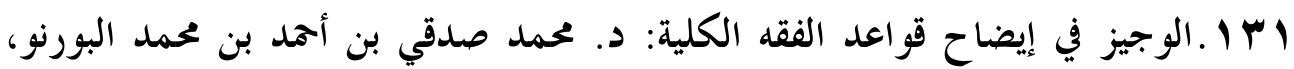

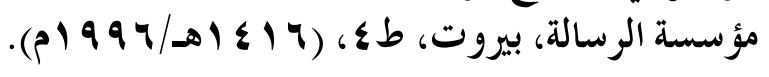

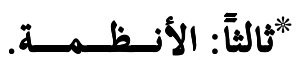
ץ ا ـ أخلاقيات مهنة الطب: إصدار الهيئة السعودية للتخصصات الطبية، موقع الهيئة 
السعو دية للتخصصات الطبية على شبكة الإنتزنت: WWW.scfhs.orq.

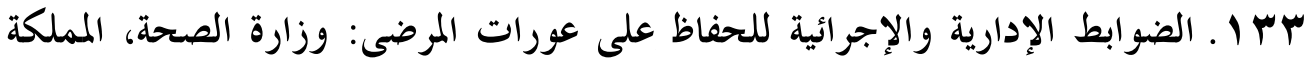

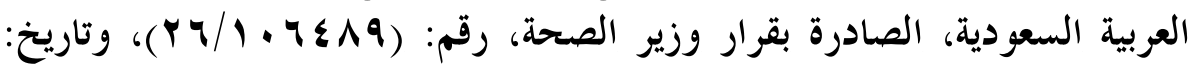

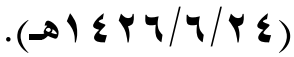

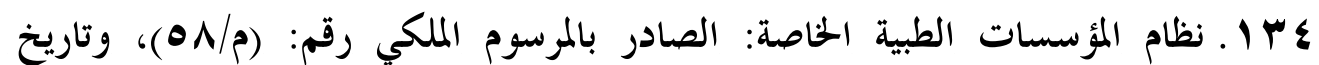

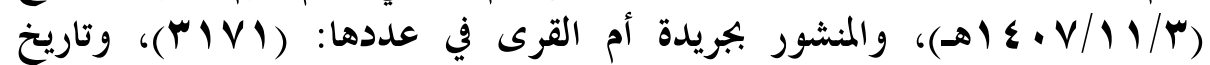

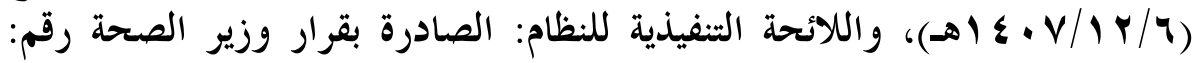

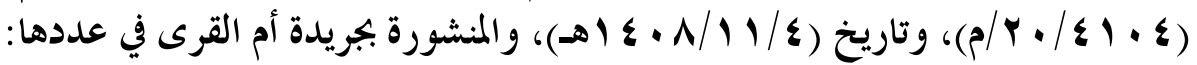
(1)

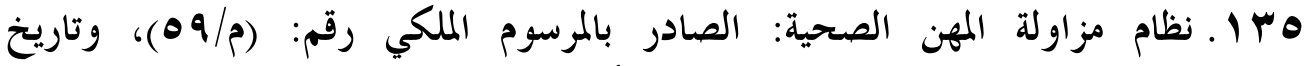

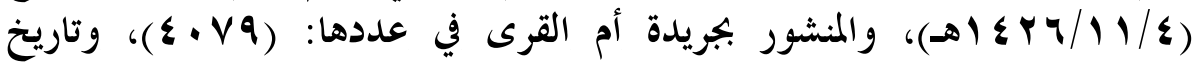

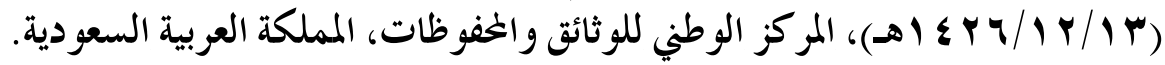

رابعاً: الدوريات.

צM ا . جريدة أم القرى: الجريدة الرسمية للمملكة العربية السعودية، تصدر بمكة المكرمة،

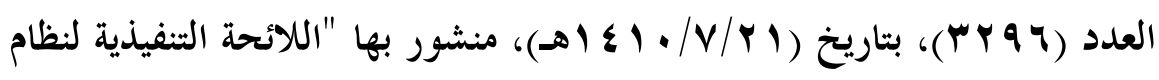
مزاولة مهنة الطب البشري وطب الأسنان".

ITV

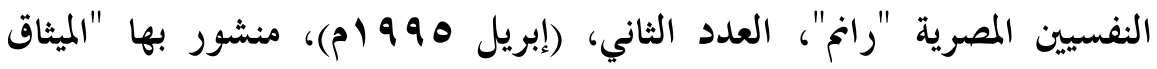
الأخلاقي للمشتغلين بعلم النفس في مصر" المرئ

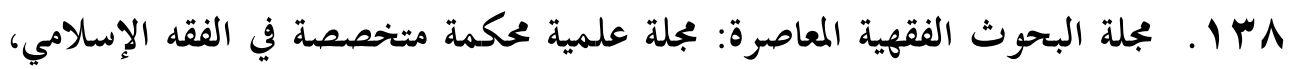

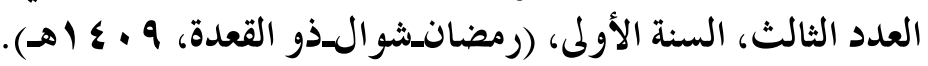

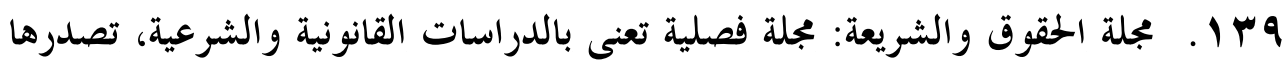

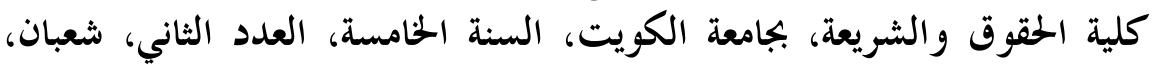


• ع ا ـ مجلة القضائية: مجلة علمية محكمة تعنى بنشر البحوث و الدراسات القضائية المعاصرة،

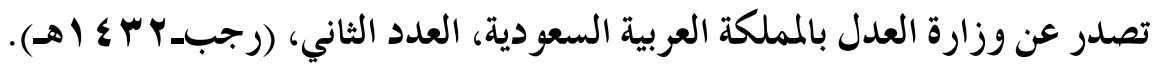

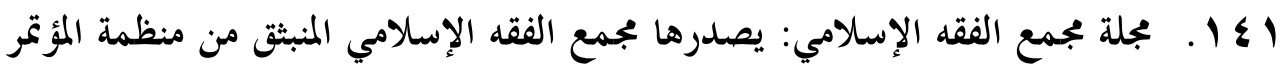

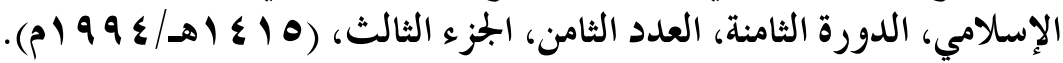

$$
\begin{aligned}
& \text { *خامساً: المواقع الالكتوونية. } \\
& \text { 1- الجمعية السعودية لطب الأسرة والجتمع: }
\end{aligned}
$$

WWW.ssfcm.org/ssfcm_ar

$$
\text { r - منظمة الصحة العالميتـالمكتب الإقليمي بالشرق الأوسط: }
$$

www.emro.who.int/Arabic

$$
\text { ץ- الهيئة السعودية للتخصصات الطبية على شبكة الإنتزنت: }
$$

WwW.scfhs.orq 